DOE/RL-93-51

Revision 0

UC No. 630

\title{
Limited Field Investigation Report for the 100-HR-1 Operable Unit
}

Date Published

August 1994

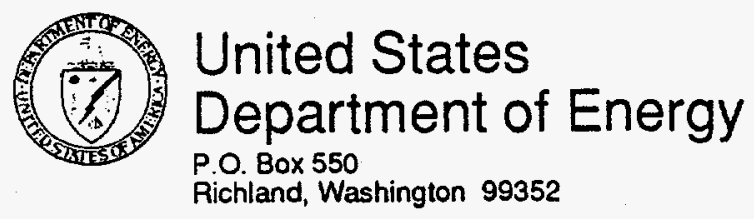




\section{DISCLAIMER}

This report was prepared as an account of work sponsored by an agency of the United States Government. Neither the United States Government nor any agency thereof, nor any of their employees, make any warranty, express or implied, or assumes any legal liability or responsibility for the accuracy, completeness, or usefulness of any information, apparatus, product, or process disclosed, or represents that its use would not infringe privately owned rights. Reference herein to any specific commercial product, process, or service by trade name, trademark, manufacturer, or otherwise does not necessarily constitute or imply its endorsement, recommendation, or favoring by the United States Government or any agency thereof. The views and opinions of authors expressed herein do not necessarily state or reflect those of the United States Government or any agency thereof. 


\section{DISCLAIMER}

Portions of this document may be illegible in electronic image products. Images are produced from the best available original document. 
DOE/RL-93-51, Rev. 0

\section{EXECUTIVE SUMMARY}

\section{BACKGROUND}

This limited field investigation (LFI) report summarizes the data collection and analysis activities conducted during the 100-HR-1 Source Operable Unit LFI and the associated qualitative risk assessment (QRA) (WHC 1993a), and makes recommendations on the continued candidacy of high-priority sites for interim remedial measures (IRM). The results and recommendations presented in this report are generally independent of future land use scenarios. This report is unique in that it is based on Hanford-specific agreements discussed in the Hanford Federal Facility Agreement and Consent Order (Tri-Party Agreement, Ecology et al. 1990), the Hanford Past-Practice Strategy (HPPS), the Hanford Site Baseline Risk Assessment Methodology (HSBRAM), and the RCRA Facility Investigation/Corrective Measures Study Work Plan for the 100-HR-1 Operable Unit, Hanford Site, Richland, Washington (DOE-RL 1992a) and must be viewed in this context. The HPPS, described and justified in The Hanford Federal Facility Agreement and Consent Order Change Package and dated May 16, 1991 (Ecology et al. 1991), emphasizes initiating and completing waste site cleanup through interim actions.

A LFI Report is required, in accordance with the HPPS, when waste sites are to be considered for IRMs. The LFI is an integral part of the remedial investigation/feasibility study (RI/FS) or Resource Conservation and Recovery Act (RCRA) facility investigation/ corrective measures study (RFI/CMS) process and functions as a focused RI or RFI for selection of IRMs. The purpose of the report is to identify those sites that are recommended to remain as candidates for IRMs, provide a preliminary summary of site characterization studies, refine the conceptual model as needed, identify contaminant- and location-specific applicable or relevant and appropriate requirements (ARAR), and provide a qualitative assessment of the risks associated with the sites. This assessment includes consideration of whether contaminant concentrations pose an unacceptable risk that warrants action through IRMs. An IRM is defined by the HPPS in broad terms and is not restricted to limited- or near-term actions. Interim remedial measures are intended to achieve remedies that are likely to lead to a final Record of Decision. The final decision to conduct an IRM will rely on many factors including risk, ARARs, future land use, point of compliance, time of compliance, a bias-for-action, and the threat to human health and the environment.

The unit managers assigned all known and suspected areas of contamination in the 100-HR-1 Operable Unit either a high- or low-priority, as listed in Table ES-1. The classification of sites was based on the collective knowledge of the three parties and information contained in existing work plans. The site classification decisions were made during joint meetings with the three parties and are documented by meeting minutes that are part of the administrative record. Sites classified as high-priority pose risk(s) through one or more pathways sufficient to recommend a streamlined action via an IRM. Low-priority sites do not pose risks sufficient to recommend streamlining. 
The 100-HR-1 Source Operable Unit is one of two source operable units associated with the 100-H Area at the Hanford Site. The 100-HR-1 and 100-HR-2 Source Operable Units address contaminant sources while the 100-HR-3 Groundwater Operable Unit addresses contamination present in the underlying groundwater. The 100-HR-1 Source Operable Unit encompasses approximately 100 acres ( 40.5 hectares) and is located immediately adjacent to the Columbia River shoreline. The operable unit contains waste units associated with the original plant facilities constructed to support the $H$ Reactor. The area also contains evaporation basins which received liquid process wastes and nonroutine deposits of chemical wastes from the 300 Area, where fuel elements for the $\mathbf{N}$ Reactor were produced. These solar evaporation basins received wastes from 1973 through 1985 and are therefore under the jurisdiction of RCRA interim status treatment, storage, and disposal requirements. Currently there are no active facilities or operations within the $100-\mathrm{HR}-1$ Source Operable Unit.

The 100-HR-1 Source Operable Unit LFI was performed to provide additional data needed to support a decision on the appropriateness of continuing along the HPPS IRM pathway. The LFI included data compilation, non-intrusive investigations, intrusive investigations at five high-priority sites, and data evaluation. It also summarized recent results of the 100 Area aggregate studies.

\section{INVESTIGATION RESULTS}

Intrusive vadose zone boreholes were drilled at five sites. Soil samples were collected from each borehole and submitted for laboratory analysis. Boreholes were surveyed for radiological contamination using downhole geophysical techniques to further delineate the locations and levels of contaminants. Materials removed from the boreholes were screened in the field for volatile organic compounds and radionuclides to assist in selection of sample intervals. Analytical data were validated. All data associated with the LFI were evaluated.

Five sites were investigated by vadose zone boreholes: $116-\mathrm{H}-1,116-\mathrm{H}-2,116-\mathrm{H}-3$, 116-H-7, and 116-H-9. Radiological contamination is the primary concern, as confirmed through this study. Metals contamination was found at the 116-H-1 process effluent disposal trench and the 116-H-7 process effluent retention basin. The maxinum concentrations of metals in the $116-\mathrm{H}-1$ samples were: As $-37.9 \mathrm{mg} / \mathrm{kg}, \mathrm{Cr}-29.6 \mathrm{mg} / \mathrm{kg}$, and $\mathrm{Pb}-187$ $\mathrm{mg} / \mathrm{kg}$. The maximum concentrations of metals in the $116-\mathrm{H}-7$ samples were: As -47 $\mathrm{mg} / \mathrm{kg}$ and $\mathrm{Pb}-540 \mathrm{mg} / \mathrm{kg}$. Semi-volatile organic compounds were detected in concentrations below the potential soil ARARs, which are Washington State Model Toxics Control Act (MTCA) cleanup regulation Method B concentrations. Volatile organic compounds, while detected, were generally low in cuncentration or likely laboratory contamination. The historical data (Dorian and Richards 1978) associated with the sites where LFI boreholes were drilled were partially confirmed in that the majority of the contaminants presented in the historical data were also detected during the intrusive investigations. However, the detected concentrations of those contaminants were not consistent with the concentrations reported in the historical data. The concentrations reported in the historical data were generally one to two orders of magnitude higher than the 
concentrations detected during the recent intrusive investigations. The remaining high-priority sites in the 100-HR-1 Source Operable Unit were evaluated using data from analogous sites in the 100 Areas or historical data. No 100-HR-1 sites showed contamination that would warrant an expedited response action.

Three low-priority sites were also investigated as part of the LFI. The sites consisted of two septic tanks (1607-H-2 and 1607-H-4) and the electrical facilities within the $100 \mathrm{H}$ Area. Heavy metal contaminants and man-made radionuclides were found at both septic tank sites, with the $1607-\mathrm{H}-2$ site having the higher concentrations. It is recommended that the 1607-H-2 septic tank site be reviewed for possible reclassification from a low-priority site to a high-priority site due to the high concentrations of contaminants detected. Polychlorinated biphenyl (PCB) sampling results from surface-soil samples taken at the electrical facilities showed small concentrations of PCBs in five of the eight samples taken. The sample locations were determined by visual inspection of the area and samples were only taken where transformer oils were suspected to have spilled.

\section{QUALITATIVE RISK ASSESSMENT}

A QRA was performed for the high priority sites. Conservative assumptions such as highest reported contaminant levels from either the LFI or historical data base were utilized. The QRA provides estimates of human health risks assuming either low-frequency or high-frequency use and includes considerations such as the attenuation of external dose provided by layers of clean gravel fill that overlie many sites. The QRA identifies the major human health risk to be external exposure from the radionuclides Co-60, Cs-137, Eu-152, and Eu-154. The QRA also provides environmental hazard quotient (EHQ) risk estimates for many of the 100-HR-1 high-priority sites.

\section{IRM RECOMMENDATIONS}

The 100-HR-1 high-priority sites were evaluated using the following criteria to identify sites recommended to continue as IRM candidates; a detailed discussion of the criteria is provided in Section 5.2 of this report:

- The QRA provides risk estimates for human health and the EHQ ratings. Sites with high or medium risks to human health for the low-frequency use scenario are recommended to continue as IRM candidates. High risk corresponds to an incremental cancer risk (ICR) greater than $1 \mathrm{E}-02$. Medium risk corresponds to an ICR between 1E-04 and 1E-02. Low risk corresponds to an ICR between $1 \mathrm{E}-06$ and 1E-04. Very low risk corresponds to an ICR of less than 1E-06. Sites with an EHQ rating $>1$ are also recommended to continue as IRM candidates.

- If contaminants at the waste site exceed a chemical-specific ARAR, that site is recommended to continue as an IRM candidate. The Washington State MTCA 
Method B concentrations are potential ARARs for soil contamination, as discussed in Section 3.9 of this report and in the 100 Area Feasibility Study, Phases 1 and 2 (DOE-RL 1992c). Model Toxics Control Act Method B regulatory limits for soil contaminant concentrations are utilized because they are the standard method and are conservative.

- If LFI results indicate that a site is a current source of groundwater contamination then the site is recommended to continue as an IRM candidate.

- The conceptual model for the waste site includes sources of contamination, types of contaminants, affected media, known and potential routes of migration, known or potential human and environmental receptors, and the general understanding of the site structure/process. If the conceptual model of the site is found to be incomplete, collection of data needed to complete the model through limited field sampling is recommended. Sites with incomplete conceptual models are recommended to continue as IRM candidates.

- The potential for the contaminants at a site to be reduced by natural attenuation, e.g., radioactive decay by the year 2018 , may be a consideration for sites where the excess risk is caused solely by external exposure from radionuclides with half lives of $<30$ years. This is not a consideration for sites where multiple exposure pathways drive the risk.

Table ES-2 presents the evaluation of the high-priority waste sites using the above criteria, and the previous site-specific IRM recommendations. The following sites are recommended to continue as IRM candidates:

- 116-H-1 process effluent disposal trench, 116- $\mathrm{H}-7$ process effluent retention basin, 116-H-5 process effluent outfall structure, and the process effluent pipeline sludge and soil. Additionally, the 116- $\mathrm{H}-2$ effluent disposal trench, 132- $\mathrm{H}-3$ effluent pumping station, 132- $\mathrm{H}-2$ exhaust air filter building, 132- $\mathrm{H}-1$ reactor exhaust stack, and 116- $\mathrm{H}-4$ pluto crib sites are recommended to continue to be IRM candidates and are recommended to be considered as solid waste burial grounds for future studies.

The 116-H-2 effluent disposal trench, 132-H-3 effluent pumping station, 132-H-2 exhaust air filter building, 132- $\mathrm{H}-1$ reactor exhaust stack, and 116- $\mathrm{H}-4$ pluto crib sites are recommended to be addressed as solid waste burial grounds.

The 116-H-9 confinement seal pit drainage crib, 116-H-3 dummy decontamination French drain, and 116-H=7 sludge burial trench sites are not recommended for IRMs, since risks, contamination, and impact to groundwater are all low. Action at these sites may be deferred until final remedy selection. 
DOE/RL-93-51, Rev. 0

Table ES-1 100-HR-1 Operable Unit High-Priority Sites and Low-Priority Sites

\begin{tabular}{|c|c|}
\hline HIGH-PRIORITY SITES & LOW-PRIORITY SITES \\
\hline $\begin{array}{l}\text { 116-H-1 Process Effluent Disposal Trench } \\
\text { 116-H-2 Effluent Disposal Trench } \\
\text { 116-H-3 Dummy Decontamination French } \\
\text { Drain } \\
\text { 116-H-7 Process Effluent Retention Basinª } \\
\text { 116-H-9 Confinement Seal Pit Drainage } \\
\text { Crib } \\
\text { 116-H-5 Process Effluent Outfall Structure } \\
\text { Process Effluent Pipelines (Sludge) } \\
\text { Process Effluent Pipelines (Soil) } \\
\text { 116-H-7 Sludge Burial Trench } \\
\text { 132-H-3 Effluent Pumping Station } \\
\text { 132-H-2 Exhaust Air Filter Building } \\
\text { 132-H-1 Reactor Exhaust Stack } \\
\text { 116-H-4 Pluto Crib } \\
\text { 116-H-6 Solar Evaporation Basins }\end{array}$ & $\begin{array}{l}\text { 1607-H-2 Septic System } \\
\text { 1607-H-4 Septic System } \\
\text { Electrical Facilities }\end{array}$ \\
\hline \multicolumn{2}{|c|}{$\begin{array}{l}\mathrm{a}=\text { Soil sampling conducted as part of the Limited Field Investigation } \\
\mathrm{b}=\text { Additional data used from analogous site } \\
c=\text { Remote sensing performed on section of process effluent pipeline } \\
d=116-\mathrm{H}-6 \text { Solar Evaporation Basins are to be considered under RCRA Interim Status } \\
\text { and are not further addressed in this document }\end{array}$} \\
\hline
\end{tabular}

Source: DOE-RL, 1992a 


\begin{tabular}{|c|c|c|c|c|c|c|c|}
\hline \multirow[t]{2}{*}{ Waste Site } & \multicolumn{2}{|c|}{$\begin{array}{c}\text { Qualitative Risk } \\
\text { Estimation }\end{array}$} & \multirow[t]{2}{*}{$\begin{array}{l}\text { Conceptual } \\
\text { Model }\end{array}$} & \multirow[t]{2}{*}{$\begin{array}{l}\text { Exceeds } \\
\text { ARAR }\end{array}$} & \multirow{2}{*}{$\begin{array}{c}\text { Probable } \\
\text { Current } \\
\text { Impact on } \\
\text { Ground water }\end{array}$} & \multirow{2}{*}{$\begin{array}{c}\text { Potential } \\
\text { for Natural } \\
\text { Attenuation } \\
\text { by } 2018\end{array}$} & \multirow{2}{*}{$\begin{array}{c}\text { IRM } \\
\text { Candidate } \\
\text { yes/no }\end{array}$} \\
\hline & $\begin{array}{l}\text { Low- } \\
\text { frequency } \\
\text { scenario }\end{array}$ & $\begin{array}{r}E H Q \\
>1\end{array}$ & & & & & \\
\hline 116-H-1 Process Effluent Disposal Trench & Medium & Yos & Adequate & Yos & Yos & No & Yes \\
\hline 116-H-2 Effluent Disposal Trench & Low & Yes & Incomplete* & No & No & No & Yes* \\
\hline 116-H-3 Dummy Decontamination French Drain & Low & No & Adequate & No & No & Yes & No \\
\hline 116-H-7 Process Effluent Retention Basin & High & Yes & Adequate & Yes & Yes. & No & Yes \\
\hline 116-H-9 Confinement Seal Pit Drainage Crib & Low & No & Adequate & No & No & Yes & No \\
\hline 116-H-5 Process Effluent Outfall Structure & Medium &.. & Adequate & No & No & No & Yes \\
\hline Process Effluent Pipelines (Soil) & Very Low & No & Adequate & No & Yes & No & Yes \\
\hline Process Effluent Pipelines (Sludge) & High & No & Adequate & No & Yos & No & Yes \\
\hline 116-H-7 Sludge Burial Trench & Very Low &.- & Adequate & No & No & No & No \\
\hline 132-H-3 Effluent Pumping Station & Low & -- & Adequate & Unknown & Unknown & Unknown & Yes \\
\hline 132-H-2 Exhaust Air Filter Building ${ }^{b}$ & Low & .. & Adequate & Unknown & No & Unknown & Yes \\
\hline 132-H-1 Reactor Exhaust Stack & Low & - & Adequate & Unknown & No & Unknown & Yes \\
\hline 116-H-4 Pluto Crib & Low & - & Adequate & Unknown & No & Unknown & Yes \\
\hline \multicolumn{8}{|c|}{$\begin{array}{l}\text { EHQ = Environmental Hazard Quotient calculated by the qualitative ecological risk assessment (WHC 1993a) } \\
=\text { = Not rated by the qualitative ecological risk assessment } \\
=\text { Data needed concerning nature and vertical extent of contamination, site remains an IRM candidate until data are available. } \\
=\text { Conceptual model is considered incomplete due to discrepencies between the LFI data and the historical data. The LFI data indicates little or no } \\
\text { contemination which contradicts with the historical data. Additional investigation may be necessary. } \\
\text { ARAR = Applicable or Relevant and Appropriate Regulation, specifically the Washington state Model Toxics Control Act Method B concentration values for soils } \\
\text { (DOE-RL, } 1992 \text { a) } \\
=\text { The } 132-\mathrm{H}-2 \text { exhaust air filter building was built on the site of the excavated } 116-\mathrm{H}-4 \text { pluto crib. These two sites should be remediated simultaneously. } \\
\text { Shaded areas indicate driving factors keeping site as IRM candidate. }\end{array}$} \\
\hline
\end{tabular}




\section{ACRONYMS}

$\begin{array}{ll}\text { ARAR } & \text { applicable or relevant and appropriate requirements } \\ \text { ASTM } & \text { American Society for Testing and Materials } \\ \text { CERCLA } & \text { Comprehensive Environmental Response, Compensation, and Liability Act } \\ \text { CLP } & \text { Contract Laboratory Program } \\ \text { COPC } & \text { contaminant(s) of potential concern } \\ \text { CRDL } & \text { contract required detection limit } \\ \text { CRQL } & \text { contract required quantitation limit } \\ \text { DOE } & \text { U.S. Department of Energy } \\ \text { DOE-RL } & \text { U.S. Department of Energy, Richland Operations Office } \\ \text { EII } & \text { Environmental Investigation Instruction } \\ \text { EHQ } & \text { Environmental Hazard Quotient } \\ \text { EPA } & \text { U.S. Environmental Protection Agency } \\ \text { ERA } & \text { expedited response action(s) } \\ \text { GPR } & \text { ground-penetrating radar } \\ \text { HEIS } & \text { Hanford Environmental Information System } \\ \text { HQ } & \text { hazard quotient } \\ \text { HSBRAM } & \text { Hanford Site Baseline Risk Assessment Methodology } \\ \text { HPPS } & \text { Hanford Past-Practice Strategy } \\ \text { ICR } & \text { incremental cancer risk } \\ \text { IRM } & \text { interim remedial measures } \\ \text { LFI } & \text { Limited Field Investigation } \\ \text { LOEL } & \text { lowest observable effect level } \\ \text { MTCA } & \text { Model Toxics Control Act } \\ \text { NOEL } & \text { no observable effect level } \\ \text { OVM } & \text { organic vapor monitor } \\ \text { PCB } & \text { polychlorinated biphenyl } \\ \text { PNA } & \text { polynuclear aromatics } \\ \text { QAPjP } & \text { quality assurance project plan } \\ \text { QRA } & \text { qualitative risk assessment } \\ \text { RCRA } & \text { Resource Conservation and Recovery Act } \\ \text { RFI/CMS } & \text { RCRA Facility Investigation/Corrective Measures Study } \\ \text { RI/FS } & \text { remedial investigation/feasibility study } \\ \text { ROD } & \text { Record of Decision } \\ \text { SVOC } & \text { semi-volatile organic compound } \\ \text { TAL } & \text { target analyte list } \\ \text { TBC } & \text { to-be-considered } \\ \text { TCL } & \text { target compound list } \\ \text { TSD } & \text { treatment, storage, and disposal } \\ \text { UTL } & \text { upper threshold limit } \\ \text { VOC } & \text { volatile organic compound } \\ \text { WHC } & \text { Westinghouse Hanford Company } \\ \text { WIDS } & \text { Waste Information Data System } \\ & \end{array}$


DOE/RL-93-51, Rev. 0 


\section{CONTENTS}

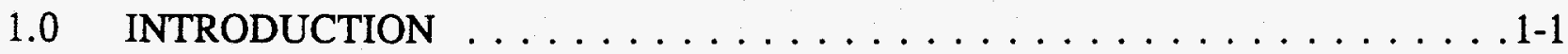

1.1 SITE BACKGROUND . . . . . . . . . . . . . . . 1-2

1.2 THE HANFORD SITE PAST-PRACTICE STRATEGY AND THE 100-HR-1 LFI . . . . . . . . . . . . . . . 1-3

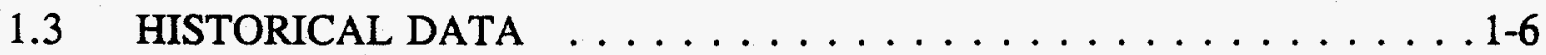

1.4100 AREA AGGREGATE STUDIES $\ldots \ldots \ldots \ldots \ldots \ldots \ldots$

1.4.1 Hanford Site Background . . . . . . . . . . . . . 1-7

1.4 .2 Ecological Analysis . . . . . . . . . . . . . . 1-8

1.4.3 Cultural Resources Review . . . . . . . . . . . 1-8

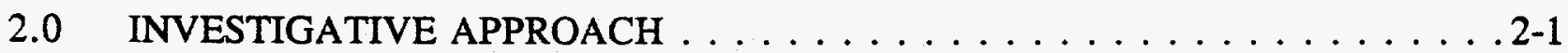

2.1 FIELD INVESTIGATION $\ldots \ldots \ldots \ldots \ldots \ldots \ldots \ldots \ldots \ldots \ldots \ldots \ldots .2-2$

2.1.1 Vadose Zone Boreholes . . . . . . . . . . . . . 2-2

2.1 .2 Low-Priority Sites . . . . . . . . . . . . 2-2

2.2 PHYSICAL PROPERTIES SAMPLING $\ldots \ldots \ldots \ldots \ldots \ldots .2-3$

2.3 GEOPHYSICAL DATA $\ldots \ldots \ldots \ldots \ldots \ldots \ldots \ldots \ldots \ldots . \ldots \ldots$

2.3.1 Vadose Zone Boreholes . . . . . . . . . . . . . . 2-3

2.3.2 Low-Priority Sites . . . . . . . . . . . . . 2-4

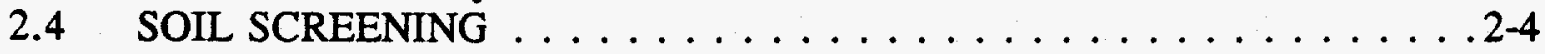

2.4.1 Vadose Zone Boreholes . . . . . . . . . . . . . . 2-4

2.4 .2 Low-Priority Sites . . . . . . . . . . . . . . . . 2-5

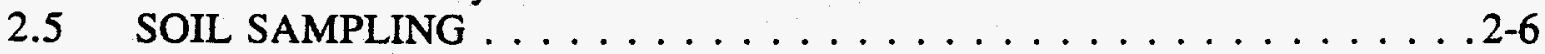

2.5.1 Vadose Zone Boreholes . . . . . . . . . . . . . . 2-6

2.5.2 Low-Priority Sites . . . . . . . . . . . . . 2-6

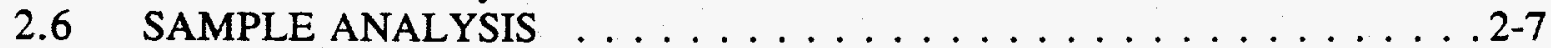

2.7 DATA VALIDATION $\ldots \ldots \ldots \ldots \ldots \ldots \ldots \ldots \ldots \ldots \ldots \ldots$

3.0 INVESTIGATION RESULTS AND CONCLUSIONS $\ldots \ldots \ldots \ldots \ldots \ldots$. . . . . .

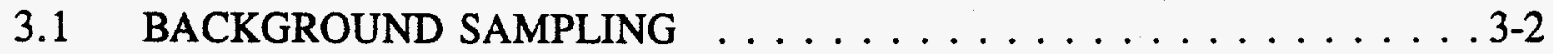

3.1.1 General Hanford Sitewide Background Data . . . . . . . . . . 3-2

3.1.2 Local Background Data . . . . . . . . . . . . . . . . 3-2

$3.2116-\mathrm{H}-1$ PROCESS EFFLUENT DISPOSAL TRENCH . . . . . . . . 3-2

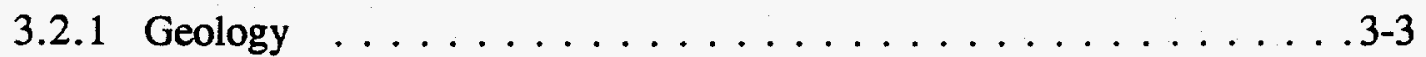

3.2.2 Soil Samples . . . . . . . . . . . . . . . . . . 3-3

3.2.3 Physical Properties Sample . . . . . . . . . . . . . . . 3-4

3.2 .4 Conclusions . . . . . . . . . . . . . . . . . 3-5

3.2.5 Groundwater Assessment . . . . . . . . . . . . 3-6

3.3 116-H-2 EFFLUENT DISPOSAL TRENCH $\ldots \ldots \ldots \ldots \ldots \ldots . \ldots .6 . \ldots$

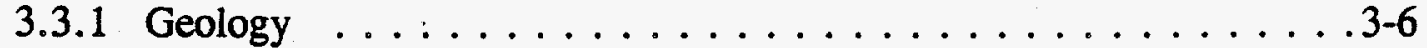

3.3.2 Soil Samples . . . . . . . . . . . . . . . . 3-7

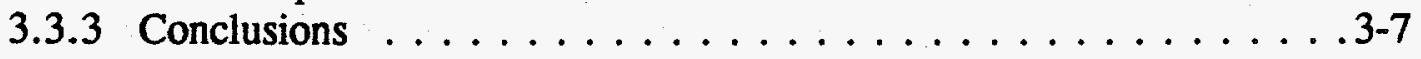

3.3.4 Groundwater Assessment $\ldots \ldots \ldots \ldots \ldots \ldots \ldots$. . . . . . . . 
DOE/RL-93-51, Rev. 0

CONTENTS (cont)

3.4 116-H-3 DUMMY DECONTAMINATION FRENCH DRAIN $\ldots \ldots .3-8$

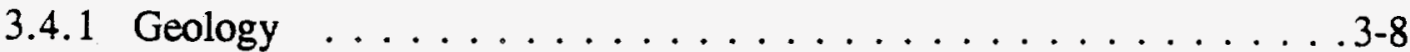

3.4 .2 Soil Samples . . . . . . . . . . . . . . . . . . .3-8

3.4 .3 Conclusions . . . . . . . . . . . . . . . . . . 3-9

3.4.4 Groundwater Assessment . . . . . . . . . . . . . . . 3-10

3.5 116-H-7 PROCESS EFFLUENT RETENTION BASIN . . . . . . . . 3-10

3.5 .1 Geology . . . . . . . . . . . . . . . . . . 3-10

3.5 .2 Soil Sampies . . . . . . . . . . . . . . . . 3-11

3.5 .3 Conclusions . . . . . . . . . . . . . . . 3-11

3.5.4 Groundwater Assessment . . . . . . . . . . . . . . . 3-12

3.6 116-H-9 REACTOR CONFINEMENT SEAL PIT DRAINAGE CRIB . . 3-12

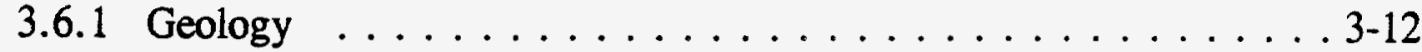

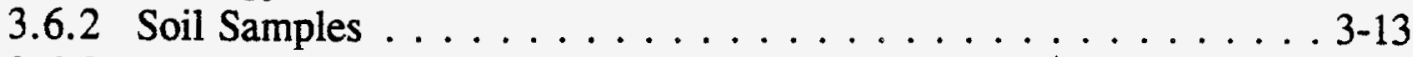

3.6 .3 Conclusions . . . . . . . . . . . . . . . . . 3-13

3.6.4 Groundwater Assessment . . . . . . . . . . . . . . . . 3-14

3.7 NON-INTRUSIVE INVESTIGATION OF OTHER HIGH-PRIORITY

SITES . . . . . . . . . . . . . . . . . . . . . 3-14

3.7.1 116-H-5 Process Effluent Outfall Structure . . . . . . . 3-14

3.7.2 Process Effluent Pipeines . . . . . . . . . . . . . . . 3-15

3.7.3 116-H-7 Sludge Burial Trench . . . . . . . . . . . 3-16

3.7.4 132-H-3 Effluent Pumping Station . . . . . . . . . . . . 3-17

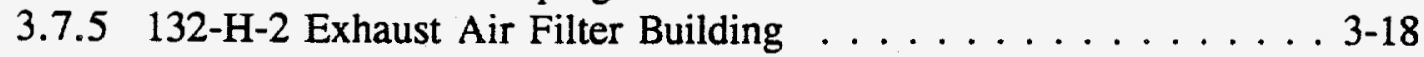

3.7.6 132-H-1 Reactor Exhaust Stack . . . . . . . . . . . . . 3-19

3.7.7 116-H-4 Pluto Crib . . . . . . . . . . . . . . . . . . 3-20

3.8 LOW-PRIORITY SITES INVESTIGATED DURING LFI $\ldots \ldots \ldots 3-21$

3.8.1 1607-H-2 Septic Tank . . . . . . . . . . . . . . . 3-21

3.8 .2 1607-H-4 Septic Tank . . . . . . . . . . . . . . 3-21

3.8.3 Electrical Facilities . . . . . . . . . . . . . . . . 3-22

3.8.4 Support Facilities . . . . . . . . . . . . . . . . 3-23

3.9 APPLICABLE OR RELEVANT AND APPROPRIATE

REQUIREMENTS $\ldots \ldots \ldots \ldots \ldots \ldots \ldots \ldots \ldots \ldots \ldots \ldots \ldots$

4.0 QUALITATIVE RISK ASSESSMENT . . . . . . . . . . . . . . 4-1

4.1 QUALITATIVE RISK ASSESSMENT PROCESS $\ldots \ldots \ldots \ldots \ldots . . .4$

4.1 .1 Approach . . . . . . . . . . . . . . . . . . .4-1

4.1.2 Guidelines Used in the Qualitative Risk Assessment . . . . . . . . . 4-1

4.2 HUMAN HEALTH QUALITATIVE RISK ASSESSMENT . . . . . . 4-2

4.2:1 Overview of the Human Health Risk Evaluation Process . . . . . . 4-3

4.2.2 Results of the Human Health QRA . . . . . . . . . . . 4-4

4.2.3 Summary of Key Uncertainties in the Human Health Risk

Assessment . . . . . . . . . . . . . . . . . . 4-5

4.3 ECOLOGICAL QUALITATIVE RISK ASSESSMENT $\ldots \ldots \ldots \ldots$. . . .7

4.3.1 Results of the Ecological Evaluation . . . . . . . . . 4-8 
DOE/RL-93-51, Rev. 0

\title{
CONTENTS (cont)
}

4.3.2 Summary of Key Uncertainties in the Ecological Evaluation . . . 4-9

5.0 RECOMMENDATIONS . . . . . . . . . . . . . . . . 5-1

5.1 GENERAL CONSIDERATIONS . . . . . . . . . . . . 5-1

5.2 HIGH-PRIORITY SITE IRM CANDIDATE EVALUATION

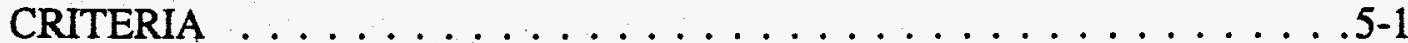

5.2 .1 Conceptual Model . . . . . . . . . . . . . . 5-2

5.2.2 Applicable or Relevant and Appropriate Requirements . . . . . 5-2

5.2 .3 Qualitative Risk Assessment . . . . . . . . . . . . . . 5-2

5.2.4 Current Impact on Groundwater . . . . . . . . . . . . 5-3

5.2.5 Potential for Natural Attenuation . . . . . . . . . . . 5-3

5.3 HIGH-PRIORITY SITE IRM CANDIDATE RECOMMENDATIONS . . . 5-3

5.3.1 116-H-1 Process Effluent Disposal Trench . . . . . . . . . . . . 5-4

5.3.2 116-H-2 Effluent Disposal Trench . . . . . . . . . . . . . 5-4

5.3.3 116-H-3 Dummy Decontamination French Drain . . . . . . . . . 5-5

5.3.4 116-H-7 Process Effluent Retention Basin . . . . . . . . . . . . 5-5

5.3.5 116-H-9 Confinement Seal Pit Drainage Crib . . . . . . . . . . 5-5

5.3.6 116-H-5 Process Effluent Outfall Structure . . . . . . . . . . 5-5

5.3.7 Process Effluent Pipelines - Sludge and Soil $\ldots \ldots \ldots \ldots$. . 5-6

5.3.8 116-H-7 Sludge Burial Trench . . . . . . . . . . . . . 5-6

5.3.9 132-H-3 Effluent Pumping Station, 132-H-2 Exhaust Air Filter

Building, 132-H-1 Reactor Exhaust Stack, and 116-H-4 Pluto

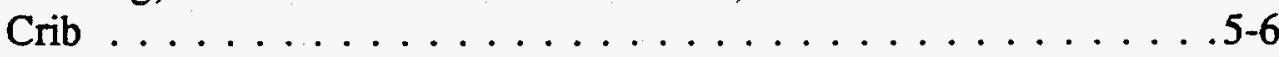

5.4 LOW-PRIORITY SITES RECOMMENDATIONS $\ldots \ldots \ldots \ldots \ldots$. . $\ldots$



\begin{abstract}
APPENDICES:
A - RESULTS OF LABORATORY ANALYSES FOR HIGH-PRIORITY SITES . . . A A-1

B - RESULTS OF LABORATORY ANALYSES FOR LOW-PRIORITY SITES . . . B-1
\end{abstract}

\section{FIGURES:}

1-1 Map of the $100 \mathrm{D} / \mathrm{DR}$ and $100 \mathrm{H}$ Areas Showing the Source and Groundwater

Operable Units . . . . . . . . . . . . . . . . . . . . . . . . . 1F-1

1-2 Hanford Site Past-Practice Strategy Decision Flow Chart . . . . . . . . . 1F-2

2-1 100-HR-1 Sampling Locations .................. . . . . .

3-1 Sampling Results for 116-H-1 Process Effluent Disposal Trench . . . . . . . . . . 3F-1

3-2 Well Locations in the $100 \mathrm{H}$ Area . . . . . . . . . . . . . . . . . . . . . . 3F-2

3-3 Sampling Results for 116-H-2 Effluent Disposal Trench . . . . . . . . . . . . . 3F-3

3-4 Sampling Results for 116-H-3 Dummy Decontamination French Drain . . . . . . . 3F-4

3-5 Sampling Results for 116-H-7 Process Effluent Retention Basin . . . . . . . . . 3F-5 


\section{CONTENTS (cont)}

FIGURES (cont):

3-6 Sampling Results for 116-H-9 Reactor Confinement Seal Pit Drainage Crib . . . . 3F-6

3-7 100-HR-1 Surface Radiological Survey Contamination Points . . . . . . . . . . . 3F-7

5-1 Conceptual Model Contaminant Exposure Pathway for the 100-HR-1 Operable

Unit . . . . . . . . . . . . . . . . . . . . . . .5F-1

\section{TABLES:}

ES-1 100-HR-1 Operable Unit High-Priority Sites and Low-Priority Sites . . . . . EST-1

ES-2 IRM Recommendations for 100-HR-1 High-Priority Sites . . . . . . . . . . . . EST-2

1-1 100-HR-1 Operable Unit Characterization Activities . . . . . . . . . . . . 1T-1

1-2 100-HR-1 Operable Unit High-Priority Sites and Low-Priority Sites . . . . . . . 1T-2

1-3 Summary Statistics and Upper Threshold Limits for Inorganic Analytes . . . . . . 1T-3

2-1 100 Area Analogous Sites . . . . . . . . . . . . . . . . . . . . . . . 2T-1

2-2 LFI Investigation Activities for 100-HR-1 Operable Unit High-Priority Sites . . . 2T-2

2-3 Borehole Expected Waste Depths . . . . . . . . . . . . . . . . . . . 2T-3

2-4 Vadose Zone Boreholes-Sample Collection Information . . . . . . . . . . . 2T-4

2-5 Septic Tanks-Sample Collection Information . . . . . . . . . . . . 2T-5

2-6 Electrical Facilities-PCB Sample Collection Information . . . . . . . . . . . 2T-6

3-1 Summary Statistics and Upper Threshold Limits for Inorganic Analytes . . . . . . 3T-1

3-2 Vadose Zone Borehole 116-H-1-Inorganic Analysis . . . . . . . . . . . . . . . . 3T-2

3-3 Vadose Zone Borehole 116-H-1 -Volatile Organic Analysis . . . . . . . . . . . . . 3T-3

3-4 Vadose Zone Borehole 116-H-1-Semivolatile Organic Analysis . . . . . . . . . . . 3T-4

3-5 Vadose Zone Borehole 116-H-1-Radionuclide Analysis . . . . . . . . . . . 3T-5

3-6 Vadose Zone Borehole 116-H-2-Radionuclide Analysis . . . . . . . . . . . . 3T-6

3-7 Vadose Zone Borehole 116-H-3-Radionuclide Analysis . . . . . . . . . . . . . 3T-7

3-8 Vadose Zone Borehole 116-H-7-Inorganic Analysis . . . . . . . . . . . . . . . . . 3T-8

3-9 Vadose Zone Borehole 116-H-7-Volatile Organic Analysis . . . . . . . . . . . . 3T-9

3-10 Vadose Zone Borehole 116-H-7-Radionuclide Analysis . . . . . . . . . . . . . 3T-10

3-11 Vadose Zone Borehole 116-H-9-Radionuclide Analysis . . . . . . . . . . . . 3T-11

3-12 116-H-5 Process Effluent Outfall Structure-Analogous Data from 116-D-5

Outfall Structure . . . . . . . . . . . . . . . . . . . . . 3T-12

3-13 Septic Tank 1607-H-2-Inorganic Analysis . . . . . . . . . . . . . 3T-13

3-14 Septic Tank 1607-H-2-Volatile Organic Analysis . . . . . . . . . . . . . . . 3T-14

3-15 Septic Tank 1607-H-2-Radionuclide Analysis . . . . . . . . . . . . 3T-15

3-16 Septic Tank 1607-H-4-Inorganic Analysis . . . . . . . . . . . . . . . . 3T-16

3-17 Septic Tank 1607-H-4-Volatile Organic Analysis . . . . . . . . . . . . . 3T-17

3-18 Septic Tank 1607-H-4-Semivolatile Organic Analysis . . . . . . . . . . 3T-18

3-19 Septic Tank 1607-H-4-Pesticide Analysis . . . . . . . . . . . . . . . . . 3T-19

3-20 Septic Tank 1607-H-4-Radionuclide Analysis . . . . . . . . . . . . . . 3T-20

3-21 Electrical Facilities-PCB Analysis . . . . . . . . . . . . . . . . . 3T-21

3-22 Potential Federal Chemical-Specific Applicable or Relevant and Appropriate

Requirements for the 100-HR-1 Operable Unit . . . . . . . . . . . . 3T-22 
DOE/RL-93-51, Rev. 0

\section{CONTENTS (cont)}

\section{TABLES (cont):}

3-23 Potential State Chemical-Specific Applicable or Relevant and Appropriate Requirements for the 100-HR-1 Operable Unit . . . . . . . . . . . . . 3T-23

3-24 Potential Chemical-Specific To-Be-Considered Guidance for the 100-HR-1 Operable Unit . . . . . . . . . . . . . . . . . . . . . . . 3T-24

3-25 Potential Federal Location-Specific Applicable or Relevant and Appropriate Requirements for the 100-HR-1 Operable Unit . . . . . . . . . . . . . . . . 3T-25

3-26 Potential State Location-Specific Applicable or Relevant and Appropriate Requirements for the 100-HR-1 Operable Unit . . . . . . . . . . . . . . 3T-26

3-27 Potential Location-Specific To-Be-Considered Guidance for the 100-HR-1 Operable Unit . . . . . . . . . . . . . . . . . . . . . . . . 3T-27

4-1 Summary of Data Availability and Data Confidence (for sites where data are

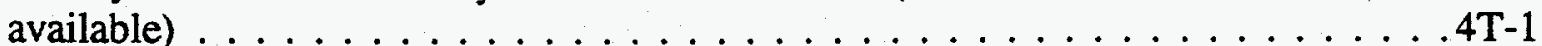

4-2 Human Health Data and Risk Assessment Summary (for sites where only process knowledge is available) ...................... . . . . . . .

4-3 Human Health Risk Assessment Summary (for sites where data are available) . . 4T-3

4-4 Environmental Hazard Quotient Summary for Radionuclides by Waste Site . . . . . 4T-4

4-5 Environmental Hazard Quotient Summary for Non-radiological Contaminants by Waste Site ... . . . . . . . . . . . . . . . . . . . . . . . . .

5-1 100-HR-1 Conceptual Model for High Priority Sites . . . . . . . . . . . . . 5T-1

5-2 Hanford Site Background 95\% Upper Threshold Limits and Model Toxics

Control Act (MTCA) Method B Guidelines for Inorganic Analytes . . . . . . . . . 5T-2

5-3 IRM Recommendations for 100-HR-1 High-Priority Sites . . . . . . . . . . . . 5T-3 


\subsection{INTRODUCTION}

This limited field investigation (LFI) report summarizes the data collection and analysis activities conducted during the 100-HR-1 Source Operable Unit LFI and the Qualitative Risk Assessment of the 100-HR-1 Source Operable Unit (WHC 1993a). An LFI report is required, in terms of the Hanford Past-Practice Strategy (HPPS) (DOE-RL 1991a), when waste sites are to be considered for interim remedial measures (IRM). The LFI is an integral part of the remedial investigation/feasibility study (RI/FS) or Resource Conservation and Recovery Act (RCRA) facility investigation/corrective measures study (RFI/CMS) process and functions as a focused RI or RFI for selection of IRMs. The purpose of the report is to identify those sites that are recommended to remain as candidates for IRMs, to provide a preliminary summary of site characterization studies, to refine the conceptual model as needed, to identify contaminant- and location-specific applicable or relevant and appropriate requirements (ARAR), and to provide a qualitative assessment of the risks . associated with the sites. This assessment also considers whether contaminant concentrations pose an unacceptable risk that warrants action through interim remedial measures. These objectives are described fully in the RCRA Facility Investigation/Corrective Measures Study Work Plan for the 100-HR-1 Operable Unit, Hanford Site, Richland, Washington (DOE-RL 1992a).

The work plan (DOE-RL 1992a) divides the site characterization activities into 12 tasks. These are subjects of the LFI summary of characterization studies. Table 1-1 lists the 12 characterization activities and how each is addressed in the LFI report.

To limit the size of this report and to improve its readability, reliance is placed on the referral to other documents for specific details. This document is unique in that it is based on Hanford-specific agreements discussed in the Hanford Federal Facility Agreement and Consent Order (Tri-Party Agreement)(Ecology et al. 1990), the HPPS, the Hanford Site Baseline Risk Assessment Methodology (HSBRAM), and the RCRA Facility Investigation/Corrective Measures Study Work Plan for the 100-HR-1 Operable Unit (DOE-RL 1992a), and it should be viewed in this context. An IRM, for example, is defined in broad terms and is not restricted to limited or near-term actions. It allows for interim action with a final goal of achieving final action levels. Indeed, an IRM may not be necessary, if it is not likely to lead to a final record of decision (ROD). The qualitative risk assessment (QRA) is used only to assess risk for an IRM determination and is not intended to define current risk or baseline risk in a traditional sense. The final decision to conduct an IRM will rely on many factors, including the QRA, ARARs, future land use, point of compliance, time of compliance, a bias-for-action, and the threat to human health and the environment, including the threat to groundwater.

This LFI report is organized into five major sections, including the introductory section. Chapter 2.0 describes the LFI process, including field investigation, type of sampling, screening, geophysical logging, sample analysis, and data validation activities. Chapter 3.0 presents the results and conclusions of the investigation. Chapter 4.0 summarizes the QRA process, and Chapter 5.0 provides a summary of recommendations. 
The compiled analytical data for the sampling and analysis performed during the LFI process on the high- and low-priority sites are presented in Appendices A and B, respectively.

\subsection{SITE BACKGROUND}

The 100-HR-1 Source Operable Unit is situated within the $100 \mathrm{H}$ Area of the U.S. Department of Energy's (DOE) Hanford Site, in the south-central portion of the state of Washington. The $100 \mathrm{H}$ Area is located in Benton County along the south bank of the Columbia River in the north-central part of the Hanford Site, approximately 27 miles (mi) (43.4 kilometers [km]) north-northwest of Richland, Washington (DOE-RL 1992a).

Covering approximately 100 acres (40.5 hectares), the 100-HR-1 Source Operable Unit is located immediately adjacent to the Columbia River in the northeast portion of the $100 \mathrm{H}$ Area. The operable unit lies primarily within the northeast quadrant of Section 18 of township $14 \mathrm{~N}$, range $27 \mathrm{E}$, and is located between latitude $46^{\circ} 42^{\prime} 30^{\prime \prime}$ and $46^{\circ} 43^{\prime} 30^{\prime \prime}$ north and longitude $119^{\circ} 29^{\prime} 00^{\prime \prime}$ and $119^{\circ} 28^{\prime} 00^{\prime \prime}$ west. Site maps locate it within north/south Hanford Site plant coordinates N94,000 and N99,000 and east/west plant coordinates W37,000 and W41,000 (Figure 1-1) (DOE-RL 1992a).

The 100-HR-1 Source Operable Unit is one of three Operable Units associated with the $100 \mathrm{H}$ Area at the Hanford Site. Two of these units, 100-HR-1 and 100-HR-2, are source operable units composed of waste units. The groundwater/surface-water operable unit is designated 100-HR-3 and includes the entire $100 \mathrm{H}$ Area, the $100 \mathrm{D} / \mathrm{DR}$ Area, and the area in between. The $100 \mathrm{D} / \mathrm{DR}$ Area is located approximately $2 \mathrm{mi}(3.5 \mathrm{~km})$ southwest of the $100 \mathrm{H}$ Area. The 100-HR-1 Source Operable Unit is bordered on the west and south by the 100-HR-2 Source Operable Unit, which is the solid and buried waste operable unit for the $100 \mathrm{H}$ Area. The 100-HR-2 Source Operable Unit consists of solid waste burial grounds that contain radioactive solid wastes, radioactively contaminated equipment, and failed reactor components (DOE-RL 1992a).

Designated as a reactor effluent waste source, the 100-HR-1 Source Operable Unit contains most of the sites involved in Pu production, including the reactor and its cooling system.

The $100 \mathrm{H}$ Reactor complex was constructed after World War II to produce Pu for use in military weapons (WHC 1988a). Fuel elements for the reactor were manufactured in the 300 Area, and the Pu-enriched fuel produced by the reactor was processed in the 200 Area. The H Reactor operated from 1949 to 1965, when it was retired (WHC 1988a). A reactor decommissioning process is ongoing. (Because the reactor is being decommissioned separately, it is not within the scope of this LFI.)

The $100 \mathrm{H}$ Area support facilities included offices, storage buildings for contaminated equipment, warehouses, a laboratory, a garage, maintenance shops, a paint shop and storage, a fallout shelter, a coal-fired electrical generation substation (including coal storage and fly-ash disposal facilities), solid waste burial grounds, a burn pit, a water treatment plant 
(including water intake and storage structures), a river pump house, a process effluent system, and a subsurface sanitary sewage disposal system (WHC 1988a; General Electric 1963). A number of the aboveground facilities have undergone some degree of decommissioning or have been removed completely.

The cooling water treatment system included 16 settling basins, four of which were modified to store and treat liquid process wastes generated at the $\mathrm{N}$ Reactor fuel fabrication facilities. The resulting solar evaporation basins (116-H-6) received these wastes from 1973 through 1985 (WHC 1988a). Therefore, the solar evaporation basins are being handled under RCRA interim status guidelines (WHC 1988a) and will not be addressed further in this report. Currently there are no active facilities, operations, or waste/effluent discharges within the 100-HR-1 Source Operable Unit.

The 100-HR-3 Groundwater Operable Unit is described in the RCRA Facility Investigation/Corrective Measures Study Work Plan for the 100-HR-3 Operable Unit (DOE-RL 1992b). The results of a recently completed LFI for the 100-HR-3 Operable Unit are presented in the Limited Field Investigation Report for the 100-HR-3 Operable Unit, (DOE-RL 1993d). The following groundwater information is from that LFI report.

Groundwater in the $100 \mathrm{H}$ Area generally flows in a northeasterly direction towards the Columbia River. The groundwater table elevation (above mean sea level) at normal to low river stage ranges from 377 feet $(\mathrm{ft})$ (114.9 meters [m]) in the southwest corner to approximately $374 \mathrm{ft}(113.9 \mathrm{~m})$ near the river. The groundwater gradient is approximately 0.0006 . Typical groundwater flow velocities in the uppermost aquifer (Ringold Formation) range from 2 to $6 \mathrm{ft} /$ day $(0.6$ to $2.0 \mathrm{~m} /$ day $)$. The primary non-radioactive constituent contributing to health risk in the $100 \mathrm{H}$ Area groundwater was chloroform (DOE-RL 1993d). The environmental risk assessment for aquatic organisms from non-radioactive contaminants indicated a low to moderate risk when maximum contaminant concentrations from near-river monitoring well samples are used (DOE-RL 1993d).

\subsection{THE HANFORD SITE PAST-PRACTICE STRATEGY AND THE 100-HR-1 LFI}

The signatories to the Tri-Party Agreement (Ecology et al. 1990) recognized the need for a new strategy of RCRA/Comprehensive Environmental Response Compensation and Liability Act (CERCLA) integration to provide greater uniformity in the applicability of requirements to the Hanford Site. Additionally, the signatories agreed that proceeding with the traditional CERCLA approach would likely require too much time and too large a portion of a limited budget to be spent before actual cleanup would occur. Another motivation for a new strategy was the need to coordinate past-practice investigations with RCRA closure activities, since some operable units contain RCRA treatment storage and disposal facilities. This new strategy, the HPPS, is described and justified in The Hanford Federal Facility Agreement and Consent Order Change Packages, dated May 16, 1991 (Ecology et al. 1991). 
In response to the above concerns, the three parties have decided to manage and implement all past-practice investigations under one characterization and remediation strategy (Ecology et al.). In order to enhance the efficiency of ongoing RI/FS and RFI/CMS activities at the 100 Area of the Hanford Site and to expedite the ultimate goal of cleanup, more emphasis will be placed on initiating and completing waste site cleanup through interim actions.

This strategy streamlines the past-practice remedial action process and provides new concepts for the following:

- Accelerating decision-making by maximizing the use of existing data consistent with data quality objectives.

- Undertaking expedited response actions (ERA) and/or IRMs, as appropriate, to either remove threats to human health and welfare and the environment, or to reduce risk by reducing toxicity, mobility, or volume of contaminants.

The HPPS describes the concepts and framework for the RI/FS process in a manner that has a bias-for-action through optimizing the use of interim actions, culminating with decisions on final remedies on both an operable unit and 100 Area aggregate scale. The strategy focuses on reaching early decisions to initiate and complete cleanup projects, maximizing the use of existing data, coupled with focused short-time-frame investigations, where necessary. As more data become available on contamination problems and associated risks, the details of the longer term investigations and studies will be better defined.

Figure 1-2 is a decision flow chart that shows the HPPS process. The strategy includes three paths for interim decision making and a final remedy-selection process for the operable unit that incorporates the three paths and integrates sites not addressed in those paths. An important element of this strategy is the application of the observational approach, in which characterization data are collected concurrently with cleanup.

As shown on Figure 1-2, the three paths for interim decision-making are as follows:

- Expedited response action path, where an existing or near-term unacceptable health or environmental risk from a site is determined or suspected, and a rapid response is necessary to mitigate the problem.

- Interim remedial measures path, where existing data are sufficient to formulate a conceptual model and perform a QRA. If a determination is made that a site continues to be a candidate for an IRM, the process will proceed to select an IRM remedy, and may include a focused FS, if needed, to select a remedy.

- Limited field investigation path, where an LFI can provide sufficient data to formulate a conceptual model and to perform a QRA. The data can be obtained in a less formal manner than that needed to support the operable unit 
ROD; however, regardless of the scope of the LFI, it is a part of the RI process and not a substitute for it.

The near-term past-practice strategy for the 100 Area provides for ERAs, IRMs, and LFIs for individual waste sites, grouped waste sites, and contaminated groundwater. The LFI is an integral part of the RFI/CMS or RI/FS process and functions as a focused RFI or RI for selection of IRMs. The information obtained from the LFIs and interim actions may be sufficient to perform the baseline risk assessment and to select the remedy for the operable unit. If the data are not sufficient, additional investigations and studies will be performed to the extent necessary to support the operable unit remedy selection. These investigations would be performed within the framework and process defined for RI/FS programs. Conversely, the sum of the IRMs may constitute the final cleanup, which would be formalized in a site ROD.

Implementation of the HPPS at the 100-HR-1 Source Operable Unit began with the development of the RCRA Facility Investigation/Corrective Measures Study Work Plan for the 100-HR-1 Operable Unit (DOE-RL 1992a). Through the work plan, the three parties assigned all known and suspected areas of contamination either a high- or low-priority, as listed in Table 1-2. Sites classified as high-priority pose a risk(s) through one or more pathways, any of which are sufficient to warrant a streamlined action via the IRM pathway. Low-priority sites do not pose enough risk to justify streamlining and are deferred to the final remedy selection for this operable unit. The three parties agreed that:

- none of the high-priority sites pose risks that would require an ERA

- limited field sampling was sufficient for those high-priority sites where data are deemed insufficient to formulate the conceptual model and support the QRA

- $\quad$ certain remediation activities would be more efficient to implement at the 100 Area aggregate or Hanford Site scale than the operable unit scale.

The LFI and QRA are part of the 100-HR-1 RFI/CMS, as described by the RCRA Facility Investigation/Corrective Measures Study Work Plan for the 100-HR-1 Operable Unit (DOE-RL 1992a). The work plan includes the following topics that are directly applicable to the 100-HR-1 LFI:

- $\quad$ operable unit site description (Section 2.1)

- $\quad$ operable unit setting (Section 2.2)

- $\quad$ known and suspected contamination (Section 3.1)

- data quality objectives (Section 4.1.1)

- $\quad$ data needs (Section 4.1.2) 
- $\quad$ 100-HR-1 Source Operable Unit sampling and analysis approach (Section 4.2.2)

- $\quad$ limited field investigations (Section 5.1.1)

- 100 Area aggregate studies and Hanford Site studies (Section 5.1.1).

The conceptual model for the 100-HR-1 Operable Unit, presented in Chapter 4 of the work plan (Section 4.1.2) (DOE-RL 1992a), was developed during the RFI scoping process. The conceptual model addresses the following:

- $\quad$ structure and process of the waste sites

- source of contaminants

- type of contaminants

- nature and extent of contamination

- $\quad$ known and potential routes of migration

- known and potential human and environmental receptors.

This conceptual model has been updated with data acquired through the LFI and is presented in Chapter 5.0 of this report.

The 100-HR-1 LFI began the investigative phase of the RI for a select number of high- and low-priority sites. The LFI was performed to provide additional data needed to support the decision concerning selection, design, and implementation of IRMs. The LFI included data compilation, non-intrusive investigations, intrusive investigations, 100 Area aggregate studies, and data evaluation.

\subsection{HISTORICAL DATA}

An integral part of the RFI/CMS process for the 100-HR-1 Operable Unit has been the acquisition, evaluation, and utilization of records pertaining to the construction, operation, and decontamination/decommissioning of the reactor and related $100 \mathrm{H}$ facilities. This information is categorized as historical information and includes operations records and reports, engineering drawings, photographs, interviews with former or retired operations personnel, and data from sampling and analysis of facilities and the local environment.

A primary reference for radiological characterization of the 100-HR-1 Operable Unit sources is a sampling study of the 100 Area performed during 1975-76 by Dorian and Richards (1978). In the 100-HR-1 Source Operable Unit area, Dorian and Richards (1978) collected samples from the retention basins, the effluent pipelines and surrounding soil, a liquid waste disposal trench, a retention basin sludge disposal trench, and the dummy decontamination drain. Samples of soil were collected from the surface and from the subsurface to a maximum of $25 \mathrm{ft}(7.6 \mathrm{~m})$ below grade. Samples were also collected from retention basin sludge and concrete and from effluent line scale and sludge. The samples were analyzed for radionuclides. Inventories of radionuclides for the facilities and sites were 
calculated. Results from Dorian and Richards (1978) were a major resource used in the development of the 100-HR-1 conceptual model and LFI data needs. It should be noted, however, that only concentrations and inventories of selected radionuclides were reported in the 1975-76 study. In particular, Ni-63, which is generally present at activities on the same order of magnitude as Co-60, was reported for only some samples; Tc-99 was not evaluated; and daughter product radionuclides of $\mathrm{Sr}-90$ and $\mathrm{Cs}-137$, which have approximately the same activities as the parent nuclides, were not included in summaries of total activity.

\subsection{AREA AGGREGATE STUDIES}

The 100 Area aggregate studies and Hanford Site studies provide integrated analyses of selected issues on a scale larger than the operable unit, such as the Hanford Site background study. The 100-HR-3 Work Plan (DOE-RL 1992b) addresses activities common to the 100 Area such as a river impact study, a shoreline study, an ecological study, and a cultural resource study. These studies provide data to be used in the LFI. Final remedy selection will be based on the procedures and policies in place at the time of the selection. Results of the Hanford Site background study, the 100 Area ecological study, and cultural resource study that are applicable to the 100-HR-1 LFI are summarized below.

\subsubsection{Hanford Site Background}

Results of the characterization of the natural chemical composition of Hanford Site soils is presented in Hanford Site Background: Part 1, Soil Background for Nonradioactive Analytes (DOE-RL 1993a). The characterization included an analysis of physical properties and factors that might affect the natural soil chemical composition, as determined by regulatory protocols. Hanford Site soils have not been characterized to establish the natural concentrations of the following types of constituents: volatile organic compounds (VOC), semi-volatile organic compounds (SVOC), pesticides and polychlorinated biphenyls (PCB), and radionuclides.

Table 1-3 presents the 95th percentile of the data for a lognormal distribution and the $95 \%$ confidence limit of the 95 th percentile of the data distribution for inorganic analyses of Hanford Site soils (DOE-RL 1993a). The 95\% confidence limit of the 95th percentile of the data distribution, abbreviated as the $95 \%$ upper threshold limit (UTL), was used to define threshold levels. The 95\% UTL values for inorganic constituents have been utilized in the 100-HR-1 QRA (WHC 1993a) to establish site potential contaminants of concern. An inorganic constituent at a site is considered a contaminant if the reported concentration exceeds the $95 \%$ UTL values. Because site-wide background levels for organic and radionuclide constituents have not been established (DOE-RL 1993a), all detected concentrations of these constituents were considered in the QRA as potential contaminants of concern. 


\subsubsection{Ecological Analysis}

Ecological surveys and sampling related to CERCLA have been conducted in the 100 Areas and in and along the Columbia River adjacent to the 100 Areas (Sackschewsky and Landeen 1992; Weiss and Mitchell 1992). Sampling included plants with either a past history of documented contaminant uptake or an important position in the food web, such as river algae, reed canary grass, tree leaves, and asparagus. In addition, samples were collected of caddisfly larvae (next step in the food chain from algae), burrow soil excavated by mammals and ants at waste sites, and pellets cast by raptors and coyote scat to determine possible contamination of the upper end of the food chain. The results of these sample analyses are being compiled and will be presented in separate documents. Other sampling results generated by site-wide surveillance and facility monitoring programs will also be used in the evaluation of ecological contamination.

Bird, mammal, and plant surveys were conducted and reported in Sackschewsky and Landeen (1992). Current contamination data have been compiled from other sources, along with ecological pathways and lists of all wildlife and plants at the site, including threatened and endangered species. This information has been published in Weiss and Mitchell (1992).

Detailed surveys of the $100 \mathrm{H}$ Area are discussed in Appendix D-2, Ecological Investigations, of the 100-HR-3 Groundwater Operable Unit Work Plan (DOE-RL 1992b).

\subsubsection{Cultural Resources Review}

In compliance with Section 106 of the National Historic Preservation Act, and at the request of.Westinghouse Hanford Company (WHC), the Hanford Cultural Resources Laboratory conducted an archaeological survey during fiscal year 1991 of the 100 Area reactor compounds on the Hanford Site. This survey was conducted as part of a comprehensive cultural resources review of the 100 Area operable units in support of CERCLA characterization activities. The work included a literature and records review and pedestrian survey of the project area, following procedures established in the Hanford Cultural Resources Management Plan.

The following paragraphs briefly discuss the topographic, geomorphic, and vegetation characteristics of the 100 Area reactor compounds:

The 100 Area operable units, which cover a total area of 1,834 hectares $\left(18.3 \mathrm{~km}^{2}\right)$ are topographically and environmentally similar. Each is situated along the Columbia River bank, with the reactor located on a high gravel terrace left by the recession of glacial floodwaters at the end of the Pleistocene. Epoch shoreline areas grade from steep banks with narrow cobble beaches to broad, stepped, well-defined floodplain terraces with gently sloping beaches. The floodplain terraces consist of sand deposited during the Holocene epoch and occur on at least two levels, one dating to the early or middle Holocene and another representing the later Holocene. Inland areas are broad flats broken only by stabilized dunes. The area from west of the $100 \mathrm{~N}$ Area to the western edge of the $100 \mathrm{D}$ Area differs 
from this general pattern. The large, rounded gravel mounds in that vicinity are chaotic ripple marks produced by the rush of catastrophic Pleistocene floodwaters.

Vegetation on all sites is dominated by cheatgrass (Bromus tectorum), with scattered big sagebrush (Artemisia tridentata), tumble mustard (Sysimbrium spp.), Russian thistle (Salsola kali), rabbit brush (Chrysothamnus spp.), and needle and thread grass (Stipa comata). Small groves of deciduous trees and shrubs, usually black locust (Robina pseudo-acacia), willow (Salix spp.), and mulberry (Morus spp.) grow along the river bank at the site of early twentieth-century homesteads.

Detailed archeological surveys of the $100 \mathrm{H}$ Area are discussed in Appendix D-3, Cultural Resources Investigations, of the 100-HR-3 Groundwater Operable Unit Work Plan (DOE-RL 1992b). 
Figure 1-1 Map of the $100 \mathrm{D} / \mathrm{DR}$ and $100 \mathrm{H}$ Areas Showing the Source and Groundwater Operable Units

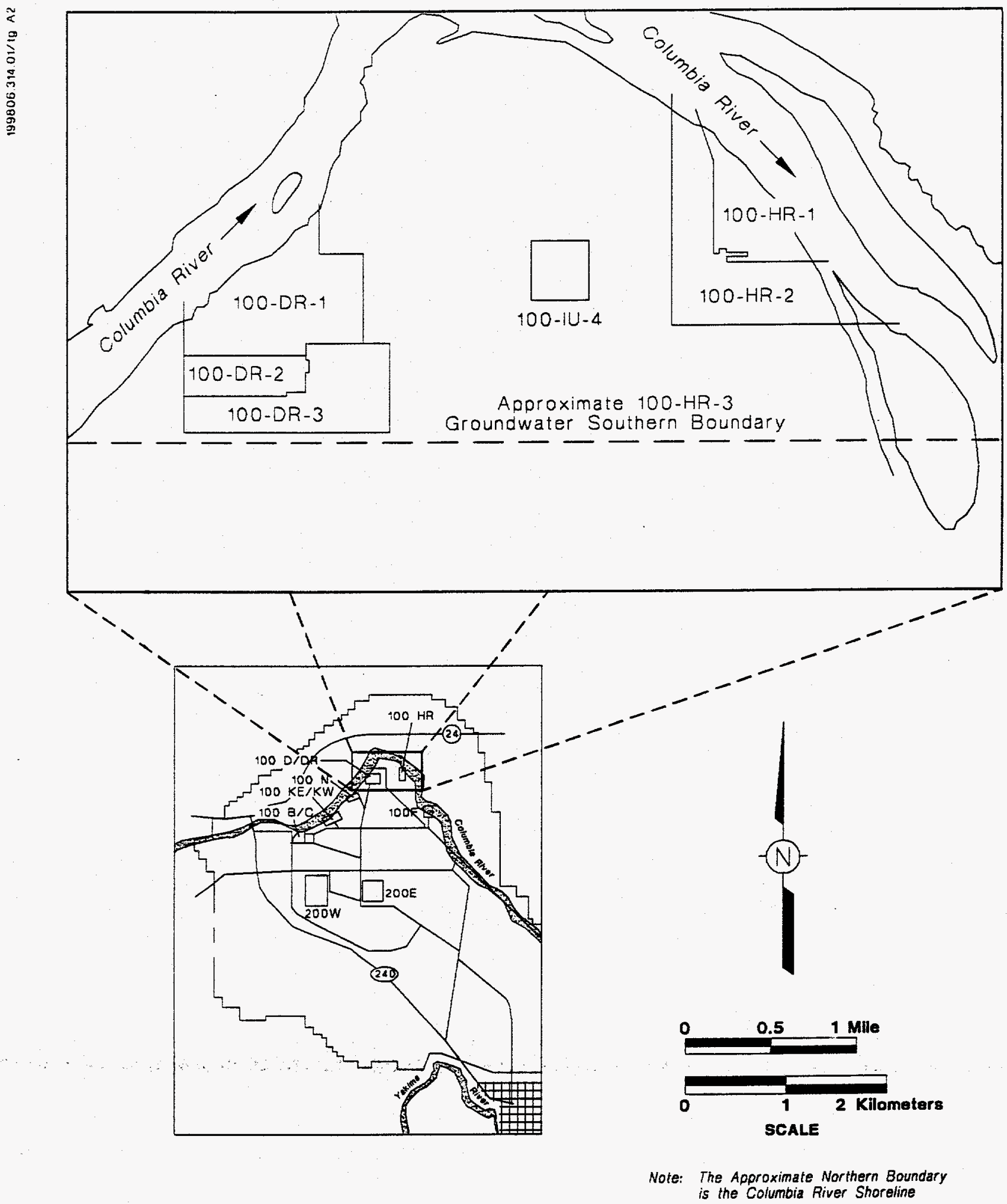




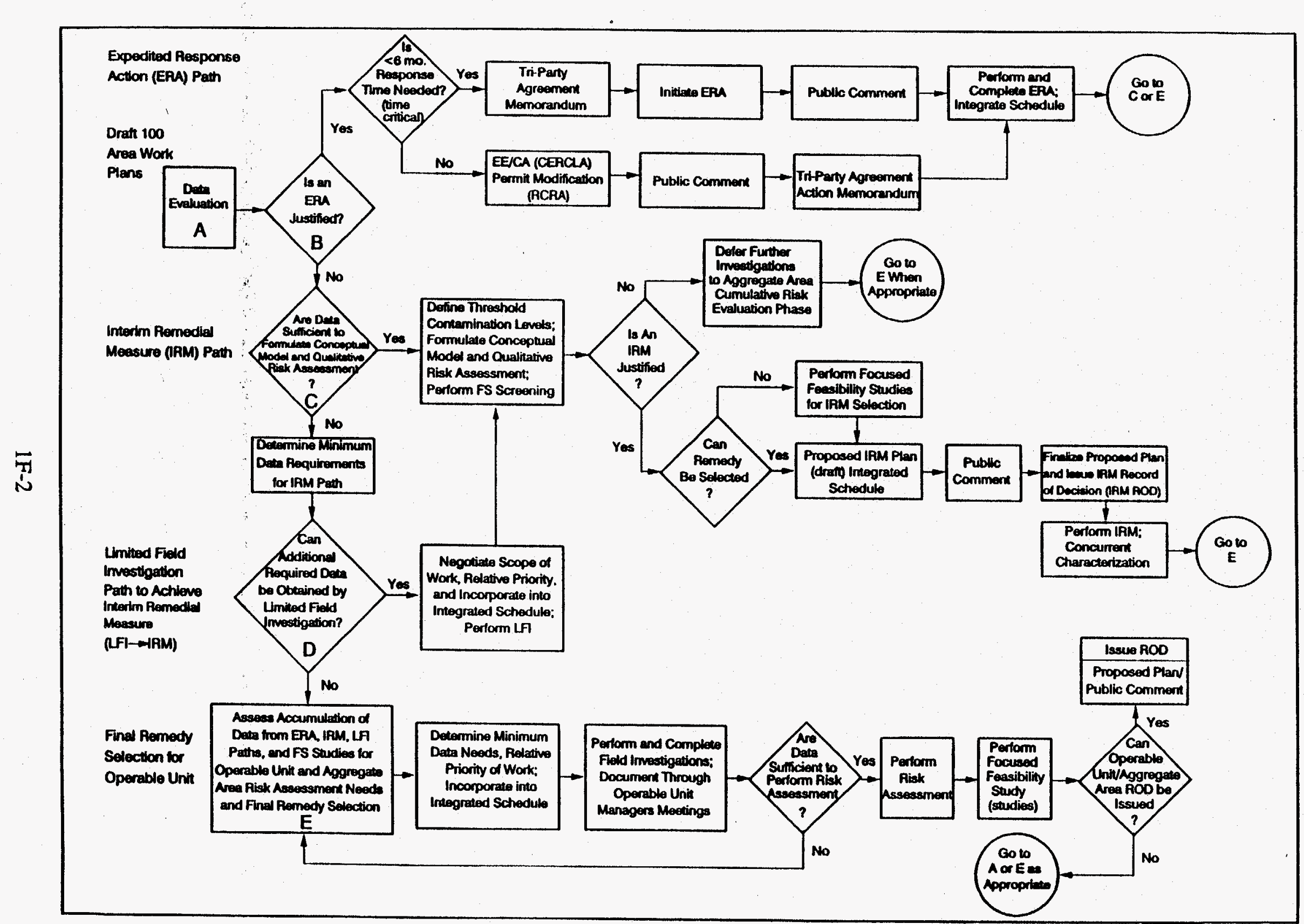


Table 1-1 100-HR-1 Operable Unit Characterization Activities (page 1 of 2)

\begin{tabular}{|c|c|c|}
\hline TASK & TITLE & WHERE ADDRESSED \\
\hline 1 & Project Management & Accomplished throughout project \\
\hline 2 & Source Investigation & See subtasks below \\
\hline $2 a$ & $\begin{array}{l}\text { Source Data Compilation } \\
\text { and Review }\end{array}$ & $\begin{array}{l}\text { Background information is incorporated into the } \\
\text { work plan, QRA and LFI reports as appropriate. }\end{array}$ \\
\hline $2 b$ & Surveying & $\begin{array}{l}\text { Coordinates and locations of sampling sites are } \\
\text { documented in the LFI report (Chapters } 2 \text { and } 3 \text { ). }\end{array}$ \\
\hline $2 c$ & Field Activities & $\begin{array}{l}\text { Field activities including site walkover, surface } \\
\text { radiation survey, and source sampling are in the } \\
\text { LFI report. }\end{array}$ \\
\hline $2 \mathrm{~d}$ & $\begin{array}{l}\text { Source Sample Laboratory } \\
\text { Analysis and Data } \\
\text { Validation }\end{array}$ & $\begin{array}{l}\text { Analytical results and data validation are } \\
\text { documented in data validation reports referenced } \\
\text { in Chapter } 2 \text { of LFI report }\end{array}$ \\
\hline $2 e$ & Source Data Evaluation & $\begin{array}{l}\text { The data was evaluated for use in the QRA and } \\
\text { also evaluated in the LFI report. }\end{array}$ \\
\hline 3 & Geologic Investigation & $\begin{array}{l}\text { Coordinated through the } 100-H R-3 \text { operable unit } \\
\text { tasks. }\end{array}$ \\
\hline 4 & $\begin{array}{l}\text { Surface Water and } \\
\text { Sediments Investigation }\end{array}$ & Not applicable to $100-\mathrm{HR}-1$ \\
\hline 5 & Vadose Zone Investigation & See subtasks below \\
\hline $5 a$ & Data Compilation & See subtask $2 \mathrm{a}$ \\
\hline $5 b$ & $\begin{array}{l}\text { Borehole Soil Sampling and } \\
\text { Logging }\end{array}$ & $\begin{array}{l}\text { Results of the borehole investigations are } \\
\text { presented in the LFI report (Chapter } 3 \text { ). } \\
\text { Borehole logs are displayed in the figures in LFI } \\
\text { report (Chapter 3). }\end{array}$ \\
\hline $5 c$ & Soil Sample Analysis & $\begin{array}{l}\text { The analysis and validation are documented in } \\
\text { the data validation reports referenced in LFI } \\
\text { report (Chapter 2). }\end{array}$ \\
\hline $5 d$ & Geophysical Logging & $\begin{array}{l}\text { The results of the geophysical logging are } \\
\text { reported in the LFI report (Chapter } 3 \text { ). }\end{array}$ \\
\hline $5 e$ & Data Evaluation. & $\begin{array}{l}\text { The data was evaluated for use in the QRA and } \\
\text { also evaluated in the LFI report. }\end{array}$ \\
\hline 6 & Groundwater Investigation & $\begin{array}{l}\text { Performed as part of the } 100-\mathrm{HR}-3 \text { operable unit } \\
\text { activities. }\end{array}$ \\
\hline
\end{tabular}


Table 1-1 100-HR-1 Operable Unit Characterization Activities (page 2 of 2)

\begin{tabular}{|c|c|c|}
\hline TASK & TITLE & WHERE ADDRESSED \\
\hline 7 & Air Investigation & $\begin{array}{l}\text { Routine health and safety monitoring was } \\
\text { performed during the field activities. }\end{array}$ \\
\hline 8 & Ecological Investigation & $\begin{array}{l}\text { A discussion of the ecological investigation is } \\
\text { included in the LFI report (Section 1.4.2). }\end{array}$ \\
\hline 9 & Other Tasks & See subtask below \\
\hline $9 a$ & $\begin{array}{l}\text { Cultural Resource } \\
\text { Investigation }\end{array}$ & $\begin{array}{l}\text { A discussion of the cultural resource investigation } \\
\text { is included in the LFI report (Section 1.4.3). }\end{array}$ \\
\hline 10 & Data Evaluation & $\begin{array}{l}\text { Evaluation and interpretation of the data is } \\
\text { accomplished in the QRA and LFI reports. The } \\
\text { evaluation of the data for other purposes such as } \\
\text { Large Scale Remediation, FS activities and } \\
\text { treatability testing is ongoing. }\end{array}$ \\
\hline 11 & Risk Assessment & $\begin{array}{l}\text { The data generated during the LFI was used in } \\
\text { the QRA and will be used in the baseline risk } \\
\text { assessment in the future. }\end{array}$ \\
\hline 11a & Human Health Evaluation & $\begin{array}{l}\text { In the QRA and summarized in the LFI report } \\
\text { (Chapter 4) }\end{array}$ \\
\hline $11 \mathrm{~b}$ & Ecological Evaluation & $\begin{array}{l}\text { In the QRA and summarized in the LFI report } \\
\text { (Chapter 4) }\end{array}$ \\
\hline 12 & $\begin{array}{l}\text { Verification of Contaminant- } \\
\text { and Location-Specific } \\
\text { ARARs. }\end{array}$ & $\begin{array}{l}\text { ARARs will be addressed in the FS report and } \\
\text { FFS report. } \\
\text { ARARs are also discussed in LFI report (Chapter } \\
\text { 3). }\end{array}$ \\
\hline \multicolumn{3}{|c|}{$\begin{array}{l}\text { ARAR - Applicable or Relevant and Appropriate Requirements } \\
\text { FS - Feasibility Study } \\
\text { FFS - Focused Feasibility Study } \\
\text { LFI - Limited Field Investigation } \\
\text { QRA - Qualitative Risk Assessment }\end{array}$} \\
\hline
\end{tabular}


Table 1-2 100-HR-1 Operable Unit High-Priority Sites and Low-Priority Sites

\begin{tabular}{|c|c|}
\hline HIGH-PRIORITY SITES & LOW-PRIORITY SITES \\
\hline $\begin{array}{l}\text { 116-H-1 Process Effluent Disposal Trench } \\
\text { 116-H-2 Effluent Disposal Trencha } \\
\text { 116-H-3 Dummy Decontamination French Drain } \\
\text { 116-H-7 Process Effluent Retention Basin } \\
\text { 116-H-9 Confinement Seal Pit Drainage Criba } \\
\text { 116-H-5 Process Effluent Outfall Structure } \\
\text { Process Effluent Pipelines (Sludge) } \\
\text { c } \\
\text { Process Effluent Pipelines (Soil) } \\
\text { 116-H-7 Sludge Burial Trench } \\
\text { 132-H-3 Effluent Pumping Station } \\
\text { 132-H-2 Exhaust Air Filter Building } \\
\text { 132-H-1 Reactor Exhaust Stack } \\
\text { 116-H-4 Pluto Crib } \\
\text { 116-H-6 Solar Evaporation Basins } \\
\text { d }\end{array}$ & $\begin{array}{l}\text { 1607-H-2 Septic System } \\
\text { 1607-H-4 Septic System } \\
\text { Electrical Facilities }\end{array}$ \\
\hline $\begin{array}{l}\text { a = Soil sampling conducted as part of the Limite } \\
b=\text { Additional data used from analogous site } \\
c=\text { Remote sensing performed on section of proc } \\
d=116-\mathrm{H}-6 \text { Solar Evaporation Basins are to be } \mathrm{c} \\
\text { and are not further addressed in this document }\end{array}$ & $\begin{array}{l}\text { Id Investigation } \\
\text { fluent pipeline } \\
\text { ered under RCRA Interim Status }\end{array}$ \\
\hline
\end{tabular}

Source: DOE-RL 1992a 
DOE/RL-93-51, Rev. 0

Table 1-3 Summary Statistics and Upper Threshold Limits (UTL) for Inorganic Analytes*

\begin{tabular}{|c|c|c|}
\hline Analyte & $\begin{array}{l}\text { 95\% Distribution } \\
(\mathrm{mg} / \mathrm{kg})\end{array}$ & $\begin{array}{c}95 \% \mathrm{UTL}^{\mathrm{b}} \\
(\mathrm{mg} / \mathrm{kg})\end{array}$ \\
\hline $\begin{array}{l}\text { Aluminum } \\
\text { Antimony } \\
\text { Arsenic } \\
\text { Barium } \\
\text { Beryllium } \\
\end{array}$ & $\begin{array}{c}13,800 \\
\text { NR } \\
7.59 \\
153 \\
1.62 \\
\end{array}$ & $\begin{array}{c}15,600 \\
15.7^{\circ} \\
8.92 \\
171 \\
1.77\end{array}$ \\
\hline $\begin{array}{l}\text { Cadmium } \\
\text { Calcium } \\
\text { Chromium } \\
\text { Cobalt } \\
\text { Copper } \\
\end{array}$ & $\begin{array}{c}\text { NR } \\
20,410 \\
23.4 \\
17.9 \\
25.3 \\
\end{array}$ & $\begin{array}{c}0.66^{c} \\
23,920 \\
27.9 \\
19.6 \\
28.2 \\
\end{array}$ \\
\hline $\begin{array}{l}\text { Iron } \\
\text { Lead } \\
\text { Magnesium } \\
\text { Manganese } \\
\text { Mercury }\end{array}$ & $\begin{array}{c}36,000 \\
12.46 \\
7,970 \\
562 \\
0.614\end{array}$ & $\begin{array}{c}39,160 \\
14.75 \\
8,760 \\
612 \\
1.25\end{array}$ \\
\hline $\begin{array}{l}\text { Nickel } \\
\text { Potassium } \\
\text { Selenium } \\
\text { Silver } \\
\text { Sodium } \\
\end{array}$ & $\begin{array}{c}22.4 \\
2,660 \\
\text { NR } \\
1.4 \\
963 \\
\end{array}$ & $\begin{array}{c}25.3 \\
3,120 \\
5^{c} \\
2.7 \\
1,290 \\
\end{array}$ \\
\hline $\begin{array}{l}\text { Thallium } \\
\text { Vanadium } \\
\text { Zinc } \\
\text { Molybdenum } \\
\text { Titanium } \\
\end{array}$ & $\begin{array}{c}\text { NR } \\
98.2 \\
73.3 \\
\text { NR } \\
3,020\end{array}$ & $\begin{array}{c}3.7^{c} \\
111 \\
79 \\
1.4^{c} \\
3,570\end{array}$ \\
\hline $\begin{array}{l}\text { Zirconium } \\
\text { Lithium } \\
\text { Ammonia } \\
\text { Alkalinity } \\
\text { Silicon } \\
\end{array}$ & $\begin{array}{c}47.3 \\
35 \\
15.3 \\
13,400 \\
108\end{array}$ & $\begin{array}{c}57.3 \\
37.1 \\
28.2 \\
23,300 \\
192 \\
\end{array}$ \\
\hline $\begin{array}{l}\text { Fluoride } \\
\text { Chloride } \\
\text { Nitrite } \\
\text { Nitrate } \\
\text { Ortho-phosphate } \\
\text { Sulfate }\end{array}$ & $\begin{array}{c}6.4 \\
303 \\
\text { NR } \\
96.4 \\
3.7 \\
580\end{array}$ & $\begin{array}{c}12 \\
763 \\
21^{\circ} \\
199 \\
16 \\
1,320\end{array}$ \\
\hline
\end{tabular}

*Source: DOE-RL 1993a.

NR $=$ Not reported.

95th percentile of the data for a lognormal distribution.

b5 percent confidence limit of the 95th percentile of the data distribution.

'Limit of detection. 


\subsection{INVESTIGATIVE APPROACH}

The 100-HR-1 LFI process consisted of intrusive investigations, sampling and subsequent analysis, evaluation of data collected from analogous sites by LFIs at other 100 Area operable units, evaluation of historical data, and a QRA. The 100-HR-1 Source Operable Unit LFI included all the high-priority sites identified in the work plan (DOE-RL 1992a) and several low-priority sites. Intrusive sampling activities, in the form of drilling vadose zone boreholes, took place at the following high-priority sites:

- 116-H-1 process effluent disposal trench

- $\quad 116-\mathrm{H}-2$ effluent disposal trench

- 116-H-3 dummy decontamination French drain

- 116-H-7 process effluent retention basin

- 116-H-9 reactor confinement seal pit drainage crib.

Data from an intrusive LFI investigation of analogous sites in the 100-DR-1 Source Operable Unit were applied to the LFI evaluation of the 116- $\mathrm{H}-5$ outfall structure and to the 132-H-3 effluent pumping station. Each of the reactors and their support facilities in the $100 \mathrm{~B} / \mathrm{C}, 100 \mathrm{H}$, and $100 \mathrm{D} / \mathrm{DR}$ Areas are similar in construction and use. An analogous site is a site associated with one of the other 100 Area reactors which has a similar process history, waste stream, and expected suite of contaminants to a site in the 100-HR-1. An analogous site does not necessarily have the same geology or contaminant concentrations. Table 2-1 presents 100 Area analogous sites.

Non-intrusive investigations of the other 100-HR-1 high-priority sites (116- $\mathrm{H}-7$ sludge burial trench, 132-H-2 exhaust air filter building, 132- $\mathrm{H}-1$ reactor exhaust stack, 116-H-4 . pluto crib) relied on historical data such as that from past sampling and analysis (Dorian and Richards 1978) and process knowledge. Table 2-2 lists the LFI investigative approaches applied to the high-priority sites.

Sampling activities also took place at the following low-priority sites:

- 1607-H-2 septic tank

- $1607-\mathrm{H}-4$ septic tank

- two inactive electrical facility sites.

An investigation of a section of the process effluent pipeline using remote sensing equipment was also performed. Additionally, ground-penetrating radar (GPR) and radiological surveys were performed during a surface-area walkover of the 100-HR-1 Source Operable Unit. This chapter discusses the investigation techniques used at the high- and low-priority sites within the 100-HR-1 Source Operable Unit. 


\subsection{FIELD INVESTIGATION}

Intrusive investigations of the 100-HR-1 Source Operable Unit LFI were performed using vadose borehole drilling through selected high-priority waste disposal sites. A test pit was constructed at the low-priority $1607-\mathrm{H}-4$ septic tank, and liquid and sludge sampling was performed at the low-priority $1607-\mathrm{H}-2$ septic tank. Surface soil sampling was performed at selected low-priority 100 Area electrical facilities where visible surface soil contamination by PCBs was suspected.

The investigative methods are proven methods that allow appropriate sample extraction. Once the desired samples are taken, they are shipped off site for laboratory analysis and the results are then the analyses returned for validation and evaluation. (All samples shipped to off-site laboratories received a preshipping radiological characterization for total activity at the 222-S Laboratory on the Hanford Site.) The following sections describe the LFI process in detail.

\subsubsection{Vadose Zone Boreholes}

Five boreholes were advanced using cable tool drilling methods and sampled using split-spoon samplers (see Figure 2-1 for sampling locations). Cable tool equipment was used for this task due to the presence of gravel, cobbles, and boulders. Detailed procedures for drilling and sampling are described in the Environmental Investigations and Site Characterization Manual, Section 6 - Drilling.

The depth of each borehole was based on expected waste depth and field screening results for radionuclides and VOCs. Use of the field screening instruments is discussed in Section 2.4 .

\subsubsection{Low-Priority Sites}

2.1.2.1 1607-H-2 Septic Tank. Five liquid samples and two sludge samples were taken from the 1607-H-2 septic tank for chemical and radionuclide analysis (see Figure 2-1 for tank location).

2.1.2.2 1607-H-4 Septic Tank. The liquid and sludge wastes at the 1607-H-4 septic tank could not be sampled directly, because the septic tank had been backfilled with a mixture of soil and large rocks. The size of both the fill material and the tank prevented installation of a borehole in the septic tank. As an alternative sampling method, a test pit was constructed in the tile/leach field consisting of two trenches in an " $\mathrm{L}$ " shape in the leach field immediately downstream from the septic tank. The first trench was excavated across the two drain legs of the leach field. The second trench was excavated along one of the two drain legs so that samples could be obtained from around the tiles. The trenches were excavated to a depth of approximately $4 \mathrm{ft}(1.2 \mathrm{~m})$ (see Figure $2-1$ for tank location). Four soil samples were taken for chemical and radionuclide analysis during the test pit excavation. 
2.1.2.3 Electrical Facilities. Surface-soil sampling was conducted at two inactive electrical facility sites within the 100-HR-1 Source Operable Unit, in an effort to determine if PCB contamination of the soil had occurred (see Figure 2-1 for electrical facility sampling locations). A total of eight surface soil samples were analyzed for PCB contamination during the investigation.

2.1.2.4 Surface-Area Walkover. Surface-area walkover surveys were conducted within the 100-HR-1 Source Operable Unit. These walkovers included a GPR survey of specific areas to help locate some of the high-priority sites and a radiological survey of the entire operable unit to identify areas of high radioactive surface contamination.

\subsection{PHYSICAL PROPERTIES SAMPLING}

Three physical properties samples were taken in support of "EPA Physical Sampling Criteria for the 100 Areas," Attachment 1 of the 100-HR-1 Operable Unit Work Plan (DOE-RL 1992a). The physical property samples were analyzed for the following parameters using American Society for Testing and Materials (ASTM) methods. Bulk density and $\mathrm{K}_{\text {unese }}$ were calculated.

- $\quad$ bulk density

- $\quad$ particle size distribution (ASTM D422-63)

- $\quad$ moisture content (ASTM D2216)

- moisture retention (ASTM D2325-68, D3152-72)

- $\quad$ saturated hydraulic conductivity ( $\mathrm{K}_{\mathrm{sad}}$ (ASTM D2434-68)

- unsaturated hydraulic conductivity $\left(\mathrm{K}_{\text {unsat }}\right)$ at $10 \%$ moisture content after full saturation.

\subsection{GEOPHYSICAL DATA}

\subsubsection{Vadose Zone Boreholes}

2.3.1.1 Borehole Logging. Logging with a high-resolution, high-purity germanium, passive, spectral gamma-ray system was performed on four vadose boreholes within the 100-HR-1 Source Operable Unit per Environmental Investigation Instruction (EII) 11.1, Geophysical Logging (WHC 1991a). The objective of the borehole surveys was to identify the presence of man-made gamma-emitting radionuclides and to support the analytical results from soil sampling of the boreholes. The complete results of the borehole logging can be found in Spectral Gamma-Ray Log Report for the 100 Area Borehole Surveys (WHC 1993b). 
2.3.1.2 Ground-Penetrating Radar. Ground-penetrating radar surveys were conducted at several of the high-priority sites within the 100-HR-1 Source Operable Unit. The purpose of the GPR surveys was to assist in determining the location and lateral extent of the waste sites. The surveys were conducted in accordance with EII 11.2, Geophysical Survey Work, Rev. 1 (WHC 1991a). The complete results of the GPR surveys are presented in 100-HR-1 Geophysical Surveys (Mitchell and Kunk 1991).

\subsubsection{Low-Priority Sites}

Surface Radiological Survey. A radiological survey was conducted over the entire surface of the 100-HR-1 Source Operable Unit to measure gross gamma radiation levels of the surface soil (Beckstrom and Wade 1991). The purpose of the survey was to identify areas of radioactive surface contamination. The survey was conducted in accordance with the following procedures contained within the Health Physics Procedures Manual (WHC 1991b):

- Section 1.05, Ultrasonic Ranging and Data System: Connecting the Equipment, Rev. 0

- Section 1.06, Ultrasonic Ranging and Data System: Equipment Setup, Rev. 0

- Section 1.07, Ultrasonic Ranging and Data System: System Calibration, Rev. 0

- Section 1.08, Ultrasonic Ranging and Data System: Performing the Survey, Rev. 0.

Initially, a background level survey was performed off site to characterize background conditions. The entire operable unit surface was then surveyed. The operable unit was broken up into 200 by $200 \mathrm{ft}(61$ by $61 \mathrm{~m})$ grid blocks. Each grid block was traversed on approximately $25 \mathrm{ft}(7.6 \mathrm{~m})$ transects (generally in the north-south direction). Closer transect spacing was implemented when significantly higher than background readings were encountered.

\subsection{SOIL SCREENING}

\subsubsection{Vadose Zone Boreholes}

All soil samples and cuttings from the five vadose boreholes were field screened for evidence of VOCs and radionuclides. If any of the field screening action levels were exceeded, soil sampling was to be initiated as specified in the applicable description of work (and summarized in Section 2.5.1 below). Volatile organic compounds were screened using an organic vapor monitor (OVM) that was used, maintained, and calibrated consistent with 
EII 3.2, Health and Safety Monitoring Instruments, and EII 3.4, Field Screening (WHC 1991a). Radionuclides were screened by the field geologist using a Geiger-Mueller instrument, and all sample screening data were recorded on the borehole logs per EII 9.1, Geologic Logging (WHC 1991a).

The action level for radionuclide screening was set at twice the background level. The action level for VOCs was set at 10 parts per million (ppm) above background. The background levels were determined at the start of each shift at a chosen background site located near the Columbia River, generally north of the sampling location.

Total $\mathrm{Cr}$ screening was performed on samples from the bottom of each vadose borehole using a portable $\mathrm{Cr}$ test kit. Because the test method is currently under development, the screening was performed for informational purposes only; therefore, an action level was not set and the results were not used to make decisions in the field nor are they reported in this report.

The capabilities and the limitations of these field screening methods should be noted. The VOC field screening method provides an estimate of the vapor concentration resulting from subsurface contamination of VOCs. The detected concentration should be interpreted only in a semi-quantitative manner with more emphasis on relative values than on absolute values. Similarly, the Geiger-Mueller instrument generally detects gamma radiation only and will not detect alpha or low energy beta emissions. Again, the detected counts per minute should be interpreted as relative values rather than absolute values. As stated previously, the $\mathrm{Cr}$ screening kit is under development and results should be used for informational purposes only.

\subsubsection{Low-Priority Sites}

2.4.2.1 1607-H-2 and 1607-H-4 Septic Tanks. Liquid, sludge, and soil samples were field screened for VOCs and radionuclides. Volatile organic compounds were screened using an OVM, per EII 3.2, Health and Safety Monitoring Instruments (WHC 1991a). Radionuclide screening was performed using a Geiger-Mueller instrument with a P-11 probe. The action level for radionuclide screening was set at twice the background level. The action level for VOCs was set at $5 \mathrm{ppm}$ above background. The background level was determined by the field team leader at a point $3 \mathrm{ft}(1 \mathrm{~m})$ above the sampling site before any disturbance of the area (e.g., opening the tank or excavation).

2.4.2.2 Electrical Facilities. Surface-soil samples taken at potential PCB contamination sites were screened for radioactivity. 


\subsection{SOIL SAMPLING}

\subsubsection{Vadose Zone Boreholes}

Soil sampling intervals in the vadose boreholes were selected on the basis of field screening results and the predicted waste site target depths. Soil removed from the vadose borehole was screened continuously for VOCs and radioactivity. The borehole was deepened until either sediment was encountered that exceeded the field screening action level, or the maximum expected waste site target depth was reached. Once action levels were exceeded, sampling then continued at $5 \mathrm{ft}(1.5 \mathrm{~m})$ intervals until either two consecutive sample intervals did not exceed the action level, or the borehole had reached a depth $5 \mathrm{ft}(1.5 \mathrm{~m})$ below the water table. If sediment did not exceed the action levels and the maximum expected waste site target depth had been reached, sampling continued at $5 \mathrm{ft}(1.5 \mathrm{~m})$ intervals until two consecutive samples did not exceed the action levels.

Analytical samples were collected using 5 inch (12.7 centimeter [cm]) outside-diameter split-spoon samplers, per EII 5.2, Soil and Sediment Sampling (WHC 1991a). Geologic soil samples that passed the screening criteria in Section 2.4.1 were collected at 5-foot $(1.5 \mathrm{~m})$ intervals and were archived, per EII 5.7A, Hanford Geotechnical Sample Library Control (WHC 1991a).

The boreholes and their associated expected waste depths and estimated depth to groundwater, based upon process knowledge and historical data, are shown in Table 2-3.

\subsubsection{Low-Priority Sites}

2.5.2.1 1607-H-2 Septic Tank. Five water and two sludge samples were collected from the intact 1607-H-2 septic tank. The septic tank has three man-holes aligned north to south. The five water samples were taken from the northern most man-hole using a dip pole with a 1 liter (L) bottle on the end. The sludge samples were taken from the sludge at the bottom of the septic tank at the middle and southern most man-holes (samples B00ZM7 and B00ZM6, respectively). Sampling was performed using a large ladle on the end of an aluminum pole.

2.5.2.2 1607-H-4 Septic Tank. Four analytical samples were collected directly from the backhoe bucket using hand tools and standard soil sampling techniques, per EII 5.2, Soil and Sediment Sampling (WHC 1991a). The bucket of the backhoe was cleaned of visible dirt before sampling and between sample locations. A bucket of soil was removed from the desired sampling interval and brought to the side of the test pit. Samples were collected from soil in the middle of the bucket, away from the bucket sides.

2.5.2.3 Electrical Facilities. Surface-soil samples were collected in accordance with EI 5.2, Soil and Sediment Sampling (WHC 1991a). Eight samples were taken from two locations in the 100-HR-1 Source Operable Unit. Sampling sites were selected based on 
signs of spills identified during visual inspections or at uncleared abandoned electrical facility sites.

\subsection{SAMPLE ANALYSIS}

All samples collected for chemical analysis were analyzed for the full suite of radionuclides and CERCLA Contract Laboratory Program (CLP) target compound list (TCL) and target analyte list (TAL) constituents. The CLP TCL constituents are VOCs, SVOCs, pesticides, and PCBs. The CLP TAL constituents include metals and cyanide. Chemical analysis was conducted using CLP methods. Appendices A and B present a summary of the analytical data set. Table 2-4 presents the location, depth, and assigned laboratory for each sample taken as part of the vadose zone borehole investigation. Figure 2-1 shows relative borehole locations. Tables $2-5$ and $2-6$ present the location and assigned laboratory for the samples taken at the low-priority sites.

Samples from electrical facilities were analyzed for PCBs following CLP protocols using U.S. Environmental Protection Agency (EPA) SW-846 Method 8080 (EPA 1986).

Analytical methods, routine analytical detection and quantitation limits, and precision and accuracy specified for the methods are listed in Table QAPjP-1 of the Quality Assurance Project Plan in the 100-HR-1 Operable Unit Work Plan (DOE-RL 1992a).

\subsection{DATA VALIDATION}

Data validation was performed by a qualified independent participant contractor. The validation responsibilities are defined in associated statements of work. All data validation was performed in compliance with WHC Sample Management and Administration Manual (WHC 1990), Section 2.2 for organics analyses, Section 2.1 for inorganics analyses, and Sections 2.3 and 2.4 for radionuclide analyses. All data packages were assessed. Most of the chemical and radionuclide data were validated (data from sample number B05WV5 were not validated). The physical property data were not validated. The following reports present the data validation process:

- Data Validation Report for the 100-HR-1 Operable Unit Vadose Boreholes, (WHC 1992a)

- Data Validation Report for the 100-HR-1 Operable Unit H-2 Septic Samples, (WHC 1992b)

- Data Validation Report for the 100-HR-1 Operable Unit H-4 Septic Samples, (WHC 1992c)

- Data Validation Report for the 100-HR-1 Operable Unit Electrical Facilities, (WHC 1992d). 
In addition to the data validation identified above, the LFI data were evaluated for use in the LFI and QRA. The first step in the data evaluation process was to develop a detailed inventory of all samples collected for the LFI. This information was gathered from the project sample list, borehole logs, sample tracking sheets, and sample location maps. Multiple information sources were reviewed, as no one source contained all required information.

The second step was to compile and review the analytical data. This was done to verify that validation results are incorporated into the analytical database and that data qualifiers are listed. Rejected data were assigned the qualifier "R." Data rejected for major quality deficiencies (e.g. technical concerns) were not used; however, data rejected for administrative reasons (missing documentation) were used. Data sources were Hanford Environmental Information System (HEIS), CLP analysis data disks, validated analytical reports, i.e., "form 1 " sheets, and CLP data packages.

The third step was to review trip, equipment, and field blank data to determine if sample data detections were due to sources other than media contamination. This review was conducted using the EPA's "five or ten times rule." The ten times rule applies to common laboratory contaminants, e.g., methylene chloride, acetone, toluene, 2-butanone, and common phthalate esters. Detected concentrations of common lab contaminants had to be greater than 10 times their corresponding blank value to be considered valid. Detected concentrations of other contaminants had to be greater than five times their corresponding blank value to be considered valid (EPA 1986).

One result of the data evaluation and validation process is the assignment of data qualifier letter codes to individual analytical results. The following qualifier letter codes were applied to data from the LFI investigation:

- $\quad$ "U" indicates that the analyte was analyzed for and not detected. The numerical value reported is the contract required detection limit (CRDL) or the contract required quantitation limit (CRQL). Contract required detection limits apply to EPA CLP protocol analyses of inorganic constituents and to detection limits established by WHC for radionuclide analyses. Contract required quantitation limits apply to EPA CLP protocol analyses of organic constituents. Sample quantitation limits and sample detection limits may be lower or higher than CRQLs or CRDLs, depending on instrumentation, matrix, and concentration factors.

- $\quad \mathrm{J}$ " indicates that the analyte was analyzed for and detected. The concentration reported is an estimate due to identified quality control deficiencies. For example, if the amount present is less than either the CRDL or CRQL, the concentration reported is considered an estimated value.

- "UJ" indicates the analyte was analyzed for and not detected and the detection or quantitation limit for the sample can only be estimated due to identified quality control deficiencies. 
- $\quad \mathrm{JN}$ " indicates the analyte was analyzed for and that there is presumptive evidence for the presence of the analyte. The concentration reported is considered an estimate usable only for information purposes.

- $\quad \mathrm{E}$ " indicates the analyte was analyzed for and detected at a concentration outside the calibration range of the instrument. The reported concentration is an estimate possibly containing significant error.

- $\quad \mathrm{R}$ " indicates that the data were rejected during validation because of quality assurance problems.

- $\quad$ "B" indicates that the analyte was detected in the sample and in the blank associated with the sample.

Data marked with " $\mathrm{J}$ " or " $\mathrm{R}$ " qualifiers were used for the LFI and QRA as indications of contamination present, as were data that had no qualifiers attached. Data that were marked with " $U$ " or "UJ" qualifiers were not used indicating no contamination present above detection limits. Data that were marked with "B" qualifiers were evaluated using the EPA five and ten times rule to assess if they were usable. 
Figure 2-1 100-HR-1 Sampling Locations

$\bar{c}$
9
5
5
0
5
0
0
0
0
0

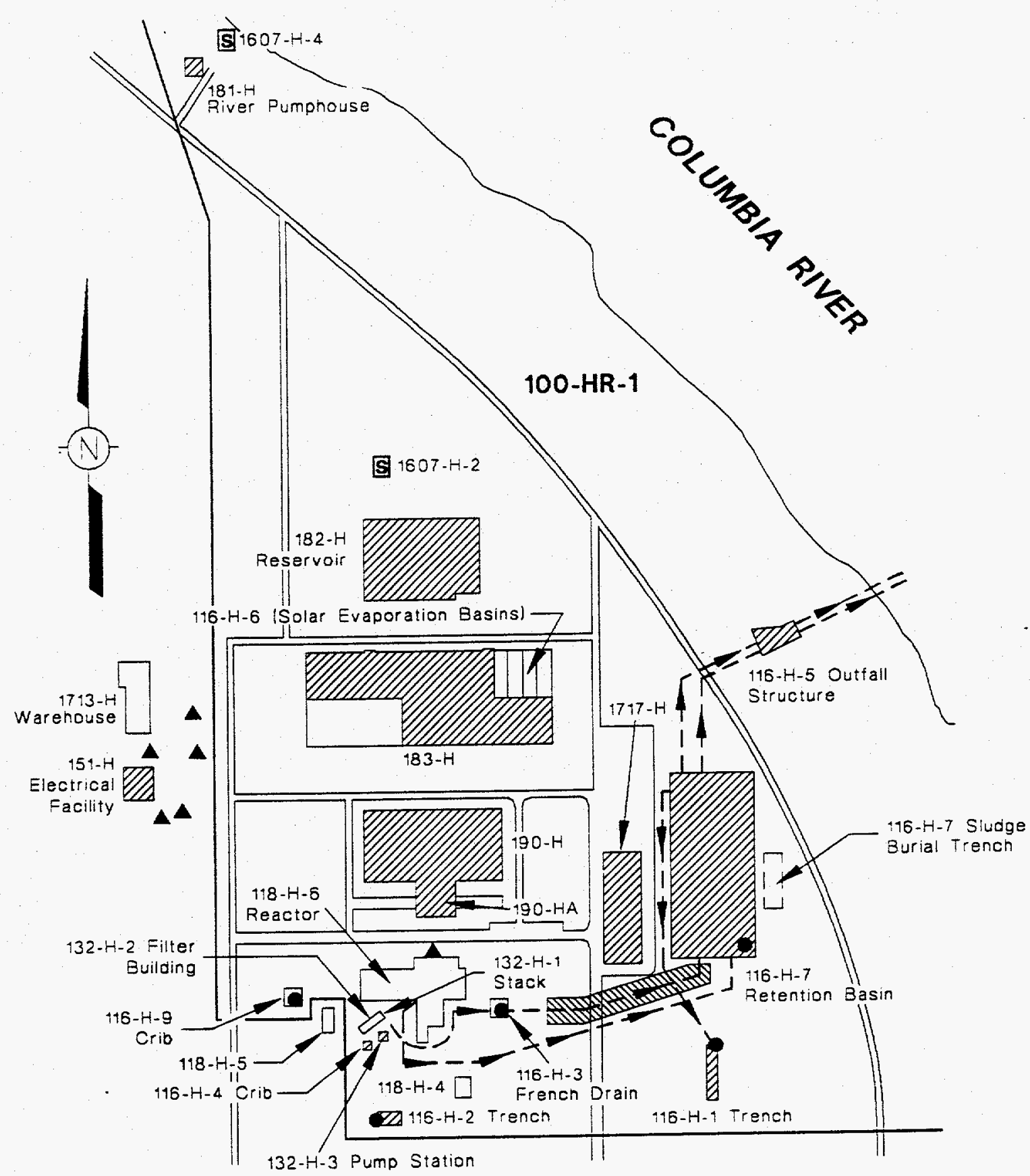

\section{LEGEND}

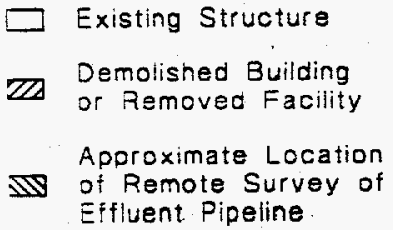

Locations of Boreholes

- Electrical Facilities

Sample Location

- Effluent Pipeline

S Septic Tank/Leachfield

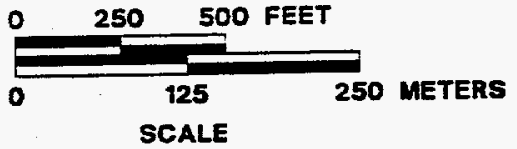

Note: Facility locations and sizes are approximations 
DOE/RL-95-51, Rev. 0

Table 2-1 100 Area Analogous Sites

\begin{tabular}{|c|c|c|c|}
\hline Waste Site Description & $\begin{array}{l}\text { 100-B/C Area } \\
\text { Site }\end{array}$ & $\begin{array}{l}\text { 100-D/DR Area } \\
\text { Site }\end{array}$ & $\begin{array}{l}\text { 100-H Area } \\
\text { Site }\end{array}$ \\
\hline Process Effluent Disposal Trench & $116-\mathrm{B}-1$ & $\begin{array}{l}\text { 116-DR-1 } \\
\text { 116-DR-2 }\end{array}$ & $116-\mathrm{H}-1$ \\
\hline Fuel Storage Basin Trench & $116-\mathrm{B}-2$ & $\begin{array}{l}116-D-1 a \\
116-D-1 b\end{array}$ & --- \\
\hline $\begin{array}{l}\text { Dummy Decontamination French } \\
\text { Drain }\end{array}$ & 116-B-4 & - & $116-\mathrm{H}-3$ \\
\hline Process Effluent Retention Basin & $\begin{array}{l}116-\mathrm{B}-11 \\
116-\mathrm{C}-5\end{array}$ & $\begin{array}{l}\text { 116-D-7 } \\
116-\mathrm{DR}-9\end{array}$ & $116-\mathrm{H}-7$ \\
\hline $\begin{array}{l}\text { Reactor Confinement Seal Pit } \\
\text { Drainage Crib }\end{array}$ & $-\ldots$ & 116-D-9 & $116-\mathrm{H}-9$ \\
\hline $\begin{array}{l}\text { Process Effluent Outfall } \\
\text { Structure }\end{array}$ & $\begin{array}{l}116-B-7 \\
132-B-6 \\
132-C-2\end{array}$ & $\begin{array}{c}116-\mathrm{D}-5 \\
116-\mathrm{DR}-5\end{array}$ & $116-\mathrm{H}-5$ \\
\hline Process Effluent Pipelines & $\begin{array}{c}\text { Process Effluent } \\
\text { Pipelines }\end{array}$ & $\begin{array}{l}\text { Process Effluent } \\
\text { Pipelines }\end{array}$ & $\begin{array}{l}\text { Process Effluent } \\
\text { Pipelines }\end{array}$ \\
\hline Effluent Pumping Station & -- & 132-D-3 & $132-\mathrm{H}-3$ \\
\hline Exhaust Air Filter Building & 132-B-4 & $117-\mathrm{D}$ & $132-\mathrm{H}-2$ \\
\hline Pluto Crib & $\begin{array}{l}116-\mathrm{B}-3 \\
116-\mathrm{C}-2\end{array}$ & $116-\mathrm{D}-2 \mathrm{a}$ & $116-\mathrm{H}-4$ \\
\hline Gas Recirculation Building & 132-B-5 & $115-\mathrm{D}$ & -- \\
\hline
\end{tabular}


Table 2-2 LFI Investigation Activities for 100-HR-1 Operable Unit High-Priority Sites (page 1 of 2)

\begin{tabular}{|c|c|c|c|}
\hline Site & Name - Size & Comments & $\begin{array}{l}\text { LFI Investigative } \\
\text { Approach }\end{array}$ \\
\hline $116-\mathrm{H}-1$ & $\begin{array}{l}\text { Process Effluent Disposal } \\
\text { Trench }-91 \mathrm{~m} \times 30 \mathrm{~m} \times 4.6 \mathrm{~m} \\
\text { deep }\end{array}$ & $\begin{array}{l}\text { Received high activity effluent produced } \\
\text { by ruptured fuel elements. Received } \\
\text { sludge from } 116-\mathrm{H}-7 \text { retention basin } \\
\text { when } 100-\mathrm{H} \text { Area was deactivated. Also } \\
\text { received } 90 \mathrm{~kg} \text { of sodium dichromate. }\end{array}$ & $B, C, F, G, H, P$ \\
\hline 116-H-2 & $\begin{array}{l}\text { Effluent Disposal Trench - } \\
84 \mathrm{~m} \times 30 \mathrm{~m} \times 1.8 \mathrm{~m} \text { deep }\end{array}$ & $\begin{array}{l}\text { Received decontamination wastes from } \\
\text { the } 132-\mathrm{H}-3 \text { effluent pumping station } \\
\text { during reactor shutdown and standby } \\
\text { periods. Received } 600 \mathrm{~kg} \text { of sodium } \\
\text { dichromate. }\end{array}$ & B, C, F, G, H, R \\
\hline $116-\mathrm{H}-3$ & $\begin{array}{l}\text { Dummy Decontamination } \\
\text { French Drain }-0.9 \mathrm{~m} \text { diameter } \\
\times 4.6 \mathrm{~m} \text { deep }\end{array}$ & $\begin{array}{l}\text { Received wastes generated during } \\
\text { decontamination of fuel-element spacers. } \\
\text { Received } 2000 \mathrm{~kg} \text { of sodium dichromate, } \\
\text { sodium oxalate, and sodium sulfamate. }\end{array}$ & B, C, F, G, H \\
\hline 116-H-7 Basin & $\begin{array}{l}\text { Process Effluent Retention } \\
\text { Basin }-183 \mathrm{~m} \times 83 \mathrm{~m} \times 6 \mathrm{~m} \\
\text { deep }\end{array}$ & $\begin{array}{l}\text { Held cooling water effluent from } \mathrm{H} \\
\text { reactor for cooling/decay before release } \\
\text { to the Columbia River, large leaks of } \\
\text { effluent to the soil. }\end{array}$ & B, C, F, H \\
\hline $116-\mathrm{H}-9$ & $\begin{array}{l}\text { Confinement Seal Pit Drainage } \\
\text { Crib }-3 m \times 3 m \times 3 m \text { deep }\end{array}$ & $\begin{array}{l}\text { Received } 300,000 \text { liters of waste from } \\
\text { the } 132-\mathrm{H}-2 \text { reactor exhaust air filter } \\
\text { building seal pits. }\end{array}$ & B, C, F, G, H \\
\hline $116-\mathrm{H}-5$ & $\begin{array}{l}\text { Process Effluent Outfall } \\
\text { Structure }-115 \mathrm{~m} \times 8 \mathrm{~m} \times 4 \mathrm{~m}\end{array}$ & $\begin{array}{l}\text { Discharged cooling water effluent to } \\
\text { bottom center of Columbia River through } \\
\text { effluent pipeline from sump or at shore } \\
\text { using spillway. }\end{array}$ & $A B, A C, A F, A G$ \\
\hline $\begin{array}{l}\text { Process } \\
\text { Effluent } \\
\text { Pipelines }\end{array}$ & $\begin{array}{l}\text { Total Length approx. } 610 \mathrm{~m} \text {, } \\
\text { pipe diameter } 152 \mathrm{~cm} \text {, buried } \\
6 \mathrm{~m} \text { below surface }\end{array}$ & $\begin{array}{l}\text { Transported reactor cooling water from } \\
\text { reactors to retention basins, outfall } \\
\text { structures, and } 116-\mathrm{H}-1 \text { trench, leaked } \\
\text { effluent to soil, contains contaminated } \\
\text { sludge and scale. }\end{array}$ & $\mathrm{H}, \mathrm{T}$ \\
\hline 116-H-7 Trench & $\begin{array}{l}\text { Sludge Burial Trench - } \\
\text { unknown dimensions }\end{array}$ & $\begin{array}{l}\text { Received sludge from the } 116-\mathrm{H}-7 \\
\text { process effluent retention basin. }\end{array}$ & $\mathbf{H}$ \\
\hline $132-\mathrm{H}-3$ & $\begin{array}{l}\text { Effluent Pumping Station -- } \\
\text { Four concrete sumps with } \\
300,000 \text { liter capacity }\end{array}$ & $\begin{array}{l}\text { Collected and pumped water from the } \mathrm{H} \\
\text { reactor drains, including the irradiated } \\
\text { fuel storage drains, into the } 116-\mathrm{H}-7 \\
\text { process effluent retention basin. Water } \\
\text { and sludge in sumps was removed before } \\
\text { station was demolished in place and } \\
\text { covered with } 5 \mathrm{~m} \text { of fill. }\end{array}$ & $\mathrm{H}$ \\
\hline 132-H-2 & $\begin{array}{l}\text { Exhaust Air Filter Building - } \\
18 \mathrm{~m} \times 12 \mathrm{~m} \times 11 \mathrm{~m} \text { high }\end{array}$ & $\begin{array}{l}\text { Contaminated building demolished in } \\
\text { place, buried, covered with } 5 \mathrm{~m} \text { fill. } \\
\text { Building was built on the site of the } \\
\text { demolished and removed } 116-\mathrm{H}-4 \text { pluto } \\
\text { crib. }\end{array}$ & $\mathrm{H}$ \\
\hline
\end{tabular}




\section{Table 2-2 LFI Investigation Activities for 100-HR-1 Operable Unit High-Priority Sites (page 1 of 2)}

\begin{tabular}{|c|c|c|c|}
\hline Site & Name - Size & Comments & $\begin{array}{l}\text { LFI Investigative } \\
\text { Approach }\end{array}$ \\
\hline $132-\mathrm{H}-1$ & $\begin{array}{l}\text { Reactor Exhaust Stack - } 61 \mathrm{~m} \\
\text { high x } 5 \mathrm{~m} \text { diameter (now } \\
\text { demolished) }\end{array}$ & $\begin{array}{l}\text { Contaminated stack demolished in place, } \\
\text { buried, covered with Im fill. }\end{array}$ & $\mathbf{H}$ \\
\hline $116-\mathrm{H}-4$ & $\begin{array}{l}\text { Pluto Crib }-1.2 \mathrm{~m} \times 1.2 \mathrm{~m} \times \\
0.6 \mathrm{~m} \text { deep }\end{array}$ & $\begin{array}{l}\text { Received cooling water discharge } \\
\text { contaminated by failed fuel elements. } \\
\text { Received } 1000 \mathrm{~kg} \text { of sodium dichromate. } \\
\text { Crib was excavated and the material was } \\
\text { buried in the } 118-\mathrm{H}-5 \text { burial ground. } \\
132-\mathrm{H}-2 \text { exhaust air filter building was } \\
\text { later built on the same site. }\end{array}$ & $\mathbf{H}$ \\
\hline \multicolumn{4}{|c|}{$\begin{array}{l}\text { AB = Vadose zone borehole - drilling, geologic logging, and sampling at an analogous site in the } 100 \text { Area } \\
\text { AC = Chemical and radionuclide information from analogous site in the } 100 \text { Area } \\
\text { AF = Field screening for radioactivity and volatile organic compounds at an analogous site in the } 100 \text { Area } \\
\text { AG = Borehole spectral gamma-ray geophysical log at an analogous site in the } 100 \text { Area } \\
B=\text { Vadose zone borehole - drilling, geologic logging, and sampling } \\
C=\text { Chemical and radionuclide analysis of samples } \\
F=\text { Field screening for radioactivity and volatile organic compounds } \\
G=\text { Borehole spectral gamma-ray geophysical log } \\
H=\text { Analysis of historical data including prior sampling and radiological analysis } \\
P=\text { Physical properties analysis of samples } \\
\mathbf{R}=\text { Ground penetrating radar to position boreholes } \\
T=\text { Radiological analysis using small remote controlled tracked vehicle }\end{array}$} \\
\hline
\end{tabular}


DOE/RL-93-51, Rev. 0

Table 2-3 Borehole Expected Waste Depths ${ }^{\mathrm{a}}$

\begin{tabular}{||c|c|c|c|c||}
\hline \multirow{2}{*}{ Borehole Number } & \multicolumn{2}{|c|}{$\begin{array}{c}\text { Expected Waste Depth } \\
\text { (below ground surface) }\end{array}$} & \multicolumn{2}{|c|}{$\begin{array}{c}\text { Estimated Depth to } \\
\text { Groundwater }\end{array}$} \\
\cline { 2 - 5 } & $(\mathrm{ft})$ & $(\mathbf{m})$ & $(\mathrm{ft})$ & $(\mathrm{m})$ \\
\hline \hline $116-\mathrm{H}-1$ & 10 & 3 & 55 & 16.8 \\
\hline $116-\mathrm{H}-2$ & 10 & 3 & 35 & 10.7 \\
\hline $116-\mathrm{H}-3$ & 15 & 4.6 & 35 & 10.7 \\
\hline $116-\mathrm{H}-7$ & 10 & 3 & 55 & 16.8 \\
\hline $116-\mathrm{H}-9$ & 10 & 3 & 35 & 10.7 \\
\hline
\end{tabular}

aWHC, 1991c. 
Table 2-4 Vadose Zone Boreholes-Sample Collection Information

\begin{tabular}{|c|c|c|c|c|c|c|}
\hline Location" & $\begin{array}{l}\text { Sample } \\
\text { Number }\end{array}$ & Depth (ft) & $\begin{array}{c}\text { Sample } \\
\text { Type }\end{array}$ & Laboratory & $\begin{array}{c}\text { Date } \\
\text { Sampled }\end{array}$ & Comments \\
\hline \multirow{7}{*}{$\begin{array}{l}116-\mathrm{H}-1 \\
\text { (N95,039.4; } \\
\text { W38,608.8) }\end{array}$} & B05WV5 & $10.0-12.0$ & Soil & TMA & $3 / 9 / 92$ & \\
\hline & B05WV6 & $13.6-15.6$ & Soil & TMA & $3 / 9 / 92$ & \\
\hline & B05WV7 & $13.6-15.6$ & Soil & WESTON & $3 / 9 / 92$ & $\begin{array}{l}\text { Split with } \\
\text { B05WV6 }\end{array}$ \\
\hline & B05WV8 & $15.0-17.0$ & Soil & TMA & $3 / 9 / 92$ & \\
\hline & BosWV9 & $16.5-17.8$ & Soil & TMA & $3 / 10 / 92$ & \\
\hline & BosWWO & $19.3-20.8$ & Soil & TMA & $3 / 11 / 92$ & \\
\hline & B05WW4 & $24.0-25.1$ & Soil & TMA & $3 / 11 / 92$ & \\
\hline \multirow{3}{*}{$\begin{array}{l}\text { 116-H-2 } \\
\text { (N94,866.9; } \\
\text { W39,714.3) }\end{array}$} & B05WW5 & $9.9-12.1$ & Soil & TMA & $3 / 13 / 92$ & \\
\hline & B05WW6 & $14.9-17.2$ & Soil & TMA & $3 / 16 / 92$ & \\
\hline & B05WW7 & $14.9-17.2$ & Soil & TMA & $3 / 16 / 92$ & $\begin{array}{c}\text { Duplicate with } \\
\text { B05WW6 }\end{array}$ \\
\hline \multirow{2}{*}{$\begin{array}{l}\text { 116-H-3 } \\
\text { (N95,129.6; } \\
\text { W39,372.4) }\end{array}$} & B05WP1 & $14.5-16.3$ & Soil & TMA & $3 / 4 / 92$ & \\
\hline & B05WP5 & $19.6-21.7$ & Soil & TMA & $3 / 5 / 92$ & \\
\hline \multirow{5}{*}{$\begin{array}{l}116-\mathrm{H}-7 \\
\text { (N95,429.8; } \\
\text { W38,515.3) }\end{array}$} & B05WT8 & $1.0-3.0$ & Soil & TMA & $2 / 27 / 92$ & \\
\hline & B05WT9 & $8.0-10.0$ & Soil & TMA & $2 / 28 / 92$ & \\
\hline & B05WV2 & $9.8-12.4$ & Soil & TMA & $3 / 2 / 92$ & \\
\hline & B05WV3 & $14.8-16.4$ & Soil & TMA & $3 / 2 / 92$ & \\
\hline & B05WV4 & $19.2-20.8$ & Soil & TMA & $3 / 2 / 92$ & \\
\hline \multirow{3}{*}{$\begin{array}{l}\text { 116-H-9 } \\
\text { (N95,055.9; } \\
\text { W40,107.2) }\end{array}$} & B05WN8 & $3.1-5.3$ & Soil & TMA & $2 / 26 / 92$ & \\
\hline & B05WN9 & $17.6-20.1$ & Soil & TMA & $2 / 27 / 92$ & \\
\hline & B05WP0 & $21.7-24.2$ & Soil & TMA & $2 / 27 / 92$ & \\
\hline
\end{tabular}

aHanford site coordinates of borehole in parentheses.

${ }^{\text {'TMA }}$ = Thermo Analytical Laboratories, Richmond, California.

WESTON = Weston Laboratory, Lionville, Pennsylvania. 
DOE/RL-93-51, Rev. 0

Table 2-5 Septic Tanks-Sample Collection Information

\begin{tabular}{|c|c|c|c|c|c|}
\hline Location & $\begin{array}{l}\text { Sample } \\
\text { Number }\end{array}$ & $\begin{array}{c}\text { Sample } \\
\text { Type }\end{array}$ & Laboratory ${ }^{a}$ & Date Sampled & Comments \\
\hline \multirow[t]{7}{*}{$1607-\mathrm{H}-2$} & Bo0ZM6 & Sludge & TMA & $6 / 25 / 91$ & \\
\hline & BoOZM7 & Sludge & TMA & $6 / 25 / 91$ & \\
\hline & 801605 & Liquid & TMA & $6 / 25 / 91$ & \\
\hline & B01606 & Liquid & TMA & $6 / 25 / 91$ & \\
\hline & B01607 & Liquid & TMA & $6 / 25 / 91$ & \\
\hline & B01608 & Liquid & TMA & $6 / 25 / 91$ & \\
\hline & B01609 & Liquid & TMA & $6 / 25 / 91$ & \\
\hline \multirow[t]{6}{*}{$1607-\mathrm{H}-4$} & B07206 & Soil & TMA & $8 / 3 / 92$ & \\
\hline & B07207 & Soil & WESTON & $8 / 3 / 92$ & Split with B07206 \\
\hline & B07208 & Soil & TMA & $8 / 3 / 92$ & $\begin{array}{c}\text { Duplicate with } \\
\text { B07206 }\end{array}$ \\
\hline & B07209 & Soil & TMA & $8 / 3 / 92$ & Trip Blank \\
\hline & B07210 & Soil & WESTON & $8 / 3 / 92$ & Trip Blank \\
\hline & B07211 & Soil & TMA & $8 / 3 / 92$ & \\
\hline
\end{tabular}

${ }^{\text {a }}$ TMA = Thermo Analytical Laboratories, Richmond, California. WESTON = Weston Laboratory, Lionville, Pennsylvania. 
DOE/RL-93-51, Rev. 0

Table 2-6 Electrical Facilities-PCB Sample Collection Information

\begin{tabular}{||l|c|c|c|c|c||}
\hline \multicolumn{1}{|c|}{ Location } & $\begin{array}{c}\text { Sample } \\
\text { Number }\end{array}$ & $\begin{array}{c}\text { Sample } \\
\text { Type }\end{array}$ & Laboratory $^{2}$ & $\begin{array}{c}\text { Date } \\
\text { Sampled }\end{array}$ & Comments \\
\hline \hline 105-H & B018S5 & Soil & DCHM & $12 / 09 / 91$ & \\
\hline $\begin{array}{l}\text { 151-H, South of South } \\
\text { Large Pad }\end{array}$ & B018S6 & Soil & DCHM & $12 / 09 / 91$ & \\
\hline $\begin{array}{l}\text { 151-H, South of South } \\
\text { Large Pad }\end{array}$ & B018S7 & Soil & DCHM & $12 / 09 / 91$ & $\begin{array}{c}\text { Duplicate w/ } \\
\text { B018S6 }\end{array}$ \\
\hline $\begin{array}{l}\text { 151-H, South of South } \\
\text { Large Pad }\end{array}$ & B018S8 & Soil & S $^{3}$ & $12 / 09 / 91$ & $\begin{array}{c}\text { Split w/ } \\
\text { B018S6 }\end{array}$ \\
\hline \begin{tabular}{l} 
151-H, South \\
\hline $151-H$, Southwest
\end{tabular} & B018S9 & Soil & DCHM & $12 / 09 / 91$ & \\
\hline 151-H, West Center 151-H & B018T1 & Soil & DCHM & $12 / 09 / 91$ & \\
\hline $\begin{array}{l}\text { 151-H, Between North } \\
\text { Pylons }\end{array}$ & B018T2 & Soil & DCHM & $12 / 09 / 91$ & \\
\hline
\end{tabular}

a DCHM = Data Chem Laboratories.

$S^{3}=$ Maxwell Laboratories, S-Cubed Division. 


\subsection{INVESTIGATION RESULTS AND CONCLUSIONS}

This chapter presents results and conclusions from background sampling and the LFI results for each of the sites investigated. Section 3.1 discusses the background sampling. Sections 3.2 through 3.6 presents the results of the intrusive investigation at five high-priority sites. Section 3.7 presents the results of non-intrusive investigations at the rest of the high-priority sites. Section 3.8 presents the results of the investigations at the low-priority sites. Section 3.9 provides a summary of potential ARARs for the 100-HR-1 Operable Unit.

The following types of data are presented in discussions of the sites:

- $\quad$ site location, size, characteristics, history, and expected contaminants

- geologic data obtained during the investigation

- analytical results from off-site laboratories including analyses of inorganic contaminants (metals), VOCs, SVOCs, pesticides, PCBs, and on-site laboratory analyses of physical properties

- radionuclide analytical results from off-site laboratories

- $\quad$ field screening data collected using hand-held instruments during sampling

- borehole spectral gamma geophysical logging results

- analysis of data collected at sites that are analogous to 100-HR-1 sites by other 100 Area source operable unit LFIs

- results of the comparison of data collected during the 1992 LFI and historical data from previous investigations at the site

- concentrations of Sr-90 and Tc-99 and gross alpha levels in groundwater from monitoring wells near the high-priority sites are reviewed to assess the potential impact on groundwater in the groundwater uppermost unconfined aquifer. These data were obtained during the 100-HR-3 Operable Unit LFI. ${ }^{1}$

\footnotetext{
${ }^{1}$ There are currently no waste or effluent discharges in the operable unit. Infiltration may be a driving force for movement of contaminants from the vadose zone to the saturated zone, however, the average annual precipitation and evapotranspiration are about equal (DOE-RL 1992a). Waste sites near the Columbia River (e.g., within $300 \mathrm{~m}$ ) may be affected by changes in groundwater elevations of the uppermost unconfined aquifer which is known to fluctuate in response to changes in river stage, and reversals of groundwater gradient are known to occur (DOE-RL 1992a). Contaminant transport modeling was not performed as part of the 100-HR-1 LFI or 100-HR-1 QRA. The data available are not sufficient to support such modeling, but are sufficient to support the conclusions made.
} 
Conclusions reached about each site are also presented in this chapter.

\subsection{BACKGROUND SAMPLING}

\subsubsection{General Hanford Sitewide Background Data}

The natural soil composition at the Hanford Site has been reported in previous studies (DOE-RL 1993a). The characterization effort involved the determination of the types and concentrations of nonradioactive analytes that exist naturally in the soils on the Hanford Site. The Hanford sitewide approach to chemical background levels of soils is based on the premise that all waste sites are part of a common sequence of vadose zone sediments, and the basic characteristics that control the chemical composition of the sediments are similar throughout the Hanford Site. The range of natural soil compositions was used to establish a single set of soil background data to identify inorganic contaminants of potential concern (COPC), a necessary step in the environmental restoration process.

Based on the data presented in the Hanford Site background report (DOE-RL 1993a), a table of the $95 \%$ UTL, based on a lognormal distribution, for inorganic analytes was generated (Table 3-1). This table is used as a screening tool to identify potential contaminants of concern in both the QRA (WHC 1993a) and this LFI report.

Hanford sitewide background levels for organic and radionuclide analytes are not included in the Hanford Site background report (DOE-RL 1993a). Any detection of organic compound above the contract required quantitation limits is considered a COPC. Any radionuclide detected above the laboratory required detection limit (from Appendix A of the RFI/CMS work plan, DOE-RL 1992a) is considered a COPC.

\subsubsection{Local Background Data}

No specific background data exist for the 100-HR-1 Source Operable Unit. Local background sampling of ambient air concentrations was performed during the drilling of the five vadose zone boreholes in order to determine the background levels for radioactivity and VOCs during field screening. The background levels for radioactivity taken in the field ranged from 50 to 75 counts per minute (cpm) using a Geiger-Mueller beta-gamma detector. The VOC background levels indicated concentrations at less than detectable limits. These background levels were taken daily at a background site located generally north of the operable unit, near the river, and outside of the 100-HR-1 Source Operable Unit site.

\subsection{6-H-1 PROCESS EFFLUENT DISPOSAL TRENCH}

The 116-H-1 process effluent disposal trench was located directly south of the 116- $\mathrm{H}-7$ retention basin, in the southeast corner of the 100-HR-1 Source Operable Unit 
(Figure 2-1). It was approximately $300 \mathrm{ft}(91 \mathrm{~m})$ long, $100 \mathrm{ft}(30 \mathrm{~m})$ wide, and $15 \mathrm{ft}$ (4.6 m) deep (DOE-RL 1991b). From 1952 to 1954, the trench served as an emergency disposal crib for process effluent contaminated by fuel element ruptures. Radionuclide contaminants in this effluent included fission products such as Sr-90, Tc-99, Cs-134, Cs-137, Eu-152, Eu-154, Eu-155, and transuranics such as Pu-238, Pu-239, Pu-240, and Am-241. When ruptures occurred, process effluent was diverted from the 116-H-7 retention basin to this facility to prevent direct discharge of the highly contaminated waste stream to the Columbia River. After 1954, the trench was no longer used for process effluent. In 1965, when the $100 \mathrm{H}$ Area was deactivated, sludge taken from the 116- $\mathrm{H}-7$ retention basin was disposed of in the trench. Currently, the site is covered with clean gravel.

In addition to radionuclide contamination from the 116- $\mathrm{H}-7$ retention basin sludge, approximately 200 pounds $(\mathrm{lb})$ (90 kilograms [kg]) of sodium dichromate were disposed of (mixed with effluent water) in the $116-\mathrm{H}-1$ trench over its lifetime.

\subsubsection{Geology}

This site is characterized by sandy gravel fill to a depth of $13.6 \mathrm{ft}(4.1 \mathrm{~m})$ bgs. Below the fill is gravel and sand from 13.6 to $25.7 \mathrm{ft}(4.1$ to $7.8 \mathrm{~m}) \mathrm{bgs}$, the total depth of the borehole. The contact between the fill material and the native soil is characterized by a change in soil color and particle size distribution (Figure 3-1).

\subsubsection{Soil Samples}

3.2.2.1 Chemical Analysis. Laboratory analysis results of soil samples taken between 10 and $17.8 \mathrm{ft}$ bgs indicated three inorganic contaminants above the $95 \%$ UTL level. These contaminants were As, found between 10 and $15.6 \mathrm{ft}(3.0$ and $4.8 \mathrm{~m}) \mathrm{bgs} ; \mathrm{Cr}$, found between 16.5 and $17.8 \mathrm{ft}(5.0$ and $5.4 \mathrm{~m}) \mathrm{bgs}$; and $\mathrm{Pb}$, found between 10 and $17.8 \mathrm{ft}(3.0$ and $5.4 \mathrm{~m})$ bgs. Samples taken above $10 \mathrm{ft}(3.0 \mathrm{~m})$ and below $17.8 \mathrm{ft}(5.4 \mathrm{~m})$ did not contain elevated levels of inorganic analytes. Table 3-2 shows the contaminant levels at the various depths.

The VOC and SVOC contaminants detected in the samples taken from the 116- $\mathrm{H}-1$ vadose zone borehole are presented in Tables 3-3 and 3-4. The VOCs presented in Table 3-3 are typical of laboratory contaminants. None of these typical laboratory contaminants were detected in the laboratory blank or the split sample associated with the sample taken between 13.6 and $15.6 \mathrm{ft}$. The analytical data for the sample taken between 10.0 and $12.0 \mathrm{ft}$ were not validated, and no laboratory blanks are associated with it. Other sets of samples analyzed at the same laboratory during the same time period did have these analytes detected in their associated laboratory blanks. It is probable that these detections of acetone, methylene chloride, and toluene are laboratory anomalies.

Eleven semi-volatile polynuclear aromatics (PNA) were detected (Table 3-4). The source of these PNA contaminants is unclear, since the contaminants are not generally 
associated with the processes that generate the wastes disposed of in the 116-H-1 trench. However, the PNAs may be associated with coal tars (sometimes used to coat pipes to control corrosion) or creosote (commonly used as a wood preservative) (Ekambaram et al. 1988). borehole.

No pesticides were detected in the soil samples taken from the 116-H-1 vadose zone

The complete results of the chemical analyses for the samples taken from the $116-\mathrm{H}-1$ borehole are presented in Table A-1, Appendix A.

3.2.2.2 Radionuclide Analysis. The results of the radionuclide analysis of the soil samples taken from the 116-H-1 vadose zone borehole are presented in Table 3-5. The highest concentrations of radionuclide contamination are generally found in samples taken from between 10 and $17.8 \mathrm{ft}(3.0$ and $5.4 \mathrm{~m})$ bgs and include Co-60, Sr-90, Tc-99, Cs-137, Eu-152, and Eu-154. The complete results of the radionuclide analyses for the samples taken from the 116- $\mathrm{H}-1$ borehole are presented in Table A-6, Appendix A.

3.2.2.3 Field Screening. Continuous field screening for VOCs and radionuclides was performed at each of the five vadose zone boreholes by the field geologist. Volatile organic compound screening was performed using an OVM, while radionuclide screening was performed with a Geiger-Mueller instrument. No VOC concentrations above the action level (10 ppm above background) were detected during the drilling and sampling of the 116-H-1 borehole. Radionuclide screening found activity above the action level (twice the background level of $50 \mathrm{cpm})$ from $13.6 \mathrm{ft}$ to $18.9 \mathrm{ft}(4.1$ to $5.8 \mathrm{~m}) \mathrm{bgs}$. The field screening values are shown in Figure 3-2 and range from 85 to $1500 \mathrm{cpm}$, with the peak being at a depth of $16.5 \mathrm{ft}(5.0 \mathrm{~m})$.

3.2.2.4 Geophysical Borehole Logging. Geophysical logging using a spectral gamma-ray system was performed on the vadose zone boreholes included in this LFI. The results of the logging on the 116- $\mathrm{H}-1$ borehole indicated the presence of $\mathrm{Co}-60 \mathrm{from} 9$ to $17 \mathrm{ft}$ (2.7 to $5.2 \mathrm{~m}$ ) bgs. The maximum Co- 60 decay activity detected was $30 \mathrm{pCi} / \mathrm{g}$ at a depth of $15 \mathrm{ft}$. Cesium-137 was detected from the surface to a depth of $18 \mathrm{ft}(5.5 \mathrm{~m})$. The maximum Cs- 137 decay activity detected was $100 \mathrm{pCi} / \mathrm{g}$ at $15 \mathrm{ft}(4.8 \mathrm{~m})$ bgs. Europium-152 was encountered in the borehole survey from the surface to the maximum survey depth of $21 \mathrm{ft}(6.4 \mathrm{~m})$ bgs. The maximum Eu-152 decay activity was over $200 \mathrm{pCi} / \mathrm{g}$ between 14 and $16 \mathrm{ft}(4.3$ and $4.9 \mathrm{~m})$ bgs. Europium-154 was detected from 10 to $17 \mathrm{ft}(3.0$ to $5.2 \mathrm{~m}) \mathrm{bgs}$, with a peak activity of $60 \mathrm{pCi} / \mathrm{g}$ at $15 \mathrm{ft}(4.8 \mathrm{~m})$ bgs.

\subsubsection{Physical Properties Sample}

Three samples were taken in conjunction with the 116-H-1 borehole investigation for physical properties analysis. The samples were analyzed as described in Section 2.2. 
3.2.3.1 Sampling Data. Split tube samples were collected from borehole $116-\mathrm{H}-1$ at 12.7 to $13.7 \mathrm{ft}, 20.5$ to $21.5 \mathrm{ft}$, and 24.5 to $25.5 \mathrm{ft}$ bgs. The first sample was taken from material described by the field geologist as sandy gravel fill. The second sample was taken in a sandy gravel material below the fill. The third sample was taken at the bottom of the hole in gravelly sand. All three samples were collected in the vadose zone and all samples were described as dry.

3.2.3.2 Discussion of Physical Properties. Laboratory sieve analyses showed that the sediment grain size in the 12.7 to $13.7 \mathrm{ft}$ interval consisted of $59 \%$ gravel, $24 \%$ sand, and $17 \%$ silt and clay. The sediment grain size in the 20.5 to $21.5 \mathrm{ft}$ interval consisted of $47 \%$ gravel, $42 \%$ sand, and $11 \%$ silt and clay. The sediment grain size in the 24.5 to $25.5 \mathrm{ft}$ interval consisted of $42 \%$ gravel, $43 \%$ sand, and $15 \%$ silt and clay. The specific gravity was determined for both the coarse and fine fraction of the samples. The average specific gravity for the three sample intervals was 2.73. The bulk density for each sample was 1.89 grams/cubic centimeter $(\mathrm{g} / \mathrm{cc}), 2.20 \mathrm{~g} / \mathrm{cc}$, and $2.02 \mathrm{~g} / \mathrm{cc}$ in order of increasing depth of sample.

The moisture content of the samples was $4.28 \%, 1.34 \%$, and $2.80 \%$ in order of increasing depth of the sample location.

The saturated hydraulic conductivity varied from $2.0 \mathrm{E}-04$ to $4.1 \mathrm{E}-04 \mathrm{~cm} / \mathrm{second}$; these values are quite low for sandy gravels. The low hydraulic conductivity could be the result of the high silt and clay content reported by the grain size analysis.

The porosity of the soil samples ranged from a low of $20.63 \%$ for the 20.5 to $21.5 \mathrm{ft}$ sample to a high of $30.73 \%$ for the 12.7 to $13.7 \mathrm{ft}$ sample with the 24.5 to $25.5 \mathrm{ft}$ sample having a porosity of $25.60 \%$.

\subsubsection{Conclusions}

The 116- $\mathrm{H}-1$ process effluent disposal trench area is contaminated with both inorganic (As, $\mathrm{Cr}$, and $\mathrm{Pb}$ ) and SVOC contaminants (PNAs) as well as man-made radionuclides. Based on both the LFI data and the historical data (Dorian and Richards 1978), the contamination appears to be limited to a depth of $23 \mathrm{ft}(7.0 \mathrm{~m}) \mathrm{bgs}$. The levels of radionuclide contamination detected as a result of the LFI are approximately an order of magnitude less than the levels that were previously reported by Dorian and Richards (1978) (Table 3-5). Figure 3-1 compares the various types of LFI data that were collected for the 116-H-1 disposal trench and the historical data. Since the historical data are limited to radionuclide analysis only, a direct comparison of LFI inorganic or organic contaminant data is not possible.

Based upon operational histories of the reactor sites in the 100 Area, three sites analogous to the $116-\mathrm{H}-1$ site are located in other 100 Area source operable units have been examined thus far by LFIs. These are 116-DR-1, 116-DR-2, and 116-B-1. To assess the concept that these sites are analogous, a comparison of radionuclide and chemical analytical 
results from the LFI samples was performed. The analytical data are compiled in the LFI reports for each operable unit (DOE-RL 1993c and DOE-RL 1993e). The radionuclide contaminants present in samples from the four sites are similar. Chromium is a contaminant, i.e., present in concentrations greater than the $95 \%$ UTL, in three of the four sites.

Chromium is not a contaminant at the 116-DR-2 site, but $\mathrm{Ag}$ and $\mathrm{Cd}$ are. At site 116-DR-1, $\mathrm{Ag}$ and $\mathrm{Cr}$ are contaminants. Lead was not found to be a contaminant at any of the other sites. Volatile organic compounds were found at all four sites. The compounds detected are toluene, acetone, and methylene chloride. Semi-volatile compounds were detected in three of the four sites, but there was little consistency of compounds between the sites. No PCBs or pesticides were found at the four sites.

\subsubsection{Groundwater Assessment}

Monitoring wells H4-13 and H4-45, constructed and sampled as part of the 100-HR-3 Groundwater Operable Unit LFI (DOE-RL 1993d), have elevated levels of Sr-90 relative to upgradient wells (33 and $13 \mathrm{pCi} / \mathrm{L}$, respectively). These two wells are located northeast (side gradient) of the 116- $\mathrm{H}-1$ process effluent disposal trench (see Figure 3-2 for locations). The 116-H-1 site had elevated levels of Sr-90 detected in the soil. There is no clear indication that the site is having a current impact to the groundwater.

\subsection{6-H-2 EFFLUENT DISPOSAL TRENCH}

The 116-H-2 trench is situated outside the $\mathrm{H}$ Reactor building security fence in the far southwestern corner of the 100-HR-1 Source Operable Unit, directly south of the H Reactor building (Figure 2-1). The trench measures $275 \mathrm{ft}(84 \mathrm{~m})$ long, $100 \mathrm{ft}(30 \mathrm{~m})$ wide, and $6 \mathrm{ft}$ $(1.8 \mathrm{~m})$ deep. Decontamination wastes generated during reactor shutdown and standby periods were disposed of in this unit. The wastes were collected in the 132-H-3 effluent pumping station sumps and pumped to the 116-H-2 disposal trench. The trench was used from 1953 until its retirement in 1965, at which time it was covered to grade with soil (Stenner et al. 1988). Approximately $1,300 \mathrm{lb}(600 \mathrm{~kg})$ of sodium dichromate were disposed of in this trench.

\subsubsection{Geology}

This site is characterized by gravelly sand fill (approximately $20 \%$ gravel) to a depth of $12.2 \mathrm{ft}(3.7 \mathrm{~m})$ bgs. From 12.2 to $18.2 \mathrm{ft}(3.7$ to $5.5 \mathrm{~m}) \mathrm{bgs}$ (the total depth of the borehole) the material is sandy gravel, with up to $60 \%$ gravel (Figure 3-3). All the material encountered during drilling is probably fill material. 


\subsubsection{Soil Samples}

3.3.2.1 Chemical Analysis. The laboratory analysis of samples taken from the $116-\mathrm{H}-2$ borehole did not indicate any inorganic contaminant concentrations above the $95 \%$ UTL. There were no VOCs, SVOCs, or pesticide contaminant detections. The complete results of the chemical analyses for the samples taken from the 116-H-2 borehole are presented in Table A-2, Appendix A.

3.3.2.2 Radionuclide Analysis. In the soil samples taken from the borehole, four radionuclides were detected; Ra-226, Th-228, Th-232, and U-238. The concentrations of these radionuclides are very low as shown in Table 3-6. The complete results of the radionuclide analyses for the samples taken from the 116- $\mathrm{H}-2$ borehole are presented in Table A-7, Appendix A.

3.3.2.3 Field Screening. During continuous field screening of the 116-H-2 borehole, no VOC concentrations above the action level ( $10 \mathrm{ppm}$ above background) were detected, nor was radionuclide activity above the background level of $50 \mathrm{cpm}$ detected.

3.3.2.4 Geophysical Borehole Logging. Logging with a spectral gamma-ray system was performed on the 116-H-2 borehole. No man-made radionuclides (Co-60, Cs-137, Eu-152, and $\mathrm{Eu}-154)$ were detected in the borehole.

\subsubsection{Conclusions}

The 116- $\mathrm{H}-2$ effluent disposal trench does not contain any inorganic contaminants above the 95\% UTL, nor organic or pesticide contaminants. Small amounts of radionuclides (naturally occurring isotopes) were detected. However, Dorian and Richards (1978) reported radionuclide contamination (including $\mathrm{H}-3$, Co-60, Sr-90, Cs-137, Eu-152, Eu-154, Eu-155) of up to $77 \mathrm{pCi} / \mathrm{g}$ at depths of 1 to $10 \mathrm{ft}(0.3$ to $3.0 \mathrm{~m})$ bgs at this site. This historical data are inconsistent with the LFI data reported here. Figure 3-3 presents a comparison of the various types of LFI data that were collected for the 116-H-2 disposal trench.

The vadose zone borehole was drilled in the southwest corner of the 116- $\mathrm{H}-2$ site. This location was chosen based on discussions at meetings with regulators that considered lateral extent of the site, access, etc. It is possible that a second borehole, located near the center of the trench, would detect contamination at similar levels to that detected by Dorian and Richards (1978).

Sample analysis does not indicate the presence of sodium dichromate in the soil column. The contaminant may have been flushed through the soil to the groundwater, or as discussed above, the lack of detection may be associated with the borehole location.

There are no directly analogous sites to the 116- $\mathrm{H}-2$ effluent disposal trench. 
No specific conclusions can be drawn concerning the level of contamination at this site due to the inconsistency between the results of the field data and the historical data. The historical data were used in the development of the QRA to be conservative. The inconsistencies between the field and historical data do not assist in generating an accurate conceptual model of the site.

\subsubsection{Groundwater Assessment}

Results from sampling at monitoring well $\mathrm{H} 4-46$, located down gradient from the 116-H-2 site (see Figure 3-2 for well location), did not indicate any Sr-90, Tc-99, or gross alpha contamination. The 116- $\mathrm{H}-2$ site does not appear to be having an impact on the groundwater.

\subsection{6-H-3 DUMMY DECONTAMINATION FRENCH DRAIN}

The 116-H-3 dummy decontamination French drain is a vertical leaching drain located within the $\mathrm{H}$ Reactor building security fence, directly east of the reactor building (Figure 2-1). The drain is $3 \mathrm{ft}(0.9 \mathrm{~m})$ in diameter, approximately $15 \mathrm{ft}(4.6 \mathrm{~m})$ deep and is made of vitreous tile conduit. From 1950 to 1965 , wastes generated during decontamination of fuel-element spacers were transferred to this drain for disposal. Approximately $4,400 \mathrm{lb}$ $(2,000 \mathrm{~kg})$ each of sodium dichromate, sodium oxalate, and sodium sulfamate were disposed of in the 116-H-3 drain (WHC 1993a). The drain is presently covered to grade with soil.

\subsubsection{Geology}

This site is characterized by sandy gravel fill to a depth of approximately $21.7 \mathrm{ft}$ $(6.6 \mathrm{~m}) \mathrm{bgs}$, the total depth of the borehole. A minor change in soil color occurs between 6 and $10 \mathrm{ft}(1.8$ and $3.0 \mathrm{~m})$ bgs, but there is not enough change in other soil properties to determine if there is a fill/native soil contact represented here (Figure 3-4). All the material encountered in the borehole may be fill material.

\subsubsection{Soil Samples}

3.4.2.1 Chemical Analysis. The laboratory analysis of samples taken from the $116-\mathrm{H}-3$ vadose zone borehole (located near the southeast corner of the 116-H-3 site) showed no inorganic contaminant levels above the $95 \%$ UTL. There were no VOC, SVOC, or pesticide contaminants detected. The complete results of the chemical analyses for the samples taken from the 116-H-3 borehole are presented in Table A-3, Appendix A.

3.4.2.2 Radionuclide Analysis. Seven radionuclides were detected in the soil samples from the 116-H-3 borehole (see Table 3-7). The radionuclides detected were Co-60, 
Eu-152, Ra-226, Th-228, Th-232, U-233/234, and U-238. All were detected at levels of $<1 \mathrm{pCi} / \mathrm{g}$. The complete results of the radionuclide analyses for the samples taken from the 116-H-3 borehole are presented in Table A-8, Appendix A.

3.4.2.3 Field Screening. No levels of VOCs above the action level ( $10 \mathrm{ppm}$ above background) were detected during continuous field screening of the 116-H-3 borehole. There also was no radionuclide activity detected above the background level of $75 \mathrm{cpm}$.

3.4.2.4 Geophysical Borehole Logging. Logging was performed on the 116-H-3 borehole using a spectral gamma-ray system. Small amounts of man-made radionuclides (Co-60, $\mathrm{Eu}-152$, and Eu-154) were detected in the borehole. Cobalt-60 was encountered in two intervals in the survey; from the surface to $1 \mathrm{ft}(0.3 \mathrm{~m})$ and from $12 \mathrm{ft}(3.7 \mathrm{~m})$ to the maximum survey depth of $18 \mathrm{ft}(5.5 \mathrm{~m})$ bgs. The activity detected was $<1 \mathrm{pCi} / \mathrm{g}$. Similarly, Eu-152 was detected at activity levels of $<5 \mathrm{pCi} / \mathrm{g}$ in two intervals, from the surface to $1 \mathrm{ft}(0.3 \mathrm{~m})$ and from 11 to $18 \mathrm{ft}(3.6$ to $5.5 \mathrm{~m})$ bgs. Europium-154 was detected between 12 and $16 \mathrm{ft}(3.7$ and $4.9 \mathrm{~m})$ bgs. The detected activity was not continuous and was $<1 \mathrm{pCi} / \mathrm{g}$. Cesium-137 was not detected in the borehole.

\subsubsection{Conclusions}

There is no indication of inorganic or organic contamination at the 116-H-3 dummy decontamination french drain. There is, however, some indication of radionuclide contamination both near the surface and at depth at the site. One soil sample, the spectral gamma-ray borehole logging, and the historical data from Dorian and Richards (1978) indicate the presence of relatively small amounts of radionuclide contamination between approximately 12 and $18 \mathrm{ft}(3.7$ and $5.5 \mathrm{~m})$ bgs. The gamma-ray logs indicate traces of radionuclide contamination (Co-60 and Eu-152) near the surface. Figure 3-4 presents a comparison of the various types of LFI data that were collected for the 116- $\mathrm{H}-3$ drain and detections of contaminants from the historical data.

Sample analysis does not indicate the presence of the sodium dichromate in the soil column. The contaminant may have been flushed through the soil to the groundwater.

No sampling was performed at the analogous 116-B-4 dummy decontamination french drain site as part of an LFI, making comparison of LFI data at the two sites impossible. The historical data for both sites (Dorian and Richards 1978) are comparable with a similar list of radionuclides detected at each site and similar concentrations. Based on the historical data, radionuclides detected at both sites were Cs-137, Co-60, Eu-152, Eu-154, Eu-155, Pu-239, and Sr-90. 


\subsubsection{Groundwater Assessment}

Based on limited resuits from sampling at monitoring well $\mathrm{H} 4-47$, located down gradient from the 116-H-3 site (see Figure 3-2 for well location), the site does not appear to be having an impact to the groundwater.

\subsection{6-H-7 PROCESS EFFLUENT RETENTION BASIN}

The 116-H-7 process effluent retention basin is located in the southeast comer of the 100-HR-1 Source Operable Unit and is now enclosed within a chain-link security fence (Figure 2-1). This double-celled basin received process effluent (primarily cooling water effluent) from the H Reactor. The basin was $600 \mathrm{ft}(183 \mathrm{~m})$ long, $273 \mathrm{ft}(83.2 \mathrm{~m})$ wide, and $20 \mathrm{ft}(6 \mathrm{~m})$ deep (extending approximately $14 \mathrm{ft}$ above the ground surface) with a capacity of approximately $25,000,000$ gallons (gal) $(95,000,000 \mathrm{~L})$ (Stenner et al. 1988). It was designed to retain cooling water effluent to allow for radioactive decay and thermal cooling. The effluent was then discharged directly to the Columbia River. Decontamination wastes from the $\mathrm{H}$ Reactor building drains were also pumped to this basin by the $132-\mathrm{H}-3$ pumping station (DOE-RL 1992a).

Prior to changing to parallel operation of both basins in 1954, the reactor effluent was normally routed to just one of the two concrete-lined cells of the basin. In the event of a fuel-element cladding rupture, cooling water would come in direct contact with the fuel element. When this occurred, the water from the side of the basin that had received the contaminated effluent would be drained to the $116-\mathrm{H}-1$ trench (Section 3.2) for soil column disposal (Dorian and Richards 1978).

The basin was active from 1949 to 1965 . Sludge and waste from this basin were removed in 1953 and again in 1965 . The material removed in 1953 was placed in an adjacent trench (116-H-7 disposal trench). Some of the sludge removed in 1965 was placed in the 116-H-1 trench. The standing walls of the retention basin were demolished into the basin, and the basin has been backfilled with soil. The present depth to the bottom of the basin is approximately $6 \mathrm{ft}(2 \mathrm{~m})$.

\subsubsection{Geology}

This site is characterized by sandy gravel fill to a depth of $5.8 \mathrm{ft}(1.8 \mathrm{~m})$ bgs. From 5.8 to $8 \mathrm{ft}(1.8$ to $2.4 \mathrm{~m}) \mathrm{bgs}$, the concrete bottom of the retention basin is encountered. Approximately $6 \mathrm{ft}(1.8 \mathrm{~m})$ of sandy gravel fili is found under the concrete floor of the basin to a total depth of $13.8 \mathrm{ft}(4.0 \mathrm{~m})$. Sandy gravel, with intermittent silt layers, makes up the native soil found between 13.8 and $20.8 \mathrm{ft}(4.2$ and $6.3 \mathrm{~m}) \mathrm{bgs}$, the total depth of the borehole (Figure 3-5). 


\subsubsection{Soil Samples}

3.5.2.1 Chemical Analysis. Laboratory analysis results of a soil sample taken near the surface ( 1.0 to $3.0 \mathrm{ft}$ [0.3 to $0.9 \mathrm{~m}]$ bgs) indicated elevated levels (above the $95 \%$ UTL) of As and $\mathrm{Pb}$. Table 3-8 shows the contamination levels that were found. Samples taken below $3.0 \mathrm{ft}(0.9 \mathrm{~m})$ did not contain elevated levels of inorganic analytes.

The only VOC contaminant found in the 116-H-7 vadose zone borehole was toluene (Table 3-9). Toluene is a typical laboratory contaminant and the detection is probably a false positive detection. No SVOC or pesticide compounds were detected in the soil samples taken from the borehole. The complete results of the chemical analyses for the samples taken from the 116-H-7 borehole are presented in Table A-4, Appendix A.

3.5.2.2 Radionuclide Analysis. The results of the radionuclide analysis of soil samples taken from the 116-H-7 vadose zone borehole are presented in Table 3-10. Twelve radionuclides, consisting of Co-60, Sr-90, Cs-137, Eu-152, Eu-154, Ra-226, Th-228, Th-232, U-235, U-238, Pu-239/240, and Am-241 were detected. The majority of the radionuclide contaminants were detected within the 8.0 and $16.4 \mathrm{ft}$ interval. The complete results of the radionuclide analyses for the samples taken from borehole 116- $\mathrm{H}-7$ are presented in Table A-9, Appendix A.

3.5.2.3 Field Screening. Continuous OVM field screening of the 116-H-7 borehole for VOCs resulted in no readings above the action level of $10 \mathrm{ppm}$ above background.

Radionuclide screening showed activities ranging from 200 to $1,100 \mathrm{cpm}$ between the depths of 5.8 and $14.8 \mathrm{ft}(1.8$ and $4.5 \mathrm{~m})$. The peak of $1,100 \mathrm{cpm}$ occurred at a depth of $13.8 \mathrm{ft}$ $(4.0 \mathrm{~m})$ bgs. The radionuclide activity screening data are displayed in Figure 3-5.

3.5.2.4 Geophysical Borehole Logging. A spectral gamma-ray log was not performed on the 116-H-7 borehole because the logging equipment could not be brought into the contaminated retention basin.

\subsubsection{Conclusions}

The 116-H-7 process effluent retention basin area contains radionuclide contamination at depth and small amounts of heavy metal contamination (As and $\mathrm{Pb}$ ) near the surface. The radionuclide contamination, based on the LFI data, extends from approximately 5 to $17 \mathrm{ft}$ $(1.5$ to $5.2 \mathrm{~m})$ bgs. This is also supported by the historical data (Dorian and Richards 1978), which indicate that radionuclide contamination extended to over $20 \mathrm{ft}(6.1 \mathrm{~m})$ bgs.

Figure 3-5 presents a comparison of the various types of LFI data that were collected for the 116-H-7 retention basin and detections of contaminants from the historical data.

The 116-H-7 retention basins were considered analogous to the 116-D-7, 116-DR-9, and 116-C-5 retention basin sites. The 116-D-7, 116-DR-9, and 116-C-5 sites were sampled during the 100-DR-1 and 100-BC-1 LFls (DOE-RL 1993c and DOE-RL 1993e). To assess the concept that this site is analogous, a comparison of the radionuclide 
and chemical analytical results from the 100-DR-1 and 100-BC-1 LFI samples and the 100-HR-1 data was made. The radionuclide contaminants found beneath the 116-D-7 and 116-H-7 sites are similar; both sites contain Co-60, Sr-90, Cs-137, Eu-152, Eu-154, Ra-226, Th-228, Th-232, U-235, U-238, Pu-239/240, and Am-241. There are many radionuclide contaminants found in the 116-DR-9 site that are absent at 116-D-7 and 116-H-7. These are Be-7, Na-22, Mn-54, Co-58, Fe-59, Zn-65, Tc-99, Zn-99, Ru-103, Ru-106, Cs-134, Ba-140, Ce-141, and Ce-144. Comparisons of metallic contaminants in samples from the three sites revealed no similarities other than the presence of $\mathrm{Pb}$. The 116-D-7 site has a similar assemblage of organic contaminants to the 116-H-7 site. The 116-DR-9 site was the only site of the four that contain VOCs, SVOCs, and/or pesticides. Because the additional radionuclides at site 116-DR-9 have not been detected in 116- $\mathrm{H}-7$ samples, the 116-D-7 and 116-C-5 sites are better analogous than the 116-DR-9 site for the 116-H-7 vadose zone radionuclide contamination. This is also the case for organic contaminants and pesticides. The sites are not truly analogous.

\subsubsection{Groundwater Assessment}

Monitoring well H4-11, constructed and sampled as part of the 100-HR-3 Groundwater Operable Unit LFI (DOE-RL 1993d), is located downgradient from the 116- $\mathrm{H}-7$ retention basin and has elevated gross alpha levels $(4.3 \mathrm{pCi} / \mathrm{L})$, as well as elevated levels of Tc-99 (36 pCi $/ \mathrm{L}), \mathrm{Sr}-90(26 \mathrm{pCi} / \mathrm{L})$, and $\mathrm{Cr}(90$ micrograms $(\mu \mathrm{g}) / \mathrm{L})$ relative to upgradient wells. Monitoring well H4-13, also located downgradient of the 116-H-7 retention basin and south of $\mathrm{H} 4-11$ has elevated levels of Sr-90 only (33 pCi/L) (see Figure 3-2 for well locations). Monitoring well data suggest that the 116- $\mathrm{H}-7$ retention basin is having an impact on the groundwater, although the process effluent pipelines may also be contributing contaminants to the groundwater.

\subsection{6-H-9 REACTOR CONFINEMENT SEAL PIT DRAINAGE CRIB}

The 116-H-9 reactor confinement seal pit drainage crib is approximately 10 by 10 by $10 \mathrm{ft}$ deep ( 3 by 3 by $3 \mathrm{~m}$ ) and is located to the west of the $\mathrm{H}$ Reactor building (Figure 2-1). From 1960 to 1965 , the crib received drainage from the 132-H-2 reactor exhaust air filter building seal pits. The radioactive effluent that drained to this crib contained radionuclides with short half-lives, and the crib was released from radiological controls prior to 1967 . The crib received approximately $79,500 \mathrm{gal}(300,000 \mathrm{~L})$ of waste. Currently the site is filled with gravel and covered to grade with clean fill (WHC 1993a).

\subsubsection{Geology}

This site is characterized by sandy gravel fill to a depth of $10 \mathrm{ft}(3.0 \mathrm{~m})$ bgs. Remnants of a black plastic liner were found at a depth of $10 \mathrm{ft}(3.0 \mathrm{~m})$. Below the plastic, from 10 to $18.5 \mathrm{ft}$ ( 3.0 to $5.6 \mathrm{~m}$ ) bgs, is quarried, crushed basalt fill ranging from 1 to 4 
inches $(2.5$ to $10 \mathrm{~cm})$ in diameter. Sandy gravel material is present from 18.5 to $24.2 \mathrm{ft}(5.6$ to $7.4 \mathrm{~m}$ ) bgs, the total depth of the borehole.

\subsubsection{Soil Samples}

3.6.2.1 Chemical Analysis. The laboratory analysis results from samples taken from the 116-H-9 vadose zone borehole did not indicate any inorganic levels above the $95 \%$ UTL. (The analysis for one sample shows unrealistic levels of inorganic contaminants and was found to be in error. The inorganic data for this sample - B05WN8 - are not used for the evaluation of this site. See Table A-5 for further explanation.) There were no VOC, SVOC, or pesticide contaminants detected. The complete results of the chemical analyses for the samples taken from borehole 116- $\mathrm{H}-9$ are presented in Table A-5, Appendix A.

3.6.2.2 Radionuclide Analysis. Six radionuclides were detected at levels $<2 \mathrm{pCi} / \mathrm{g}$ (Table 3-11). The detected radionuclides consisted of Cs-137, Eu-152, Ra-226, Th-228, Th-232, and U-238. The complete results of the radionuclide analyses for the samples taken from borehole 116-H-9 are presented in Table A-10, Appendix A.

3.6.2.3 Field Screening. No VOCs were detected above the action level ( $10 \mathrm{ppm}$ above background) during continuous field screening of borehole $116-\mathrm{H}-9$, nor was radionuclide activity detected above the background level of $50 \mathrm{cpm}$.

3.6.2.4 Geophysical Borehole Logging. Logging was performed on the 116-H-9 borehole using a spectral gamma-ray system. No man-made radionuclides (Co-60, Cs-137, Eu-152, and $\mathrm{Eu}-154)$ were detected in the borehole.

\subsubsection{Conclusions}

The 116-H-9 reactor confinement seal pit drainage crib was found to have no levels of inorganic, organic, or pesticide contamination based on review of the LFI data. Radionuclides were detected in small amounts generally at a depth of 17.6 to $20.1 \mathrm{ft}$ bgs. The LFI data are supported by the historical data (Dorian and Richards 1978), which indicate a clean site. Figure 3-6 provides the geologic log and the depth of the LFI samples.

The results of the LFI on the analogous 116-D-9 crib (DOE-RL 1993c) support the non-radionuclide LFI data presented above. The radionuclides detected at the 116-D-9 site were $\mathrm{Sr}-90, \mathrm{Ra}-226$, Th-228, U-238, and Am-241 with the maximum concentration being that $\mathrm{Sr}-90$ at $2.9 \mathrm{pCi} / \mathrm{g}$. The suite of radionuclides detected at the two sites are similar but not an exact match. 
DOE/RL-93-51, Rev. 0

\subsubsection{Groundwater Assessment}

Results from sampling at monitoring well $\mathrm{H} 4-49$, located down gradient from the 116-H-9 site (see Figure 3-2 for well location), did not indicate any contamination. The 116-H-9 site does not appear to be having an impact to the groundwater.

\subsection{NON-INTRUSIVE INVESTIGATION OF OTHER HIGH-PRIORITY SITES}

\subsubsection{6-H-5 Process Effluent Outfall Structure}

The 116-H-5 outfall structure was a compartmented concrete box that overflowed to the Columbia River via a concrete sluiceway. The 116-H-5 structure measures $378 \mathrm{ft}$ long by $27 \mathrm{ft}$ wide by $14 \mathrm{ft}$ deep ( $115 \mathrm{~m}$ long by $8 \mathrm{~m}$ wide by $4 \mathrm{~m}$ deep) and is located directly to the north of the 116-H-7 retention basin. From 1949 to 1965, the outfall structure received treated process effluent from the 116-H-7 retention basin, directing it to the Columbia River through either dual 60 inch $(152 \mathrm{~cm})$ steel discharge pipes or a basalt-covered spillway down the river bank. The spillway was apparently used during periods when pipelines were unable to accommodate the effluent volume (Dorian and Richards 1978). The 116-H-5 outfall structure is now demolished and backfilled with $10 \mathrm{ft}(3 \mathrm{~m})$ of soil, except for the spillway. Waste inventories or sample analyses have not been conducted for the 116-H-5 outfall structure.

3.7.1.1 LFI Data and Analogous Sites. No LFI data have been collected for this waste site. The facilities associated with the 116-H-7 process effluent retention basin are proposed for remediation using the LFI results from the retention basin to make the decisions along the IRM path (DOE-RL 1992a). As reported in Section 3.5, the major contaminants found associated with the 116- $\mathrm{H}-7$ retention basin were radionuclides consisting of $\mathrm{Co}-60, \mathrm{Sr}-90$, Cs-137, Eu-152, Eu-154, and small amounts of Pu-239/240.

Analogous LFI data were collected from the 116-D-5 outfall structure located in the 100 D Area (DOE-RL 1993c). Table 3-12 presents the analytes from this analogous site, which may be considered COPC. The LFI data from the 116-D-5 outfall structure showed no levels of radionuclides above what could be considered typical concentrations. Radium-226 and Th-228 were detected at levels of $<1 \mathrm{pCi} / \mathrm{g}$ and are likely naturally occurring radionuclides in the soil.

3.7.1.2 Historical Data. No other data or historical information have been identified for the 116-H-5 outfall structure.

3.7.1.3 Conclusions. Because there is little information for these process outfall structures, the identification of potential contaminants is limited to information from the analogous 116-D-5 outfall structure. The data from the $116-\mathrm{H}-7$ process effluent retention basin are not likely to be representative of the 116-H-5 outfall structure site. Further analysis of the 116-H-5 outfall structure may be required in order to make an accurate assessment of the 
level and type of contamination at the site. Based solely on the analogous 116-D-5 data, little to no contamination would be expected at the 116-H-5 outfall structure.

3.7.1.4 Groundwater Assessment. Data from monitoring well $\mathrm{H} 4-4$, located immediately upgradient of the 116-H-5 outfall structure (see Figure 3-2 for well location), indicate high concentrations of gross alpha $(66 \mathrm{pCi} / \mathrm{L})$ and $\mathrm{Tc}-99(793 \mathrm{pCi} / \mathrm{L})$. The monitoring well data indicate that there is a current impact to the groundwater. However, due to the fact the well is upgradient of the 116-H-5 site, the process effluent pipelines or the 116-H-6 solar evaporation basins (WHC 1988) are more likely to be contributing contaminants.

\subsubsection{Process Effluent Pipelines}

Process effluent pipelines emanate from the $\mathrm{H}$ Reactor building to various process effluent disposal and treatment facilities. Process effluent pipelines also run from the 116-H-7 retention basin to both the Columbia River and the 116- $\mathrm{H}-1$ trench. The lines are approximately $2,000 \mathrm{ft}(610 \mathrm{~m})$ long, constructed of steel pipe, and are buried approximately $20 \mathrm{ft}(6 \mathrm{~m}) \mathrm{bgs}$. They are presumably still in place. Portions of this pipeline system lie beneath areas surrounded by security fences.

3.7.2.1 LFI Data and Analogous Sites. No LFI sampling was performed at this site. The facilities associated with the 116-H-7 process effluent retention basin are proposed for remediation using the LFI results from the retention basin to make the decisions along the IRM path (DOE-RL 1992a). As reported in Section 3.5, the major contaminants found associated with the 116- $\mathrm{H}-7$ retention basin were radionuclides consisting of $\mathrm{Co}-60, \mathrm{Sr}-90$, Cs-137, Eu-152, Eu-154, and small amounts of Pu-239/240.

One of the process effluent lines located upstream of the 116- $\mathrm{H}-7$ retention basin was investigated in 1991 (WHC 1991d) with a video camera and radiation monitor mounted on a remote-controlled crawler. No discernable breeches of the pipe integrity were observed, and the pipe was found to be sealed with concrete near the 116-H-7 retention basin. Gamma radiation levels were monitored and found to be $<1$ millirem. Smearable contamination levels were obtained from the crawler and control cable, giving a good indication of the contamination levels of the rust scale in the pipe. These levels averaged 100 to $1,000 \mathrm{cpm}$. No analogous sites were sampled.

3.7.2.2 Historical Data. Dorian and Richards (1978) indicated that soil contamination from effluent pipeline leakage in the 116- $\mathrm{H}-7$ area appears to be minimal. No measurable contamination was detected with a Geiger-Muller probe in the soil adjacent to the 116-H-7 effluent lines and junction boxes.

Limited radiological sampling was performed on the pipelines by Dorian and Richards (1978). Two sets of historical data are presented in the 100-HR-1 QRA (WHC 1993a): the maximum concentrations of radionuclides in the soil column along the effluent pipelines, and the maximum concentrations of either the sludge from 116- $\mathrm{H}-7$ retention basin or the sludge from inside the pipeline distribution box. These data show high concentrations (up to 
$26,100 \mathrm{pCi} / \mathrm{g}$ of Eu-152 when corrected for decay to 1992) in the sludge and scale samples taken from the effluent pipeline.

3.7.2.3 Conclusions. Both remote monitoring and historical data of the process effluent pipelines indicate elevated levels of radionuclide contamination. The contamination appears to be concentrated in the sludge and scale found on the inside walls of the pipe and at distribution boxes, based on the results of the historical sampling by Dorian and Richards (1978). The integrity of the section of pipeline inspected by remote sensors appeared to be adequate. The integrity of the other sections of pipeline within the 100-HR-1 Source Operable Unit is unknown. There are no known reasons to suspect that the investigated section of pipeline is not representative of the rest of the pipelines in the operable unit.

3.7.2.4 Groundwater Assessment. Because of the great linear extent of the process effluent pipelines across the 100-HR-1 Operable Unit, it is difficult to assess, from the existing monitoring wells, the current impact to groundwater posed by the process effluent pipelines. Because of the large volumes of effluent transported by the pipelines and their history of extensive leakage they are considered to be current sources of groundwater impact.

\subsubsection{6-H-7 Sludge Burial Trench}

The 116-H-7 (107-H) sludge burial trench is located to the east of the 116- $\mathrm{H}-7$ retention basin, along the Columbia River in the southeast corner of the 100-HR-1 Source Operable Unit. (There are no available data that indicate the dimensions of the trench.) The trench is not enclosed by the H Reactor security fence. Sludge from the 116-H-7 retention basin was removed in 1953 and 1965 . The material removed in 1953 was placed in the 116- $\mathrm{H}-7$ sludge burial trench; the sludge removed in 1965 was deposited in the 116- $\mathrm{H}-1$ trench.

3.7.3.1 LFI Data and Analogous Sites. No LFI sampling was performed at this site. The facilities associated with the 116-H-7 process effluent retention basin are proposed for remediation, using the LFI results from the retention basin to make the decisions along the IRM path (DOE-RL 1992a). As reported in Section 3.5, the major contaminants found associated with the 116-H-7 retention basin were radionuclides consisting of $\mathrm{Co}-60, \mathrm{Sr}-90$, Cs-137, Eu-152, Eu-154, and small amounts of Pu-239/240.

The 116-H-1 process effluent burial trench is a similar site, and both trenches received sludge from the $116-\mathrm{H}-7$ retention basin. However, the $116-\mathrm{H}-1$ trench is not considered an analogous site, because in addition to sludge from the retention basin, the 116- $\mathrm{H}-1$ site also received process effluent contaminated by fuel-element ruptures.

3.7.3.2 Historical Data. Analysis of a borehole sample taken at a depth of $15 \mathrm{ft}(4.6 \mathrm{~m})$ (Dorian and Richards 1978) detected no significant radioactive contamination. Chemical analysis was not performed. Radiological analysis identified very small amounts $(<0.5 \mathrm{pCi} / \mathrm{g})$ of Sr-90, Eu-154, and Eu-155. Carbon-14, Co-60, Cs-134, Cs-137, Eu-152, 
DOE/RL-93-51, Rev. 0

$\mathrm{Pu}-238$, and $\mathrm{Pu}-239 / 240$ were analyzed for but not detected. The 116-H-7 trench was removed from radiological controls in 1965.

No historic data have been found for organic or inorganic contaminants.

3.7.3.3 Conclusions. Based on the historical data presented in Section 3.7.3.2, the LFI data for the 116- $\mathrm{H}-7$ retention basin and the 116-H-1 effluent disposal trench may not be accurate analogous sites to the 116- $\mathrm{H}-7$ sludge burial trench with regard to radionuclide contamination levels. The historical data indicate that the $116-\mathrm{H}-7$ trench contains only very small amounts of radionuclide contamination. The levels of organic and inorganic contaminants are unknown.

There are no facilities in the 100 Area which have been or are being currently investigated as part of an LFI which are directly analogous to the 116-H-7 sludge burial trench.

3.7.3.4 Groundwater Assessment. As with the 116-H-7 retention basin, monitoring well H4-11, which was constructed and sampled as part of the 100-HR-3 Groundwater Operable Unit LFI (DOE-RL 1993d), is located downgradient from the 116-H-7 sludge burial trench and has elevated gross alpha levels $(4.3 \mathrm{pCi} / \mathrm{L})$, as well as elevated levels of $\mathrm{Tc}-99$ (36 pCi/L), Sr-90 (26 pCi/L), and $\mathrm{Cr}(90 \mu \mathrm{g} / \mathrm{L})$ relative to upgradient wells (see Figure 3-2 for well locations). Monitoring well $\mathrm{H} 4-13$, also located downgradient of the 116- $\mathrm{H}-7$ sludge burial trench and south of H4-11, has elevated levels of Sr-90 only (33 pCi/L). Monitoring well data indicate that there is a current impact to the groundwater though the $116-\mathrm{H}-7$ retention basin and the process effluent pipelines may also be contributing contaminants.

\subsubsection{2-H-3 Effluent Pumping Station}

The 132-H-3 effluent pumping station is located in the southwest corner of the 100-HR-1 Source Operable Unit, within the H Reactor building security fence, near the western edge of the $\mathrm{H}$ Reactor building. The 132-H-3 effluent pumping station consisted of four sumps containing approximately $80,000 \mathrm{gal}(302,880 \mathrm{~L})$ of water. At the time of de-commissioning in 1977 , the basins also contained approximately 1,000 gal $(3,786 \mathrm{~L})$ of sludge. This station collected and pumped water from the $\mathrm{H}$ Reactor building drains, including the irradiated fuel storage drains, into the process effluent system to the 116- $\mathrm{H}-7$ retention basin. The facility was in service from 1949 to 1965 . In 1977 sump water was removed and trucked to the $1325-\mathrm{N}$ liquid waste disposal unit in the $100-\mathrm{N}$ Area. The sludge was packaged in drums and placed in the $\mathrm{H}$ Reactor building for storage, and the 132-H-3 effluent pumping station was demolished in situ and backfilled with approximately $15 \mathrm{ft}(5 \mathrm{~m})$ of clean fill (WHC 1993a).

3.7.4.1 LFI Data and Analogous Sites. No LFI data for the 132-H-3 effluent pumping station were collected. Data collected from the analogous 132-D-3 effluent pumping station within the 110-DR-1 Source Operable Unit show no organic or inorganic contaminants and only one radionuclide ( $\mathrm{Ra}-226$ value of $<1 \mathrm{pCi} / \mathrm{g}$ at a depth of $19.8 \mathrm{ft}[6.0 \mathrm{~m}]$ ). 
3.7.4.2 Historical Data. Sludge and water samples from four sumps in the $132-\mathrm{H}-3$ effluent pumping station were analyzed before the pumping station was decommissioned. Radionuclide concentrations from these samples ranged from $3.8 \mathrm{pCi} / \mathrm{g}$ for $\mathrm{Pu}-239 / 240$ to $150 \mathrm{pCi} / \mathrm{g}$ for Co-60 and Cs-137. Radionuclides detected included $\mathrm{H}-3, \mathrm{C}-14, \mathrm{Co}-60, \mathrm{Sr}-90$, Cs-137, Eu-152, and Pu-239/240 (Dorian and Richards 1978). Radiological sampling (1977) using a Geiger-Mueller probe measured up to $4,000 \mathrm{cpm}$ of activity along the pipelines and pumps within the pumping house station.

3.7.4.3 Conclusions. The LFI data for the analogous 132-D-3 site and the historical data for the 132-H-3 site vary greatly on the type and concentration levels of radionuclide contamination to be expected in the 132-H-3 pumping station. Since the historical data were taken before the sump was drained and the sludge removed, it is probably not representative of the site's present status. The $132-\mathrm{H}-3$ site should be addressed as a solid waste burial site.

3.7.4.4 Groundwater Assessment. Due to the location of the 132-H-3 effluent pumping station relative to other closely located sites, it is impossible to accurately assess the impact of any one of these sites on the groundwater. Monitoring wells located near the $H$ Reactor building (adjacent to the 132-H-3 site) do not indicate elevated levels of contamination in the groundwater. Other sites located in the same area are the 116-H-4 pluto crib, the 116-H-9 reactor confinement seal pit drainage crib, the 116- $\mathrm{H}-2$ effluent disposal trench, 132- $\mathrm{H}-2$ exhaust air filter building, and the $132-\mathrm{H}-1$ reactor exhaust stack.

\subsubsection{2-H-2 Exhaust Air Filter Building}

The 132-H-2 (117-H) exhaust air filter building was located approximately $80 \mathrm{ft}$ $(24 \mathrm{~m})$ southwest of the $118-\mathrm{H}$ reactor building. The $132-\mathrm{H}-2$ building was a reinforced concrete structure, $59 \mathrm{ft}(18 \mathrm{~m})$ long, $39 \mathrm{ft}(12 \mathrm{~m})$ wide, and $35 \mathrm{ft}(11 \mathrm{~m})$ high, with a typical wall thickness of 15 inches $(40 \mathrm{~cm})$. Ninety percent of the structure was below the ground. It was built in 1960 to filter the $\mathrm{H}$ Reactor exhaust air before it was routed to the $132-\mathrm{H}-1$ reactor exhaust stack. The $132-\mathrm{H}-2$ building was built on the $116-\mathrm{H}-4$ pluto crib site and was subsequently demolished; the site was leveled and filled with clean soil in 1983. Contaminated rubble was buried at least $3 \mathrm{ft}(1 \mathrm{~m})$ deep, and rubble from the seal pits was buried under a minimum of $15 \mathrm{ft}(5 \mathrm{~m})$ of clean soil (WHC 1993a).

3.7.5.1 LFI Data and Analogous Sites. No LFI data have been collected at the $132-\mathrm{H}-2$ exhaust air filter building, and there are no analogous or process-related sites that have been sampled as part of an LFI. The 117-D exhaust air filter building is an analogous site that was investigated by Beckstrom and Loveland (1986) prior to the initiation of the LFI process.

3.7.5.2 Historical Data. Prior to demolition, radiation surveys and isotopic analyses of concrete and paint were made. The total estimated inventory was 0.41 millicuries of radionuclide activity including isotopes such as $\mathrm{H}-3, \mathrm{C}-14$, Co-60, Sr-90, Cs-137, Eu-152, Eu-154, and Pu-239/240 (Powers 1986). 
3.7.5.3 Conclusions. Because the site was demolished and buried in situ, it should be treated as a solid waste burial ground. Remediation of the 132-H-2 filter building will be performed during the decontamination and decommissioning of the $\mathrm{H}$ Reactor building and facilities (DOE 1989). There are no facilities in the 100 Area currently investigated as part of an LFI which are directly analogous to the $132-\mathrm{H}-2$ exhaust air filter building.

3.7.5.4 Groundwater Assessment. Due to the location of the 132-H-2 exhaust air filter building relative to other closely located sites, it is impossible to accurately assess the impact of any one of these sites on the groundwater. Monitoring wells located near the $\mathrm{H}$ Reactor building (adjacent to the 132-H-2 site) do not indicate elevated levels of contamination in the groundwater. Other sites located in the same area are the 116- $\mathrm{H}-4$ pluto crib, the $116-\mathrm{H}-9$ reactor confinement seal pit drainage crib, the 116- $\mathrm{H}-2$ effluent disposal trench, $132-\mathrm{H}-3$ effluent pumping station, and the $132-\mathrm{H}-1$ reactor exhaust stack.

\subsubsection{2-H-1 Reactor Exhaust Stack}

The 132-H-1 reactor exhaust stack was a reinforced concrete stack measuring 200 by $16 \mathrm{ft}$ ( $61 \mathrm{~m}$ by $5 \mathrm{~m}$ ), formerly located directly to the southwest of the $\mathrm{H}$ Reactor building. The stack was demolished in 1983. After the demolition of the stack, about one-third of the foundation rubble was buried in a trench located between the demolished 132-H-2 and 132-H-3 buildings. The remainder of the foundation was buried in place and covered with approximately $3 \mathrm{ft}(1 \mathrm{~m})$ of clean fill.

3.7.6.1 LFI Data and Analogous Sites. No LFI data for the $132-\mathrm{H}-1$ reactor exhaust stack have been collected, and there are no analogous sites or process-related sites that have been sampled as part of an LFI.

3.7.6.2 Historical Data. A documented release of radionuclides from the stack occurred in 1955. A ruptured fuel element burned briefly during discharge, resulting in a stack emission.

Prior to demolition of the stack, five concrete core samples were taken from the stack and analyzed for radionuclides (Beckstrom 1987). The analysis detected some levels of H-3, C-14, Co-60, Sr-90, Cs-137, and Eu-152.

3.7.6.3 Conclusions. Radionuclides were detected in the concrete samples taken from the stack when it was demolished. Available data from this site are sufficient to allow it to be addressed as a solid waste burial ground.

3.7.6.4 Groundwater Assessment. Due to the location of the $132-\mathrm{H}-1$ reactor exhaust stack relative to other closely located sites, it is impossible to accurately assess the impact of any one of these sites on the groundwater. Monitoring wells located near the $\mathrm{H}$ Reactor building (adjacent to the 132-H-1 site) do not indicate elevated levels of contamination in the groundwater. Other sites located in the same area are the 116- $\mathrm{H}-4$ pluto crib, the $116-\mathrm{H}-9$ 
reactor confinement seal pit drainage crib, the 116- $\mathrm{H}-2$ effluent disposal trench, 132-H-3 effluent pumping station, and the 132- $\mathrm{H}-2$ exhaust air filter building.

\subsubsection{6-H-4 Pluto Crib}

The 116-H-4 (105-H) pluto crib was located southwest of and adjacent to the 132-H-3 effluent pumping station. The dimensions were 4 by 4 by $2 \mathrm{ft}(1.2$ by 1.2 by $0.6 \mathrm{~m})$ deep. The 116-H-4 crib received cooling water and discharge contaminated by failed fuel elements, at a flow rate of approximately $2 \mathrm{gal} /$ minute $(7.6 \mathrm{~L} /$ minute) for short periods. This crib was in service from 1950 to 1952 . During its period of operation it was covered with $2 \mathrm{ft}$ $(0.6 \mathrm{~m})$ of soil (Stenner et al. 1988). The Waste Information Data System (WIDS) (DOE-RL $1991 \mathrm{~b})$ reported $10 \mathrm{ft}(3 \mathrm{~m})$ of soil had been used to cover the pluto crib. In 1960, the 116- $\mathrm{H}-4$ crib was excavated, and the material was buried in the 118-H-5 burial ground. Also, in 1960, the 132-H-2 (117-H) exhaust air filter building was built on the same location. After it was retired, the building was demolished and buried in situ. The filter building is discussed in Section 3.7.5.

3.7.7.1 LFI Data and Analogous Sites. No LFI data have been collected for this waste site. The 116-H-4 pluto crib was similar to the pluto cribs of the B, D, DR, and F Areas; however, the waste material has been dug up from 116-H-4 and moved to the 118-H-5 burial ground. The site is therefore not considered to be analogous to the other pluto cribs in the 100 Area. Material from the demolition of the 132-H-2 filter building is buried in place.

3.7.7.2 Historical Data. Approximately $2,200 \mathrm{lb}(1,000 \mathrm{~kg})$ of sodium dichromate were disposed of in the 116-H-4 crib. There is no radionuclide inventory of the exhumed $116-\mathrm{H}-4$ crib material.

3.7.7.3 Conclusions. The limited remains of $116-\mathrm{H}-4$ pluto crib and the $132-\mathrm{H}-2$ exhaust air filter building are viewed as a single site. The data are sufficient to indicate that the site should be addressed as a solid waste burial ground. Remediation of the site will be performed during the decontamination and decommissioning of the $\mathrm{H}$ Reactor building and facilities (DOE 1989). Materials from the 116-H-4 crib will likely be remediated in conjunction with any activity undertaken at the $118-\mathrm{H}-5$ burial ground (100-HR-2 Source Operable Unit).

3.7.6.4 Groundwater Assessment. Due to the location of the 116-H-4 pluto crib relative to other closely located sites, it is impossible to accurately assess the impact of any one of these sites on the groundwater. Monitoring wells located near the $\mathrm{H}$ Reactor building (adjacent to the 116-H-4 site) do not indicate elevated levels of contamination in the groundwater. Other sites located in the same area are the 116- $\mathrm{H}-9$ reactor confinement seal pit drainage crib, the 116- $\mathrm{H}-2$ effluent disposal trench, 132- $\mathrm{H}-3$ effluent pumping station, the 132- $\mathrm{H}-2$ exhaust air filter building, and the $132-\mathrm{H}-1$ reactor exhaust stack. 
DOE/RL-93-51, Rev. 0

\subsection{LOW-PRIORITY SITES INVESTIGATED DURING LFI}

\subsubsection{7-H-2 Septic Tank}

The 1607-H-2 septic tank served the $182-\mathrm{H}, 183-\mathrm{H}, 190-\mathrm{H}$, and several $1700-\mathrm{H}$ office and maintenance service buildings. The system, now inactive, had a 500 person capacity and three manholes available for entry. The tank is located in the northwest section of the 100-HR-1 Source Operable Unit (Figure 2-1) (DOE-RL 1992a).

3.8.1.1 Chemical Analysis of Samples. The chemical analysis of the two sludge samples and five water samples taken from the 1607-H-2 septic tank system indicated high concentrations of heavy metal and sulfate contamination (Table 3-13). The detected contaminants were predominantly confined to the sludge samples. With the exception of a small amount of methylene chloride $(300 \mu \mathrm{g} / \mathrm{L})$ detected in one water sample (Table 3-14), no VOCs were found in any of the samples. The heavy metal contaminants found included $\mathrm{Ag}, \mathrm{Ba}, \mathrm{Cd}, \mathrm{Cr}, \mathrm{Cu}, \mathrm{Hg}, \mathrm{Ni}, \mathrm{Pb}$, and $\mathrm{Zn}$; all in levels 20 to 100 times the $95 \% \mathrm{UTL}$ (Table 3-13). Arsenic and Tl were also detected above the 95\% UTL. Sulfate levels were detected at approximately five times the 95\% UTL. Table B-1 of Appendix B presents the complete chemical analysis data for the 1607-H-2 septic tank samples.

3.8.1.2 Radionuclide Analysis of Samples. The radionuclide analysis of the 1607-H-2 samples showed high concentrations of many of the radionuclides analyzed. However, it should be noted that the data validation report for this analysis indicated calibration errors in the analysis equipment, prompting rejection of most of the radionuclide data. Of the radionuclide data which were not rejected, concentrations of six radionuclides, at levels $<2.1 \mathrm{pCi} / \mathrm{g}$, were detected. Table 3-15 presents these six radionuclides detected in the sludge samples, and Table B-2 of Appendix B presents the complete radionuclide analysis results.

3.8.1.3 Conclusions. The predominant non-radionuclide contaminants detected in the 1607-H-2 septic tank samples were heavy metals and sulfate in the sludge. The source of the heavy metal contamination is unclear but may be from chemicals poured down the sanitary sewer system or may simply be from the concentration of human sewage. The radionuclide contaminants detected were Co-60, Cs-137, Eu-152, Ra-226, Th-228, and Th-232. Further or reanalysis of water and sludge samples may be necessary to adequately determine the true extent, if any, of radionuclide contamination in the $1607-\mathrm{H}-2$ septic tank.

\subsubsection{7-H-4 Septic Tank}

The 1607-H-4 septic tank received sanitary sewage from the 181- $\mathrm{H}$ river pumphouse. The system, now inactive, had a six-person capacity and a removable concrete cover. The tank is located south of the river and north of the 1607-H-2 site (Figure 2-1) (DOE-RL 1992a). 
3.8.2.1 Chemical Analysis of Samples. The chemical analysis of the soil samples taken from the test pit at the 1607-H-4 septic tank indicates no contamination of the soil in the leach field. However, a sample taken from inside the septic tank discharge pipe (sample number B07211) did indicate contamination. This contamination consisted of several heavy metals $(\mathrm{Ba}, \mathrm{Cu}, \mathrm{Pb}$, and $\mathrm{Zn})$ at levels above the $95 \%$ UTL and semi-volatile PNA compounds (Tables 3-16, 3-17, and 3-18). The PNAs were detected in concentrations of $<3 \mathrm{mg} / \mathrm{kg}$. Pesticides 4,4-DDD, 4,4-DDE, and gamma-chlordane were detected at levels of $<1 \mathrm{mg} / \mathrm{kg}$ in the sample taken from the discharge pipe (Table 3-19). As discussed earlier, PNAs may be associated with coal tars or creosote (Ekambaram et al. 1988). Table B-3, Appendix B, presents the complete chemical analysis data for 1607-H-4 soil samples.

3.8.2.2 Radionuclide Analysis of Samples. The soil samples taken from the test pit and from the septic tank discharge pipe contained small amounts of Cs-137, Eu-152, Ra-226, Th-228, Th-232, U-233/234, and U-238 in concentrations $\leq 1.2 \mathrm{pCi} / \mathrm{g}$ (Table 3-20). Table B-4, Appendix B, presents the complete radionuclide analysis results for the samples taken from the 1607-H-4 septic tank excavation.

3.8.2.3 Conclusions. Heavy metals, small amounts of PNAs, and radionuclide contamination were found in a sample taken from the discharge pipe of the $1607-\mathrm{H}-4$ septic tank. No contaminants were detected in the soil samples taken from the test pit in the septic tank leach field. This suggests that there may be isolated areas of concentrated contaminants within the septic tank itself (which is backfilled) and in and immediately around the discharge piping, but that there is little contamination within the leach field soil itself.

\subsubsection{Electrical Facilities}

Several abandoned electrical facilities exist within the 100-HR-1 Source Operable Unit. Electrical equipment, including transformers containing PCBs, were used at some of these sites. The sampling locations are shown in Figure 2-1 (DOE-RL 1992a).

3.8.3.1 PCB Analysis of Samples. Surface soil samples were taken from the electrical facilities where PCB contamination was suspected (i.e., visible spills and areas where equipment containing PCBs was used) and analyzed for PCB contamination. Polychlorinated biphenyls were detected in five of the eight samples analyzed in levels ranging from 32 to $1,200 \mu \mathrm{j} / \mathrm{kg}$ (Table 3-21). Aroclor-1254 was detected in two of the samples taken from the $151-\mathrm{H}$ facility area, and Aroclor- 1260 was detected in two samples taken from the $151-\mathrm{H}$ facility area and also in a sample taken from outside the $105-\mathrm{H}$ building (Figure 2-1). Table B-5 in Appendix B provides the complete laboratory data results for the eight samples taken.

3.8.3.2 Conclusions. Polychlorinated biphenyls were detected in surface soil samples collected around abandoned electrical facilities in the 100-HR-1 Source Operable Unit. The physical extent of the contamination is not presently known but could likely be determined by visual inspection of the sample sites. 


\subsubsection{Support Facilities}

The 100-HR-1 radiological survey field task consisted of two activities: characterization of the operable unit-specific background conditions and the radiological survey of the operable unit surface area. The purpose of the radiological survey was to measure gross gamma radiation levels of the surface soil.

The total surface area surveyed was approximately 105 acres. Within this area, a total of 126,425 data points were collected. Each of these data points represents a gross gamma radiation reading, along with the physical coordinates of the reading location. A total of 127 individual surveys were conducted in order to complete the 105 acres of surface area. Sections of the operable unit not surveyed include the area inside the 116-H-7 exclusion fence, the 116-H-6 solar basin, and the river shore.

During the period of time when the 100-HR-1 radiation survey was conducted, the Columbia River was relatively high; therefore, the portion of the 100-HR-1 Source Operable Unit below the riverbank crest could not be effectively surveyed.

Of the 127 surveys conducted at the 100-HR-1 site, 22 surveys recorded elevated readings. However, in only 10 of the 22 surveys could the elevated readings be verified and duplicated. The elevated readings in the remaining 12 surveys are interpreted to have been caused by noise spikes introduced by loose or faulty cables connecting the gamma detector to the digital rate meter. Any faulty cables were repaired or replaced. Figure 3-7 shows the ten locations where contamination was detected. Details on the radiological survey and the complete results are found in 100-HR-1 Radiological Surveys (Beckstrom and Wade 1991).

\subsection{APPLICABLE OR RELEVANT AND APPROPRIATE REQUIREMENTS}

Section 121(d) of CERCLA, as amended by the Superfund Amendments and Reauthorization Act of 1986, requires that fund-financed, enforcement, and federal facility remedial actions comply with ARARs of federal environmental laws and more stringent, promulgated state environmental or facility siting laws.

Comprehensive Environmental Response Compensation and Liability Act defines applicable requirements as those cleanup standards, standards of control, and other substantive environmental protection requirements, criteria, or limitations promulgated under federal or state law that specifically address a hazardous substance, pollutant, contaminant, remedial action, location, or other circumstance at a CERCLA site. Relevant and appropriate requirements are those cleanup standards, standards of control, and other substantive environmental protection requirements, criteria, or limitations promulgated under federal or state law that, while not "applicable" to a hazardous substance, pollutant, contaminant, remedial action, location, or other circumstance at a CERCLA site, address problems or situations sufficiently similar to those encountered at the CERCLA site that their use is well suited to the particular site. 
In addition to ARARs, CERCLA also provides for the consideration of to-be-considered (TBC) guidance, non-promulgated advisories or guidance documents issued by federal or state governments that do not have the status of potential ARARs but which may be considered in determining necessary levels of protection of health or the environment.

Applicable or relevant and appropriate requirements may be further subdivided into the following categories:

- Chemical-specific requirements-health- or risk-based numerical values or methodologies that, when applied to site-specific conditions, result in the establishment of numerical values. If a chemical has more than one such requirement that is an ARAR, compliance should generally be with the most stringent requirement.

- Location-specific requirements-restrictions placed on the concentration of hazardous substances or the conduct of activities solely because they are in specific locations, such as wetlands or historic places.

- Action-specific requirements-technology- or activity-based requirements or limitations on actions taken with respect to hazardous wastes. These requirements are triggered by the particular remedial activities that are selected to accomplish a remedy.

Potential chemical- and location-specific ARARs are defined during the field investigation portion of the CERCLA process and refined in the feasibility study and proposed plan. Action-specific ARARs are generally defined during the phase I and II feasibility study and refined in detailed analysis and the proposed plan. Potential ARARs and TBCs in all categories are defined in the 100 Area Feasibility Study Phases 1 and 2 (DOE-RL 1992c). For purposes of this LFI, only the chemical- and location-specific ARARs are discussed. Chemical- and location-specific ARARs are used in the LFI report as screening criteria for the evaluation of high-priority sites as IRM candidates. This use of ARARs is not intended to set cleanup standards for the high-priority sites. Chemical-and location-specific ARARs are presented in Tables 3-22 through 3-27.

Chemical-specific ARARs for soils are limited to those levels for hazardous constituents prescribed in the state's MTCA. Currently, MTCA has not defined levels for radionuclides. Additional soil limits are presented in Subpart S of RCRA for hazardous constituents and in DOE Order 5400.5 for radionuclides. These are considered TBCs for the 100 Area operable units. Potential chemical-specific ARARs for air emissions are also identified for the 100 Area; however, these tend to also be based on specific actions which have a tendency to increase releases to the air. Therefore, these are more appropriately addressed in the focused feasibility study. Potential chemical-specific ARARs are listed in Table 3-22 and 3-23; TBCs are included in Table 3-24. 
Potential location-specific ARARs are identified for the 100 Area because of the presence of threatened or endangered species and archaeological resources. In addition, potential location-specific ARARs based on possible impacts to wetlands and floodplains are included. These are described in Tables 3-25 and 3-26; TBCs are in Table 3-27.

This discussion of potential ARARs is intended to be a refinement of ARARs presented in the work plan. Additional evaluation of potential ARARs will be done in the FS phase. Final ARARs will be determined in the ROD. 


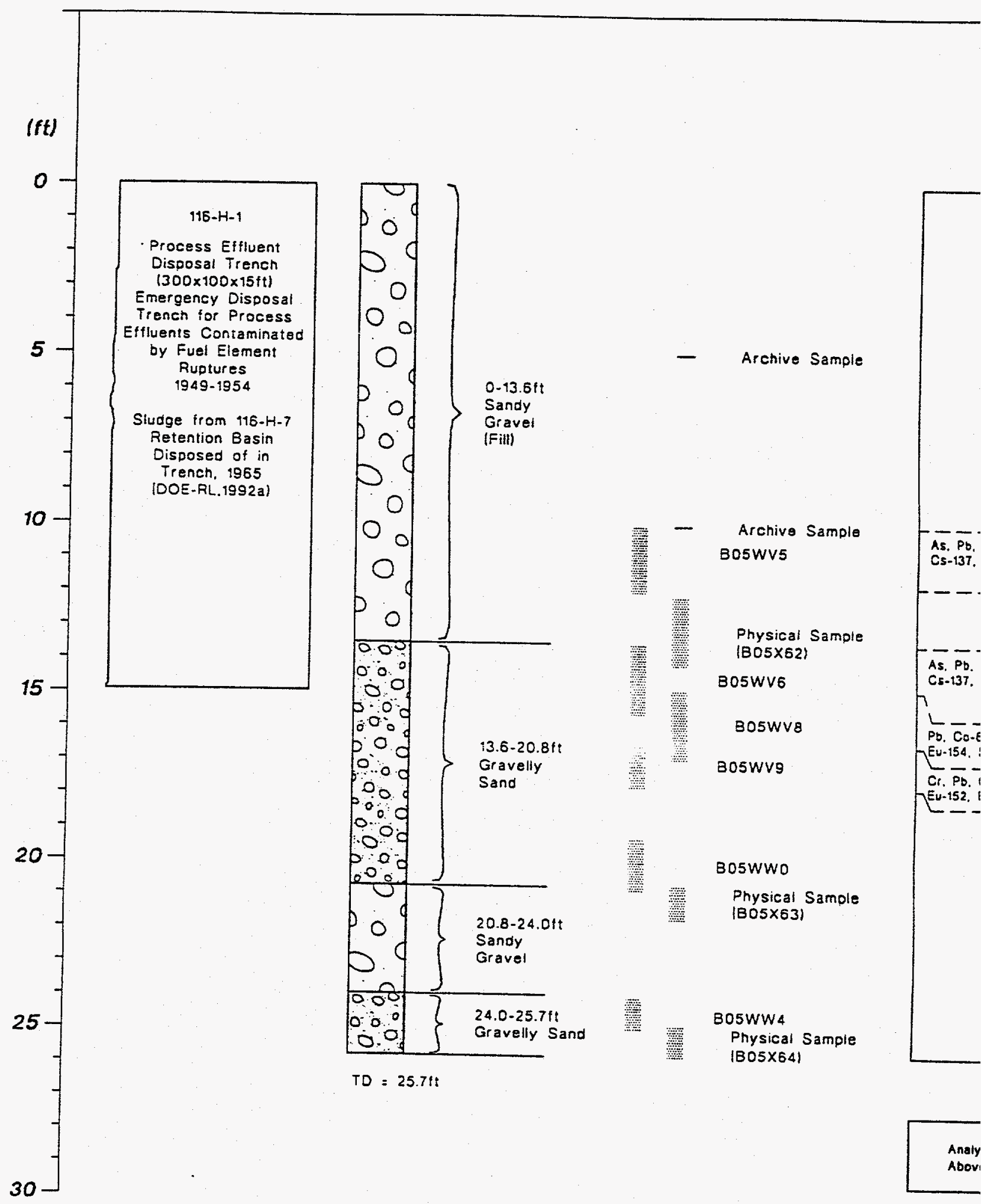


DOE/RL-93-51, Rev. 0

Figure 3-1 Sampling Results for 116-H-1 Process Effluent Disposal Trench

Spectral Gamma- Darian and Richards

Ray Logging

Depth Activity
(II)
(CPM)

26. Co.60

52. Ev-t54

$---1$

s. $\overline{c 0.50}--$

52. Eu-154

$-----$

is-137. Eu-152.

iD. $\overline{\mathrm{C}}-\frac{}{\mathrm{C} \cdot 137}$

i. $5 r-90$, Th -90

- -1 -
Co-60 Cs-137 Eu-\{52 Eu-154

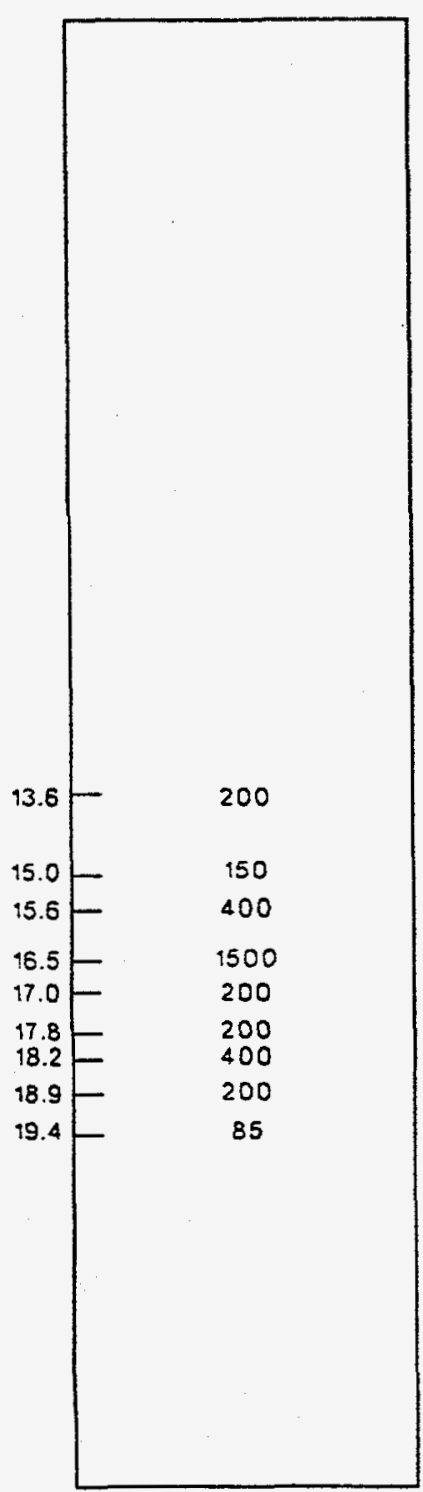

Action Levels



Maximum Survey Depth

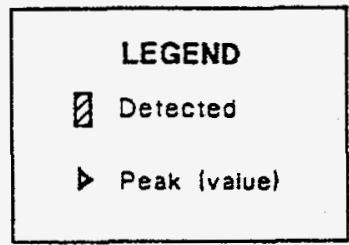

Pu-238. Pu-239/240 Sr-90, Eu-152, EU-154, Co.60. Cs-137. Eu-155

Pu-239/240. Sr -90 ,

Eu-152, Eu-154, Co.60.

Cs-137. EU-155

Pu-239/240. Sr-90.

Eu-152. Eu-154, Co.60.

Cs-137, Eu-155

Sr-90, Eu-152, EU-154.

Co-60. Cs-137. Eu-155

$-10$

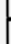

$-15$

$-$

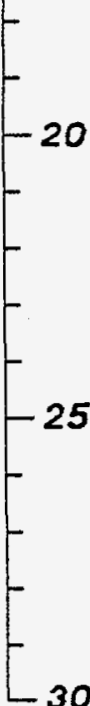


DOE/RL-93-51, Rev. 0

Figure 3-2 Well Locations in the $100 \mathrm{H}$ Area

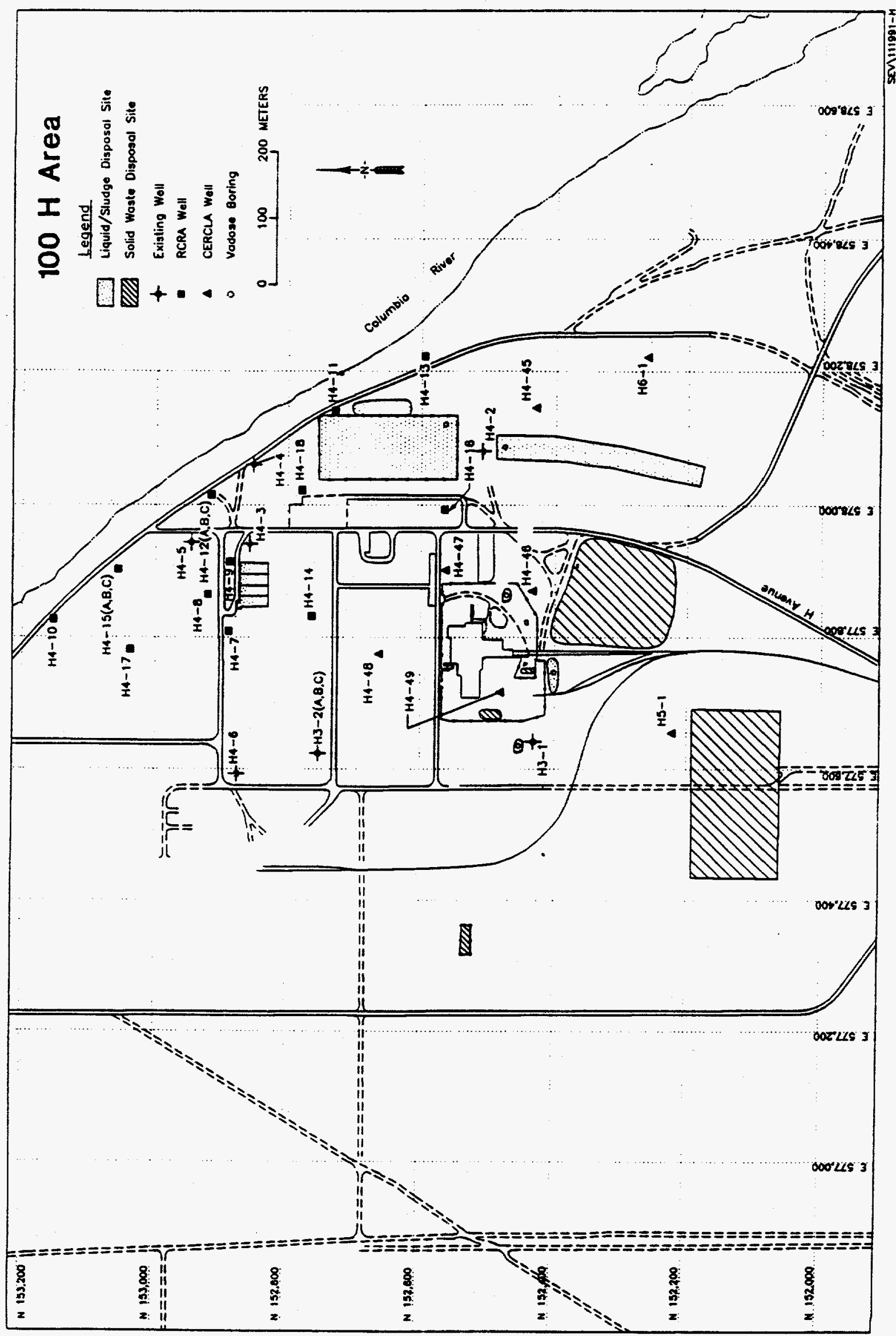




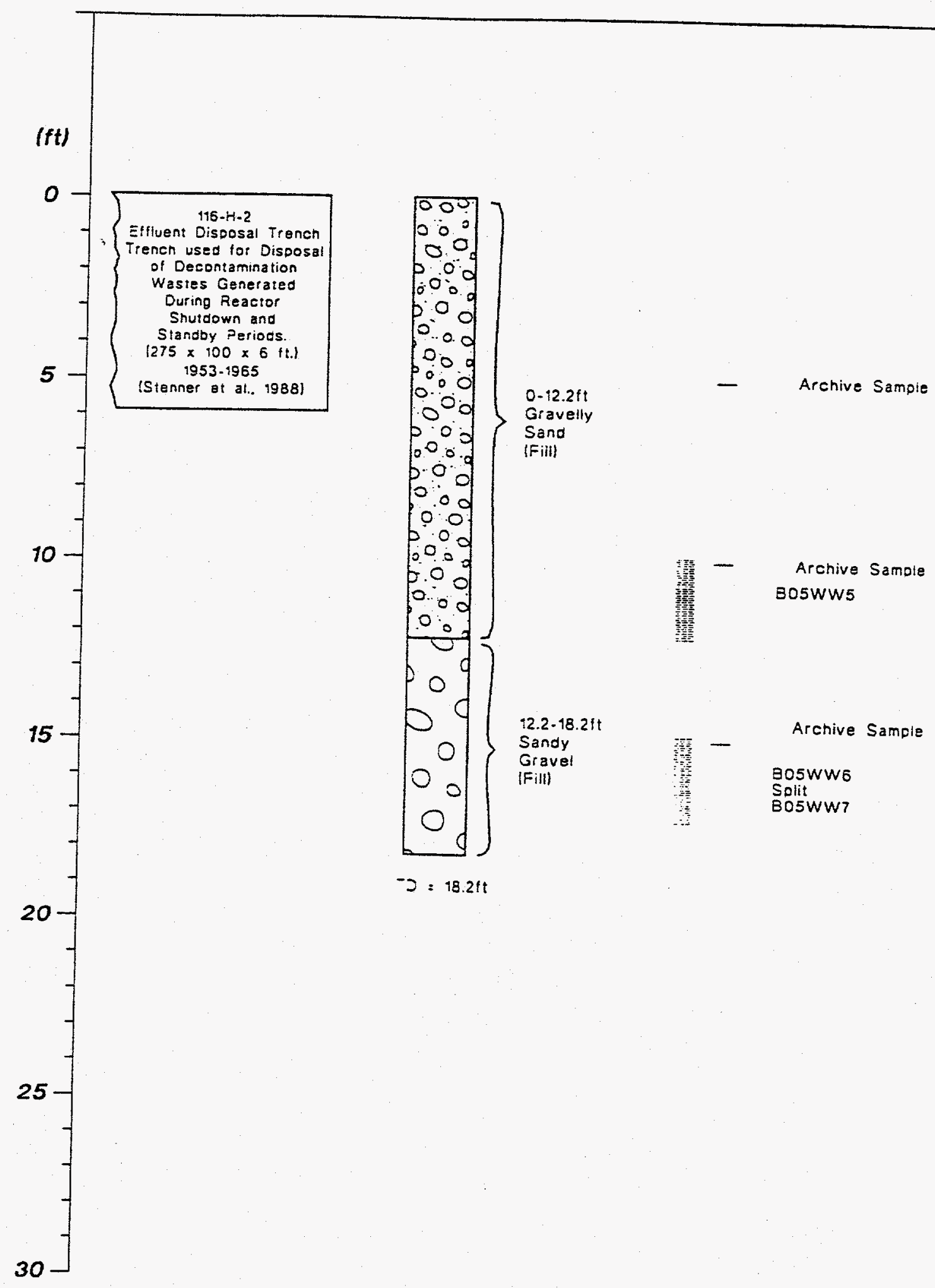


DOE/RL-93-51, Rev. 0

Figure 3-3 Sampling Results for 116-H-2 Effluent Disposal Trench

Field Screening (GM Count)
Spectral GammaRay Logging
Dorian and Richards

(1978)
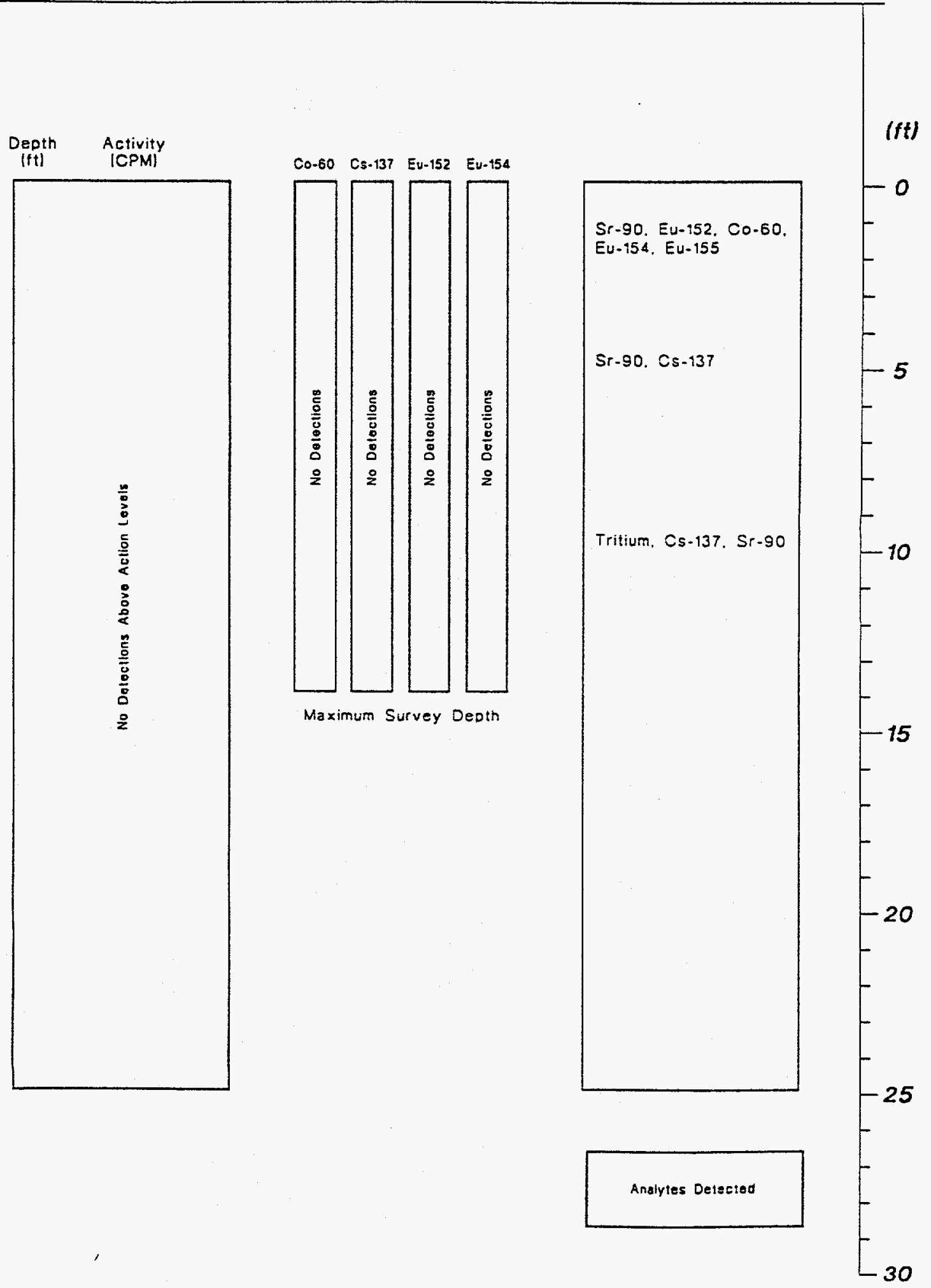


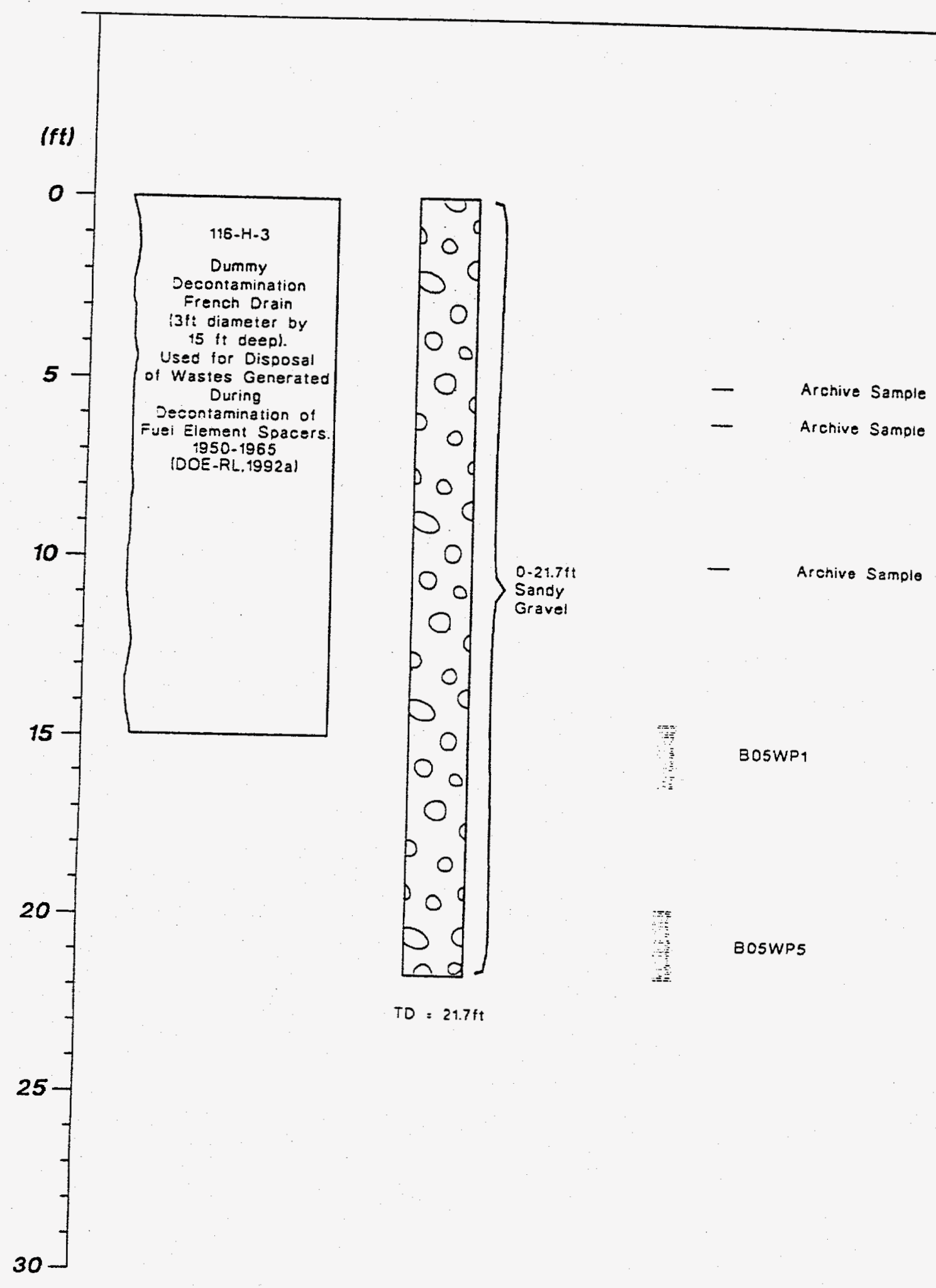




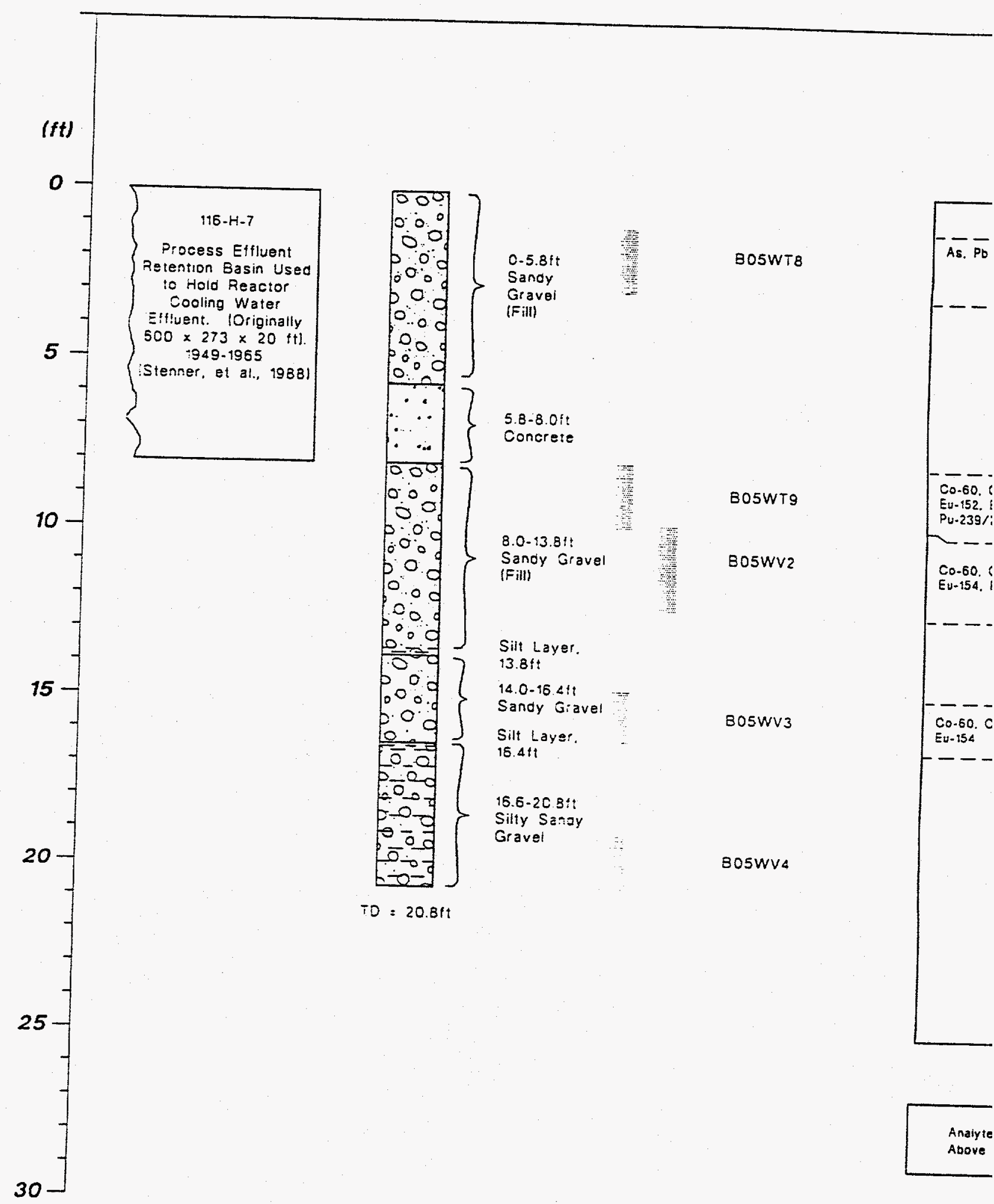




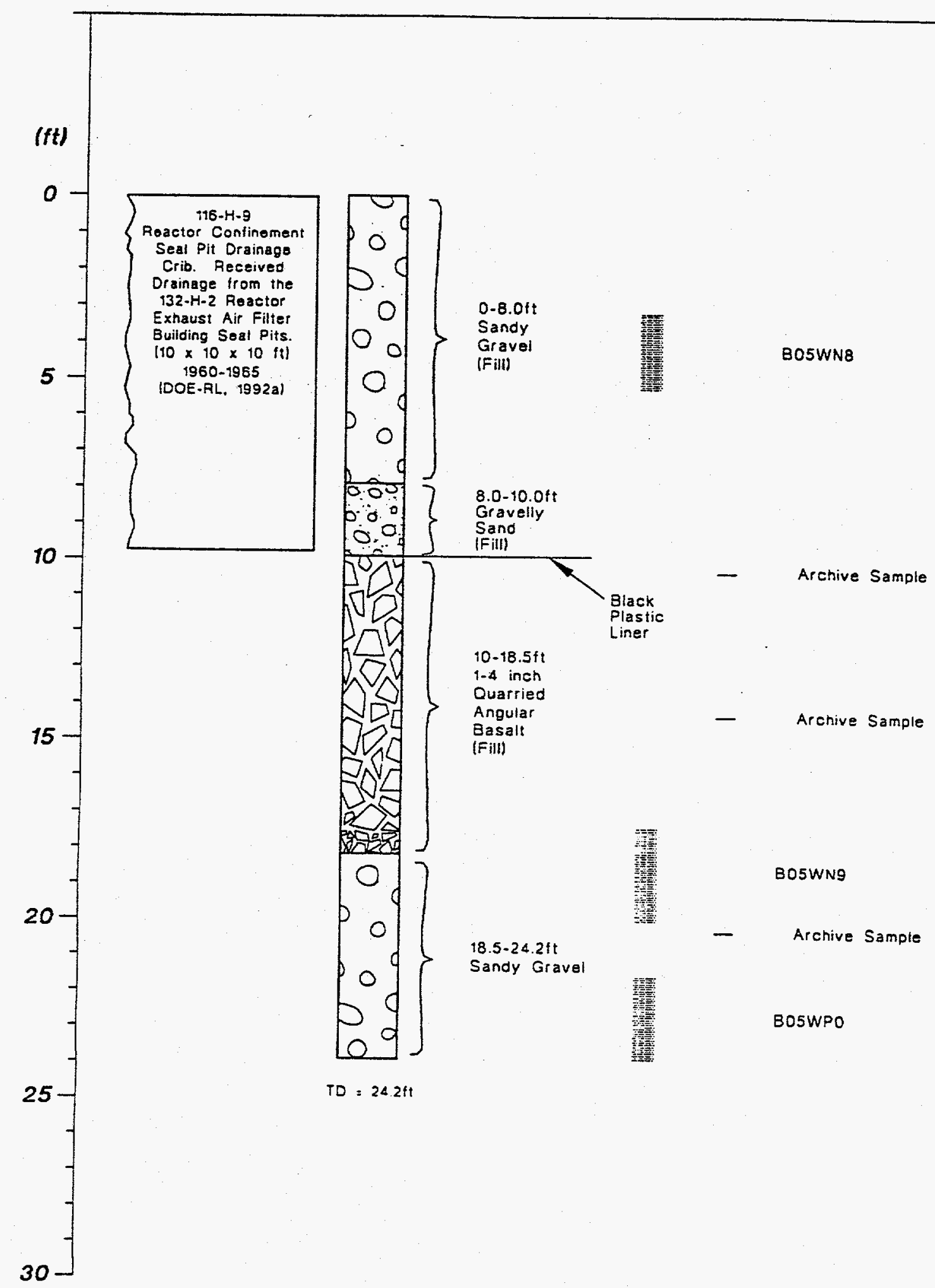


DOE/RL-93-51, Rev. 0

Figure 3-6 Sampling Results for 116-H-9 Reactor Confinement Seal Pit Drainage Crib

\begin{tabular}{|c|c|c|}
\hline & $\begin{array}{l}\text { Field Screening } \\
\text { (GM Count) }\end{array}$ & $\begin{array}{c}\text { Spectral Gamma- } \\
\text { Ray Logging }\end{array}$ \\
\hline
\end{tabular}

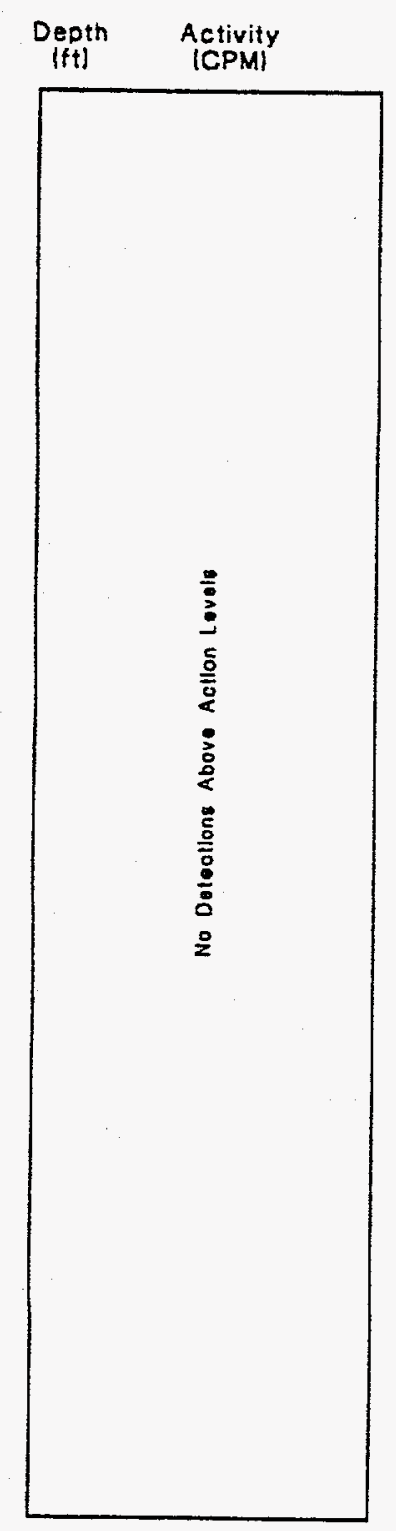

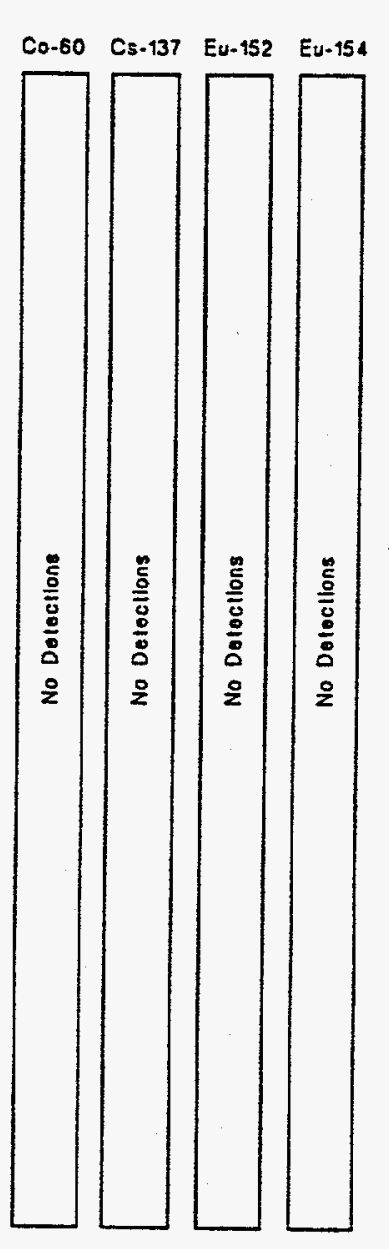

Maximum Survey Depth

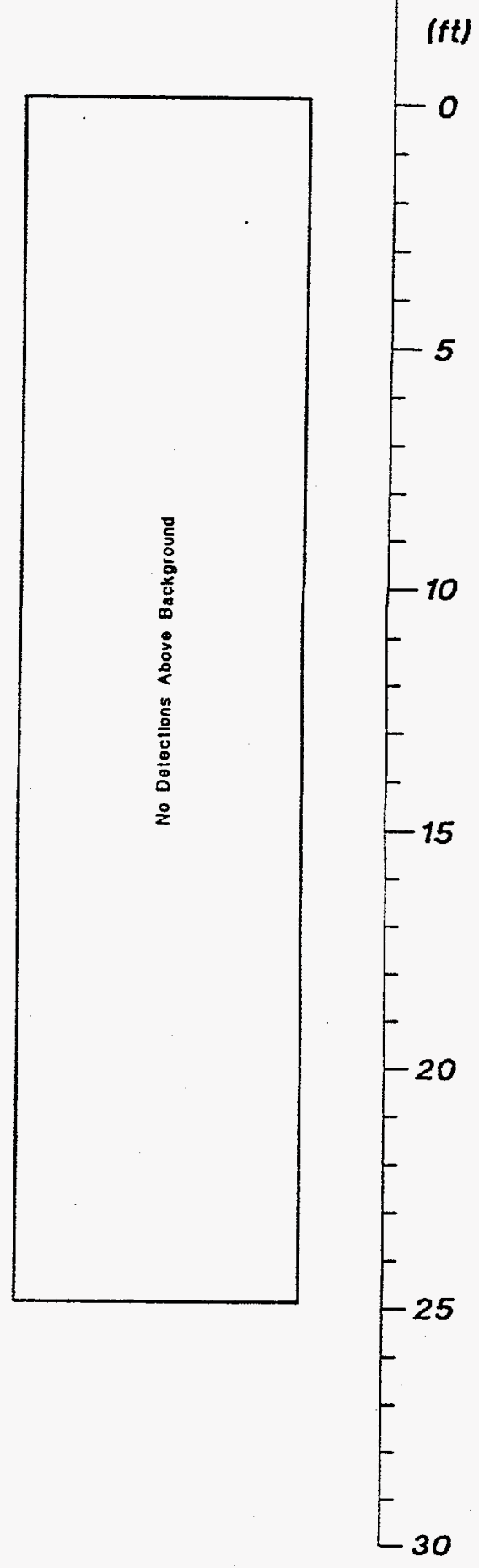




\section{Figure 3-7 100-HR-1 Surface Radiological Survey Contamination Points}

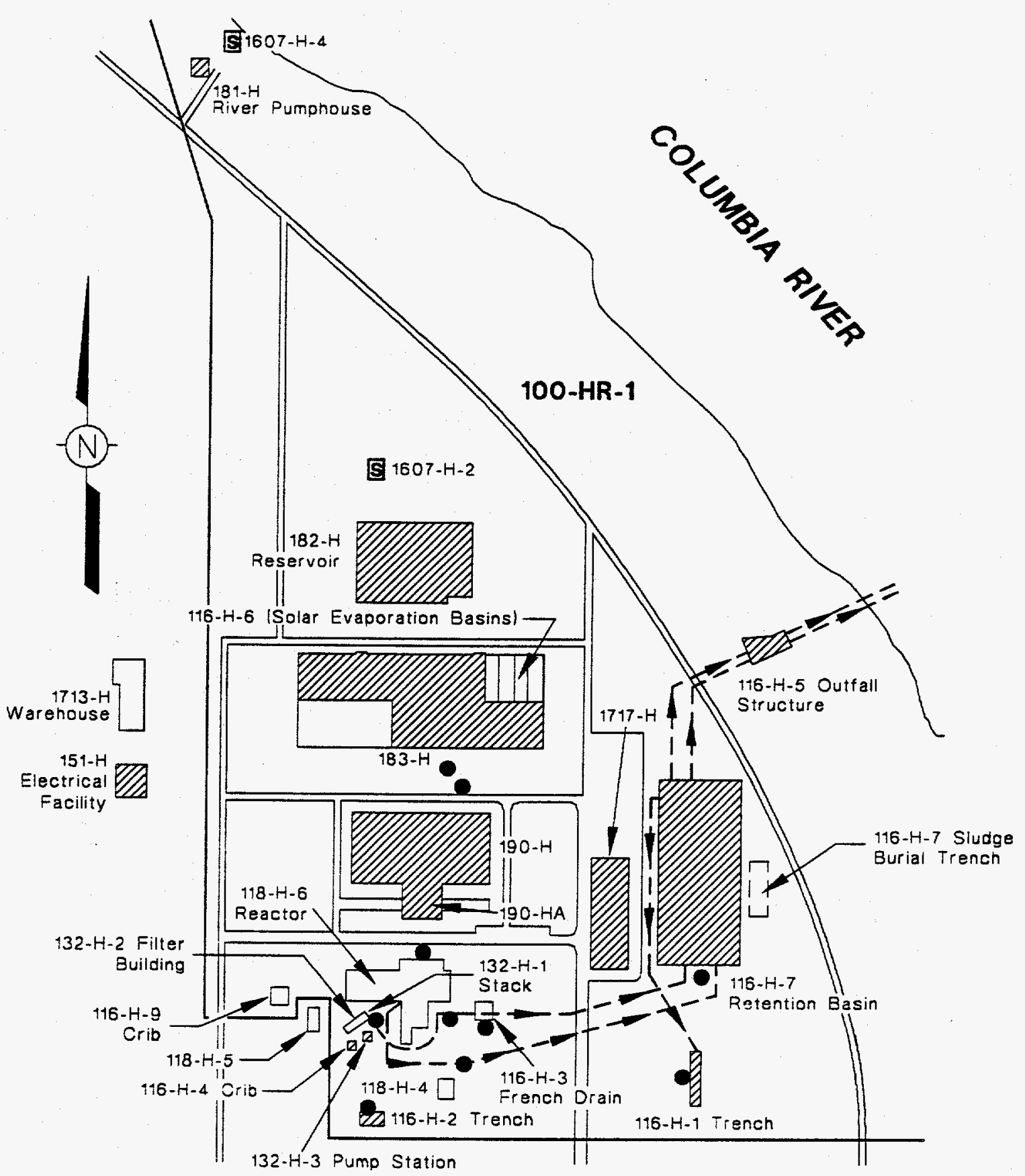

\section{LEGEND}

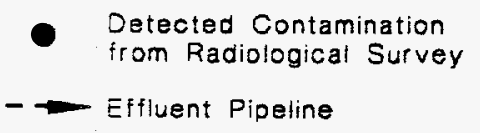

$-\rightarrow$ Effluent Pipeline 
DOE/RL-93-51, Rev. 0

Table 3-1 Summary Statistics and Upper Threshold Limits for Inorganic Analytes*

\begin{tabular}{|c|c|c|}
\hline Analyte & $\begin{array}{c}95 \% \text { Distribution } \\
\text { (mg/kg) }\end{array}$ & $\begin{array}{c}95 \% \text { UTL } \\
\text { (mg/kg) }\end{array}$ \\
\hline Aluminum & 13,800 & 15,600 \\
\hline Antimony & NR & $15.7^{c}$ \\
\hline Arsenic & 7.59 & 8.92 \\
\hline Barium & 153 & 171 \\
\hline Beryllium & 1.62 & 1.77 \\
\hline Cadmium & NR & $0.66^{\circ}$ \\
\hline Calcium & 20,410 & 23,920 \\
\hline Chromium & 23.4 & 27.9 \\
\hline Cobalt & 17.9 & 19.6 \\
\hline Copper & 25.3 & 28.2 \\
\hline Iron & 36,000 & 39,160 \\
\hline Lead & 12.46 & 14.75 \\
\hline Magnesium & 7,970 & 8,760 \\
\hline Manganese & 562 & 612 \\
\hline Mercury & 0.614 & 1.25 \\
\hline Nickel & 22.4 & 25.3 \\
\hline Potassium & 2,660 & 3,120 \\
\hline Selenium & NR & $5^{c}$ \\
\hline Silver & 1.4 & 2.7 \\
\hline Sodium & 963 & 1,290 \\
\hline Thallium & NR & $3.7^{c}$ \\
\hline Vanadium & 98.2 & 111 \\
\hline Zinc & 73.3 & 79 \\
\hline Molybdenum & NR & $1.4^{\mathrm{c}}$ \\
\hline Titanium & 3,020 & 3,570 \\
\hline Zirconium & 47.3 & 57.3 \\
\hline Lithium & 35 & 37.1 \\
\hline Ammonia & 15.3 & 28.2 \\
\hline Alkalinity & 13,400 & 23,300 \\
\hline Silicon & 108 & 192 \\
\hline Fluoride & 6.4 & 12 \\
\hline Chloride & 303 & 763 \\
\hline Nitrite & NR & $21^{\circ}$ \\
\hline Nitrate & 96.4 & 199 \\
\hline Ortho-phosphate & 3.7 & 16 \\
\hline Sulfate & 580 & 1,320 \\
\hline
\end{tabular}

"Source: DOE-RL 1993a.

NR $=$ Not reported.

95th percentile of the data for a lognormal distribution.

- 95 percent confidence limit of the 95th percentile of the data distribution.

Limit of detection. 
DOE/RL-93-51, Rev. 0

Table 3-2 Vadose Zone Borehole 116-H-1-Inorganic Analysis

\begin{tabular}{||l|c|c|c|c||}
\hline Analyte & $\begin{array}{c}\text { Sample Depth } \\
\text { (ft) }\end{array}$ & $\begin{array}{c}\text { Concentration } \\
\text { Detected } \\
\text { (mg/kg) }\end{array}$ & $\begin{array}{c}\text { Background } \\
\text { 95\% UTL } \\
\text { (mg/kg) }\end{array}$ & $\begin{array}{c}\text { Qualifiers/ } \\
\text { Comments }\end{array}$ \\
\hline \hline Arsenic & $10.0-12.0$ & 37.90 & 8.92 & \\
& $13.6-15.6$ & 27.60 & 8.92 & \\
Chromium & $16.5-17.8$ & 29.60 & 27.90 & \\
Lead & $10.0-12.0$ & 187 & 14.75 & \\
& $13.6-15.6$ & 145 & 14.75 & \\
& $15.0-17.0$ & 36.90 & 14.75 & \\
& $16.5-17.8$ & 82.10 & 14.75 & \\
\hline
\end{tabular}

This table shows only those analytes that had levels above the 95 percent UTL. 
DOE/RL-93-51, Rev. 0

Table 3-3 Vadose Zone Borehole 116-H-1-Volatile Organic Analysis

\begin{tabular}{||c|c|c|c|c||}
\hline Analyte & $\begin{array}{c}\text { Sample Depth } \\
(\mathrm{ft})\end{array}$ & $\begin{array}{c}\text { Concentration } \\
\text { Detected } \\
(\mu \mathrm{g} / \mathrm{kg})\end{array}$ & $\begin{array}{c}\text { Contract } \\
\text { Required } \\
\text { Quantitation } \\
\text { Limit } \\
(\mu \mathrm{g} / \mathrm{kg})^{\mathrm{a}}\end{array}$ & \multicolumn{1}{|c||}{$\begin{array}{c}\text { Qualifiers/ } \\
\text { Comments }\end{array}$} \\
\hline \hline Acetone & $13.6-15.6$ & 12 & 10.0 & $\begin{array}{l}\text { Split sample had no } \\
\text { detection. Analyte is a } \\
\text { typical laboratory } \\
\text { contaminant and detection } \\
\text { is probably laboratory } \\
\text { contamination. } \\
\text { Methylene } \\
\text { Chloride }\end{array}$ \\
$10.0-12.0$ & 11 & 10.0 & $\begin{array}{l}\text { Data for this sample was } \\
\text { not validated. Other } \\
\text { samples from lab had } \\
\text { methylene chloride in lab } \\
\text { blank. Detection is } \\
\text { probably laboratory } \\
\text { contamination. } \\
\text { Data for this sample not } \\
\text { validated. Analyte is a } \\
\text { typical laboratory } \\
\text { contaminant and detection } \\
\text { is probably laboratory } \\
\text { contamination. }\end{array}$ \\
\hline Toluene & $10.0-12.0$ & 14 & 10.0 \\
\hline
\end{tabular}

This table shows only those analytes that had levels above the Contract Required Quantitation Limit. ${ }^{a}$ From QAPjP (DOE-RL 1992a). 
DOE/RL-93-51, Rev. 0

Table 3-4 Vadose Zone Borehole 116-H-1-Semivolatile Organic Analysis

\begin{tabular}{|l|c|c|c|c||}
\hline \multicolumn{1}{|c|}{ Analyte } & $\begin{array}{c}\text { Sample } \\
\text { Depth } \\
\text { (ft) }\end{array}$ & $\begin{array}{c}\text { Concentration } \\
\text { Detected } \\
(\mu \mathrm{gg} / \mathrm{kg})\end{array}$ & $\begin{array}{c}\text { Contract } \\
\text { Required } \\
\text { Quantitation } \\
\text { Limit } \\
(\mu \mathrm{g} / \mathrm{kg})^{\mathrm{a}}\end{array}$ & $\begin{array}{c}\text { Qualifiers/ } \\
\text { Comments }\end{array}$ \\
\hline Anthracene & $13.6-15.6$ & 430 & 330.0 & \\
Benzo(a)anthracene & $13.6-15.6$ & 940 & 330.0 & \\
Benzo(a)pyrene & $13.6-15.6$ & 810 & 330.0 & \\
Benzo(b)fluoranthene & $13.6-15.6$ & 890 & 330.0 & \\
Benzo(ghi)perylene & $13.6-15.6$ & 410 & 330.0 & \\
Benzo(k)fluoranthene & $13.6-15.6$ & 760 & 330.0 & \\
Chrysene & $13.6-15.6$ & 920 & 330.0 & \\
Fluoranthene & $13.6-15.6$ & 1800 & 330.0 & \\
Indeno(1,2,3-cd)pyrene & $13.6-15.6$ & 520 & 330.0 & \\
Phenanthrene & $13.6-15.6$ & 1500 & 330.0 & 330.0 \\
Pyrene & $13.6-15.6$ & 1200 & \\
\hline
\end{tabular}

This table shows only those analytes that had levels above the Contract Required Quantitation Limit. ${ }^{\text {a}}$ From QAPjP (DOE-RL 1992a). 


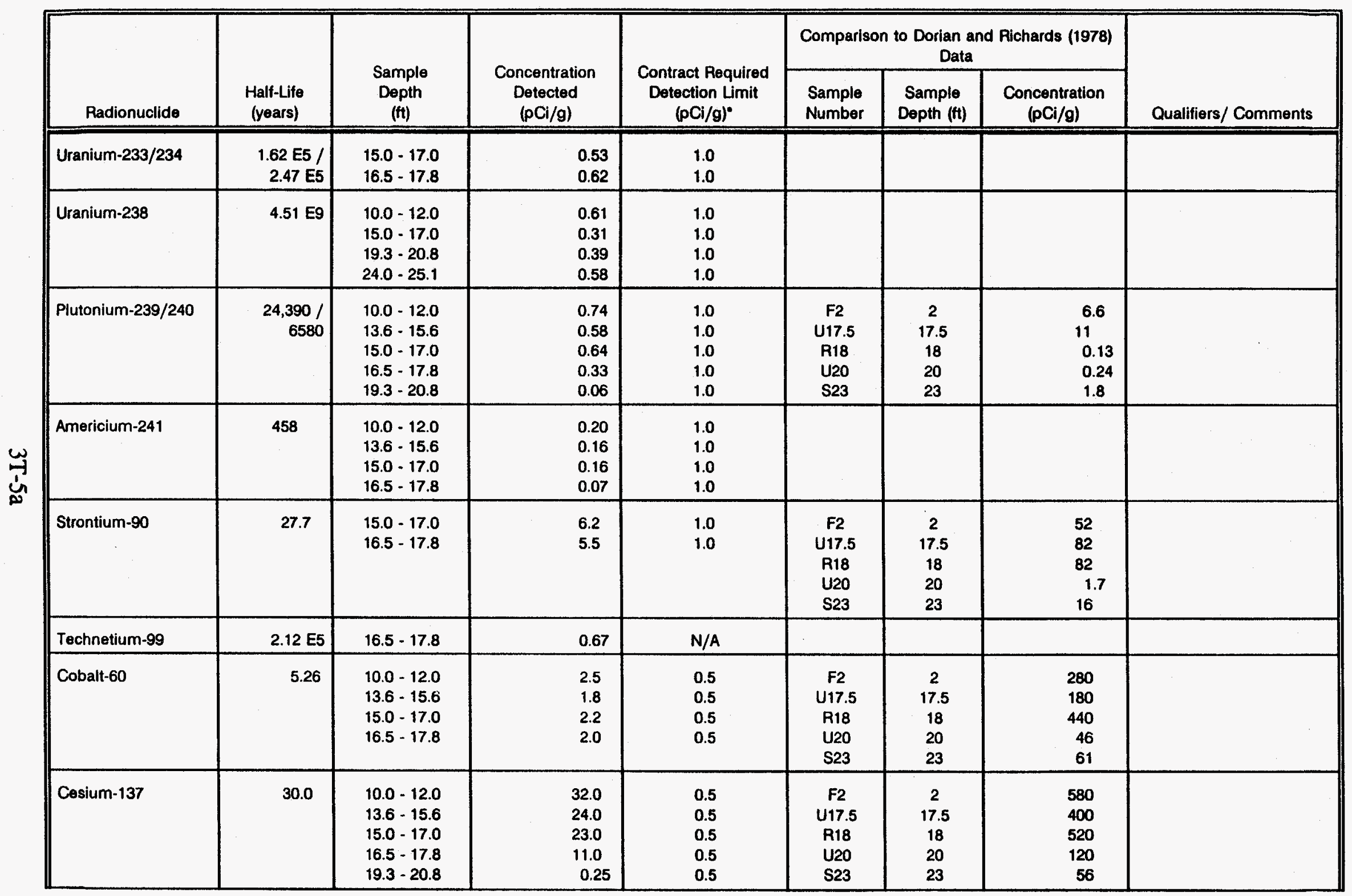




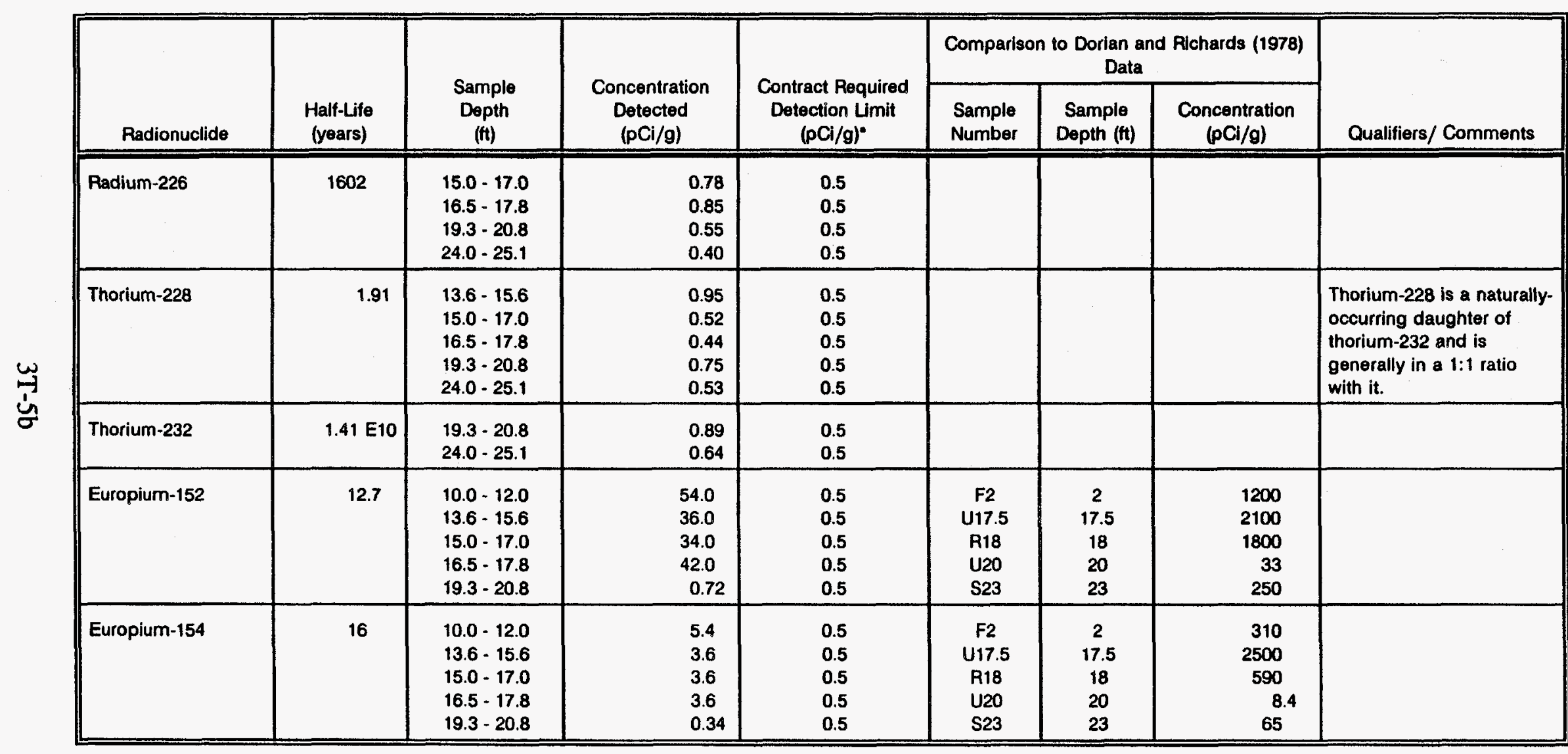

-From QAPjP (DOE-RL 1992a).

$\mathrm{N} / \mathrm{A}=$ Not Available - There is no Contract Required Detection Limit specified in the QAPjP for this radionuclide. 
DOE/RL-93-51, Rev. 0

Table 3-6 Vadose Zone Borehole 116-H-2-Radionuclide Analysis

\begin{tabular}{|c|c|c|c|c|c|}
\hline Radionuclide & $\begin{array}{c}\text { Half-Life } \\
\text { (years) }\end{array}$ & $\begin{array}{l}\text { Sample } \\
\text { Depth } \\
\text { (ft) }\end{array}$ & $\begin{array}{l}\text { Concentration } \\
\text { Detected } \\
\text { (pCi/g) }\end{array}$ & $\begin{array}{l}\text { Contract } \\
\text { Required } \\
\text { Detection Limit } \\
(\mathrm{pCi} / \mathrm{g})^{\mathrm{a}}\end{array}$ & $\begin{array}{l}\text { Qualifiers/ } \\
\text { Comments }\end{array}$ \\
\hline Uranium-238 & 4.51 E9 & $\begin{array}{c}9.9-12.1 \\
14.9-17.2\end{array}$ & $\begin{array}{l}0.33 \\
0.54\end{array}$ & $\begin{array}{l}1.0 \\
1.0\end{array}$ & \\
\hline Radium-226 & 1602 & $\begin{array}{r}9.9-12.1 \\
14.9-17.2 \\
\end{array}$ & $\begin{array}{l}0.37 \\
0.50 \\
\end{array}$ & $\begin{array}{l}0.5 \\
0.5 \\
\end{array}$ & \\
\hline Thorium-228 & 1.91 & $\begin{array}{c}9.9-12.1 \\
14.9-17.2\end{array}$ & $\begin{array}{l}0.49 \\
0.63\end{array}$ & $\begin{array}{l}0.5 \\
0.5\end{array}$ & $\begin{array}{l}\text { Thorium-228 is a } \\
\text { naturally- } \\
\text { occurring } \\
\text { daughter of } \\
\text { thorium- } 232 \text { and } \\
\text { is generally found } \\
\text { in a } 1: 1 \text { ratio with } \\
\text { it. }\end{array}$ \\
\hline Thorium-232 & $1.41 \mathrm{E} 10$ & $9.9-12.1$ & 0.35 & 0.5 & \\
\hline
\end{tabular}

There were no radionuclides detected in both LFI vadose borehole analysis data and Dorian and Richards (1978) historical data to allow a comparison.

${ }^{\text {a } F r o m ~ Q A P J P ~(D O E-R L ~ 1992 a) . ~}$ 


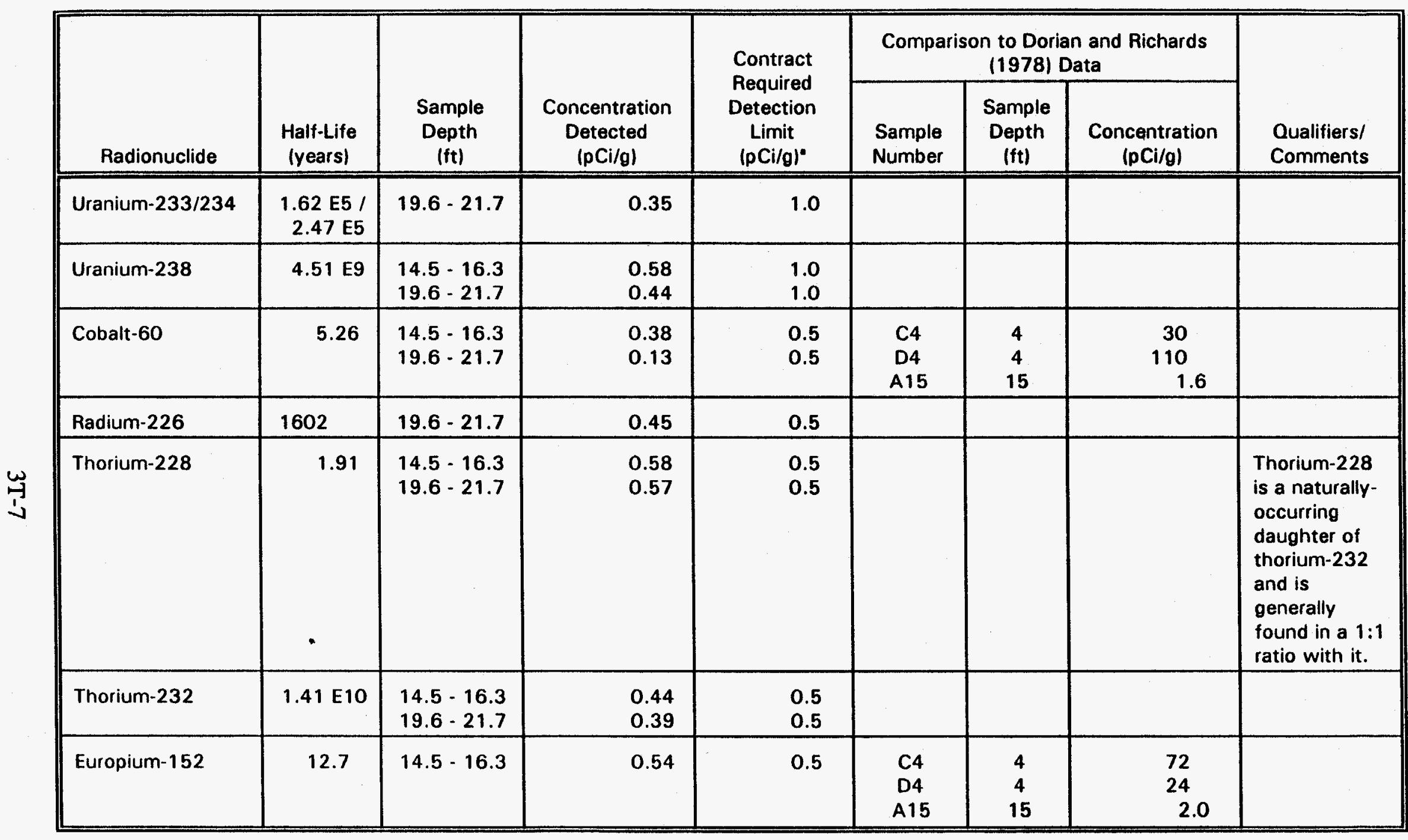


Table 3-8 Vadose Zone Borehole 116-H-7-Inorganic Analysis

\begin{tabular}{||c|c|c|c|c||}
\hline Analyte & $\begin{array}{c}\text { Sample } \\
\text { Depth } \\
(\mathrm{ft})\end{array}$ & $\begin{array}{c}\text { Concentration } \\
\text { Detected } \\
(\mathrm{mg} / \mathrm{kg})\end{array}$ & $\begin{array}{c}\text { Background } \\
95 \% \text { UTL } \\
(\mathrm{mg} / \mathrm{kg})\end{array}$ & $\begin{array}{c}\text { Qualifiers/ } \\
\text { Comments }\end{array}$ \\
\hline \hline Arsenic & $\begin{array}{c}1.0- \\
3.0\end{array}$ & 47 & 8.92 & \\
\hline Lead & $\begin{array}{c}1.0- \\
3.0\end{array}$ & 540 & 14.75 & \\
\hline
\end{tabular}

This table shows only those analytes that had levels above the 95 percent UTL. 
DOE/RL-93-51, Rev. 0

Table 3-9 Vadose Zone Borehole 116-H-7-Volatile Organic Analysis

\begin{tabular}{|c|c|c|c|c|}
\hline Analyte & $\begin{array}{c}\text { Sample } \\
\text { Depth } \\
(\mathrm{ft})\end{array}$ & $\begin{array}{c}\text { Concentration } \\
\text { Detected } \\
(\mu \mathrm{g} / \mathrm{kg})\end{array}$ & $\begin{array}{c}\text { Contract } \\
\text { Required } \\
\text { Quantitation } \\
\text { Limit } \\
(\mu \mathrm{g} / \mathrm{kg})^{\circ}\end{array}$ & \multicolumn{1}{|c|}{$\begin{array}{c}\text { Qualifiers/ } \\
\text { Comments }\end{array}$} \\
\hline \hline Toluene & $\begin{array}{c}8.0- \\
10.0\end{array}$ & 49 & 10.0 & $\begin{array}{l}\text { No other samples from } \\
\text { borehole had levels } \\
\text { above the detection } \\
\text { limit. Analyte is a } \\
\text { typical laboratory } \\
\text { contaminant and } \\
\text { detection is probably } \\
\text { laboratory } \\
\text { contamination. }\end{array}$ \\
\hline
\end{tabular}

This table shows only those analytes that had levels above the Contract Required Quantitation Limit.

'From QAPjP (DOE-RL 1992a). 


\begin{tabular}{|c|c|c|c|c|c|c|c|c|}
\hline Radionuclide & $\begin{array}{l}\text { Half-Life } \\
\text { (years) }\end{array}$ & $\begin{array}{l}\text { Sample } \\
\text { Depth } \\
\text { (ft) }\end{array}$ & $\begin{array}{c}\text { Concentration } \\
\text { Detected } \\
(\mathrm{pCi} / \mathrm{g})\end{array}$ & $\begin{array}{c}\text { Contract } \\
\text { Required } \\
\text { Detection Limit } \\
(\mathrm{pCi} / \mathrm{g})^{\mathrm{a}}\end{array}$ & $\begin{array}{c}\text { Sample } \\
\text { Number }\end{array}$ & $\begin{array}{l}\text { Sample } \\
\text { Depth } \\
\text { (ft) }\end{array}$ & $\begin{array}{c}\text { Concentration } \\
(\mathrm{pCl} / \mathrm{g})\end{array}$ & $\begin{array}{l}\text { Qualifiers/ } \\
\text { Comments }\end{array}$ \\
\hline Uranium-235 & $7.8 \mathrm{E} 8$ & $9.8-12.4$ & 0.38 & 1.0 & & & & \\
\hline Plutonium-239/240 & $\begin{array}{r}24,390 / \\
6580\end{array}$ & $\begin{array}{c}1.0-3.0 \\
8.0-10.0 \\
9.8-12.4 \\
14.8-16.4\end{array}$ & $\begin{array}{l}0.03 \\
1.10 \\
1.30 \\
0.07\end{array}$ & $\begin{array}{l}1.0 \\
1.0 \\
1.0 \\
1.0\end{array}$ & $\begin{array}{l}\text { L10 } \\
\text { K15 } \\
\text { B20 } \\
\text { I25 } \\
\end{array}$ & $\begin{array}{l}10 \\
15 \\
20 \\
25 \\
\end{array}$ & $\begin{array}{l}1.2 \\
0.16 \\
1.2 \\
0.50 \\
\end{array}$ & \\
\hline Strontium-90 & 27.7 & $8.0-10.0$ & 3.20 & 1.0 & $\begin{array}{l}\text { L10 } \\
\text { K15 } \\
\text { B20 } \\
\text { I25 }\end{array}$ & $\begin{array}{l}10 \\
15 \\
20 \\
25\end{array}$ & $\begin{array}{l}0.69 \\
4.1 \\
4.7 \\
0.87\end{array}$ & \\
\hline Cobalt -60 & 5.26 & $\begin{array}{c}8.0-10.0 \\
9.8-12.4 \\
14.8-16.4\end{array}$ & $\begin{array}{c}14.0 \\
36.0 \\
0.68\end{array}$ & $\begin{array}{l}0.5 \\
0.5 \\
0.5\end{array}$ & $\begin{array}{l}\mathrm{L} 10 \\
\mathrm{~K} 15 \\
\mathrm{~B} 20 \\
\mathrm{I25} \\
\end{array}$ & $\begin{array}{l}10 \\
15 \\
20 \\
25\end{array}$ & $\begin{array}{l}130 \\
100 \\
120 \\
300 \\
\end{array}$ & \\
\hline Cesium-137 & 30.0 & $\begin{array}{c}8.0-10.0 \\
9.8-12.4 \\
14.8-16.4\end{array}$ & $\begin{array}{r}11.0 \\
35.0 \\
1.7\end{array}$ & $\begin{array}{l}0.5 \\
0.5 \\
0.5\end{array}$ & $\begin{array}{l}\mathrm{L} 10 \\
\mathrm{~K} 15 \\
\mathrm{~B} 20 \\
\mathrm{I} 25\end{array}$ & $\begin{array}{l}10 \\
15 \\
20 \\
25\end{array}$ & $\begin{array}{l}67 \\
41 \\
18 \\
14\end{array}$ & \\
\hline
\end{tabular}




\begin{tabular}{|c|c|c|c|c|c|c|c|c|}
\hline \multirow[b]{2}{*}{ Radionuclide } & \multirow[b]{2}{*}{$\begin{array}{l}\text { Half-Life } \\
\text { (years) }\end{array}$} & \multirow[b]{2}{*}{$\begin{array}{c}\text { Sample } \\
\text { Depth } \\
\text { (ft) }\end{array}$} & \multirow[b]{2}{*}{$\begin{array}{c}\text { Concentration } \\
\text { Detected } \\
(\mathrm{pCi} / \mathrm{g})\end{array}$} & \multirow{2}{*}{$\begin{array}{l}\text { Contract } \\
\text { Required } \\
\text { Detection Limit } \\
(\mathrm{pCi} / \mathrm{g})^{\mathrm{a}}\end{array}$} & \multicolumn{3}{|c|}{$\begin{array}{l}\text { Comparison to Dorian and } \\
\text { Richards (1978) Data }\end{array}$} & \multirow[b]{2}{*}{$\begin{array}{l}\text { Qualifiers/ } \\
\text { Comments }\end{array}$} \\
\hline & & & & & $\begin{array}{l}\text { Sample } \\
\text { Number }\end{array}$ & $\begin{array}{l}\text { Sample } \\
\text { Depth } \\
\text { (ft) }\end{array}$ & $\begin{array}{l}\text { Concentration } \\
(\mathrm{pCi} / \mathrm{g})\end{array}$ & \\
\hline Radium-226 & 1602 & $\begin{array}{c}1.0-3.0 \\
14.8-16.4 \\
19.2-20.8 \\
\end{array}$ & $\begin{array}{l}0.29 \\
0.65 \\
0.44\end{array}$ & $\begin{array}{l}0.5 \\
0.5 \\
0.5\end{array}$ & & & & \\
\hline Thorium-228 & 1.91 & $\begin{array}{c}1.0-3.0 \\
14.8-16.4 \\
19.2-20.8\end{array}$ & $\begin{array}{l}0.41 \\
0.81 \\
0.46\end{array}$ & $\begin{array}{l}0.5 \\
0.5 \\
0.5\end{array}$ & & & & $\begin{array}{l}\text { Thorium-228 is } \\
\text { a naturally- } \\
\text { occurring } \\
\text { daughter of } \\
\text { thorium-232 } \\
\text { and is generally } \\
\text { found in a } 1: 1 \\
\text { ratio with it. }\end{array}$ \\
\hline Thorium-232 & $1.41 \mathrm{E} 10$ & $\begin{array}{c}1.0-3.0 \\
19.2-20.8\end{array}$ & $\begin{array}{l}0.41 \\
0.44\end{array}$ & $\begin{array}{l}0.5 \\
0.5\end{array}$ & & & & \\
\hline Europium-152 & 12.7 & $\begin{array}{c}8.0-10.0 \\
9.8-12.4 \\
14.8-16.4\end{array}$ & $\begin{array}{r}120.0 \\
260.0 \\
4.0\end{array}$ & $\begin{array}{l}0.5 \\
0.5 \\
0.5\end{array}$ & $\begin{array}{l}\text { L10 } \\
\text { K15 } \\
\text { B20 } \\
\text { I25 }\end{array}$ & $\begin{array}{l}10 \\
15 \\
20 \\
25\end{array}$ & $\begin{array}{r}160 \\
42 \\
160 \\
320\end{array}$ & \\
\hline Europium-154 & 16 & $\begin{array}{c}8.0-10.0 \\
9.8-12.4 \\
14.8-16.4\end{array}$ & $\begin{array}{c}19.0 \\
37.0 \\
0.50\end{array}$ & $\begin{array}{l}0.5 \\
0.5 \\
0.5\end{array}$ & $\begin{array}{l}\text { L10 } \\
\text { K15 } \\
\text { B20 } \\
\text { I25 }\end{array}$ & $\begin{array}{l}10 \\
15 \\
20 \\
25\end{array}$ & $\begin{array}{r}53 \\
16 \\
47 \\
110\end{array}$ & \\
\hline
\end{tabular}

âFrom QAPjP (DOE-RL 1992a). 
DOE/RL-93-51, Rev. 0

Table 3-11 Vadose Zone Borehole 116-H-9-Radionuclide Analysis

\begin{tabular}{|c|c|c|c|c|c|}
\hline Radionuclide & $\begin{array}{l}\text { Half-Life } \\
\text { (years) }\end{array}$ & $\begin{array}{l}\text { Sample } \\
\text { Depth } \\
\text { (ft) }\end{array}$ & $\begin{array}{l}\text { Concentration } \\
\text { Detected } \\
\text { (pCl/g) }\end{array}$ & $\begin{array}{l}\text { Contract } \\
\text { Required } \\
\text { Detection Limit } \\
(\mathrm{pCi} / \mathrm{g})^{\mathrm{a}}\end{array}$ & $\begin{array}{l}\text { Qualifiers/ } \\
\text { Comments }\end{array}$ \\
\hline Uranium-238 & 4.51 E9 & $\begin{array}{c}3.1-5.3 \\
21.7-24.2\end{array}$ & $\begin{array}{l}0.47 \\
0.45\end{array}$ & $\begin{array}{l}1.0 \\
1.0 \\
\end{array}$ & \\
\hline Cesium-137 & 30.0 & $17.6-20.1$ & 0.29 & 0.5 & \\
\hline Radium-226 & 1602 & $\begin{array}{c}3.1-5.3 \\
17.6-20.1 \\
21.7-24.2\end{array}$ & $\begin{array}{l}0.64 \\
0.71 \\
0.50\end{array}$ & $\begin{array}{l}0.5 \\
0.5 \\
0.5\end{array}$ & \\
\hline Thorium-228 & 1.91 & $\begin{array}{c}3.1-5.3 \\
17.6-20.1 \\
21.7-24.2\end{array}$ & $\begin{array}{l}1.20 \\
1.10 \\
0.73\end{array}$ & $\begin{array}{l}0.5 \\
0.5 \\
0.5\end{array}$ & $\begin{array}{l}\text { Thorium-228 is a } \\
\text { naturally- } \\
\text { occurring } \\
\text { daughter of } \\
\text { thorium-232 and } \\
\text { is generally found } \\
\text { in a } 1: 1 \text { ratio }\end{array}$ \\
\hline Thorium-232 & $1.41 \mathrm{E} 10$ & $\begin{array}{r}3.1-5.3 \\
17.6-20.1 \\
21.7-24.2 \\
\end{array}$ & $\begin{array}{l}0.75 \\
1.10 \\
0.39 \\
\end{array}$ & $\begin{array}{l}0.5 \\
0.5 \\
0.5 \\
\end{array}$ & \\
\hline Europium-152 & 12.7 & $17.6-20.1$ & 0.36 & 0.5 & \\
\hline
\end{tabular}

There were no radionuclides detected in both LFI vadose borehole analysis data and Dorian and Richards (1978) historical data to allow a comparison.

${ }^{a}$ From QAPjP (DOE-RL 1992a). 
DOE/RL-93-51, Rev. 0

Table 3-12 116-H-5 Process Effluent Outfall StructureAnalogous Data from 116-D-5 Outfall Structure

\begin{tabular}{||c|c|c|c|c||}
\hline \multicolumn{1}{|c|}{ Analyte } & $\begin{array}{c}\text { Sample } \\
\text { Depth } \\
\text { (ft) }\end{array}$ & $\begin{array}{c}\text { Concentration } \\
\text { Detected } \\
(\mu \mathrm{g} / \mathrm{kg})\end{array}$ & $\begin{array}{c}\text { Contract } \\
\text { Required } \\
\text { Quantitation } \\
\text { Limit } \\
(\mu \mathrm{g} / \mathrm{kg})^{\circ}\end{array}$ & $\begin{array}{c}\text { Qualifiers/ } \\
\text { Comments }\end{array}$ \\
\hline $\begin{array}{l}\text { Bis(2-ethylhexyl) } \\
\text { phthalate }\end{array}$ & 25 & 5200 & 330.0 & \\
\hline $\begin{array}{l}\text { Butyl } \\
\text { benzylphthalate }\end{array}$ & 25 & 2500 & 330.0 & \\
\hline
\end{tabular}

This table shows only those analytes that had levels above the Contract Required Quantitation Limit.

'From QAPjP (DOE-RL, 1992a). 
DOE/RL-93-51, Rev. 0

Table 3-13 Septic Tank 1607-H-2-Inorganic Analysis

\begin{tabular}{|c|c|c|c|c|}
\hline Analyte & $\begin{array}{l}\text { Sludge } \\
\text { Sample } \\
\text { Number } \\
\end{array}$ & $\begin{array}{c}\text { Concentration } \\
\text { Detected } \\
\text { (mg/kg) } \\
\end{array}$ & $\begin{array}{c}\text { Background } \\
95 \% \text { UTL } \\
\text { (mg/kg) } \\
\end{array}$ & $\begin{array}{l}\text { Qualifiers/ } \\
\text { Comments }\end{array}$ \\
\hline Antimony & BOOZM7 & 18.6 & 15.7 & \\
\hline Arsenic & B00ZM6 & 24.1 & 8.92 & \\
\hline Barium & $\begin{array}{l}\text { B00ZM6 } \\
\text { BOOZM7 }\end{array}$ & $\begin{array}{l}1930 \\
4260\end{array}$ & 171 & \\
\hline Cadmium & $\begin{array}{l}\text { BOOZM6 } \\
\text { BOOZM7 }\end{array}$ & $\begin{array}{l}22.5 \\
28.5 \\
\end{array}$ & 0.66 & \\
\hline Chromium & $\begin{array}{l}\text { BOOZM6 } \\
\text { BOOZM7 }\end{array}$ & $\begin{array}{l}1020 \\
2510 \\
\end{array}$ & 27.9 & \\
\hline Copper & $\begin{array}{l}\text { BOOZM6 } \\
\text { BOOZM7 }\end{array}$ & $\begin{array}{l}534 \\
627\end{array}$ & 28.2 & \\
\hline Lead & $\begin{array}{l}\text { BOOZM6 } \\
\text { BOOZM7 }\end{array}$ & $\begin{array}{l}419 \\
499 \\
\end{array}$ & 14.75 & \\
\hline Mercury & $\begin{array}{l}\text { BOOZM6 } \\
\text { BOOZM7 }\end{array}$ & $\begin{array}{l}34.1 \\
37.0 \\
\end{array}$ & 1.25 & \\
\hline Nickel & $\begin{array}{l}\text { BOOZM6 } \\
\text { BOOZM7 }\end{array}$ & $\begin{array}{l}56.4 \\
51.2\end{array}$ & 25.3 & \\
\hline Selenium & BOOZM6 & 7.8 & 5 & \\
\hline Silver & $\begin{array}{l}\text { BOOZM6 } \\
\text { BOOZM7 }\end{array}$ & $\begin{array}{l}119 \\
107 \\
\end{array}$ & 2.7 & \\
\hline Thallium & BOOZM7 & 5.4 & 3.7 & \\
\hline Zinc & $\begin{array}{l}\text { BOOZM6 } \\
\text { BOOZM7 }\end{array}$ & $\begin{array}{l}4080 \\
6160 \\
\end{array}$ & 79 & \\
\hline Sulfate & $\begin{array}{l}\text { BOOZM6 } \\
\text { BOOZM7 }\end{array}$ & $\begin{array}{l}4425 \\
7115\end{array}$ & 1320 & \\
\hline
\end{tabular}

This table shows only those analytes that had levels above the 95 percent UTL. 
DOE/RL-93-51, Rev. 0

Table 3-14 Septic Tank 1607-H-2-Volatile Organic Analysis

\begin{tabular}{|c|c|c|c|c|}
\hline Analyte & $\begin{array}{c}\text { Sample } \\
\text { Number }\end{array}$ & $\begin{array}{c}\text { Concentration } \\
\text { Detected } \\
(\mu \mathrm{g} / \mathrm{liter})\end{array}$ & $\begin{array}{c}\text { Contract } \\
\text { Required } \\
\text { Quantitation } \\
\text { Limit } \\
(\mu \mathrm{g} / \text { liter })^{\mathrm{a}}\end{array}$ & \multicolumn{1}{c|}{$\begin{array}{c}\text { Qualifiers/ } \\
\text { Comments }\end{array}$} \\
\hline \hline $\begin{array}{c}\text { Methylene } \\
\text { Chloride }\end{array}$ & $\begin{array}{c}\text { B01609 } \\
\text { (Water } \\
\text { sample) }\end{array}$ & 300 & 10.0 & $\begin{array}{l}\text { No other samples from } \\
\text { septic tank had levels } \\
\text { above the detection } \\
\text { limit for this analyte. } \\
\text { Analyte detection may } \\
\text { be result of laboratory } \\
\text { contamination. }\end{array}$ \\
\hline
\end{tabular}

This table shows only those analytes that had levels above the Contract Required Quantitation Limit.

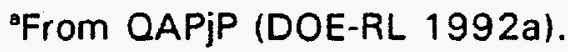


DOE/RL-93-51, Rev. 0

Table 3-15 Septic Tank 1607-H-2 - Radionuclide Analysis

\begin{tabular}{|c|c|c|c|c|c|}
\hline Radionuclide & $\begin{array}{l}\text { Half-Life } \\
\text { (years) }\end{array}$ & $\begin{array}{l}\text { Sludge } \\
\text { Sample } \\
\text { Number }\end{array}$ & $\begin{array}{l}\text { Concentration } \\
\text { Detected } \\
(\mathrm{pCi} / \mathrm{g})\end{array}$ & $\begin{array}{l}\text { Contract } \\
\text { Required } \\
\text { Detection Limit } \\
(\mathrm{pCi} / \mathrm{g})^{\mathrm{a}}\end{array}$ & $\begin{array}{l}\text { Qualifiers/ } \\
\text { Comments }\end{array}$ \\
\hline Cobalt $=60$ & 5.26 & $\begin{array}{l}\text { B00ZM6 } \\
\text { B00ZM7 }\end{array}$ & $\begin{array}{l}0.48 \\
1.38\end{array}$ & $\begin{array}{l}0.5 \\
0.5\end{array}$ & \\
\hline Cesium-137 & 30.0 & $\begin{array}{l}\text { B00ZM6 } \\
\text { B00ZM7 }\end{array}$ & $\begin{array}{l}0.87 \\
0.75\end{array}$ & $\begin{array}{l}0.5 \\
0.5\end{array}$ & \\
\hline Radium-226 & 1602 & $\begin{array}{l}\text { B00ZM6 } \\
\text { B00ZM7 }\end{array}$ & $\begin{array}{l}0.68 \\
1.36\end{array}$ & $\begin{array}{l}0.5 \\
0.5\end{array}$ & \\
\hline Thorium-228 & 1.91 & $\begin{array}{l}\text { B00ZM6 } \\
\text { B00ZM7 }\end{array}$ & $\begin{array}{l}0.86 \\
0.91\end{array}$ & $\begin{array}{l}0.5 \\
0.5\end{array}$ & $\begin{array}{l}\text { Thorium-228 is a } \\
\text { naturally- } \\
\text { occurring } \\
\text { daughter of } \\
\text { thorium- } 232 \text { and } \\
\text { is generally found } \\
\text { in a } 1: 1 \text { ratio }\end{array}$ \\
\hline Thorium-232 & 1.41 E10 & $\begin{array}{l}\text { B00ZM6 } \\
\text { B00ZM7 }\end{array}$ & $\begin{array}{l}1.43 \\
2.04\end{array}$ & $\begin{array}{l}0.5 \\
0.5\end{array}$ & \\
\hline Europium-152 & 12.7 & $\begin{array}{l}\text { B00ZM6 } \\
\text { B00ZM7 }\end{array}$ & $\begin{array}{l}0.95 \\
1.12\end{array}$ & $\begin{array}{l}0.5 \\
0.5\end{array}$ & \\
\hline
\end{tabular}

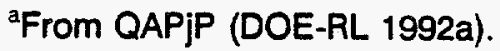


DOE/RL-93-51, Rev. 0

Table 3-16 Septic Tank 1607-H-4-Inorganic Analysis

\begin{tabular}{|l|c|c|c|c|}
\hline \multicolumn{1}{|c|}{ Analyte } & $\begin{array}{c}\text { Sample } \\
\text { Number }\end{array}$ & $\begin{array}{c}\text { Concentration } \\
\text { Detected } \\
\text { (mg/kg) }\end{array}$ & $\begin{array}{c}\text { Background } \\
95 \% \text { UTL } \\
\text { (mg/kg) }\end{array}$ & $\begin{array}{c}\text { Qualifiers/ } \\
\text { Comments }\end{array}$ \\
\hline \hline Barium & B07211 & 226 & 171 & \\
\hline Copper & $B 07211$ & 40.2 & 28.2 & \\
\hline Lead & B07211 & 50.0 & 14.75 & \\
\hline Zinc & B07211 & 194 & 79 & \\
\hline
\end{tabular}

This table shows only those analytes that had levels above the 95 percent UTL. 
DOE/RL-93-51, Rev. 0

Table 3-17 Septic Tank 1607-H-4-Volatile Organic Analysis

\begin{tabular}{|c|c|c|c|c|}
\hline Analyte & $\begin{array}{c}\text { Sample } \\
\text { Number }\end{array}$ & $\begin{array}{c}\text { Concentration } \\
\text { Detected } \\
(\mu \mathrm{g} / \mathrm{kg})\end{array}$ & $\begin{array}{c}\text { Contract } \\
\text { Required } \\
\text { Quantitation } \\
\text { Limit } \\
(\mu \mathrm{g} / \mathrm{kg})^{\circ}\end{array}$ & \multicolumn{1}{|c|}{$\begin{array}{c}\text { Qualifiers/ } \\
\text { Comments }\end{array}$} \\
\hline \hline Acetone & B07208 & 17 & 10.0 & $\begin{array}{l}\text { Analyte detected in } \\
\text { laboratory blanks } \\
\text { associated with other } \\
\text { samples taken from } \\
\text { site. Analyte is a } \\
\text { typical laboratory } \\
\text { contaminant. } \\
\text { Detection here is } \\
\text { probably due to } \\
\text { laboratory } \\
\text { contamination. }\end{array}$ \\
\hline
\end{tabular}

This table shows only those analytes that had levels above the Contract Required Quantitation Limit.

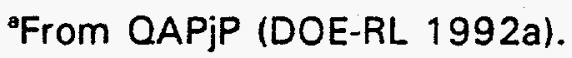


DOE/RL-93-51, Rev. 0

Table 3-18 Septic Tank 1607-H-4-Semivolatile Organic Analysis

\begin{tabular}{||l|c|c|c|c||}
\hline \hline \multicolumn{1}{|c|}{ Analyte } & $\begin{array}{c}\text { Sample } \\
\text { Number }\end{array}$ & $\begin{array}{c}\text { Concentration } \\
\text { Detected } \\
(\mu \mathrm{g} / \mathrm{kg})\end{array}$ & $\begin{array}{c}\text { Contract } \\
\text { Required } \\
\text { Quantitation } \\
\text { Limit } \\
(\mu \mathrm{g} / \mathrm{kg})^{\mathrm{a}}\end{array}$ & $\begin{array}{c}\text { Qualifiers/ } \\
\text { Comments }\end{array}$ \\
\hline \hline Carbazole & $B 07211$ & 150 & 330.0 & \\
Anthracene & $B 07211$ & 320 & 330.0 & \\
Benzo(a)anthracene & $B 07211$ & 1800 & 330.0 & \\
Benzo(a)pyrene & $B 07211$ & 940 & 330.0 & \\
Benzo(b)fluoranthene & $B 07211$ & 2400 & 330.0 & \\
Benzo(ghi)perylene & $B 07211$ & 460 & 330.0 & \\
Chrysene & $B 07211$ & 920 & 330.0 & \\
Fluoranthene & $B 07211$ & 2900 & 330.0 & \\
Fluorene & $B 07211$ & 110 & 330.0 & \\
Indeno(1,2,3-cd)pyrene & $B 07211$ & 480 & 330.0 & \\
Phenanthrene & $B 07211$ & 1600 & 330.0 & \\
Acenaphthene & $B 07211$ & 130 & 330.0 & \\
Pyrene & $B 07211$ & 2700 & 330.0 & \\
\hline
\end{tabular}

This table shows only those analytes that had levels above the Contract Required Quantitation Limit. ${ }^{2}$ From QAPjP (DOE-RL 1992a). 
DOE/RL-93-51, Rev. 0

Table 3-19 Septic Tank 1607-H-4 - Pesticide Analysis

\begin{tabular}{||l|c|c|c|c||}
\hline \multicolumn{1}{|c|}{ Analyte } & $\begin{array}{c}\text { Sample } \\
\text { Number }\end{array}$ & $\begin{array}{c}\text { Concentration } \\
\text { Detected } \\
(\mu \mathrm{g} / \mathrm{kg})\end{array}$ & $\begin{array}{c}\text { Contract } \\
\text { Required } \\
\text { Detection } \\
\text { Limit } \\
(\mu \mathrm{g} / \mathrm{kg})^{\circ}\end{array}$ & $\begin{array}{c}\text { Qualifiers/ } \\
\text { Comments }\end{array}$ \\
\hline \hline $44^{\prime}$ - DDD & B07211 & 110 & 3.3 & \\
$4,4^{\prime}-$ DDE & $B 07211$ & 12.0 & 3.3 & \\
gamma- & Bo7211 & 18.0 & 1.7 & \\
\hline
\end{tabular}

This table shows only those analytes that had levels above the Contract Required Detection limit.

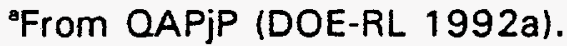


DOE/RL-93-51, Rev. 0

Table 3-20 Septic Tank 1607-H-4 - Radionuclide Analysis

\begin{tabular}{|c|c|c|c|c|c|}
\hline Radionuclide & $\begin{array}{c}\text { Half-Life } \\
\text { (years) }\end{array}$ & $\begin{array}{l}\text { Sample } \\
\text { Number }\end{array}$ & $\begin{array}{c}\text { Concentration } \\
\text { Detected } \\
(\mathrm{pCi} / \mathrm{g})\end{array}$ & $\begin{array}{l}\text { Contract } \\
\text { Required } \\
\text { Detection Limit } \\
(\mathrm{pCi} / \mathrm{g})^{\mathrm{a}}\end{array}$ & $\begin{array}{l}\text { Qualifiers/ } \\
\text { Comments }\end{array}$ \\
\hline $\begin{array}{l}\text { Uranium- } \\
233 / 234\end{array}$ & $\begin{array}{r}1.62 \text { E5 / } \\
2.47 \text { E5 }\end{array}$ & $\begin{array}{l}\text { B07206 } \\
\text { B07208 } \\
B 07211\end{array}$ & $\begin{array}{l}0.57 \\
0.41 \\
0.62\end{array}$ & 1.0 & \\
\hline Uranium-238 & 4.51 E9 & $\begin{array}{l}B 07206 \\
B 07208 \\
B 07211\end{array}$ & $\begin{array}{l}0.48 \\
0.44 \\
0.31\end{array}$ & 1.0 & \\
\hline Cesium-137 & 30.0 & B07211 & 0.67 & 0.5 & \\
\hline Radium-226 & 1602 & $\begin{array}{l}\text { B07206 } \\
\text { B07208 } \\
B 07211\end{array}$ & $\begin{array}{l}0.45 \\
0.44 \\
0.37\end{array}$ & 0.5 & \\
\hline Thorium-228 & 1.91 & $\begin{array}{l}\text { B07206 } \\
\text { B07208 } \\
B 07211\end{array}$ & $\begin{array}{l}0.54 \\
0.56 \\
0.40\end{array}$ & 0.5 & $\begin{array}{l}\text { Thorium-228 is a } \\
\text { naturally- } \\
\text { occurring } \\
\text { daughter of } \\
\text { thorium- } 232 \text { and } \\
\text { is generally found } \\
\text { in a } 1: 1 \text { ratio with } \\
\text { it. }\end{array}$ \\
\hline Thorium-232 & $1.41 \mathrm{E} 10$ & $\begin{array}{l}\text { B07206 } \\
\text { B07208 } \\
\text { B07211 }\end{array}$ & $\begin{array}{l}0.51 \\
0.62 \\
0.44\end{array}$ & 0.5 & \\
\hline Europium-152 & 12.7 & B07211 & 1.2 & 0.5 & \\
\hline
\end{tabular}

${ }^{\text {a}}$ From QAPjP (DOE-RL 1992a). 
DOE/RL-93-51, Rev. 0

Table 3-21 Electrical Facilities - PCB Analysis

\begin{tabular}{|c|c|c|c|}
\hline Analyte & $\begin{array}{c}\text { Sample } \\
\text { Number }\end{array}$ & $\begin{array}{c}\text { Concentration } \\
\text { Detected } \\
(\mu \mathrm{gg} / \mathrm{kg})\end{array}$ & $\begin{array}{c}\text { Qualifiers/ } \\
\text { Comments }\end{array}$ \\
\hline \hline Aroclor-1254 & B018S8 & 350 & \\
& B018T0 & 32 & \\
Aroclor-1260 & B018S5 & 1200 & \\
& B018S6 & 770 & \\
& B018S7 & 630 & \\
\hline
\end{tabular}




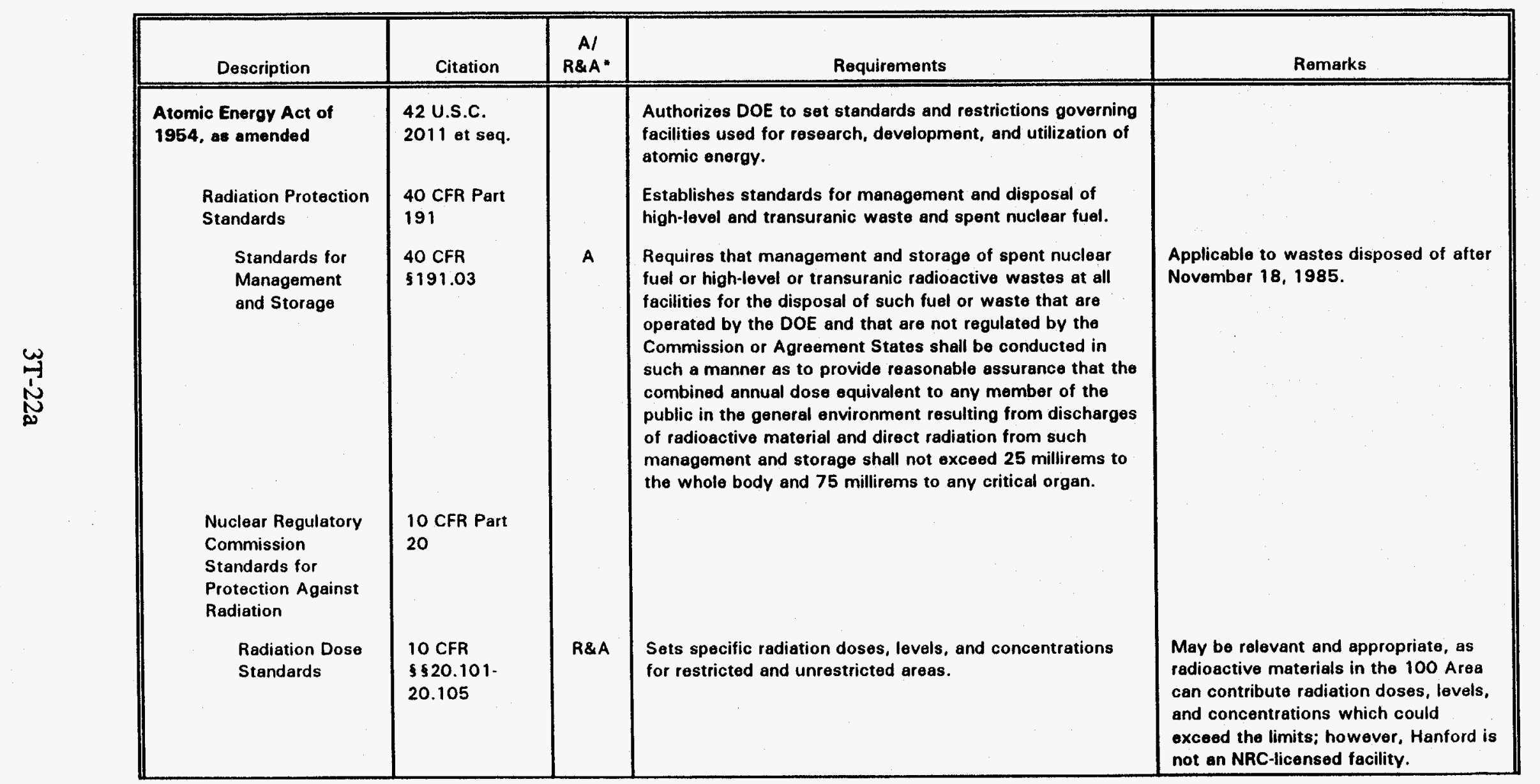


DOE/RL-93-51, Rev. 0

Table 3-22 Potential Federal Chemical-Specific Applicable or Relevant and Appropriate Requirements for the 100-HR-1 Operable Unit (page 2 of 3)

\begin{tabular}{|c|c|c|c|c|c|}
\hline 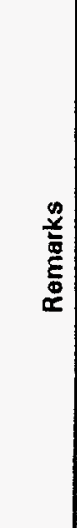 & & 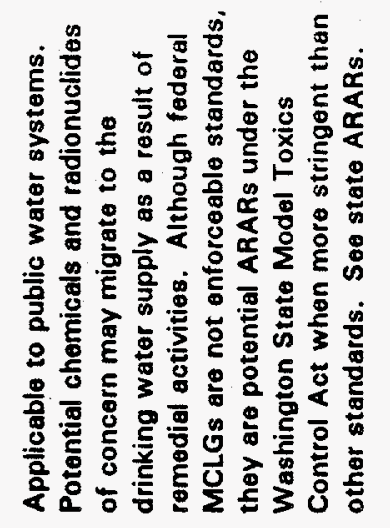 & 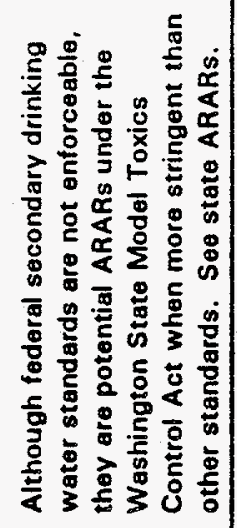 & & 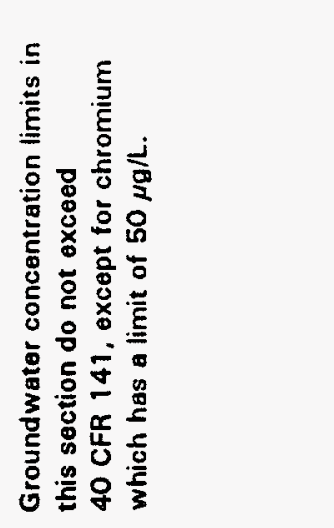 \\
\hline 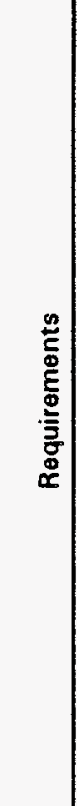 & 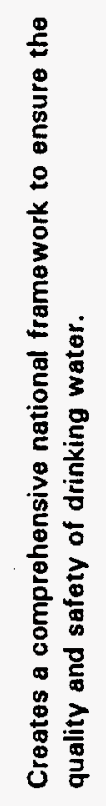 & 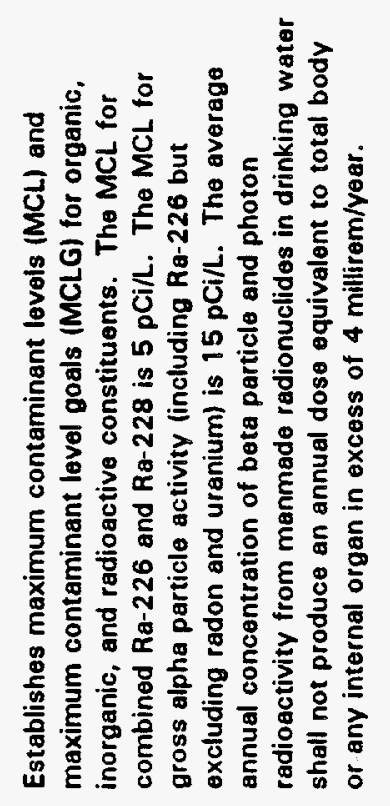 & 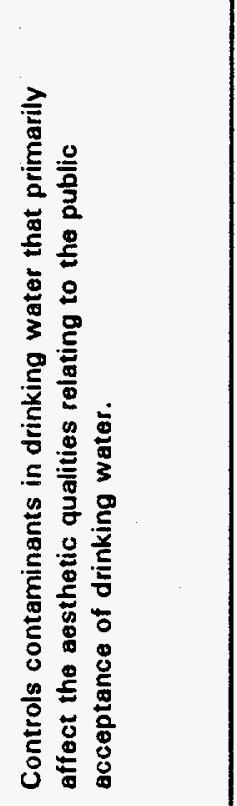 & 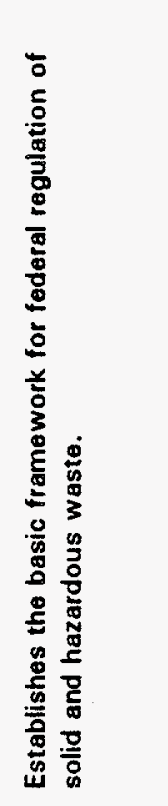 & 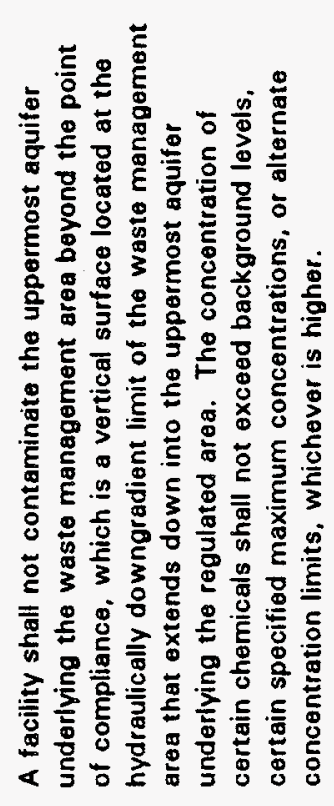 \\
\hline$<\underset{\alpha \approx}{\alpha}$ & & 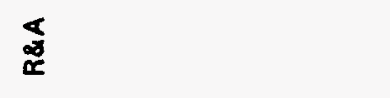 & $\underset{\varpi}{\nwarrow}$ & & $\alpha$ \\
\hline 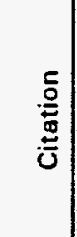 & 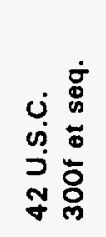 & 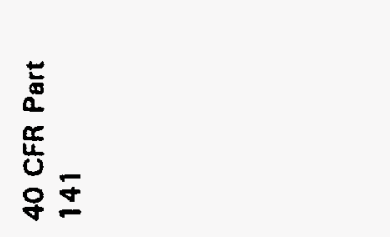 & 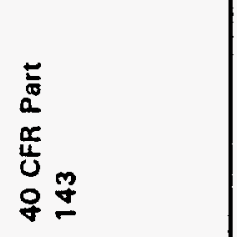 & 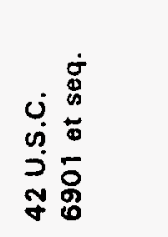 & 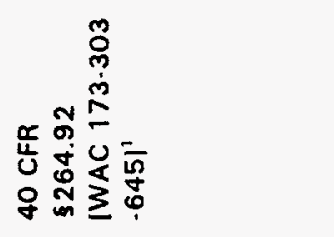 \\
\hline 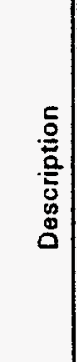 & 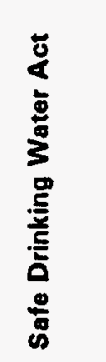 & 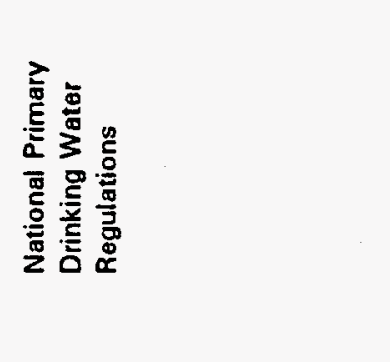 & 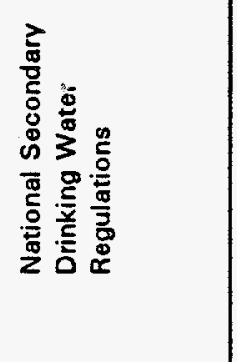 & 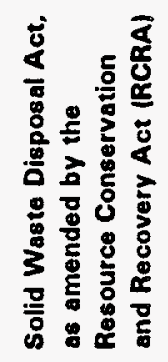 & 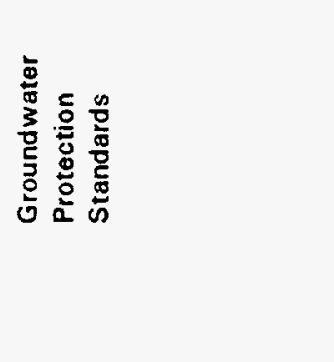 \\
\hline
\end{tabular}




\begin{tabular}{|c|c|c|c|c|}
\hline Description & Citation & $\begin{array}{r}A / \\
R \& A^{*} \\
\end{array}$ & Requirements & Remarks \\
\hline $\begin{array}{l}\text { Uranium Mill Tailings } \\
\text { Radiation Control Act of } \\
\text { 1978 } \\
\text { Standards for } \\
\text { Uranium and } \\
\text { Thorium Mill } \\
\text { Tailings }\end{array}$ & $\begin{array}{l}\text { Public Law } \\
95-604 \text {, as } \\
\text { amended } \\
40 \text { CFR } 192\end{array}$ & & $\begin{array}{l}\text { Establishes standards for control, cleanup, and } \\
\text { management of radioactive materials from inactive } \\
\text { uranium processing sites. }\end{array}$ & \\
\hline $\begin{array}{l}\text { Land Cleanup } \\
\text { Standards }\end{array}$ & $\begin{array}{l}40 \mathrm{CFR} \\
\$ 5192.10 \\
192.12\end{array}$ & R\&A & $\begin{array}{l}\text { Requires remedial actions to provide reasonable assurance } \\
\text { that, as a result of residual radioactive materials from any } \\
\text { designated processing site. the concentration of } \\
\text { radiumm-226 in land averaged over any area of } 100 \text { square } \\
\text { meters shall not axced the background lavel by more than } \\
5 \mathrm{pCi} / \mathrm{g} \text {, averaged over the first } 15 \mathrm{~cm} \text { of soil below the } \\
\text { surface, and } 15 \mathrm{pCi} / \mathrm{g} \text {, averaged over } 15 \text {-cm-thick layers of } \\
\text { soil more than } 15 \mathrm{~cm} \text { below the surface. In any habitable } \\
\text { building, a reasonable effort shall be made during } \\
\text { remediation to achieve an annual average (or equivalent) } \\
\text { radon decay product concentration (including background) } \\
\text { not to exceed } 0.02 \text { Working Level (WL). In any case, the } \\
\text { radon decay product concentration (including background) } \\
\text { shall not exceed } 0.03 \text { WL and the level of gamma radiation } \\
\text { shall not exceed the background level by more than } 20 \\
\text { microroentegens per hour. }\end{array}$ & $\begin{array}{l}\text { May be relovant and appropriate, as } \\
\text { any radium- } 226 \text { encountered during } \\
\text { remediation did not result from } \\
\text { uranium processing. }\end{array}$ \\
\hline Implementation & $\begin{array}{l}40 \text { CFR } \\
55192.20 \\
192.23\end{array}$ & R\&A & $\begin{array}{l}\text { Requires that when radionuclides other than radium- } 226 \\
\text { and its decay products are present in sufficiont quantity } \\
\text { and concentration to constitute a significant radiation } \\
\text { hazard from residual radioactive materials, remedial action } \\
\text { shall reduce other residual radioactivity to levels as low as } \\
\text { reasonably achievable (ALARA). }\end{array}$ & $\begin{array}{l}\text { May be relevant and appropriate, as } \\
\text { any radium- } 226 \text { oncountered during } \\
\text { remediation did not result from } \\
\text { uranium processing. }\end{array}$ \\
\hline
\end{tabular}




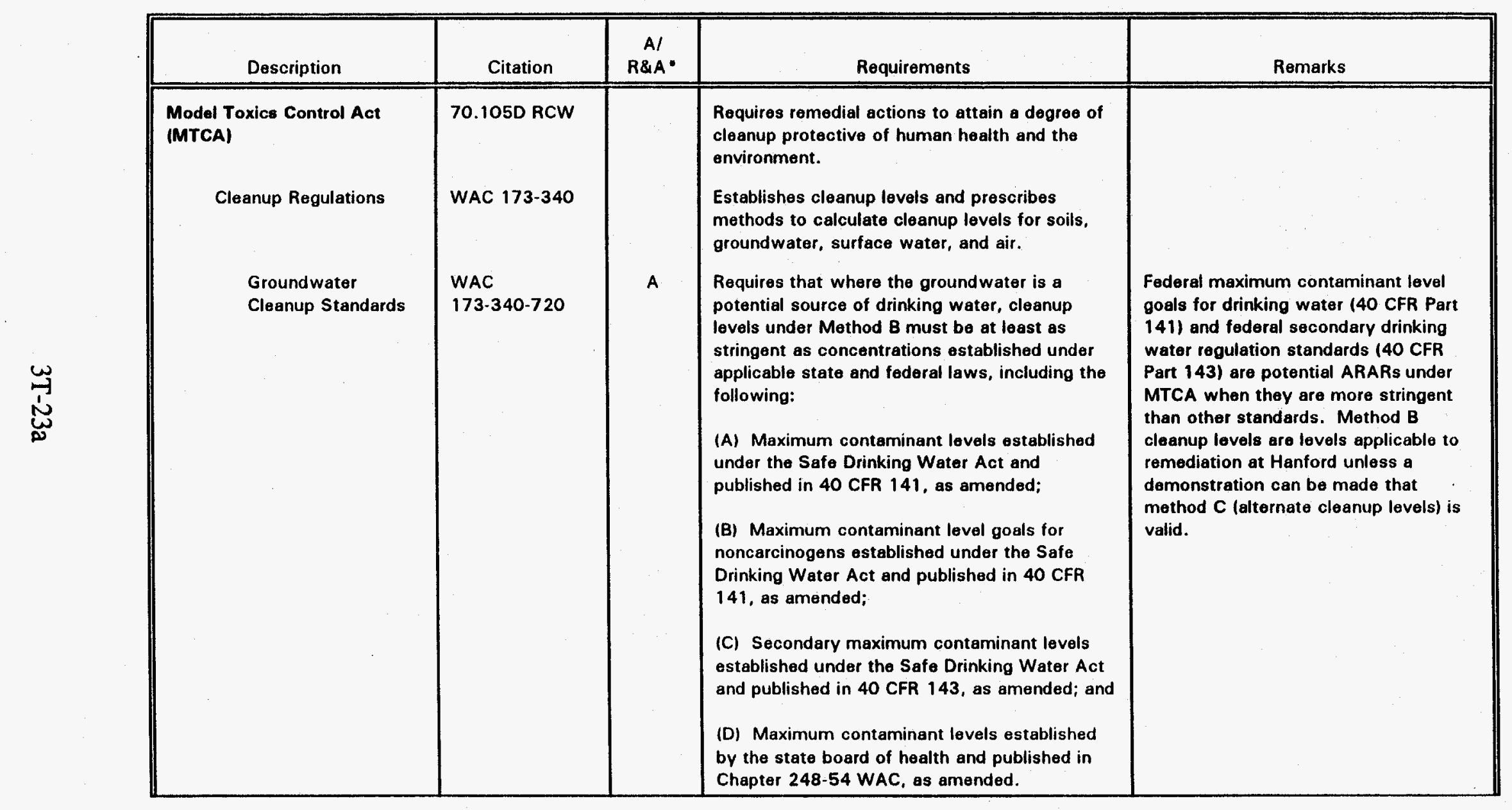




\begin{tabular}{|c|c|c|c|c|}
\hline Description & Citation & $\begin{array}{c}\text { A/ } \\
R \& A\end{array}$ & Requirements & Remarks \\
\hline $\begin{array}{l}\text { Soil Cleanup } \\
\text { Standards }\end{array}$ & $\begin{array}{l}\text { WAC } \\
173-340-740\end{array}$ & A & $\begin{array}{lc}\text { MTCA Method B concentration limits in } \\
\text { milligrams per kilogram for potential } \\
\text { contaminants in soils, sediments, and sludges } \\
\text { are: } \\
\text { Barium } \\
\text { Cadmium } & 5,600 \\
\text { Chromium (III) } & 40 \\
\text { Chromium (VI) } & 80,000 \\
\text { Copper } & 400 \\
\text { Manganese } & 2,960 \\
\text { Mercury } & 8,000 \\
\text { Silver } & 24 \\
\text { Zinc } & 240 \\
\text { Acetone } & 16,000 \\
\text { Benzene } & 8,000 \\
\text { Carbon disulfide } & 34.5 \\
\text { Methyl ethyl ketone } & 8,000 \\
\text { Methyl lsobutyl Ketone } & 4,000 \\
\text { Methylene chloride } & 4,000 \\
\text { Toluene } & 133 \\
\text { Anthracene } & 16,000 \\
\text { Benzo(a)anthracene } & 24,000 \\
\text { Benzo(b)fluoranthene } & 0.172 \\
\text { Benzo(k)fluoranthene } & 0.172 \\
\text { Benzoic acid } & 0.172 \\
\text { Benzyl alcohol } & 320,000 \\
\text { Bis(2-ethylhexyl)phthalate } & 24,000 \\
\text { Chrysene } & 71.4 \\
\text { Di-n-butylphthalate } & 0.172 \\
\text { Diethyl phthalate } & 8,000 \\
\text { Fluoranthene } & 64,000 \\
\text { N-nitrosodiphenylamine } & 3,200 \\
\text { Pyrene } & 204 \\
\text { Pentachlorophenol } & 2040 \\
& 8.33 \\
\end{array}$ & \\
\hline
\end{tabular}




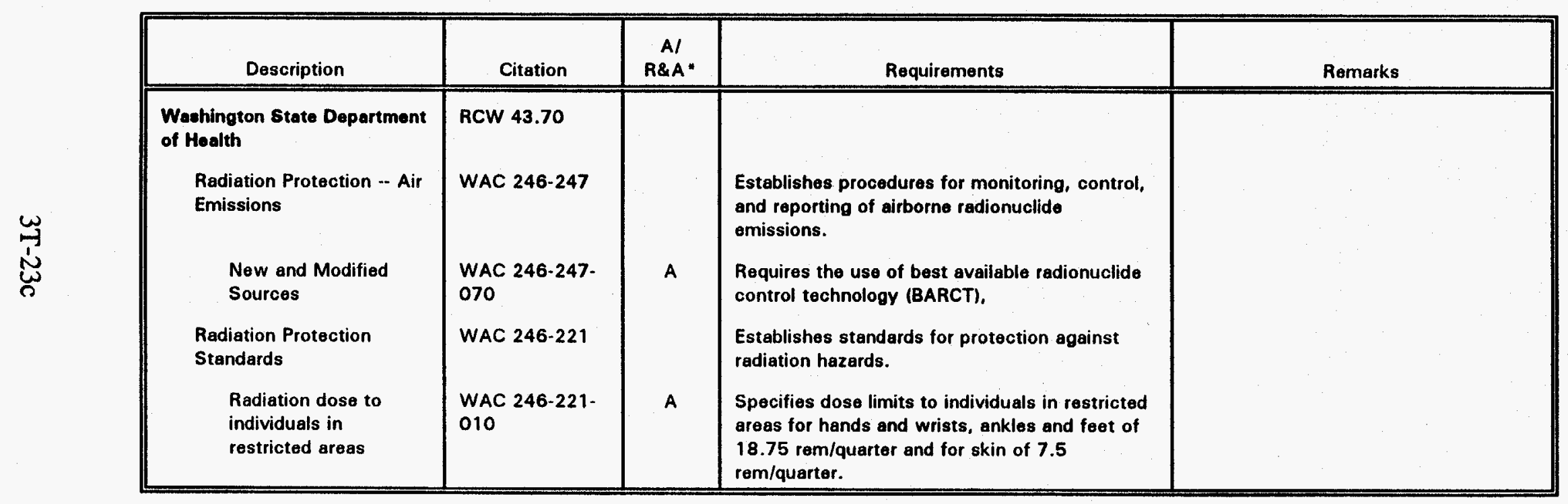

"NOTE: $A=$ Applicable, R\&A = Relevant and Appropriate 


\begin{tabular}{|c|c|c|c|}
\hline Description & Citation & Requirements & Remarks \\
\hline $\begin{array}{l}\text { Madel Toxics Control Act } \\
\text { Cleanup Regulations }\end{array}$ & $\begin{array}{l}\text { 70.105D RCW } \\
\text { WAC 173-340 }\end{array}$ & $\begin{array}{l}\text { The State Department of Ecology is currently adapting } \\
\text { the calculations in MTCA to be applicable to } \\
\text { radioactive contaminants. These cleanup standards } \\
\text { may become available prior to or during remediation. }\end{array}$ & \\
\hline $\begin{array}{l}\text { Solid Waste Disposal Act, as } \\
\text { amended by RCRA } \\
\text { Criteria for Classification } \\
\text { of Solid Waste Disposal } \\
\text { Facilities and Practices } \\
\text { Corrective Action for Solid } \\
\text { Waste Management Units }\end{array}$ & $\begin{array}{l}42 \text { U.S.C. } 6901 \\
\text { et seq. } \\
40 \text { CFR } \$ 257.3-4 \\
40 \text { CFR } 264 \\
\text { Subpart S. } \\
\text { proposed }\end{array}$ & $\begin{array}{l}\text { A facility or practice shall not contaminate an } \\
\text { underground drinking water source beyond the solid } \\
\text { waste boundary. } \\
\text { Estabilishes requirements for investigation and } \\
\text { corrective action for releases of hazardous waste from } \\
\text { solid waste management units. }\end{array}$ & $\begin{array}{l}\text { The courts or the state may establish } \\
\text { alternate boundaries. }\end{array}$ \\
\hline $\begin{array}{l}\text { U.S. Department of Energy } \\
\text { Orders } \\
\text { Radiation Protection of the } \\
\text { Public and the } \\
\text { Environment }\end{array}$ & DOE 5400.5 & $\begin{array}{l}\text { Establishes radiation protection standards for the } \\
\text { public and environment. }\end{array}$ & \\
\hline $\begin{array}{l}\text { Radiation Dose Limit (All } \\
\text { Pathways) } \\
\text { Radiation Dose Limit } \\
\text { (Drinking Water Pathway) }\end{array}$ & $\begin{array}{l}\text { DOE } 5400.5 \text {, } \\
\text { Chapter 1I, } \\
\text { Section 1a } \\
\text { DOE } 5400.5 \text {, } \\
\text { Chapter II, } \\
\text { Section 1d }\end{array}$ & $\begin{array}{l}\text { The exposure of the public to radiation sources as a } \\
\text { consequence of all routine DOE activities shall not } \\
\text { cause, in a year, an effective dose equivalent greater } \\
\text { than } 100 \text { mrem from all exposure pathways, except } \\
\text { under specified circumstances. } \\
\text { Provides a level of protection for persons consuming } \\
\text { water from a public drinking water supply operated by } \\
\text { DOE so that persons consuming water from the } \\
\text { supply shall not receive an effective dose equivalent } \\
\text { greater than } 4 \text { mrem per year. Combined radium- } 226 \\
\text { and radium- } 228 \text { shall not exceed } 5 \times 10^{-9} \mu \mathrm{Ci} / \mathrm{mL} \text { and } \\
\text { gross alpha activity (including radium- } 226 \text { but } \\
\text { excluding radon and uranium) shall not exceed } 1.5 \times \\
10^{-8} \mathrm{\mu Ci} / \mathrm{mL} \text {. }\end{array}$ & $\begin{array}{l}\text { Pertinent if remedial activities are "routine } \\
\text { DOE activities." } \\
\text { Pertinent if radionuclides may be releesed } \\
\text { during remediation. }\end{array}$ \\
\hline
\end{tabular}




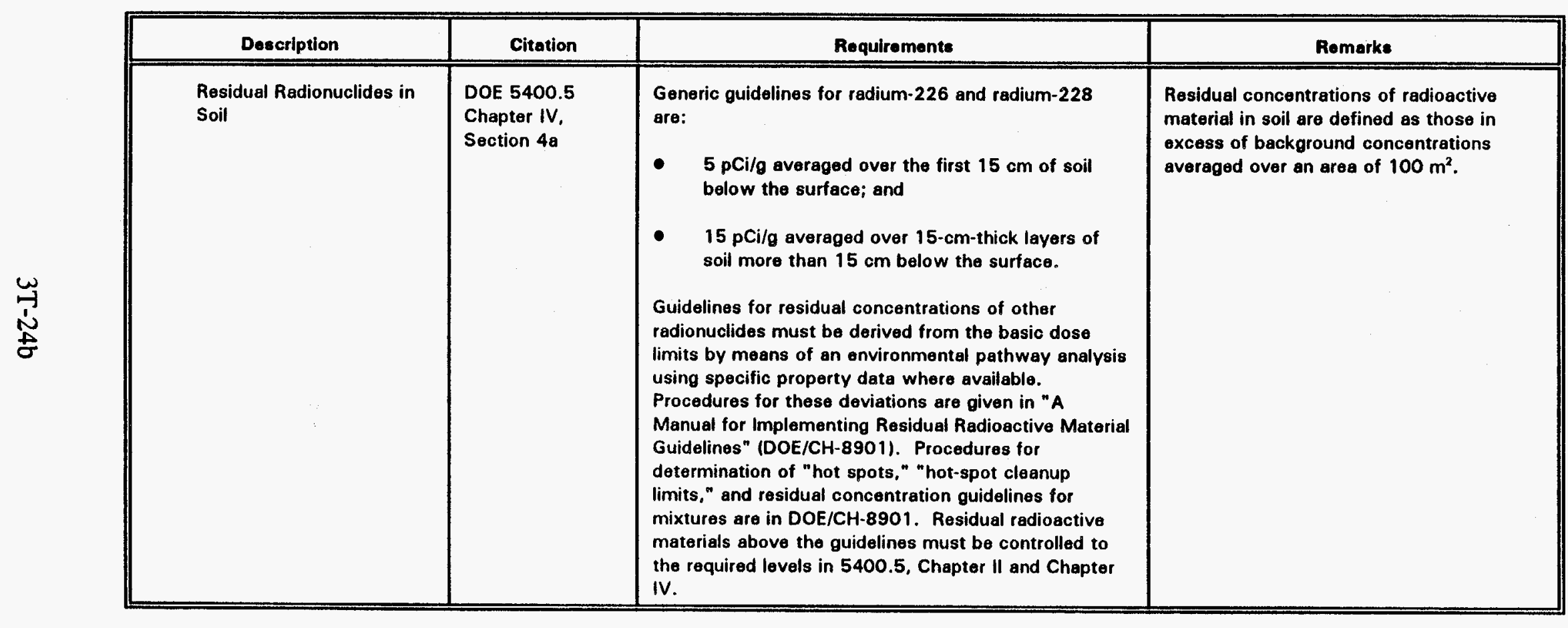




\begin{tabular}{|c|c|c|c|c|}
\hline Description & Citation & $\begin{array}{c}\text { Al } \\
\text { R\&A. }\end{array}$ & Requirements & Remarks \\
\hline $\begin{array}{l}\text { Archaoological and Historical } \\
\text { Preservation Act of } 1974\end{array}$ & 16 U.S.C. 469 & A & $\begin{array}{l}\text { Requires action to recover and preserve artifacts } \\
\text { in areas where activity may cause irreparable } \\
\text { harm, loss, or destruction of significant artifacts. }\end{array}$ & $\begin{array}{l}\text { Applicable when remedial action } \\
\text { threatens significant scientific, } \\
\text { prehistorical, historical, or archaeological } \\
\text { data. }\end{array}$ \\
\hline $\begin{array}{l}\text { Endangered Species Act of } \\
1973\end{array}$ & $\begin{array}{l}16 \text { U.S.C. } 1531 \\
\text { et seq. }\end{array}$ & & $\begin{array}{l}\text { Prohibits federal agencies from jeopardizing } \\
\text { threatened or endangered species or adversely } \\
\text { modifying habitats essential to their survival. }\end{array}$ & \\
\hline $\begin{array}{l}\text { Fish and Wildlife } \\
\text { Sorvices List of } \\
\text { Endangered and } \\
\text { Threatened Wildlife and } \\
\text { Plants }\end{array}$ & $\begin{array}{l}50 \text { CFR Parts } \\
17,222,225 \\
226,227,402 \\
424\end{array}$ & A & $\begin{array}{l}\text { Requires identification of activities that may } \\
\text { affect listed species. Actions must not threaten } \\
\text { the continued existence of a listed species or } \\
\text { destroy critical habitat. }\end{array}$ & $\begin{array}{l}\text { Requires consultation with the Fish and } \\
\text { Wildifo Service to determine if } \\
\text { threatened or ondangered species could } \\
\text { be impacted by activity. }\end{array}$ \\
\hline $\begin{array}{l}\text { Historic Sites, Buildings, and } \\
\text { Antiquities Act }\end{array}$ & 16 U.S.C. 461 & A & $\begin{array}{l}\text { Establishes requirements for preservation of } \\
\text { historic sites, buildings, or objects of national } \\
\text { significance. Undesirable impacts to such } \\
\text { resources must be mitigated. }\end{array}$ & \\
\hline Wild and Scenic Rivere Act & 16 U.S.C 1271 & A & $\begin{array}{l}\text { Prohibits federal agencies from recommending } \\
\text { euthorization of any water resource project that } \\
\text { would have a direct and adverse effect on the } \\
\text { values for which a river was designated as a } \\
\text { wild and scenic river or included as a study area. }\end{array}$ & $\begin{array}{l}\text { Tho Hanford Roach of the Columbia } \\
\text { River is under study for inclusion as a } \\
\text { wild and scenic river. }\end{array}$ \\
\hline
\end{tabular}

"NOTE: $A=$ Applicable, R\&A $=$ Relevant and Appropriate 


\begin{tabular}{|c|c|c|c|c|}
\hline Description & Citation & R\&A* & Requirements & Remarks \\
\hline \begin{tabular}{|l|}
$\begin{array}{l}\text { Habitat Buffer Zone for Bald } \\
\text { Eagie Rules } \\
\text { Bald Eagle Protection Rules }\end{array}$ \\
\end{tabular} & $\begin{array}{l}\text { RCW 77.12.655 } \\
\text { WAC 232-12-292 }\end{array}$ & A & $\begin{array}{l}\text { Prescribes action to protect bald eagle habitat, } \\
\text { such as nesting or roots sites, through the } \\
\text { development of a site management plan. }\end{array}$ & $\begin{array}{l}\text { Applicable if the areas of remedial activitics } \\
\text { includes bald eagle habitut. }\end{array}$ \\
\hline $\begin{array}{l}\text { Regulating the Taking or } \\
\text { Possessing of Game } \\
\text { Endangered, Threatened, or } \\
\text { Sensitive Wildlife Species } \\
\text { Classification }\end{array}$ & $\begin{array}{l}\text { RCW 77.12.040 } \\
\text { WAC 232-12-297 }\end{array}$ & A & $\begin{array}{l}\text { Prescribes action to protect willifife classified as } \\
\text { endengered, threatened, or sensitive, through } \\
\text { development of a site management plan. }\end{array}$ & $\begin{array}{l}\text { Applicable if wildlife classified as } \\
\text { endangered, threatened, or sensitive are } \\
\text { present in areas impacted by remedial } \\
\text { activities. }\end{array}$ \\
\hline
\end{tabular}

"NOTE: $\mathrm{A}=$ Applicable, R\&A $=$ Relevant and Appropriate 


\begin{tabular}{|c|c|c|c|}
\hline Description & Citation & Requirements & Remarks \\
\hline $\begin{array}{l}\text { Floodplains/Wetlands } \\
\text { Environmental Review }\end{array}$ & 10 CFR Part 1022 & $\begin{array}{l}\text { Requires federal agencies to avoid, to the extent possible, } \\
\text { adverse effects associated with the development of a } \\
\text { floodplain or the destruction or loss of wetlands. }\end{array}$ & $\begin{array}{l}\text { Pertinent if remedial activities take place in } \\
\text { floodplain or wellands. }\end{array}$ \\
\hline $\begin{array}{l}\text { Protection and } \\
\text { Enhancement of the } \\
\text { Cultural Environment }\end{array}$ & $\begin{array}{l}\text { Executive Order } \\
11593\end{array}$ & $\begin{array}{l}\text { Provides direction to federal agencies to preserve, restore, } \\
\text { and maintain cultural resources. }\end{array}$ & $\begin{array}{l}\text { Pertains to aites, structures, and objects of } \\
\text { historical, archeological, or architectural } \\
\text { significance. }\end{array}$ \\
\hline Hanford Reach Study Act & PL $100-605$ & $\begin{array}{l}\text { Provides for a comprehensive river conservation study. } \\
\text { Prohibits the construction of any dam, channel, or } \\
\text { navigation project by a federal agency for } 8 \text { years after } \\
\text { enactment. New federal and non-federal projects and } \\
\text { activities are required, to the extent practicable, to minimize } \\
\text { direct and adverse effects on the values for which the river } \\
\text { is under study and to utilize existing structures. }\end{array}$ & This law was enacted November 4, 1988. \\
\hline
\end{tabular}




\subsection{QUALITATIVE RISK ASSESSMENT}

This chapter provides a summary of the methods and results of the QRA that was performed for the high-priority waste sites in the 100-HR-1 Operable Unit. Complete results of the QRA are provided in Qualitative Risk Assessment for the 100-HR-I Source Operable Unit (WHC 1993a).

\subsection{QUALITATIVE RISK ASSESSMENT PROCESS}

The QRA is an evaluation of risk for a predefined set of human and ecological exposure scenarios. The QRA is not intended to replace or be a substitute for a baseline risk assessment. Consequently, the QRA is streamlined to consider only two human health scenarios (frequent and occasional usage) with four exposure pathways (soil ingestion, fugitive dust inhalation, inhalation of VOCs, and external radiation exposure) and a limited ecological evaluation. The use of these scenarios and pathways was agreed to by the 100 Area Tri-Party unit managers (December 21, 1992, and February 8, 1993). Future waste site risk estimates considering the decay of radionuclides to the year 2018, and the effect on external radiation exposure by shielding provided by current soil and gravel covers, is also presented.

\subsubsection{Approach}

The QRA is conducted using the HSBRAM (DOE-RL 1993b) as guidance and consists of:

- an evaluation of the data sources and/or process information

- identification of maximum constituent concentrations, where data are available

- a human health risk evaluation

- an ecological risk evaluation.

Key factors that contribute to uncertainty throughout the risk assessment process are also identified.

\subsubsection{Guidelines Used in the Qualitative Risk Assessment}

The following guidelines were agreed to by the Tri-Party unit managers prior to performing the QRA:

- $\quad$ Site-wide soil background concentration data are used to screen inorganic constituents.

- $\quad$ Historical radionuclide concentrations are decayed to 1992 . 
- The maximum contaminant concentration within the upper $15 \mathrm{ft}(4.6 \mathrm{~m})$ of soil, either from historical or LFI data, are used to estimate risk in the QRA.

- Two scenarios, frequent-use and occasional-use, are evaluated in the human health section of the QRA.

- For the human health exposure assessment, the pathways evaluated in the QRA. are: soil ingestion, fugitive dust inhalation, inhalation of VOCs, and external radiation exposure.

- Ecological scenarios are evaluated using the Great Basin pocket mouse because it is a key component of the Hanford area food chain and a biological endpoint with a range similar in size to the dimensions of most individual waste sites.

Several other guidelines are used in the QRA. The data collection during the LFI for the operable unit followed a known process and therefore the data are considered to be of high quality. Historical data (e.g., Dorian and Richards 1978) are considered to be of medium quality because the data were not validated and documentation was less rigorous. Where historical data do not specify $\mathrm{U}$ isotopes, $\mathrm{U}-238$ is evaluated because it represents $>99 \%$ of natural U. Chromium is assumed to be present as $\mathrm{Cr}$ (VI) because it provides the most conservative evaluation and $\mathrm{Cr}$ was not speciated during analysis. Nickel in the soil environment is not considered carcinogenic because the pyrolytic activity which generates the carcinogenic form of Ni was not present in the operable unit. If toxicity factors are not available for a constituent, surrogate factors are generally not used, unless specifically noted.

The qualitative risk estimations are grouped into high (incremental cancer risk [ICR] $>$ 1E-02), medium ( $1 \mathrm{E}-04<\mathrm{ICR}<1 \mathrm{E}-02)$, low $(1 \mathrm{E}-06<\mathrm{ICR}<1 \mathrm{E}-04)$, and very low $(\mathrm{ICR}<1 \mathrm{E}-06)$ risk categories. A frequent-use scenario is evaluated in the year 2018 to ascertain potential future risks associated with each waste site after additional radionuclide decay. For the current occasional-use scenario, the effect of radiation shielding by the upper $6 \mathrm{ft}(2 \mathrm{~m})$ of soil on the external exposure risk at each waste site is evaluated.

For the ecological risk assessment, metals are assumed to be bioavailable for uptake by vegetation. The identified concentrations are assumed to be uniformly distributed over the site, biologically active, and available for transport. Hazard quotients (HQ) for ecological exposure to radionuclides are based on an exposure limit of $1 \mathrm{rad} / \mathrm{day}$ (DOE Order 5400.5 ) and the lowest observable effect level (LOEL) dose.

\subsection{HUMAN HEALTH QUALITATIVE RISK ASSESSMENT}

The QRA provides estimates of risk that might occur under frequent-use or occasional-use scenarios based on the best available knowledge of current contaminant conditions, but does not represent actual risks since neither frequent-use nor occasional-use of high-priority sites currently occurs. 


\subsubsection{Overview of the Human Health Risk Evaluation Process}

The frequent-use and occasional-use scenarios are evaluated using residential and recreational exposure parameters from HSBRAM (DOE-RL 1993b), respectively. The frequent-use scenario is addressed for current (1992) and future (2018) contaminant concentrations. Air inhalation of VOCs is eliminated from this analysis because VOCs are not present above preliminary risk-based screening levels in the soil at any waste site. Therefore, inhalation of VOCs is not a likely exposure pathway for this operable unit. For the soil ingestion and external exposure pathways, maximum sample concentrations from the upper $15 \mathrm{ft}(4.6 \mathrm{~m})$ of soil are used. For the fugitive dust inhalation pathway, maximum contaminant concentrations in the upper $15 \mathrm{ft}(4.6 \mathrm{~m})$ of soil are used in conjunction with a particulate emission factor. This factor relates contaminant concentrations in the soil to concentrations of respirable particles in the air due to fugitive dust emissions. Quantification of exposures is conducted using Section 2.3 of HSBRAM (DOE-RL 1993b).

The external exposure pathway is also evaluated for the current occasional-use scenario while considering the effect of shieiding by existing soil cover. In this evaluation, only radionuclides detected in the upper $6 \mathrm{ft}(2 \mathrm{~m})$ of soil are considered as contributors to external radiation exposure. These external exposure risks are considered to be more representative of current site conditions where activities in a contaminated zone are controlled.

Section 2.3 of the HSBRAM (DOE-RL 1993b) contains the general procedures followed in the QRA for toxicity assessment. The toxicity assessment in the QRA involves the selection of slope factors and reference doses for COPC and includes sufficient toxicity information on COPC to assist project managers in reaching decisions on IRMs.

Risk characterization for the individual waste sites differs depending on the type and amount of data available for the specific waste site. Risk characterization is conducted in accordance with Section 2.4 of HSBRAM (DOE-RL 1993b). The risk characterization for each site is performed by calculating contaminant-specific ICRs and HQs and then summing contaminant-specific risks to obtain a risk estimate for the waste site.

For sites where sampling data are not available to calculate ICRs and HQs, the risk characterization consists of a qualitative discussion of the site, the potential threat posed by the site, and the confidence in the information available to assess the threat. Risk estimates from analogous sites are used, where appropriate, to qualitatively determine possible contaminants and potential risk levels. The basic intake equations presented in Appendix $\mathrm{C}$ of the 100-HR-1 QRA (WHC 1993a) are modified to identify soil contaminant concentrations associated with an ICR of 1E-06 or an HQ of 1, using HSBRAM (DOE-RL 1993b) exposure parameters. 


\subsubsection{Results of the Human Health QRA}

An overview of the human health QRA, and associated uncertainties, for the 100-HR-1 QRA are summarized in the following sections. includes:

Information summarized in Tables 4-1, 4-2 and 4-3 for the human health QRA

- data availability and confidence in data

$\because \quad$ the qualitative risk estimation

- the risk-driving contaminants for the frequent-use and occasional-use scenarios

- the risk-driving pathways for the frequent- and occasional-use scenarios.

The risk-driving contaminants for both the frequent- and occasional-use scenarios are generally radionuclides and the primary risk-driving pathway is usually the external exposure pathway.

The high-priority waste sites listed in Table 4-2 of the 100-HR-1 Work Plan (DOE 1992a) are evaluated in the QRA. Where LFI data were not collected, historical data were used in the risk assessment. Where sampling data were not available, risk estimates from analogous waste sites (if any) were considered in evaluating the potential risk from the waste site.

Based on the QRA, the high-priority waste sites within the 100-HR-1 Operable Unit are grouped into high, medium, low, and very low risk categories as shown in Table 4-3. The results of the frequent-use scenario are summarized as follows:

- The waste site(s) considered high risk for the frequent-use scenario are the 116-H-1 trench $(1992,2018), 116-\mathrm{H}-3$ french drain (1992), 116- $\mathrm{H}-7$ retention basin $(1992,2018)$, and process effluent pipelines (sludge) $(1992,2018)$.

- The waste site(s) considered medium risk for the frequent-use scenario are the 116-H-2 trench $(1992,2018), 116-\mathrm{H}-3$ french drain (2018), and 116-H-9 crib $(1992,2018)$. The medium risk for the $116-\mathrm{H}-9$ crib was calculated using highly questionable data; the sum of inorganic constituents was greater than one half the mass of the sample.

- The waste site(s) considered low risk for the frequent-use scenario are the process effluent pipelines (soil) $(1992,2018)$ and 116-H-7 sludge burial trench (1992).

- The waste site(s) considered very low risk for the frequent-use scenario is the 116- $\mathrm{H}-7$ sludge burial trench (2018). 
The results of the occasional-use scenario are summarized as follows:

- The waste site(s) considered high risk for the occasional-use scenario are the 116-H-7 retention basin and process effluent pipelines (sludge). The risk-driving radionuclides at the process effluent pipelines (sludge) waste site are not present in the upper $6 \mathrm{ft}(2 \mathrm{~m})$ of soil.

- The waste site(s) considered medium risk for the occasional-use scenario is the 116-H-1 trench.

- The waste site(s) considered low risk for the occasional-use scenario are the 116- $\mathrm{H}-2$ trench, 116-H-3 french drain, and 116-H-9 crib.

- The waste site(s) considered very low risk for the occasional-use scenario are the process effluent pipelines (soil) and 116- $\mathrm{H}-7$ sludge burial trench.

Other results of the QRA as presented in Tables 4-2 and 4-3 are:

- $\quad$ Radionuclides are identified as the primary contributors to the overall risks via the external exposure pathway. The specific radionuclides identified as key contributors are Co-60, Cs-137, Eu-152, and Eu-154.

- There are several sites where potential contaminants are identified only on the basis of historical information and no contaminant concentrations are known. These sites include the 116-H-5 outfall structure, 132- $\mathrm{H}-3$ pump station, 116-H-6 retention basin, 132- $\mathrm{H}-2$ building, 132- $\mathrm{H}-1$ stack, and 116-H-4 crib. Concentrations at which an ICR of 1E-06 or an HQ of 1.0 would exist are calculated for the potential contaminants. Estimated risks are considered qualitative estimates (qualitative risk rating) and are based on suspected risk-driving contaminants, disposal information, and the size of the waste site.

The risks, both carcinogenic and non-carcinogenic, presented in this QRA are deterministic estimates given multiple assumptions about exposure, toxicity, and variables. Consequently, uncertainty exists for the evaluation of the contaminants, the exposures, the toxicities, and the risk characterization for the QRA. This uncertainty is discussed more extensively in the following sections.

\subsubsection{Summary of Key Uncertainties in the Human Health Risk Assessment}

In general, the QRA is based on a limited data set. Uncertainties are associated with both the contaminants identified for each waste site and the concentrations of the contaminants. Collected samples may not be representative of conditions throughout the waste site and historical data may not accurately represent current conditions. Because the samples may not be completely representative of the site, risks may be underestimated or overestimated. 
Uncertainty exists with respect to the identification of specific contaminants. Where the isotope of uranium is not specified uranium is evaluated as U-238. The slope factors for the various uranium isotopes differ slightly from one another, resulting in slightly different risks if each is evaluated separately. The valence state of $\mathrm{Cr}$ identified in the QRA samples was not known. For the risk estimate, the most toxic form was assumed (Cr VI). However, risks are overestimated if $\mathrm{Cr}$ exists as the less toxic form ( $\mathrm{Cr}$ III).

External exposure slope factors are appropriate for a uniform contaminant distribution, infinite in depth and areal extent (i.e., an infinite slab source), with no clean soil cover. For high-energy gamma emitters (e.g., Co-60 and Cs-137), the assumption of an infinite slab source can only be satisfied if these radionuclides extend to nearly $6 \mathrm{ft}(2 \mathrm{~m})$ bgs, and over a distance of a few hundred meters or more. If the site being evaluated is smaller than this, or if the site has a clean soil cover, then use of external exposure slope factors is likely to provide risk estimates that may be unrealistic. The fact that the external exposure pathway is the risk-driver at many waste sites is not surprising and in some cases may be indicative of the conservatism built into the evaluation of this pathway rather than the actual associated risk.

There is uncertainty associated with the toxicity information available to assess potential adverse effects. The interpretation of the toxicity data and the actual toxicity values used for the QRA are both sources of uncertainty. These uncertainties contribute to the uncertainty in the risk assessment.

When there is a high degree of uncertainty associated with the information used to determine toxicity, there is less confidence in the assessment of the risk associated with exposure. The primary sources of these uncertainties include the following:

- use of information on dose-response effects from high-dose exposure scenarios to predict effect at low-dose exposure scenarios.

- use of animal dose-response data to predict effects in humans.

- use of short-term exposure data to extrapolate to long-term exposure, or vice versa.

- use of dose-response information from a homogeneous animal or healthy human population to predict the effects that may occur in the general population where there are varying sensitivities to different contaminants.

Uncertainty in the risk characterization also results from summing ICRs and HQs across contaminants and pathways, a process which gives equal weight to toxicity information derived from different sources or species. Exposures to multiple contaminants may result in additive effects or effects that are greater or less than additive.

Historical information and risk estimates from analogous sites may be used to evaluate some of the high-priority waste sites. The selection of analogous sites for the QRA is based 
on available information at the time the QRA was prepared. As additional information is identified and incorporated into the LFI report for an operable unit, the QRA should be updated to utilize additional pertinent information.

\subsection{ECOLOGICAL QUALITATIVE RISK ASSESSMENT}

The purpose of the qualitative ecological risk assessment is to estimate the ecological risks from existing contaminant concentrations in the 100-HR-1 Operable Unit to selected ecological receptors.

The 100-HR-1 Operable Unit is a terrestrial waste unit. The approach, consistent with the objective of the QRA, is to assess the dose to the Great Basin pocket mouse which is the indicator ecological receptor of risk from each of the waste sites within the 100-HR-1 Operable Unit. The mouse is used as the indicator receptor because its home range is comparable to the size of most waste sites and will receive most of its dose from a waste site. This allows a risk comparison between waste sites.

Ecological Effects. Contaminants found in the soil at waste sites within the 100-HR-1 Operable Unit include radioactive and non-radioactive elements. For non-radioactive elements, ecological effects were evaluated from uptake from the soil by plants, and by accumulation of these elements through the foodweb. Radioactive elements have ecological effects resulting from their presence in the abiotic environment (external dose), and from ingestion (e.g., dose from contaminated food consumption), resulting in a total body burden. Total daily doses to an organism can be estimated as the sum of doses (weighted by energy of radiation) received from all radioactive elements ingested, residing in the body, and available in the organism's environment. Radiological dose calculation methodology as reviewed by Baker and Soldat (1992), were applied in this QRA.

The radiological dose an organism receives is usually expressed as rad/day. Exposure can resuit from both external environmental radiation and internal radiation from body burden. All exposure pathways are added in determining total organism dose. Internal exposure includes both body burden (contaminants that are taken into the body from all pathways) and dose from recent food consumption which is still in the gut.

Endpoint Selection. The assessment and measurement endpoint is the health and mortality of the Great Basin pocket mouse, respectively. This is consistent with the objective of the qualitative ecological risk assessment. The dose to the pocket mouse was used to screen the level of risk of an individual waste site. For radionuclides, mouse dose is compared to $1 \mathrm{rad} /$ day (DOE Order 5400.5) (IAEA 1992). For non-radiological contaminants, the dose is compared to toxicity values.

Risk is evaluated for the Great Basin pocket mouse based on a two-step accumulation model operated on a waste-site-by-waste-site basis, since each waste site approximates the size of the Great Basin pocket mouse home range. The method of integration is based on 
averaging waste site constituent concentrations over the operable unit as a fraction of the total operable unit area.

Exposure Analysis. The purpose of the exposure analysis is to integrate the spatial and temporal distributions of the ecological components and stressors to evaluate exposure.

All non-radioactive and radioactive constituents identified as of potential concern in the human health risk assessment (before the screening of constituents with the greatest human health risk) were considered to be of concern in the ecological risk assessment. Because of the lack of site-specific data other than soil, it was assumed the receptor spends some fraction of its life in the site, obtains all its food from the site when present, and all consumed food is contaminated. However, because there is no source of water within the site, drinking water was not considered a route of exposure.

For non-radiological constituents, concentrations estimated in mice were compared to the reported benchmark or potentially toxic concentrations. For radiological constituents, mice concentrations were converted to dose. Total dose for all radionuclides are compared to published effect leveis and regulatory standards where available.

Exposure Profile. The ecological risk assessment focuses on potential noncarcinogenic effects on the Great Basin pocket mouse potentially exposed to constituents present in the 100-HR-1 Operable Unit waste sites. Terrestrial vegetation is represented as a generic plant species for uptake from the soil and as a food source for mice.

The major route of contaminants to plants is assumed to be direct uptake from soil. Ingestion of vegetation is assumed to be a major route of exposure to the mouse and ingestion of mice and insects is the major route for the shrike, for both non-radiological and radiological constituents. For radionuclides, the exposure pathway considered uptake from contaminated food resulting in internal exposure. For both radiological and non-radiological contaminants, the dose is based on receptor whole-body concentrations. Metals stressors are assumed to be bioavailable for uptake by vegetation, which is consistent with the objectives of the QRA.

\subsubsection{Results of the Ecological Evaluation}

A qualitative ecological risk assessment was completed for the 100-HR-1 Operable Unit. Site 116- $\mathrm{H}-1$ trench, 116- $\mathrm{H}-2$ trench, 116- $\mathrm{H}-7$ retention basin, process effluent pipelines (sludge) exceeded the $1 \mathrm{rad} /$ day with an environmental hazard quotient (EHQ) $>1$ (Table 4-4). For sites that exceeded the radionuclide $1 \mathrm{rad} /$ day benchmarl, all of the dose is from $\mathrm{Sr}-90$.

Routine surveying of surface soil contamination in the $116-\mathrm{H}-1,116-\mathrm{H}-2$, and 116- $\mathrm{H}-7$ sites showed beta levels which indicated surface contamination. For non-radiological constituents, site 116- $\mathrm{H}-1$ trench exceeded the no observable effect level (NOEL) for As, however the concentration used in the risk characterization is from the 
0-15 ft soil interval. The NOELs for $\mathrm{As}, \mathrm{Pb}$ and $\mathrm{Zn}$ are exceeded at site 116-H-7. Waste site 116-H-9 crib exceeded NOELs for $\mathrm{Ba}, \mathrm{Mn}$ and $\mathrm{V}$ (Table 4-5).

The estimated dose from Sr-90 to the Great Basin pocket mouse exceeded $1 \mathrm{rad} /$ day from all waste sites that had measurable Sr-90 at the 100-HR-1 Operable Unit (Table 4-4 of the QRA). This extremely high calculated dose is believed to be an artifact of the modeling parameters (e.g., source term) and does not reflect actual conditions. The significance of dose estimates, either radiological or hazardous chemicals, as the risk driver is governed by the accuracy of the source terms. If the source of Sr-90 is $6-15 \mathrm{ft}$ below the surface, the dose may not represent real ecological risk since the exposure scenario is unrealistic. The approach in the QRA is to use the maximum level of contamination irrespective of depth (anywhere from 0-15 ft depth) which drives the QRA far into the conservative side and makes the results useful only for comparison between waste sites.

\subsubsection{Summary of Key Uncertainties in the Ecological Evaluation}

The uncertainty in contaminant concentrations for the ecological evaluation is related to the accuracy of the data. For the QRA, uncertainty exists in both contaminants identified and exposure concentrations. As for the human health assessment, the maximum contaminant concentration was used.

The QRA models the potential exposure of wildlife suspected to actually be present in or near the waste site. The issues of concern with regard to ecological risk assessment (particularly qualitative) are the uncertainties in using an assortment of environmental variables in risk modeling. This begins with the source term. If this number is not realistic, no amount of modeling will overcome this deficiency. For example, in the case of the QRAs, the maximum reported waste concentration was used as the source term no matter how deep this concentration.

Generally, site specific organisms (e.g., pocket mouse), are identified as being associated with a site, but little if any data may exist concerning transfer of contaminants to site specific organisms. Often, it is necessary to use biological trophic transfer information for related species.

A significant source of uncertainty in the exposure scenario is that the waste site is uniformly contaminated and in the case of the mouse, all food is assumed to be contaminated. No provision is made for dilution of contaminated food by non-contaminated food. It was also assumed contaminants were not passed through the gut, but completely retained (100\% absorption efficiency).

To complete the QRA for the 100-HR-1 Operable Unit it was necessary to use data from surrogate organisms in place of the pocket mouse since no site data are available for this organism. This contributes to overall QRA uncertainty. In addition, transfer coefficients used to model uptake of contaminants from soil to plants were not Hanford specific, the approach did not consider whether roots of a plant actually grow deep enough to 
contact a contaminant, and the model did not account for reduced concentrations from plant to seed (it was assumed the seed concentration was the same as the plant). The pocket mouse food consumption rate was generalized and seasonal behavior (hibernation) that would reduce exposure and body burden was not considered.

Uncertainty associated with wildlife toxicity values is significant, particularly for non-radiological contaminants. The approach used in the QRA tends to build conservatism into the toxicity value. 
Table 4-1 Summary of Data Availability and Data Confidence (for sites where data are available)

\begin{tabular}{|c|c|c|c|c|c|}
\hline \multirow[t]{2}{*}{ Waste Site } & \multicolumn{5}{|c|}{ Summary of Data Availability and Data Confidence } \\
\hline & $\begin{array}{c}\text { Historical } \\
\text { Data }^{\mathrm{a}}\end{array}$ & $\begin{array}{l}\text { LFI } \\
\text { Data }^{a}\end{array}$ & $\begin{array}{l}\text { Data from } \\
\text { the same } \\
\text { Medium }\end{array}$ & $\begin{array}{l}\text { Confidence in } \\
\text { Contaminant } \\
\text { Identification }\end{array}$ & $\begin{array}{l}\text { Confidence in } \\
\text { Contaminant } \\
\text { Concentrations }\end{array}$ \\
\hline \multicolumn{6}{|c|}{ Sites with LFI data and historical data } \\
\hline 116- $\mathrm{H}-1$ trench & $\mathbf{R}$ & $R, I, 0$ & Yes & high & medium \\
\hline 116- $\mathrm{H}-2$ trench & $\mathbf{R}$ & $R, 1,0$ & Yes & medium & medium \\
\hline $\begin{array}{l}\text { 116-H-3 french } \\
\text { drain }\end{array}$ & $\mathbf{R}$ & $R, 1,0$ & Yes & high to med. & medium \\
\hline $\begin{array}{l}116-H-7 \text { retention } \\
\text { basin }\end{array}$ & R & $R, I, 0$ & No & high & low \\
\hline 116-H-9 crib & - & $R, 1,0$ & - & high & high \\
\hline \multicolumn{6}{|c|}{ Sites with historical data only } \\
\hline $\begin{array}{l}\text { Process Effluent } \\
\text { Pipelines }\end{array}$ & $R$ & - & - & medium & low \\
\hline $\begin{array}{l}116-\mathrm{H}-7 \text { sludge } \\
\text { burial trench }\end{array}$ & $\mathbf{R}$ & - & - & med. to low & low \\
\hline \multicolumn{6}{|c|}{$\begin{array}{l}=\text { Not applicable } \\
{ }^{2} R=\text { radionuclide, } I=\text { inorganic, } O=\text { organic contaminant } \\
\text { LFl and Historical Data are from the same medium (e.g., both from soil) or from different } \\
\text { media (e.g., soil and sludge) }\end{array}$} \\
\hline
\end{tabular}




\begin{tabular}{|c|c|c|c|c|c|}
\hline Site & Disposal Information & $\begin{array}{l}\text { Suspected } \\
\text { Risk-Driving } \\
\text { Contaminants }\end{array}$ & $\begin{array}{l}\text { Description } \\
\text { and Notes }\end{array}$ & $\begin{array}{l}\text { Qualitative } \\
\text { Risk } \\
\text { Rating" }\end{array}$ & Rationale for Rating \\
\hline $\begin{array}{l}116-\mathrm{H}-5 \\
\text { outfall } \\
\text { structure }\end{array}$ & $\begin{array}{l}\text { Unknown volume of treated process } \\
\text { effluent from the } 116-\mathrm{H}-7 \text { retention } \\
\text { basin between } 1949 \text { and } 1965 \text {. }\end{array}$ & $\begin{array}{l}\text { Co-60, Eu-152, Eu-154, } \\
\text { As }\end{array}$ & $\begin{array}{l}\text { Compartmented concrete box } \\
\text { measuring } 378 \times 27 \times 14 \mathrm{ft} \text {. }\end{array}$ & medium & $\begin{array}{l}116-D-5 \text { outfall structure } \\
\text { in the 100-DR-1 operable } \\
\text { unit has a high risk } \\
\text { estimate. }\end{array}$ \\
\hline $\begin{array}{l}\text { 132-H-3 pump } \\
\text { station }\end{array}$ & $\begin{array}{l}\text { Pumped water from } H \text { reactor drains } \\
\text { from } 1949 \text { to } 1965 \text {. Sump water } \\
\text { and sludge removed in } 1987 .\end{array}$ & $\begin{array}{l}\text { Co-60, Cs-134, Ra-226, } \\
\text { Th-228, As, Hg }\end{array}$ & $\begin{array}{l}\text { Demolished and buried in-situ in } \\
1987 \text {. Backfilled with a } \\
\text { minimum of } 15 \mathrm{ft} \text { of clean fill. }\end{array}$ & low & $\begin{array}{l}\text { Building rubble buried } \\
\text { under } 15 \mathrm{ft} \text { of fill. }\end{array}$ \\
\hline $\begin{array}{l}116-H-6 \\
\text { retention basin }\end{array}$ & $\begin{array}{l}\text { Received fuel fabrication wastes from } \\
\text { the } N \text { reactor, treated wastes by } \\
\text { solar evaporation. Received wastes } \\
\text { through } 1985 \text {. }\end{array}$ & $\begin{array}{l}\text { uranium, } \mathrm{P}, \text { thallium } \\
\text { oxide, } \mathrm{As}, \mathrm{Hg}, \mathrm{Sb}, \mathrm{Be}\end{array}$ & $\begin{array}{l}\text { Four concrete basins measuring } \\
45 \times 33 \times 10 \mathrm{ft} \text {. } \\
\text { Decommissioned in } 1991 .\end{array}$ & medium & $\begin{array}{l}\text { Possible effluent leakage; } \\
\text { high volume of liquid } \\
\text { waste received. }\end{array}$ \\
\hline $\begin{array}{l}132-\mathrm{H}-2 \\
\text { building }\end{array}$ & $\begin{array}{l}\text { Filtered reactor exhaust air prior to } \\
\text { emission using high-efficiency } \\
\text { particulate air and halogen filters. }\end{array}$ & $\begin{array}{l}\text { Co-60, Sr-90, Cs-137. } \\
\text { Eu-152, Eu-154 }\end{array}$ & $\begin{array}{l}59 \times 39 \times 35 \mathrm{ft} \text {. concrete } \\
\text { building. } 90 \% \text { below ground. } \\
\text { Demolished and buried in-situ in } \\
1983 \text { and covered with } 3 \mathrm{ft} \text { of } \\
\text { soil. }\end{array}$ & low & $\begin{array}{l}\text { Building rubble buried } \\
\text { under } 3 \mathrm{ft} \text {. of fill; filters } \\
\text { removed. }\end{array}$ \\
\hline 132-H-1 stack & $\begin{array}{l}\text { Emitted filtered air from the } 132-\mathrm{H}-2 \\
\text { building. Documented radionuclide } \\
\text { release in } 1955 \text {. }\end{array}$ & $\begin{array}{l}\text { Co-60, Sr-90, Cs-137. } \\
\text { Eu- } 152\end{array}$ & $\begin{array}{l}200 \times 16 \mathrm{ft} \text { concrete stack. } \\
\text { demolished in } 1983 \text { and covered } \\
\text { with } 3 \mathrm{ft} \text { of soil. }\end{array}$ & low & $\begin{array}{l}\text { Building rubble buried } \\
\text { under } 3 \mathrm{ft} \text { of soil. }\end{array}$ \\
\hline 116-H-4 crib & $\begin{array}{l}\text { Received low volumes of cooling } \\
\text { water during periods of fuel element } \\
\text { failure; discharged waste from fuel } \\
\text { element failure. }\end{array}$ & $\begin{array}{l}\text { (See } 132-\mathrm{H}-2 \text { building } \\
\text { evaluation) }\end{array}$ & $\begin{array}{l}4 \times 4 \times 2 \mathrm{ft} \text { crib used from } 1950 \\
\text { to } 1952 \text {. Excavated in } 1960 \text { to } \\
\text { a depth of } 30 \mathrm{ft} \text { for construction } \\
\text { of } 132-\mathrm{H}-2 \text { building on same site. }\end{array}$ & $\begin{array}{l}\quad \text { low } \\
\text { (See 132-H-2 } \\
\text { building evaluation) }\end{array}$ & $\begin{array}{l}\text { Crib was in service only } \\
\text { two years, has been } \\
\text { excavated to } 30 \mathrm{ft} \\
\text { depth. }\end{array}$ \\
\hline
\end{tabular}

- Rating is qualitative based on process information, analogous site information, and site-specific information such as size, potential contaminants, and location of contamination as indicated under rationale column. Additional discussion on the rating is provided for each site in the 100-HR-1 QRA (WHC 1993a). 
DOE/RL-93-51, Rev. 0

\section{Table 4-3 Human Health Risk Assessment Summary (for sites where data are available).}

\begin{tabular}{|c|c|c|c|c|c|}
\hline \multirow[t]{4}{*}{ Waste Site } & \multicolumn{5}{|c|}{ Human Health Risk Assessment Summary } \\
\hline & \multicolumn{3}{|c|}{ Frequent-Use Scenario } & \multicolumn{2}{|c|}{ Occasional-Use Scenario } \\
\hline & \multicolumn{2}{|c|}{$\begin{array}{l}\text { Qualitative Risk } \\
\text { Estimation }\end{array}$} & \multirow{2}{*}{$\begin{array}{l}\text { Risk Driving } \\
\text { Contaminant } \\
\text { (and pathway }{ }^{b} \text { ) }\end{array}$} & \multirow{2}{*}{$\begin{array}{l}\text { Qualitative } \\
\text { Risk } \\
\text { Estimation } \\
\text { (1992) }\end{array}$} & \multirow{2}{*}{$\begin{array}{l}\text { Risk Driving } \\
\text { Contaminant } \\
\text { (and pathway }{ }^{b} \text { ) }\end{array}$} \\
\hline & 1992 & 2018 & & & \\
\hline \multicolumn{6}{|c|}{ Sites with LFI and historical data } \\
\hline 116-H-1 trench & high & high & $\begin{array}{c}\mathrm{R}(\mathrm{O}, \mathrm{I}, \mathrm{E})^{\mathrm{c}} \mathrm{I}(\mathrm{O}, \mathrm{I}) \\
\mathrm{O}(\mathrm{I})\end{array}$ & medium & $R(E), I(O)$ \\
\hline 116-H-2 trench & medium & medium & $\mathrm{R}(\mathrm{O}, \mathrm{I}, \mathrm{E})$ & low & $R(E)$ \\
\hline 116-H-3 french drain & high & medium & $R(O, I, E)$ & low & $\mathbf{R}^{d}(E)$ \\
\hline 116-H-7 retention basin & high & high & $\mathrm{R}(\mathrm{O}, \mathrm{I}, \mathrm{E}) \mathrm{I}(\mathrm{O}, \mathrm{I})$ & medium & $\mathrm{R}(\mathrm{O}, \mathrm{I}, \mathrm{E}) \mathrm{I}(\mathrm{O})$ \\
\hline 116-H-9 crib & medium & medium & $\mathrm{R}(\mathrm{I}, \mathrm{E})^{\mathrm{e}} \mathrm{I}(\mathrm{O}, \mathrm{I})$ & low & $R(E) I$ \\
\hline \multicolumn{6}{|l|}{ Sites with historical data only } \\
\hline $\begin{array}{l}\text { process effluent pipelines } \\
\text { (soil) }\end{array}$ & low & low & $\mathbf{R}^{\mathrm{de}}(\mathrm{E})$ & very low & - \\
\hline $\begin{array}{l}\text { process effluent pipelines } \\
\text { (sludge) }\end{array}$ & high & high & $\mathrm{R}^{\mathrm{e}}(\mathrm{O}, \mathrm{I}, \mathrm{E})$ & high & $\mathrm{R}^{\mathrm{e}}(\mathrm{O}, \mathrm{I}, \mathrm{E})$ \\
\hline $\begin{array}{l}\text { 116-H-7 sludge burial } \\
\text { trench }\end{array}$ & low & very low & $\mathbf{R}^{\text {def }}(\mathrm{E})$ & very low & - \\
\hline \multicolumn{6}{|c|}{$\begin{array}{l}=\text { Not applicable } \\
{ }^{2} R=\text { radionuclide, } I=\text { inorganic, } O=\text { organic contaminant } \\
O=\text { oral, } I=\text { inhalation, } E=\text { external exposure pathways. } \\
\text { Only the external exposure pathway has the risk driving contaminants for } 2018 \text {. } \\
\text { d Radionuclides contributing }>1 E-06 \text { to the risk have half-lives of } 30 \text { years or less. } \\
\text { e Radionuclide concentrations analyzed and detected in upper } 6 \mathrm{ft}(2 \mathrm{~m}) \text { did not exceed ICR of } 1 E-06 \\
\text { (see Appendix F in WHC 1993b). }\end{array}$} \\
\hline
\end{tabular}


DOE/RL-93-51, Rev. 0

Table 4-4 Environmental Hazard Quotients Summary for Radionuclides by Waste Site

\begin{tabular}{|l|c|}
\hline \multicolumn{1}{|c|}{ Waste Site } & $\begin{array}{c}\text { Dose Rate } \\
\text { Exceeds EHQ of 1 }\end{array}$ \\
\hline 116-H-1 Trench & yes \\
\hline 116-H-2 Trench & yes \\
\hline 116-H-3 Drain & no \\
\hline 116-H-7 Retention Basin & yes \\
\hline 116-H-9 Crib & no \\
\hline Process Effluent Pipelines (Soil) & no \\
\hline Process Effluent Pipelines (sludge) & yes \\
\hline
\end{tabular}




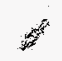

DOE/RL-93-51, Rev. 0

Table 4-5 Environmental Hazard Quotient Summary for Non-radiological Contaminants by Waste Site

\begin{tabular}{|l|l|}
\hline \multicolumn{1}{|c|}{ Contaminant } & Dose Rate Exceeds EHQ of 1 \\
\hline $116-\mathrm{H}-1$ Trench & yes-arsenic \\
\hline $116-\mathrm{H}-7$ Retention Basin & yes-arsenic, lead, zinc \\
\hline $116-\mathrm{H}-9$ Crib & $\begin{array}{l}\text { yes-barium, manganese, } \\
\text { vanadium }\end{array}$ \\
\hline
\end{tabular}




\subsection{RECOMMENDATIONS}

The primary purpose of the LFI report is to recommend those high-priority sites that should remain candidates on the IRM path and those high-priority sites which should not remain candidates for the IRM path. Sites that are not recommended as candidates for an IRM will be addressed in the final remedy selection process. These recommendations are generally independent of future land-use scenarios.

\subsection{GENERAL CONSIDERATIONS}

Analysis of LFI samples from the high-priority sites did not detect any pesticide or PCB compounds and only three VOCs were found. The VOCs are most likely the result of contamination from analytical procedures used in the off-site analytical laboratories. The detected semi-volatile compounds were PNAs which are typical constituents in coal tars and creosote. The source of this contamination is likely creosote treated timbers and pipes. Timbers were used to construct the cribs and the wood baffles in the retention basins. Contamination by metals was found at the $116-\mathrm{H}-7$ retention basin and the 116- $\mathrm{H}-1$ trench. Radionuclide contamination was detected at both these sites and at the 116-H-3 drain where a very small concentration of Eu-152 was detected. Radionuclide contamination was detected at all five sites investigated during the LFI. The 116- $\mathrm{H}-7$ retention basin and the 116-H-1 trench had the highest detected concentrations of man-made radionuclides. The other three sites (116-H-2 trench, 116- $\mathrm{H}-3$ drain, and 116-H-9 crib) had small concentrations, $<2 \mathrm{pCi} / \mathrm{g}$, of radionuclide contaminants.

The historical data (Dorian and Richards 1978) were found to be generally reliable in predicting the probability of radionuclide contamination but unreliable in predicting the levels of contamination. The historical analytical results were consistently found to indicate levels of radionuclide contamination one to three orders of magnitude higher than the LFI data. The cause of this disparity is unclear but may be due to differences in analytical instrumentation accuracy or sampling locations.

None of the sites pose an imminent threat to human health or the environment, or pose risks sufficient to warrant an ERA. The evaluation of sites is presented in the following sections.

\subsection{HIGH-PRIORITY SITE IRM CANDIDATE EVALUATION CRITERIA}

The 100-HR-1 high-priority sites were evaluated using the following criteria to identify those sites where continuing the IRM pathway is recommended:

- an assessment of the adequacy of the waste site conceptual model

- identification of any ARAR exceedance for vadose zone contaminants 
- $\quad$ the 100-HR-1 QRA (WHC 1993a)

- an evaluation of site-specific contaminant impact on groundwater

- identification of sites where natural attenuation by the year 2018 may mitigate contamination.

\subsubsection{Conceptual Model}

The conceptual model for the waste site includes sources of contamination, types of contaminants, nature and extent of contamination in each affected media, known and potential routes of migration, known or potential human and environmental receptors, and the general understanding of the site structure/process. This information is included in Chapter 3 of the 100-HR-1 Work Plan (DOE-RL 1992a) and has been revised using data obtained during the LFI. Table 5-1 presents sources of contamination, COPC, nature and extent of contamination in each affected media, and the general understanding of the structure/process for each high-priority waste site. Figure 5-1 presents the known and potential routes of migration, known or potential human and environmental receptors for the operable unit. If the conceptual model of a site is incomplete the site is recommended to remain as an IRM candidate while the data needed to complete the model are collected. After the data are available the site will be reevaluated for continued candidacy for an IRM. The additional data may be obtained through limited field sampling.

\subsubsection{Applicable or Relevant and Appropriate Requirements}

The Washington State MTCA Method B concentrations are potential ARARs for soil contamination, as discussed in Section 3.9 of this report and in the 100 Area Feasibility Study, Phases 1 and 2 (DOE-RL 1992c). Model Toxics Control Act Method B regulatory limits for soil contaminant concentrations are utilized since they are the standard approach and are conservative. Table 5-2 lists the Hanford Site background 95\% UTL values for metallic constituents in soils and MTCA Method B guidelines for soil. Sites that have concentrations of contaminants which exceed this potential chemical-specific ARAR are recommended to continue as IRM candidates.

\subsubsection{Qualitative Risk Assessment}

The QRA provides risk estimates for human health and for adverse ecological effects. Human health risks, specifically ICR, for the high-priority sites were developed in the QRA using two scenarios: frequent-use and occasional-use . The occasional-use risk values are used to evaluate the continued candidacy of high-priority sites for IRMs. The qualitative risk estimations presented in Table 5-3 are grouped into high (ICR > 1E-02), medium (1E-04 < ICR < 1E-02), low (1E-06 < ICR < 1E-04), and very low (ICR < 1E-06) risk categories based on results presented in Chapter 3 of the 100-HR-1 QRA (WHC 1993a). Sites that 
pose medium or high risks to human health under the occasional-use scenario are recommended to continue as IRM candidates.

Environmental hazard quotient ratings are from the qualitative ecological risk assessment that was performed in the QRA. Sites that have an EHQ rating $>1$ for radionuclides or non-radiological constituents present potentially adverse ecological impact and are recommended to continue as IRM candidates.

\subsubsection{Current Impact on Groundwater}

If LFI results indicate that a site is a current source of groundwater contamination or has a high probability of being a current contamination source, then the site is recommended to continue as an IRM candidate. The evaluation is based on review of monitoring well data from the 100-HR-3 Groundwater Operable Unit LFI (DOE-RL 1993d) and hydrogeological evaluation.

There are currently no waste or effluent discharges in the operable unit. Infiltration may be a driving force for movement of contaminants from the vadose zone to the saturated zone, however, the average annual precipitation and evapotranspiration are about equal (DOE-RL 1992a). Waste sites near the Columbia River (e.g. within $300 \mathrm{~m}$ ) may be affected by changes in groundwater elevations of the uppermost unconfined aquifer which is known to fluctuate in response to changes in river stage, and reversals of groundwater gradient are known to occur (DOE-RL 1992a). Contaminant transport modeling was not performed as part of the 100-HR-1 LFI or 100-HR-1 QRA. The data available are not sufficient to support such modeling, but are sufficient to support the conclusions made.

\subsubsection{Potential for Natural Attenuation}

The potential for the contaminants at a site to be reduced by natural attenuation, i.e., radioactive decay by the year 2018 , may be a consideration at sites where radionuclides with half-lives $<30$ years are the primary contaminants through the external exposure is the only pathway. Sites with excess risk attributed to radionuclides with half lives $<30$ years, i.e., $\mathrm{Co}-60$, Eu-152, and Eu-154, have potential for natural reduction of risk through radioactive decay. Natural attenuation is not a consideration for sites contaminated by metals, by radionuclides with half-lives $>30$ years, or where multiple exposure pathways drive the risk.

\subsection{HIGH-PRIORITY SITE IRM CANDIDATE RECOMMENDATIONS}

The final selection of IRM sites, priority of action, and order performance are decisions left to the Tri-Party Agreement signatories. Factors that the Tri-Party Agreement signatories may consider in the selection and prioritization of IRM sites include: 
- impact of IRM actions in relation to the 100 Area Environmental Impact Statement, e.g., disposition of the reactors

- access control

- relation to the IRM Program Plan recommendations

- $\quad$ land use

- $\quad$ point of compliance

- time of compliance

- feasibility

- bias-for-action

- threat to human health and the environment.

The high-priority sites recommended to continue as IRM candidates are identified in the "IRM Candidate" column of the Table 5-3. The recommendations are discussed below.

\subsubsection{6-H-1 Process Effluent Disposal Trench}

The 116-H-1 process effluent disposal trench is recommended to continue as an IRM candidate because the human health risks are medium, the EHQ is $>1$, the site contains concentrations of metals in excess of the MTCA Method B guidelines, and there is a high probability of current or future impact on the groundwater. Monitoring wells $\mathrm{H} 4-13$ and H4-45, constructed and sampled as part of the 100-HR-3 Groundwater Operable Unit LFI (DOE-RL 1993d), have elevated levels of Strontium-90 relative to upgradient wells (33 and $13 \mathrm{pCi} / \mathrm{L}$, respectively). The conceptual model of the site was confirmed by the LFI vadose borehole sampling activities. There is no potential for natural attenuation by the year 2018 due to the detected levels of Sr-90, and Tc-99.

\subsubsection{6-H-2 Effluent Disposal Trench}

The 116-H-2 effluent disposal trench is recommended to continue as an IRM candidate because the conceptual model is considered incomplete. The historical data are inconsistent with the LFI data. The LFI data indicate that the only contaminants present are very small amounts $(<1 \mathrm{pCi} / \mathrm{g})$ of naturally occurring radionuclides. The historical data indicate the presence of considerably higher amounts of man-made radionuclides. The vadose borehole drilled as part of the LFI investigation was located in the southwest corner of the 116-H-2 site. It is possible that a second borehole, located near the center of the trench, would detect contamination at similar levels to that detected by Dorian and Richards 
(1978). Additional investigation is required to either confirm the historical or existing LFI data. The status of the site as an IRM candidate should then be re-evaluated.

\subsubsection{6-H-3 Dummy Decontamination French Drain}

The 116-H-3 dummy decontamination french drain is recommended to be removed as a candidate for an IRM because the human health risk is low, the EHQ is $<1$, and no contaminants exceed MTCA Method B guidelines. The conceptual model of the site was confirmed by the LFI vadose borehole sampling activities. The probability of current impact to the groundwater is low. Natural attenuation of the site by the year 2018 will reduce the risk posed by the radionuclide contaminants.

\subsubsection{6-H-7 Process Effluent Retention Basin}

The 116-H-7 process effluent retention basin is recommended to continue as an IRM candidate because the human health risk is high, the EHQ is $>1$, the site contains concentrations of metals in excess of the MTCA Method B guidelines, and there is a high probability of current or future impact on the groundwater. Monitoring well H4-11, constructed and sampled as part of the 100-HR-3 LFI (DOE-RL 1993d), is located downgradient from the retention basin and has elevated gross alpha levels, as well as elevated levels of $\mathrm{Cr}, \mathrm{Sr}-90$, and $\mathrm{Tc}-99$ relative to upgradient wells. Monitoring well H4-13 also has elevated levels of Sr-90 relative to upgradient wells. The conceptual model of the site was confirmed by the LFI vadose borehole sampling activities. The potential for natural attenuation by the year 2018 is low due to presence of Sr-90 and Pu-239/240.

\subsubsection{6-H-9 Confinement Seal Pit Drainage Crib}

The 116-H-9 confinement seal pit drainage crib is recommended to be removed as an IRM candidate. The site has a low human health risk, an EHQ of $<1$, and no contaminants exceed MTCA Method B guidelines. Data from monitoring wells H3-1 and H4-49 (DOE-RL 1993d) indicate that the site is not impacting the groundwater. Natural attenuation of the site by the year 2018 will reduce the risk posed by the radionuclide contaminants and the associated pathway.

\subsubsection{6-H-5 Process Effluent Outfall Structure}

The 116-H-5 process effluent outfall structure is recommended to continue as an IRM candidate because the human health risk is medium. No concentrations of metals were found in the investigation of the analogous site that exceeded MTCA Method B guidelines. The probability is low that the outfall structure is currently impacting the groundwater. The conceptual model of the site was confirmed by the intrusive investigations of the 100-DR-1 LFI (DOE-RL 1993c). The potential for natural attenuation of the radionuclides is low since 
some of the radionuclides expected to be present ( $\mathrm{Ra}-226$ and $\mathrm{Th}-228$ ) have half-lives $>30$ years.

\subsubsection{Process Effluent Pipelines - Sludge and Soil}

The process effluent pipelines are recommended to continue as IRM candidates. Based on the sludge, the pipelines have a high human health risk and a probability of a current or future impact on groundwater. Because of the great linear extent of the process effluent pipelines across the 100-HR-1 Operable Unit, it is difficult to assess, from the existing monitoring wells, the current impact to groundwater posed by the process effluent pipelines. Because of the large volumes of effluent transported by the pipelines and their history of extensive leakage they are considered to be current sources of groundwater impact.

The conceptual model for the pipelines was confirmed by LFI activities. The potential for natural attenuation by the year 2018 is low due to presence of Sr-90 and $\mathrm{Pu}-239 / 240$.

\subsubsection{6-H-7 Sludge Burial Trench}

The 116-H-7 sludge burial trench is recommended to be removed as an IRM candidate. The site has a very low human health risk. The probability of the site impacting the groundwater is low. Natural attenuation of the site by the year 2018 will further reduce the risk posed by the radionuclide contaminants and the associated pathway.

\subsubsection{2-H-3 Effluent Pumping Station, 132-H-2 Exhaust Air Filter Building, 132-H-1 Reactor Exhaust Stack, and 116-H-4 Pluto Crib}

The 132-H-3 effluent pumping station, 132- $\mathrm{H}-2$ exhaust air filter building, 132- $\mathrm{H}-1$ reactor exhaust stack, and $116-\mathrm{H}-4$ pluto crib are recommended to be addressed as solid waste burial grounds.

Based on a qualitative risk estimate for these sites, the human health risk is low. Based on monitoring well information from the 100-HR-3 Groundwater Operable Unit LFI (DOE-RL 1993d), the probability of current impact on the groundwater by these sites is low. The potential for natural attenuation by the year 2018 of these sites is also low since some of the radionuclides expected to be present have half-lives $>30$ years.

\subsection{LOW-PRIORITY SITES RECOMMENDATIONS}

The low-priority sites investigated during the LFI were the 1607-H-2 septic tank, the 1607-H-4 septic tank, and the electrical facilities. These sites were determined to be low-priority sites and recommendations concerning IRM candidacy are not applicable. 
The 1607-H-2 site had levels of heavy metals which greatly exceeded the $95 \%$ UTL values and the MTCA Method B guidelines. Man-made radionuclides were also detected at the site. It is recommended that the priority rating (high or low) be reevaluated for this site.

The 1607-H-4 site had levels of heavy metals above the $95 \%$ UTL, SVOCs, pesticides, and man-made radionuclides. The concentrations of the heavy metals and the radionuclides were considerably lower than those found at the $1607-\mathrm{H}-2$ septic tank. The SVOCs detected are typical of coal tars or creosote preservatives. It is not recommended that the priority rating for this site be reevaluated.

The PCBs Aroclor-1254 or Aroclor-1260 were detected in small quantities in five of the surface-soil samples taken around the electrical facilities. The PCB contamination appears to be localized to visible spots. It is not recommended that the priority rating for this site be reevaluated. 


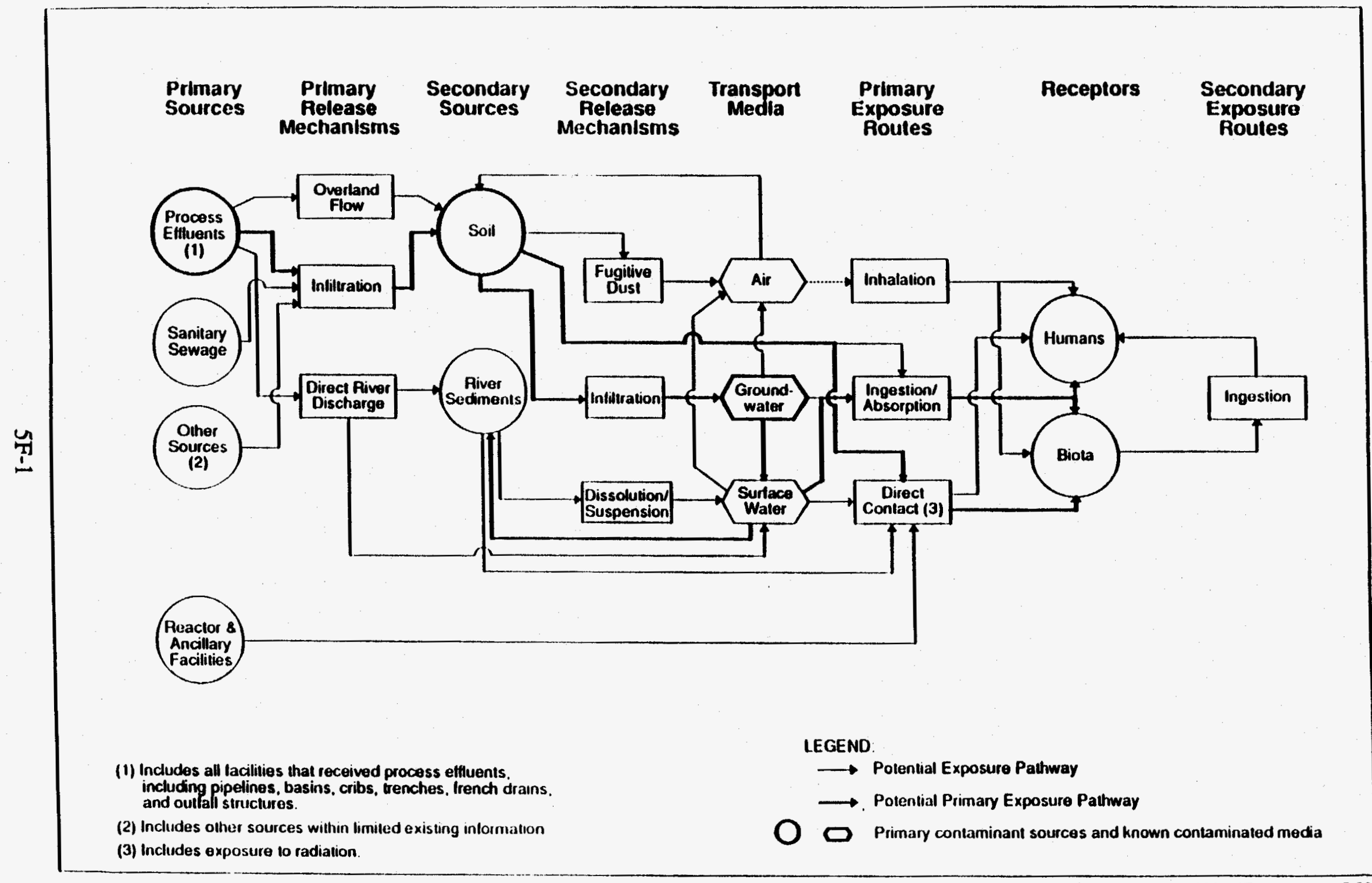




\begin{tabular}{|c|c|c|c|c|}
\hline Site & Structure/Process & Contaminant Source & $\begin{array}{l}\text { Contaminants of Potential } \\
\text { Concern }\end{array}$ & $\begin{array}{l}\text { Nature and Extent of } \\
\text { Contaminatione }\end{array}$ \\
\hline $\begin{array}{l}\text { 116-H-1 } \\
\text { Process } \\
\text { Effluent } \\
\text { Disposal } \\
\text { Trench }\end{array}$ & $\begin{array}{l}\text { Effluent disposal trench, } \\
\text { unlined - } 91 \mathrm{~m} \times 30 \mathrm{~m} \times \\
4.6 \mathrm{~m} \text { deep }\end{array}$ & $\begin{array}{l}\text { Received high activity effluent } \\
\text { produced by ruptured fuel } \\
\text { elements. Received sludge from } \\
116-\mathrm{H}-7 \text { retention basin when } 100- \\
\text { H Area was deactivated. Also } \\
\text { received } 90 \mathrm{~kg} \text { of sodium } \\
\text { dichromate. }\end{array}$ & $\begin{array}{l}\text { As, Cr, Pb, PNA } \\
\text { semivolatiles, Co-60, Sr-90, } \\
\text { Tc-99, Co-60, Cs-137, Pu- } \\
\text { 238, Pu-239/240, Ra-226, } \\
\text { Th-228, Th-232, Eu-152, Eu- } \\
\text { 154, Eu-155 }\end{array}$ & $\begin{array}{l}\text { Soil contamination to at least } \\
5.5 \mathrm{~m} \text {; possible groundwater } \\
\text { contamination }\end{array}$ \\
\hline $\begin{array}{l}\text { 116-H-2 } \\
\text { Effluent } \\
\text { Disposal } \\
\text { Trench }\end{array}$ & $\begin{array}{l}\text { Effluent disposal trench, } \\
\text { unlined }-84 \mathrm{~m} \times 30 \mathrm{~m} \\
1.8 \mathrm{~m} \text { deep }\end{array}$ & $\begin{array}{l}\text { Received decontamination wastes } \\
\text { from the } 132-\mathrm{H}-3 \text { effluent } \\
\text { pumping station during reactor } \\
\text { shutdown and standby periods. } \\
\text { Received } 600 \mathrm{~kg} \text { of sodium } \\
\text { dichromate. }\end{array}$ & $\begin{array}{l}\text { From historical data: Sr-90, } \\
\text { Eu-152, Eu-154, Eu-155, Co- } \\
60, \text { Cs-137, Tritium. LFI } \\
\text { data and historical data are } \\
\text { inconsistent. }\end{array}$ & $\begin{array}{l}\text { Soil contamination, based solely } \\
\text { on historical data, to } 3 \mathrm{~m} \text {. LFI } \\
\text { data and historical data are } \\
\text { inconsistent. Actual nature and } \\
\text { vertical extent of contaminants is } \\
\text { unknown. }\end{array}$ \\
\hline $\begin{array}{l}116-\mathrm{H}-3 \\
\text { Dummy } \\
\text { Decontamina } \\
\text { tion French } \\
\text { Drain } \\
\end{array}$ & $\begin{array}{l}\text { Vertical leaching drain, } \\
\text { unlined }-0.9 \mathrm{~m} \text { diameter } \\
\times 4.6 \mathrm{~m} \text { deep }\end{array}$ & $\begin{array}{l}\text { Received wastes generated during } \\
\text { decontamination of fuel-element } \\
\text { spacers. Received } 2000 \mathrm{~kg} \text { of } \\
\text { sodium dichromate, sodium } \\
\text { oxalate, and sodium sulfamate. }\end{array}$ & $\begin{array}{l}\text { Eu-152, Eu-154, Eu-155, Co- } \\
60, \text { Cs-137, Sr-90 }\end{array}$ & Soil contamination to $4.9 \mathrm{~m}$ \\
\hline $\begin{array}{l}\text { 116-H-7 } \\
\text { Process } \\
\text { Effluent } \\
\text { Retention } \\
\text { Basin } \\
\end{array}$ & $\begin{array}{l}\text { Retention basin, } \\
\text { reinforced concrete, } \\
\text { single containment - } \\
183 \mathrm{~m} \times 83 \mathrm{~m} \times 6 \mathrm{~m} \text { deep }\end{array}$ & $\begin{array}{l}\text { Held cooling water effluent from } \\
\mathrm{H} \text { reactor for cooling/decay } \\
\text { before release to the Columbia } \\
\text { River, large leaks of effluent to } \\
\text { the soil. }\end{array}$ & $\begin{array}{l}\text { As, Pb, Co-60, Cs-134, Cs- } \\
\text { 137, Eu-152, Eu-154, Eu- } \\
\text { 155, Pu-238, Pu-239/240, Sr- } \\
\text { 90, Ni-63, U }\end{array}$ & $\begin{array}{l}\text { Soil contamination to at least } 6 \mathrm{~m} \text {, } \\
\text { contaminated concrete } \\
\text { (foundation) and groundwater }\end{array}$ \\
\hline $\begin{array}{l}116-\mathrm{H}-9 \\
\text { Confinement } \\
\text { Seal Pit } \\
\text { Drainage } \\
\text { Crib }\end{array}$ & $\begin{array}{l}\text { Unlined crib - 3m x 3m } \\
\times 3 m \text { deep }\end{array}$ & $\begin{array}{l}\text { Received } 300,000 \text { liters of waste } \\
\text { from the } 132-\mathrm{H}-2 \text { reactor exhaust } \\
\text { air filter building seal pits. }\end{array}$ & None & No evidence of contamination \\
\hline
\end{tabular}




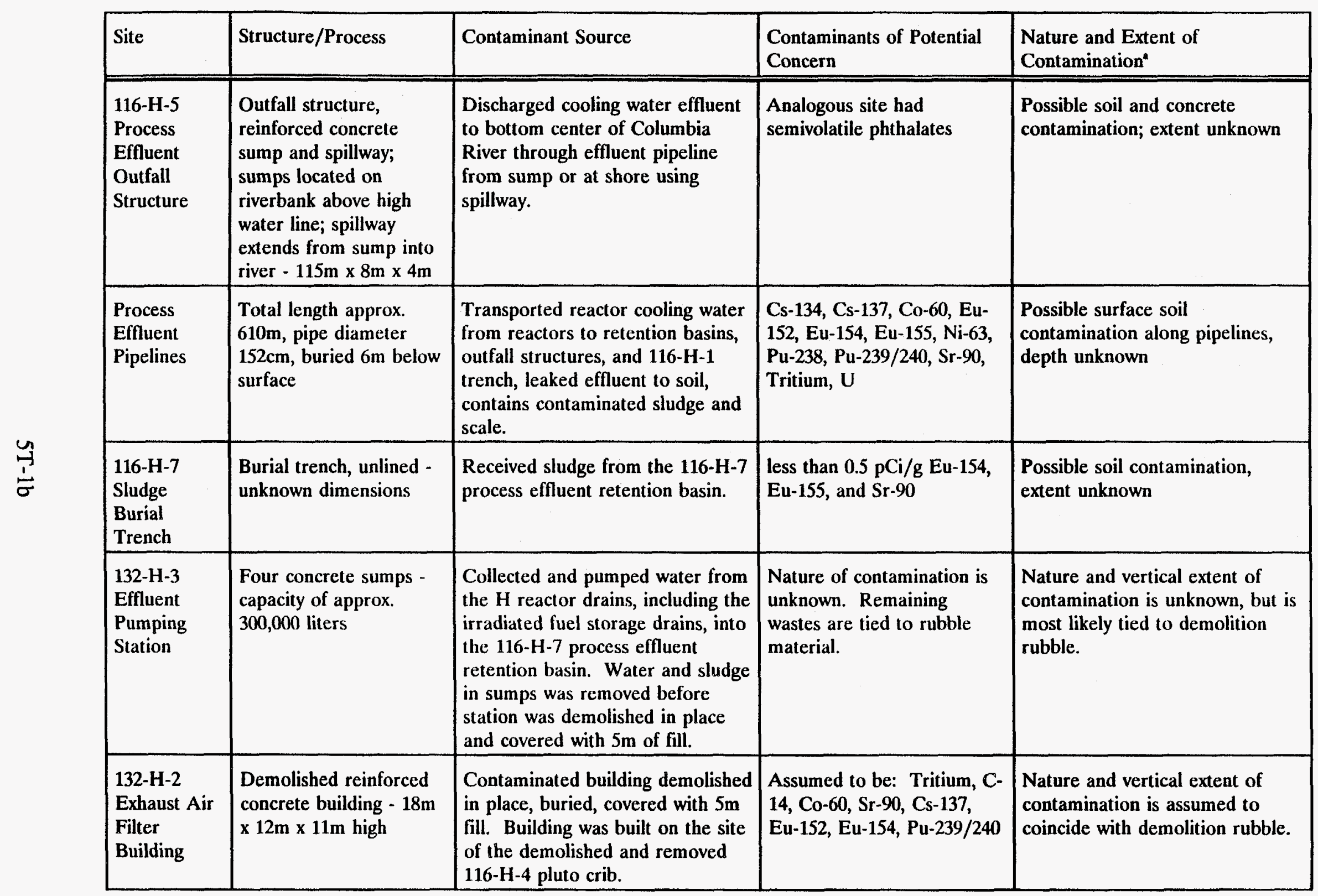


"Lateral extent of contamination is assumed to be equal to the facility dimensions, unless otherwise noted. The limited field investigation was not designed to establish the lateral (areal) extent of contamination

\begin{tabular}{|l|l|}
$\begin{array}{l}\text { Contaminants of Potential } \\
\text { Concern }\end{array}$ & $\begin{array}{l}\text { Nature and Extent of } \\
\text { Contamination }\end{array}$ \\
\hline $\begin{array}{l}\text { Assumed to be: Tritium, C- } \\
\text { 14, Co-60, Sr-90, Cs-137, } \\
\text { Eu-152 }\end{array}$ & $\begin{array}{l}\text { Nature and vertical extent of } \\
\text { contamination is assumed to } \\
\text { coincide with stack demolition } \\
\text { rubble. }\end{array}$ \\
\hline
\end{tabular}

\section{Received cooling water discharge Nature of any remaining}

contaminated by failed fuel

elements. Received $1000 \mathrm{~kg}$ of

sodium dichromate. Crib was

excavated and the material was

buried in the 118- $\mathrm{H}-5$ burial

ground. 132-H-2 exhaust air filter

building was later built on the

same site.
Nature and vertical extent of any remaining contamination is

unknown. Remaining

contamination is assumed to

coincide with building demolition rubble. 
Table 5-2 Hanford Site Background 95\% Upper Threshold Limits (UTLs) and Model Toxics Control Act (MTCA) Method B Guidelines for Inorganic Analytes

\begin{tabular}{|c|c|c|}
\hline Analyte $^{a}$ & $95 \% \operatorname{UTL}^{\mathrm{b}}(\mathrm{mg} / \mathrm{kg})$ & MTCA Method B $B^{c}(\mathrm{mg} / \mathrm{kg})$ \\
\hline $\begin{array}{l}\text { Alkalinity } \\
\text { Ammonia } \\
\text { Antimony } \\
\text { Arsenic } \\
\text { Barium }\end{array}$ & $\begin{array}{c}23,300 \\
28.2 \\
15.7^{d} \\
8.92 \\
171\end{array}$ & $\begin{array}{c}N / L \\
N / L \\
32 \\
60(1.4)^{e} \\
5,600\end{array}$ \\
\hline $\begin{array}{l}\text { Beryllium } \\
\text { Cadmium } \\
\text { Chloride } \\
\text { Chromium } \\
\text { Cobalt } \\
\end{array}$ & $\begin{array}{l}1.77 \\
0.66^{\mathrm{d}} \\
763 \\
27.9 \\
19.6 \\
\end{array}$ & $\begin{array}{c}400(0.23)^{e} \\
40 \\
N / L \\
400^{\dagger} \\
N / L \\
\end{array}$ \\
\hline $\begin{array}{l}\text { Copper } \\
\text { Fluoride } \\
\text { Lead } \\
\text { Lithium } \\
\text { Manganese }\end{array}$ & $\begin{array}{c}28.2 \\
12 \\
14.75 \\
37.1 \\
612\end{array}$ & $\begin{array}{c}2,960 \\
4,800 \\
U \\
N / L \\
8,000 \\
\end{array}$ \\
\hline $\begin{array}{l}\text { Mercury } \\
\text { Molybdenum } \\
\text { Nickel } \\
\text { Nitrate } \\
\text { Nitrite }\end{array}$ & $\begin{array}{l}1.25 \\
1.4^{\mathrm{d}} \\
25.3 \\
199 \\
21^{\mathrm{d}}\end{array}$ & $\begin{array}{c}24 \\
320 \\
U \\
N / L \\
8,000\end{array}$ \\
\hline $\begin{array}{l}\text { Ortho-phosphate } \\
\text { Selenium } \\
\text { Silicon } \\
\text { Silver } \\
\text { Sulfate }\end{array}$ & $\begin{array}{c}16 \\
5^{\mathrm{d}} \\
192 \\
2.7 \\
1,320\end{array}$ & $\begin{array}{l}N / L \\
N / L \\
N / L \\
240 \\
N / L\end{array}$ \\
\hline $\begin{array}{l}\text { Thallium } \\
\text { Titanium } \\
\text { Vanadium } \\
\text { Zinc } \\
\text { Zirconium }\end{array}$ & $\begin{array}{c}3.7^{\mathrm{d}} \\
3.570 \\
111 \\
79 \\
57.3\end{array}$ & $\begin{array}{c}5.6-7.2^{9} \\
N / L \\
560 \\
16,000 \\
N / L\end{array}$ \\
\hline \multicolumn{3}{|c|}{$\begin{array}{l}\text { Source: DOE-RL 1993a } \\
\text { NL = Not listed in MTCA Human Health Risk Based Method B Formula Values table for soil } \\
\text { a = Unavailable } \\
\text { a Analytes essentially non-toxic in soil are not listed (DOE-RL 1993b). These include aluminum, } \\
\text { calcium, iron, magnesium, potassium, sodium. } \\
\text { 95\%, confidence limit of the } 95 \text { th percentile of the data distribution } \\
\text { c Non-carcinogen risk-based concentration, no carcinogen risk except as shown in parenthesis } \\
\text { L Limit of detection } \\
\text { e Carcinogen risk-based concentration in parenthesis } \\
\text { Hexavalent chromium } \\
\text { gange of risk-based concentrations for thallium compounds }\end{array}$} \\
\hline
\end{tabular}




\begin{tabular}{|c|c|c|c|c|c|c|c|}
\hline \multirow[t]{2}{*}{ Waste Site } & \multicolumn{2}{|c|}{$\begin{array}{l}\text { Qualitative Risk } \\
\text { Estimation }\end{array}$} & \multirow[t]{2}{*}{$\begin{array}{c}\text { Conceptual } \\
\text { Model }\end{array}$} & \multirow[t]{2}{*}{$\begin{array}{l}\text { Exceeds } \\
\text { ARAR }\end{array}$} & \multirow{2}{*}{$\begin{array}{l}\text { Probable } \\
\text { Current } \\
\text { Impact on } \\
\text { Groundwater }\end{array}$} & \multirow{2}{*}{$\begin{array}{c}\text { Potential } \\
\text { for Natural } \\
\text { Attenuation } \\
\text { by } 2018\end{array}$} & \multirow{2}{*}{$\begin{array}{c}\text { IRM } \\
\text { Candidato } \\
\text { yes/no }\end{array}$} \\
\hline & $\begin{array}{l}\text { Low- } \\
\text { frequency } \\
\text { scenario }\end{array}$ & $\begin{array}{r}E H O \\
>1\end{array}$ & & & & & \\
\hline 116-H-1 Process Effluent Disposal Trench & Medium & Yos & Adequate & Yes & Yos & No & Yes \\
\hline 116-H-2 Effluent Disposal Trench & Low & Yes & Incomplete ${ }^{\circ}$ & No & No & No & Yes" \\
\hline 116-H-3 Dummy Decontamination French Drain & Low & No & Adequate & No & No & Yes & No \\
\hline 116-H-7 Process Effluent Retention Basin & High & Yes & Adequate & Yos & Yes & No & Yes \\
\hline 116-H-9 Confinement Seal Pit Drainage Crib & Low & No & Adequate & No & No & Yes & No \\
\hline 116-H-5 Process Effluent Outfall Structure & Medium: & $\ddot{-}$ & Adequate & No & No & No & Yes \\
\hline Process Effluent Pipelines (Soil) & Very Low & No & Adequate & No & Yes & No & Yes \\
\hline Process Effluent Pipelines (Sludge) & High & No & Adequate & No & Yos & No & Yes \\
\hline 116-H-7 Sludge Burial Trench & Very Low & - & Adequate & No & No & No & No \\
\hline 132-H-3 Effluent Pumping Station & Low & - & Adequate & Unknown & Unknown & Unknown & Yes \\
\hline 132-H-2 Exhaust Air Filter Building & Low & - & Adequate & Unknown & No & Unknown & Yes \\
\hline 132-H-1 Reactor Exhaust Stack & Low & $\because$ & Adequate & Unknown & No & Unknown & Yes \\
\hline 116-H-4 Pluto Cribb & Low & - & Adequate & Unknown & No & Unknown & Yes \\
\hline \multicolumn{8}{|c|}{$\begin{array}{l}\text { EHQ = Environmental Hazard Quotient calculated by the qualitative ecological risk assessment (WHC, 1993) } \\
:=\text { Not rated by the qualitative ecological risk assessment } \\
\text { = Data needed concerning nature and vertical extent of contamination, site remains an IRM candidate until data are aveilable. } \\
\text { = Conceptual model is considered incomplete due to discrepancies between the LFI data and the historical data. The LFI data indicates little or no } \\
\text { contamination which contradicts with the historical data. Additional investigation may be necessary. } \\
\text { ARAR = Applicable or Relevant and Appropriate Regulation, specifically the Washington state Model Toxics Control Act Method B concentration values for } \\
\text { soils (DOE-RL, } 1992 \text { a) } \\
\text { Shaded areas indicate driving factors keeping site as IRM candidate. }\end{array}$} \\
\hline
\end{tabular}




\subsection{REFERENCES}

Baker, D. A., and J. K. Soldat, 1992, "Methods for Estimating Doses to Organisms from Radioactive Materials Released into the Aquatic Environment," $P N L-8150$, Pacific Northwest Laboratory, Richland, Washington.

Beckstrom, J. F., 1987, "ARCL Calculations for Decommissioning the 116-H Stack," UNI-3827, UNC Nuclear Industries, Richland, Washington.

Beckstrom, J. F., and R. B. Loveland, 1986, "ARCL Calculations for Decommissioning the 117-D Filter Building," UNI-3870, UNC Nuclear Industries, Richland, Washington.

Beckstrom, J. F., and C. D. Wade, 1991, "100-HR-1 Radiological Surveys," WHC-MR-0275, Westinghouse Hanford Company, Richland, Washington.

DOE-RL, see U.S. Department of Energy, Richland Operations Office.

Dorian, J. J., and V. R. Richards, 1978, "Radiological Characterization of the Retired 100 Areas," UNI-946, United Nuclear Industries, Richland, Washington.

Ecology, EPA, and DOE/RL, 1990, "Hanford Federal Facility Agreement and Consent Order," Washington State Department of Ecology, Olympia, Washington, U.S. Environmental Protection Agency, Region X, Seattle, Washington, and U.S. Department of Energy, Richland Operations Office, Richland, Washington.

Ecology, EPA, and DOE/RL, 1991, "Hanford Federal Facility Agreement and Consent Order Change Packages," May 16, 1991, Washington State Department of Ecology, Olympia, Washington, U.S. Environmental Protection Agency, Region X, Seattle, Washington, and U.S. Department of Energy, Richland Operations Office, Richland, Washington.

Ekambaram, V., R. H. Montgomery, J. R. Doyle, and R. Swaroop, 1988, "A Statistical Model for Distribution of Chemicals in Groundwater," November/December, Hazardous Material Control.

EPA, see U.S. Environmental Protection Agency.

General Electric, 1963, "Hazards Summary Report: Volume 3-Description of the 100-B, 100-C, 100-D, 100-DR, 100-F and 100-H Production Reactor Plants," HW-74094, General Electric, Hanford Atomic Products Operation, Richland, Washington.

IAEA 1992, "Effects of Ionizing Radiation on Plants and Animals at Levels Implied by Current Radiation Protection Standards," STI/DOC/10/332, Technical Report Series No. 332, International Atomic Energy Agency, Vienna, Austria. 
Mitchell, T. M., and J. R. Kunk, 1991, "100-HR-1 Geophysical Surveys," WHC-MR-0263, Westinghouse Hanford Company, Richland, Washington.

Powers, E. W., 1986, "117-H Filter Building Decommissioning Individual Facility Report," UNI-2752, UNC Nuclear Industries, Richland, Washington.

Sackschewsky, M. R. and D. S. Landeen, 1992, "Fiscal Year 1991100 Areas CERCLA Ecological Investigations," WHC-EP-0448, Westinghouse Hanford Company, Richland, Washington.

Stenner, R. D., K. H. Cramer, K. A. Higley, S. J. Jette, D. A. Lamar, T. J. McLaughlin, D. R. Sherwood, and N. E. Van Houten, 1988, "Hazard Ranking System Evaluation of CERCLA Inactive Waste Sites at Hanford," PNL-6456, Pacific Northwest Laboratory, Richland, Washington.

U.S. Department of Energy (DOE, 1989), "Decommissioning of Eight Surplus Reactors at the Hanford Site, Richland, Washington; Draft Environmental Statement," DOE/EIS-0119D, U.S. Department of Energy, Washington, D.C.

U.S. Department of Energy, Richland Operations Office (DOE-RL), 1993a, "Hanford Site Background: Part 1, Soil Background for Nonradioactive Analytes," DOE/RL-92-24, Rev. 1, U.S. Department of Energy, Richland, Washington.

U.S. Department of Energy, Richland Operations Office (DOE-RL), 1993b, "Hanford Site Baseline Risk Assessment Methodology," DOE/RL-91-45, Rev. 2, U.S. Department of Energy, Richland, Washington.

U.S. Department of Energy, Richland Operations Office (DOE-RL), 1993c, "Limited Field Investigation Report for the 100-DR-1 Operable Unit," DOE/RL-93-29, Rev. 0, U.S. Department of Energy, Richland, Washington.

U.S. Department of Energy, Richland Operations Office (DOE-RL), 1993d, "Limited Field Investigation Report for the 100-HR-3 Operable Unit," DOE/RL-93-43, Rev. 0, U.S. Department of Energy, Richland, Washington.

U.S. Department of Energy, Richland Operations Office (DOE-RL), 1993e, "Limited Field Investigation Report for the 100-BC-1 Operable Unit," DOE/RL-93-06, Rev. 0, U.S. Department of Energy, Richland, Washington.

U.S. Department of Energy, Richland Operations Office (DOE-RL), 1992a, "RCRA Facility Investigation/Corrective Measures Study Work Plan for the 100-HR-1 Operable Unit, Hanford Site, Richland; Washington," DOE/RL-88-35, Rev. 0, U.S. Department of Energy, Richland, Washington. 
U.S. Department of Energy, Richland Operations Office (DOE-RL), 1992b, " "RCRA Facility Investigation/Corrective Measures Study Work Plan for the 100-HR-3 Operable Unit, Hanford Site, Richland, Washington," DOE/RL-88-36, Rev. 0, U.S. Department of Energy, Richland, Washington.

U.S. Department of Energy, Richland Operations Office (DOE-RL), 1992c, "100 Feasibility Study Phases 1 and 2," Hanford Site, Richland, Washington," $D O E / R L-92-11$, Draft A, U.S. Department of Energy, Richland, Washington.

U.S. Department of Energy, Richland Operations Office (DOE-RL), 1991a, "Hanford Site Past-Practice Strategy," DOE/RL-91-40, Draft A, U.S. Department of Energy, Washington, D.C.

U.S. Department of Energy, Richland Operations Office (DOE-RL), 1991b, "Hanford Site Waste Information Data System," data file accessed June 16, 1991, U.S. Department of Energy, Richland Operations Office, Richland, Washington.

U.S. Environmental Protection Agency (EPA), 1986, "Test Methods for Evaluating Solid Waste," SW-846, 3rd ed., U.S. Environmental Protection Agency, Office of Solid Waste and Emergency Response, Washington, D.C.

Weiss, S. and R. M. Mitchell, 1992, "A Synthesis of Ecological Data from the 100 Areas of the Hanford Site," WHC-EP-0601, Westinghouse Hanford Company, Richland, Washington.

Westinghouse Hanford Company (WHC), 1993a, "Qualitative Risk Assessment for the 100-HR-1 Source Operable Unit," WHC-SE-EN-RA-004, Rev. 0, Westinghouse Hanford Company, Richland, Washington.

Westinghouse Hanford Company (WHC), 1993b, "Spectral Gamma-Ray Log Report for the 100 Area Borehole Surveys," WHC-SD-EN-TI-123, Rev. 0, Westinghouse Hanford Company, Richland, Washington.

Westinghouse Hanford Company (WHC), 1992a, "Data Validation Report for the 100-HR-1 Operable Unit Vadose Boreholes," WHC-SD-EN-TI-082, Rev. 0, prepared by A.T. Kearney, Inc., for Westinghouse Hanford Company, Richland, Washington.

Westinghouse Hanford Company (WHC), 1992b, "Data Validation Report for the 100-HR-1 Operable Unit H-2 Septic Samples," WHC-SD-EN-TI-080, Rev. 0, prepared by A.T. Kearney, Inc., for Westinghouse Hanford Company, Richland, Washington.

Westinghouse Hanford Company (WHC), 1992c, "Data Validation Report for the 100-HR-1 Operable Unit H-4 Septic Samples," WHC-SD-EN-TI-081, Rev. 0, prepared by A.T. Kearney, Inc., for Westinghouse Hanford Company, Richland, Washington. 
Westinghouse Hanford Company (WHC), 1992d, "Data Validation Report for the 100-HR-1 Operable Unit Electrical Facilities," WHC-SD-EN-T1-079, Rev. 0, prepared by A.T. Kearney, Inc., for Westinghouse Hanford Company, Richland, Washington.

Westinghouse Hanford Company (WHC), 1991a, "Environmental Investigations and Site Characterization Manual," WHC-CM-7-7, Westinghouse Hanford Company, Richland, Washington.

Westinghouse Hanford Company (WHC), 1991b, "Health Physics Procedure Manual," WHC-IP-0692, Westinghouse Hanford Company, Richland, Washington.

Westinghouse Hanford Company (WHC), 1991c, "Description of Work for the 100-HR-1 Source Operable Unit," WHC-SD-EN-AP-066, Rev. 0, Westinghouse Hanford Company, Richland, Washington.

Westinghouse Hanford Company (WHC), 1991d, "Engineering Report for H Area Process Effluent Line Examination," WHC-SD-NR-ER-092, Westinghouse Hanford Company, Richland, Washington.

Westinghouse Hanford Company (WHC), 1990, "Sample Management and Administration Manual," WHC-CM-5-3, Westinghouse Hanford Company, Richland, Washington.

Westinghouse Hanford Company (WHC), 1988a, "Interim Status Post-Closure Permit Application: 183-H Solar Evaporation Basins," DOE/RL 88-04, Westinghouse Hanford Company for U.S. Department of Energy, Richland Operations Office, Richland, Washington.

WHC, see Westinghouse Hanford Company. 
DOE/RL-93-51, Rev. 0

Appendix A

RESULTS OF LABORATORY ANALYSES FOR HIGH-PRIORITY SITES 


\begin{tabular}{|c|c|c|c|c|c|c|c|c|c|c|c|c|c|c|}
\hline \multirow[b]{3}{*}{ Analyte } & \multicolumn{14}{|c|}{ Sample Numbers } \\
\hline & \multicolumn{2}{|l|}{ B05WV5" } & \multicolumn{2}{|l|}{ BO5WV6 } & \multicolumn{2}{|l|}{$B 05 W V 7^{b, c}$} & \multicolumn{2}{|l|}{ B05WV8 } & \multicolumn{2}{|l|}{ Bo5WV9 } & \multicolumn{2}{|l|}{ Bo5WWo } & \multicolumn{2}{|l|}{ Bo5WW4 } \\
\hline & $\begin{array}{l}\text { top: } 10.0 \mathrm{ft} \\
\text { bottom: } \\
12.0 \mathrm{ft} \\
\end{array}$ & 0 & $\begin{array}{l}\text { top: } 13.6 \mathrm{ft} \\
\text { bottom: } \\
15.6 \mathrm{ft} \\
\end{array}$ & $a$ & $\begin{array}{l}\text { top: } 13.6 \mathrm{ft} \\
\text { bottom: } \\
15.6 \mathrm{ft} \\
\end{array}$ & a & $\begin{array}{l}\text { top: } 15.0 \mathrm{ft} \\
\text { bottom: } \\
17.0 \mathrm{ft} \\
\end{array}$ & $\mathbf{Q}$ & $\begin{array}{l}\text { top: } 16.5 \mathrm{ft} \\
\text { bottom: } \\
17.8 \mathrm{ft} \\
\end{array}$ & $a$ & $\begin{array}{l}\text { top: } 19.3 \mathrm{ft} \\
\text { bottom: } \\
20.8 \mathrm{ft}\end{array}$ & $a$ & $\begin{array}{l}\text { top: } 24.0 \mathrm{ft} \\
\text { bottom: } \\
25.1 \mathrm{ft}\end{array}$ & 0 \\
\hline \multicolumn{15}{|l|}{ Inorganic Analysis ${ }^{d}$} \\
\hline Aluminum & 6170.00 & & 7500.00 & & 6890.00 & & 5550.00 & & 4800.00 & & 5560.00 & & 5720.00 & \\
\hline Antimony & 1.70 & $u$ & 1.60 & $u$ & 4.60 & $\mathbf{u}$ & 1.60 & $\mathbf{u}$ & 1.60 & $\mathbf{u}$ & 1.50 & $u$ & 1.60 & $u$ \\
\hline Arsenic & 37.90 & & 25.30 & $\mathrm{~J}$ & 27.60 & $\mathrm{~J}$ & 7.30 & $\mathrm{~J}$ & 1.80 & $\mathbf{u}$ & 1.20 & $u$ & 1.20 & $u$ \\
\hline Barium & 72.30 & & 74.50 & & 66.00 & & 59.60 & & 52.90 & & 56.80 & & 72.50 & \\
\hline Beryllium & 0.77 & $B$ & 0.56 & $\mathbf{u}$ & 0.46 & & 0.55 & $u$ & 0.20 & $\mathbf{u}$ & 0.54 & $u$ & 0.45 & $u$ \\
\hline Cadmium & 0.21 & $u$ & 0.20 & $u$ & 0.80 & $u$ & 0.20 & $\mathbf{u}$ & 0.20 & $u$ & 0.19 & $u$ & 0.20 & $u$ \\
\hline Calcium & 4650.00 & & 5520.00 & & 4960.00 & & 4120.00 & & 3180.00 & & 4330.00 & & 4520.00 & \\
\hline Chromium & 16.00 & & 18.90 & & 23.50 & & 17.90 & & 29.60 & & 12.50 & & 10.60 & \\
\hline Cobalt & 7.70 & $\mathrm{~B}$ & 8.30 & & 9.30 & & 7.40 & & 6.40 & & 8.10 & & 9.90 & \\
\hline Copper & 19.00 & & 19.50 & & 11.80 & & 19.30 & & 20.50 & & 17.60 & & 16.90 & \\
\hline Cyanide & 5.20 & $u$ & 5.30 & $u$ & 5.00 & $u$ & 5.20 & $\mathbf{u}$ & 5.10 & $u$ & 5.00 & $u$ & 4.70 & $u$ \\
\hline Iron & 15800.00 & & 16900.00 & & 17900.00 & & 15800.00 & & 12700.00 & & 15000.00 & & 18700.00 & \\
\hline Lead & 187.00 & & 145.00 & $J$ & 118.00 & $\mathrm{~J}$ & 36.90 & $J$ & 82.10 & $\mathrm{~J}$ & 2.80 & $\mathrm{~J}$ & 2.50 & $J$ \\
\hline Magnesium & 4120.00 & & 4630.00 & & 3930.00 & & 4210.00 & & 3420.00 & & 3940.00 & & 4190.00 & \\
\hline Manganese & 278.00 & & 292.00 & & 275.00 & & 252.00 & & 215.00 & & 242.00 & & 266.00 & \\
\hline Mercury & 0.10 & $u$ & 0.10 & $u$ & 0.05 & & 0.09 & $u$ & 0.09 & $u$ & 0.09 & $u$ & 0.10 & $u$ \\
\hline Nickel & 10.80 & & 11.50 & & 13.90 & & 9.30 & & 7.90 & & 9.60 & & 9.00 & \\
\hline Potassium & 1320.00 & & 1270.00 & & 1160.00 & & 707.00 & & 509.00 & & 575.00 & & 946.00 & \\
\hline Selenium & 4.10 & $u$ & 0.82 & $\mathbf{u}$ & 0.40 & $u$ & 0.83 & $u$ & 4.10 & $u$ & 4.20 & $u$ & 0.77 & $u$ \\
\hline Silver & 0.42 & $u$ & 0.40 & $u$ & 0.60 & $\mathrm{~J}$ & 0.40 & $u$ & 0.40 & $u$ & 0.39 & $u$ & 0.40 & u \\
\hline Sodium & 179.00 & B & 207.00 & & 249.00 & $\mathbf{u}$ & 205.00 & & 249.00 & & 399.00 & & 480.00 & \\
\hline Thallium & 0.61 & $u$ & 0.62 & $\mathbf{u}$ & 0.40 & $\mathbf{u}$ & 0.62 & $u$ & 0.62 & $u$ & 0.63 & $\mathbf{u}$ & 0.58 & $u$ \\
\hline Vanadium & 32.00 & & 35.80 & & 40.80 & & 32.90 & & 32.80 & & 38.20 & & 51.00 & \\
\hline Zinc & 48.70 & & 53.10 & & 52.70 & $J$ & 45.10 & & 38.60 & & 30.50 & & 39.10 & \\
\hline \multicolumn{15}{|l|}{ Organic Analysis } \\
\hline 1,1,1-Trichloroethane & 5 & $u$ & 5 & $\mathbf{u}$ & 5 & $u$ & 5 & $u$ & 5 & $\mathbf{u}$ & 5 & $u$ & 5 & $\mathrm{u}$ \\
\hline
\end{tabular}


Table A-1 Chemical Analysis Results for Borehole 116-H-1 (page 2 of 6 )

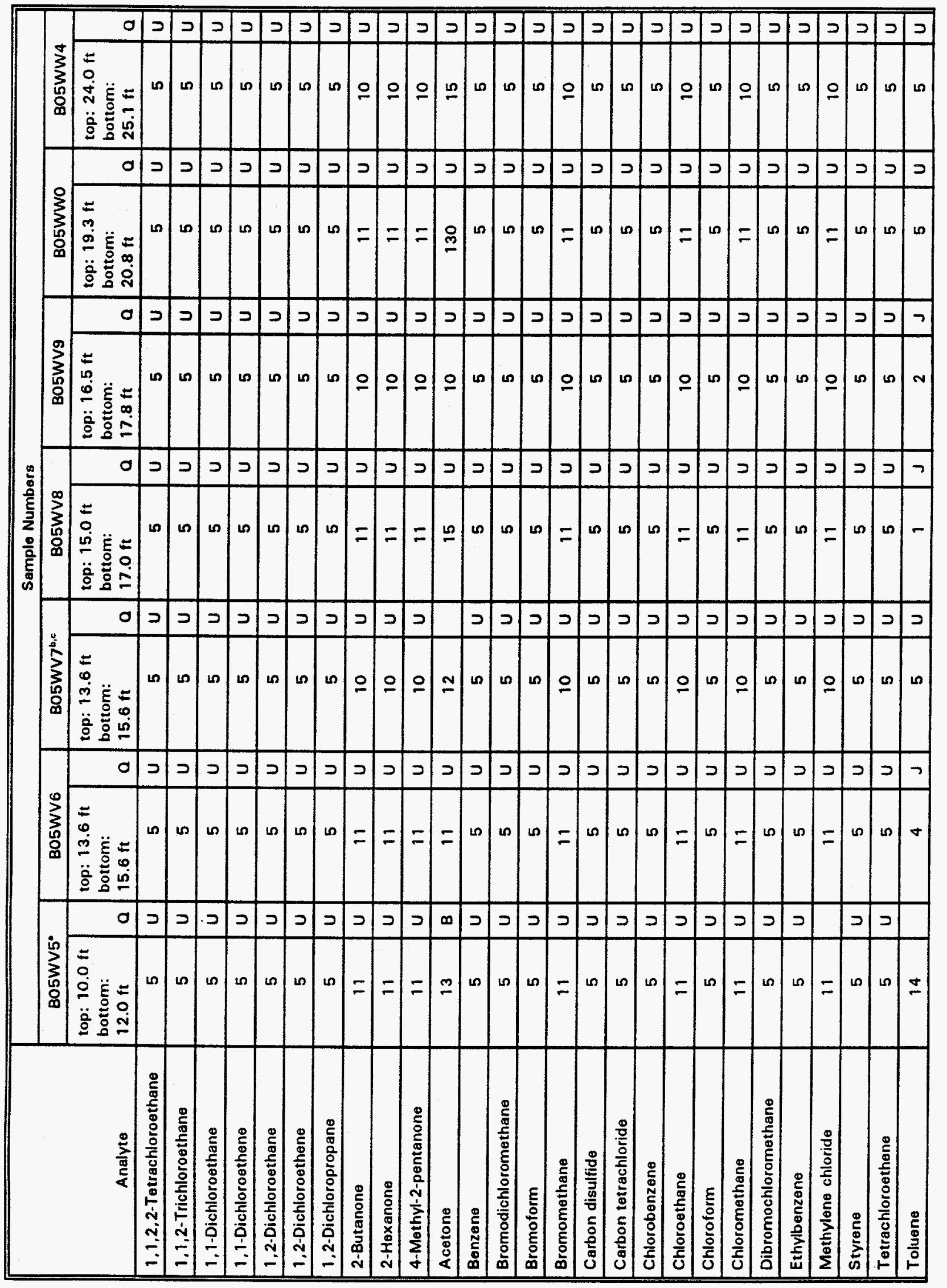




\begin{tabular}{|c|c|c|c|c|c|c|c|c|c|c|c|c|c|c|}
\hline \multirow[b]{3}{*}{ Analvte } & \multicolumn{14}{|c|}{ Sample Numbers } \\
\hline & \multicolumn{2}{|c|}{ B05WV5: } & \multicolumn{2}{|l|}{ B05WV6 } & \multicolumn{2}{|c|}{ Bo5WV7 $7^{6, c}$} & \multicolumn{2}{|l|}{ Bo5WV8 } & \multicolumn{2}{|l|}{ Bo5WV9 } & \multicolumn{2}{|l|}{ Bo5WWo } & \multicolumn{2}{|l|}{ Bo5WW4 } \\
\hline & $\begin{array}{l}\text { top: } 10.0 \mathrm{ft} \\
\text { bottom: } \\
12.0 \mathrm{ft}\end{array}$ & $\mathbf{Q}$ & $\begin{array}{l}\text { top: } 13.6 \mathrm{ft} \\
\text { bottom: } \\
15.6 \mathrm{ft}\end{array}$ & $\mathbf{a}$ & $\begin{array}{l}\text { top: } 13.6 \mathrm{ft} \\
\text { bottom: } \\
15.6 \mathrm{ft} \\
\end{array}$ & $\mathbf{a}$ & $\begin{array}{l}\text { top: } 15.0 \mathrm{ft} \\
\text { bottom: } \\
17.0 \mathrm{ft}\end{array}$ & $\mathbf{a}$ & $\begin{array}{l}\text { top: } 16.5 \mathrm{ft} \\
\text { bottom: } \\
17.8 \mathrm{ft}\end{array}$ & $\mathbf{0}$ & $\begin{array}{l}\text { top: } 19.3 \mathrm{ft} \\
\text { bottom: } \\
20.8 \mathrm{ft}\end{array}$ & $\mathbf{Q}$ & $\begin{array}{l}\text { top: } 24.0 \mathrm{ft} \\
\text { bottom: } \\
25.1 \mathrm{ft} \\
\end{array}$ & $\mathbf{a}$ \\
\hline Trichloroethene & 5 & $\mathbf{u}$ & 5 & $\mathbf{u}$ & 5 & $u$ & 5 & $u$ & 5 & $\mathbf{u}$ & 5 & $\mathbf{u}$ & 5 & $\mathbf{u}$ \\
\hline Vinyl acetate & 11 & $u$ & 11 & $u$ & 10 & $u$ & 11 & $u$ & 10 & $\mathbf{u}$ & 11 & $\mathbf{u}$ & 10 & $u$ \\
\hline Vinyl chloride & 11 & $\mathbf{u}$ & 11 & $\mathbf{u}$ & 10 & $\mathbf{u}$ & 11 & $\mathbf{U}$ & 10 & $\mathbf{u}$ & 11 & $\mathbf{u}$ & 10 & $u$ \\
\hline Xylenes (total) & 5 & $u$ & 5 & $\mathbf{u}$ & 5 & $\mathbf{u}$ & 5 & $\mathrm{u}$ & 5 & $\mathbf{u}$ & 5 & $\mathbf{u}$ & 5 & $u$ \\
\hline cis-1,3-Dichloropropene & 5 & $\mathbf{u}$ & 5 & $u$ & 5 & $\mathbf{u}$ & 5 & $\mathbf{u}$ & 5 & $\mathbf{u}$ & 5 & $\mathbf{u}$ & 5 & $\mathbf{u}$ \\
\hline trans-1,3-Dichloropropene & 5 & $u$ & 5 & $\mathbf{u}$ & 5 & $\mathbf{u}$ & 5 & $u$ & 5 & $\mathbf{u}$ & 5 & $\mathbf{u}$ & 5 & $\mathbf{u}$ \\
\hline \multicolumn{15}{|l|}{ Semivolatile Organics" } \\
\hline 1,2,4-Trichlorobenzene & & & 340 & $u$ & 1800 & $\mathrm{u}$ & 340 & $\mathbf{u}$ & 340 & $\mathbf{u}$ & 350 & $\mathbf{u}$ & 330 & $u$ \\
\hline 1,2-Dichlorobenzene & & & 340 & $u$ & 1800 & $u$ & 340 & $\mathbf{u}$ & 340 & $\mathbf{u}$ & 350 & $\mathbf{u}$ & 330 & $\mathbf{u}$ \\
\hline 1,3-Dichlorabenzene & & & 340 & $u$ & 1800 & $u$ & 340 & $u$ & 340 & $\mathbf{u}$ & 350 & $\mathbf{u}$ & 330 & $u$ \\
\hline 1,4-Dichlorobenzene & & & 340 & $u$ & 1800 & $\mathbf{u}$ & 340 & $\mathbf{u}$ & 340 & $\mathbf{u}$ & 350 & $\mathbf{u}$ & 330 & $u$ \\
\hline 2,4,5-Trichlorophenol & & & 1700 & $\mathbf{u}$ & 8800 & $\mathbf{u}$ & 1700 & $\mathbf{u}$ & 1600 & $\mathbf{u}$ & 1700 & $\mathbf{u}$ & 1600 & $\mathbf{u}$ \\
\hline 2,4,6-Trichlorophenol & & & 340 & $\mathrm{u}$ & 1800 & $\mathbf{u}$ & 340 & $u$ & 340 & $\mathbf{u}$ & 350 & $u$ & 330 & $u$ \\
\hline 2,4-Dichlorophenol & & & 340 & $\mathbf{u}$ & 1800 & $u$ & 340 & $\mathbf{u}$ & 340 & $\mathbf{u}$ & 350 & $\mathbf{u}$ & 330 & $u$ \\
\hline 2,4-Dimethylphenol & & & 340 & $u$ & 1800 & $\mathbf{u}$ & 340 & $\mathbf{U}$ & 340 & $\mathbf{u}$ & 350 & $\mathbf{u}$ & 330 & $\mathbf{u}$ \\
\hline 2,4-Dinitrophenol & & & 1700 & u & 8800 & $u$ & 1700 & $\mathbf{u}$ & 1600 & $\mathbf{u}$ & 1700 & $u$ & 1600 & $u$ \\
\hline 2,4-Dinitrotoluene & & & 340 & $u$ & 1800 & $\mathbf{u}$ & 340 & $\mathbf{u}$ & 340 & $\mathbf{u}$ & 350 & $\mathbf{u}$ & 330 & $\mathbf{u}$ \\
\hline 2,6-Dinitrotoluene & & & 340 & $u$ & 1800 & $u$ & 340 & $u$ & 340 & $\mathbf{u}$ & 350 & $u$ & 330 & $u$ \\
\hline 2.Chloronaphthalene & & & 340 & $\mathbf{u}$ & 1800 & $u$ & 340 & $U$ & 340 & $\mathbf{u}$ & 350 & 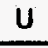 & 330 & $u$ \\
\hline 2-Chlorophenol & & & 340 & $U$ & 1800 & $u$ & 340 & $\mathbf{U}$ & 340 & $\mathbf{u}$ & 350 & $\mathbf{U}$ & 330 & $u$ \\
\hline 2-Methylnaphthalene & & & 42 & $\mathrm{~J}$ & 350 & $u$ & 340 & $\mathbf{u}$ & 340 & $u$ & 350 & $u$ & 330 & $u$ \\
\hline 2-Methylphenol & & & 340 & $u$ & 1800 & $u$ & 340 & $u$ & 340 & $\mathbf{u}$ & 350 & $\mathbf{U}$ & 330 & $\mathbf{u}$ \\
\hline 2-Nitroaniline & & & 1700 & $\mathbf{u}$ & 8800 & $u$ & 1700 & $\mathbf{u}$ & 1600 & $\mathbf{u}$ & 1700 & $\mathbf{u}$ & 1600 & $u$ \\
\hline 2-Nitrophenol & & & 340 & U & 1800 & u & 340 & $\mathbf{u}$ & 340 & $\mathbf{u}$ & 350 & $\mathbf{u}$ & 330 & $\mathbf{u}$ \\
\hline 3-Nitroaniline & & & 1700 & $u$ & 8800 & $\mathbf{u}$ & 1700 & $\mathbf{U}$ & 1600 & $\mathbf{u}$ & 1700 & $\underline{u}$ & 1600 & $\mathbf{u}$ \\
\hline 3,3-Dichlorbenzidine & & & 690 & $u$ & 3500 & $u$ & 690 & $\mathbf{u}$ & 670 & $\mathbf{u}$ & 690 & $\mathbf{u}$ & 660 & $u$ \\
\hline 4,6-Dinitro-2-methyl phenol & & & 1700 & $u$ & 8800 & $\mathbf{u}$ & 1700 & $\mathbf{u}$ & 1600 & $\mathbf{u}$ & 1700 & $\mathbf{u}$ & 1600 & $u$ \\
\hline
\end{tabular}




\begin{tabular}{|c|c|c|c|c|c|c|c|c|c|c|c|c|c|c|}
\hline \multirow[b]{3}{*}{ Analyte } & \multicolumn{14}{|c|}{ Sample Numbers } \\
\hline & \multicolumn{2}{|l|}{ Bo5WV5: } & \multicolumn{2}{|l|}{ Bo5WV6 } & \multicolumn{2}{|c|}{$B 05 W V 7^{b, c}$} & \multicolumn{2}{|l|}{ Bo5WV8 } & \multicolumn{2}{|l|}{ Bo5WV9 } & \multicolumn{2}{|c|}{ Bo5Wwo } & \multicolumn{2}{|l|}{ Bo5WW4 } \\
\hline & $\begin{array}{l}\text { top: } 10.0 \mathrm{ft} \\
\text { bottom: } \\
12.0 \mathrm{ft}\end{array}$ & 0 & $\begin{array}{l}\text { top: } 13.6 \mathrm{ft} \\
\text { bottom: } \\
15.6 \mathrm{ft}\end{array}$ & a & $\begin{array}{l}\text { top: } 13.6 \mathrm{ft} \\
\text { bottom: } \\
15.6 \mathrm{ft}\end{array}$ & 0 & $\begin{array}{l}\text { top: } 15.0 \mathrm{ft} \\
\text { bottom: } \\
17.0 \mathrm{ft}\end{array}$ & a & $\begin{array}{l}\text { top: } 16.5 \mathrm{ft} \\
\text { bottom: } \\
17.8 \mathrm{ft}\end{array}$ & a & $\begin{array}{l}\text { top: } 19.3 \mathrm{ft} \\
\text { bottom: } \\
20.8 \mathrm{ft}\end{array}$ & $\mathbf{Q}$ & $\begin{array}{l}\text { top: } 24.0 \mathrm{ft} \\
\text { bottom: } \\
25.1 \mathrm{ft}\end{array}$ & a \\
\hline 4-Bromophenylphenvl ether & & & 340 & $u$ & 1800 & $u$ & 340 & $u$ & $340^{\circ}$ & $u$ & 350 & $u$ & 330 & $u$ \\
\hline 4-Chloro-3-methylphanol & & & 340 & $u$ & 1800 & $u$ & 340 & $u$ & 340 & $u$ & 350 & $u$ & 330 & $u$ \\
\hline 4-Chlorophenylphenyl ather & & & 340 & $u$ & 1800 & $u$ & 340 & $u$ & 340 & $u$ & 350 & $u$ & 330 & $u$ \\
\hline 4-Nitroaniline & & & 1700 & $u$ & 8800 & $u$ & 1700 & $u$ & 1600 & $u$ & 1700 & $u$ & 1600 & $u$ \\
\hline 4-Nitrophenol & & & 1700 & $u$ & 8800 & $u$ & 1700 & $u$ & 1600 & $u$ & 1700 & $u$ & 1600 & $u$ \\
\hline Acenaphthene & & & 210 & $\mathrm{~J}$ & 2100 & & 340 & $u$ & 340 & $u$ & 350 & $u$ & 330 & u \\
\hline Acenaphthylene & & & 340 & $u$ & 1800 & $u$ & 340 & $u$ & 340 & $u$ & 350 & $u$ & 330 & $u$ \\
\hline Anthracene & & & 430 & $J$ & 4100 & $\mathrm{~J}$ & 340 & $\mathrm{u}$ & 340 & $u$ & 350 & $u$ & 330 & $u$ \\
\hline Benzo(k)fluoranthene & & & 760 & $J$ & 7200 & $J$ & 340 & $u$ & 340 & $u$ & 350 & $u$ & 330 & u \\
\hline Benzoic acid & & & 1700 & $u$ & 8800 & $u$ & 1700 & $u$ & 1600 & $u$ & 1700 & $u$ & 1600 & $u$ \\
\hline Benzyl alcohol & & & 340 & $\mathrm{u}$ & 1800 & $\mathrm{u}$ & 340 & $u$ & 340 & $u$ & 350 & $u$ & 330 & $u$ \\
\hline Bis(2-chloroethoxy)methane & & & 340 & $u$ & 1800 & $u$ & 340 & $u$ & 340 & $u$ & 350 & $u$ & 330 & $u$ \\
\hline Bis(2-chloroethyl)ether & & & 340 & $u$ & 1800 & $\mathbf{u}$ & 340 & $u$ & 340 & $u$ & 350 & $u$ & 330 & $u$ \\
\hline Bis(2-chloroisopropyl)ether & & & 340 & $\mathrm{u}$ & 1800 & $u$ & 340 & $u$ & 340 & $u$ & 350 & $u$ & 330 & $u$ \\
\hline Bis(2-ethylhexyl)phthalate & & & 340 & $u$ & 1800 & $u$ & 68 & $\mathrm{~J}$ & 340 & $u$ & 350 & $u$ & 330 & $u$ \\
\hline Butylbenzylphthalate & & & 340 & $u$ & 1800 & $u$ & 340 & $u$ & 340 & $u$ & 350 & $u$ & 330 & $u$ \\
\hline Chrysene & & & 920 & $J$ & 7800 & $\mathrm{~J}$ & 340 & $\mathbf{u}$ & 77 & J & 350 & $u$ & 330 & $u$ \\
\hline Di-n-butylphthalate & & & 59 & $J$ & 1800 & $u$ & 68 & $J$ & 50 & J & 350 & $u$ & 46 & J \\
\hline Di-n-octylphthalate & & & 340 & $u$ & 1800 & $u$ & 340 & $u$ & 340 & $u$ & 350 & $\mathrm{u}$ & 330 & $u$ \\
\hline
\end{tabular}




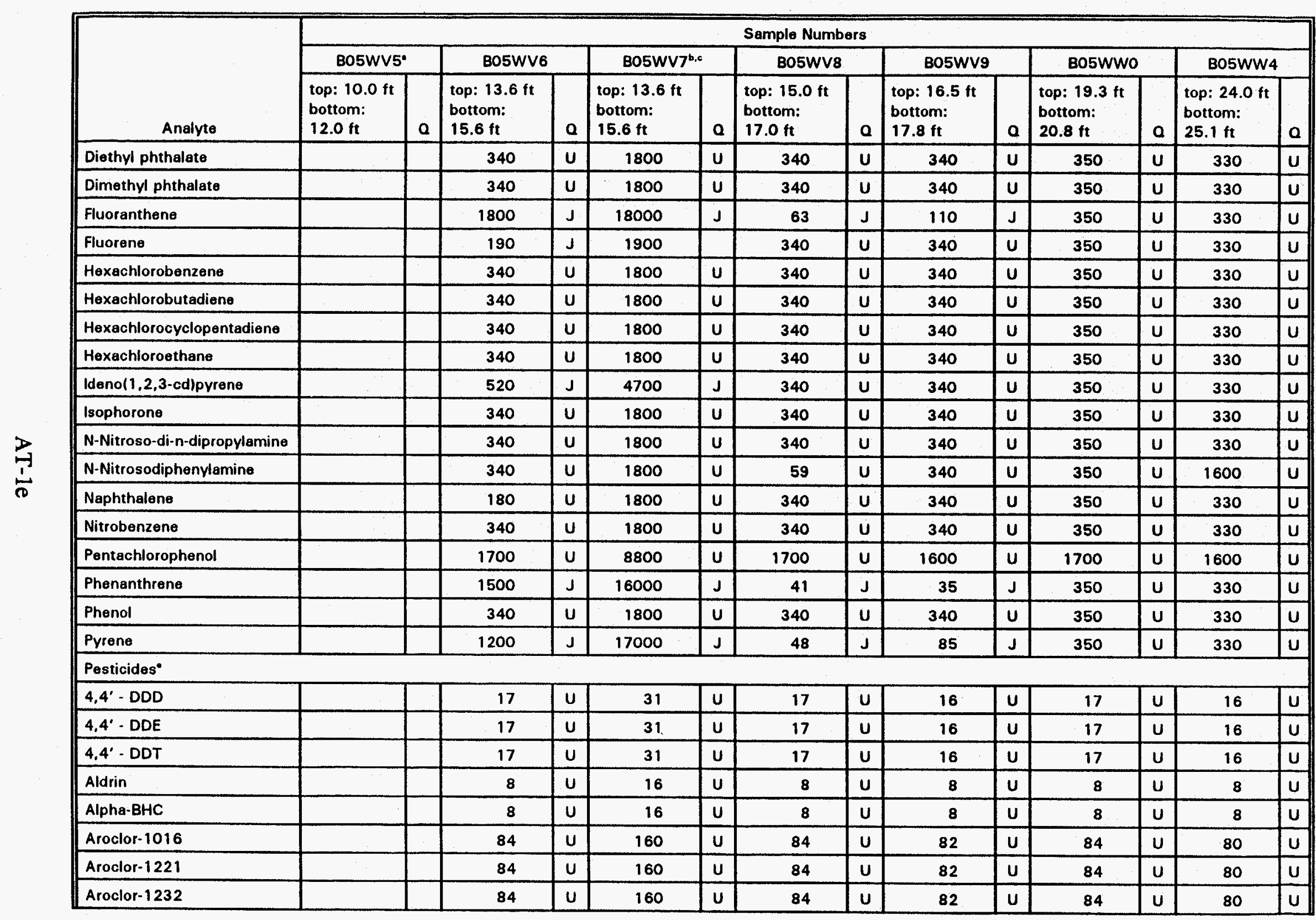


Table A-1 Chemical Analysis Results for Borehole 116-H-1 (page 6 of 6 )

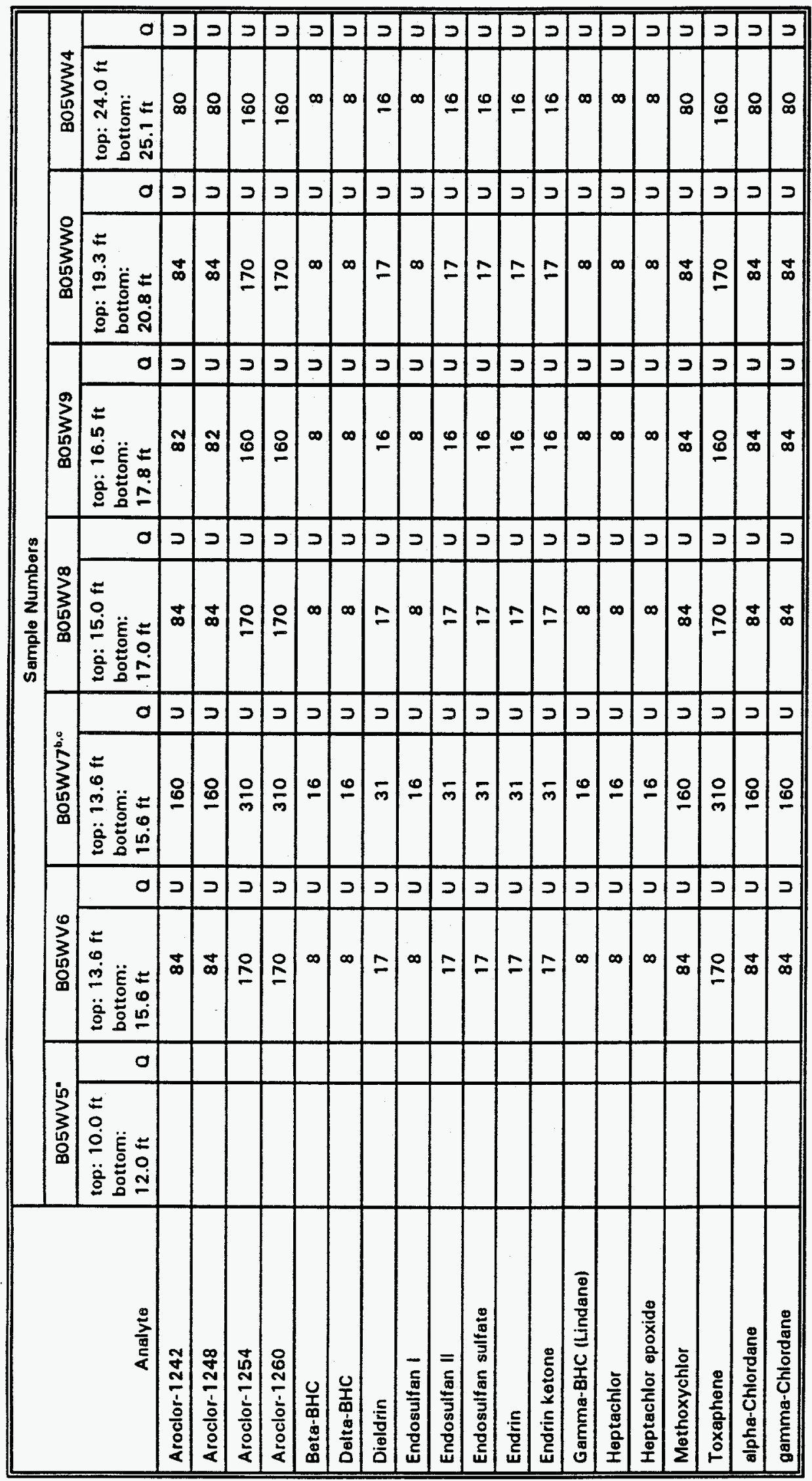

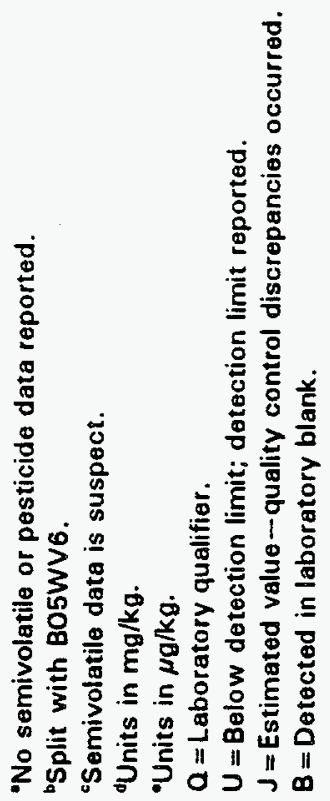


DOE/RL-93-51, Rev. 0

Table A-2 Chemical Analysis Results for Borehole 116-H-2 (page 1 of 6 )

\begin{tabular}{|c|c|c|c|c|c|c|}
\hline \multirow[b]{3}{*}{ Analyte } & \multicolumn{6}{|c|}{ SAMPLE NUMBERS } \\
\hline & \multicolumn{2}{|l|}{ B05WW5 } & \multicolumn{2}{|l|}{ B05WW6 } & \multicolumn{2}{|l|}{$\mathrm{B} 05 \mathrm{WW} 7^{\mathrm{a}}$} \\
\hline & $\begin{array}{l}\text { top: } 9.9 \mathrm{ft} \\
\text { bottom: } 12.1 \mathrm{ft}\end{array}$ & $Q$ & $\begin{array}{l}\text { top: } 14.9 \mathrm{ft} \\
\text { bottom: } 17.2 \mathrm{ft}\end{array}$ & $Q$ & $\begin{array}{l}\text { top: } 14.9 \mathrm{ft} \\
\text { bottom: } 17.2 \mathrm{ft}\end{array}$ & $\mathrm{Q}$ \\
\hline \multicolumn{7}{|l|}{ Inorganic Analysis $^{\mathbf{b}}$} \\
\hline Aluminum & 4560.00 & & 5640.00 & & 4900.00 & \\
\hline Antimony & 1.60 & $\mathrm{U}$ & 1.60 & $\mathrm{U}$ & 1.60 & $\mathrm{U}$ \\
\hline Arsenic & 1.40 & $\mathrm{U}$ & 2.00 & & 2.10 & \\
\hline Barium & 57.60 & & 55.30 & & 69.90 & \\
\hline Beryllium & 0.32 & $\mathrm{U}$ & 0.35 & $\mathrm{U}$ & 0.34 & $\mathrm{U}$ \\
\hline Cadmium & 0.19 & $\mathrm{U}$ & 0.20 & $\mathrm{U}$ & 0.19 & $\mathrm{U}$ \\
\hline Calcium & 7890.00 & & 11000.00 & $\mathrm{~J}$ & 9920.00 & $\mathbf{J}$ \\
\hline Chromium & 7.60 & & 17.50 & $\mathrm{~J}$ & 19.00 & $\mathrm{~J}$ \\
\hline Cobalt & 6.90 & & 7.70 & & 7.10 & \\
\hline Copper & 13.60 & & 18.40 & & 15.80 & \\
\hline Cyanide & 4.70 & $U$ & 0.52 & U & 0.50 & $\mathrm{U}$ \\
\hline Iron & 12800.00 & & 14700.00 & & 12600.00 & \\
\hline Lead & 2.90 & $\mathrm{~J}$ & 4.00 & & 3.30 & \\
\hline Magnesium & 3330.00 & & 4720.00 & $\mathrm{~J}$ & 4530.00 & $\mathrm{~J}$ \\
\hline Manganese & 211.00 & & 246.00 & $\mathrm{~J}$ & 212.00 & $\mathrm{~J}$ \\
\hline Mercury & 0.09 & $\mathrm{U}$ & 0.09 & $\mathrm{U}$ & 0.09 & $\mathrm{U}$ \\
\hline Nickel & 7.40 & & 19.20 & $\mathrm{~J}$ & 24.40 & $\mathrm{~J}$ \\
\hline Potassium & 766.00 & & 916.00 & & 749.00 & \\
\hline Selenium & 0.78 & $U$ & 3.90 & $\mathrm{U}$ & 4.00 & $\mathrm{U}$ \\
\hline Silver & 0.39 & $\mathrm{U}$ & 0.39 & $U$ & 0.39 & $\mathrm{U}$ \\
\hline Sodium & 277.00 & & 229.00 & & 193.00 & \\
\hline Thallium & 0.58 & $U$ & 0.79 & $\mathrm{U}$ & 0.79 & $\mathrm{U}$ \\
\hline Vanadium & 32.20 & & 34.60 & & 30.40 & \\
\hline Zinc & 31.70 & & 35.70 & & 30.90 & \\
\hline \multicolumn{7}{|l|}{ Organic Analysis $^{\circ}$} \\
\hline 1,1,1-Trichloroethane & 5 & $\mathrm{U}$ & 5 & $\mathrm{U}$ & 5 & $\mathrm{U}$ \\
\hline 1,1,2,2-Tetrachloroethane & 5 & $\mathrm{U}$ & 5 & $\mathrm{U}$ & 5 & $\mathrm{U}$ \\
\hline 1,1,2-Trichloroethane & 5 & $\mathrm{U}$ & 5 & $\mathrm{U}$ & 5 & $\mathrm{U}$ \\
\hline
\end{tabular}

Refer to footnotes at end of table. 
DOE/RL-93-51, Rev. 0

Table A-2 Chemical Analysis Resuits for Borehole 116-H-2 (page 2 of 6)

\begin{tabular}{|c|c|c|c|c|c|c|}
\hline \multirow[b]{3}{*}{ Analyte } & \multicolumn{6}{|c|}{ SAMPLE NUMBERS } \\
\hline & \multicolumn{2}{|l|}{ B05WW5 } & \multicolumn{2}{|l|}{ B05WW6 } & \multicolumn{2}{|l|}{ B05WW7" } \\
\hline & $\begin{array}{l}\text { top: } 9.9 \mathrm{ft} \\
\text { bottom: } 12.1 \mathrm{ft}\end{array}$ & Q & $\begin{array}{l}\text { top: } 14.9 \mathrm{ft} \\
\text { bottom: } 17.2 \mathrm{ft}\end{array}$ & $Q$ & $\begin{array}{l}\text { top: } 14.9 \mathrm{ft} \\
\text { bottom: } 17.2 \mathrm{ft}\end{array}$ & $Q$ \\
\hline 1,1-Dichloroethane & 5 & $\mathrm{U}$ & 5 & $U$ & 5 & $\mathbf{U}$ \\
\hline 1,1-Dichloroethene & 5 & $\mathrm{U}$ & 5 & $\mathrm{U}$ & 5 & $\mathbf{U}$ \\
\hline 1,2-Dichloroethane & 5 & $\mathrm{U}$ & 5 & $\mathrm{U}$ & 5 & $\mathrm{U}$ \\
\hline 1,2-Dichloroethene & 5 & $\mathrm{U}$ & 5 & $\mathrm{U}$ & 5 & $\mathbf{U}$ \\
\hline 1,2-Dichloropropane & 5 & $\mathrm{U}$ & 5 & $U$ & 5 & $\mathbf{U}$ \\
\hline 2-Butanone & 10 & $\mathrm{U}$ & 10 & $\mathrm{U}$ & 10 & $\mathrm{U}$ \\
\hline 2-Hexanone & 10 & $\mathrm{U}$ & 10 & $\mathrm{U}$ & 10 & $\mathrm{U}$ \\
\hline 4-Methyl-2-pentanone & 10 & $\mathrm{U}$ & 10 & $\mathrm{U}$ & 10 & $\mathrm{U}$ \\
\hline Acetone & 14 & $\mathrm{U}$ & 78 & $\mathrm{U}$ & 120 & U \\
\hline Benzene & 5 & $\mathrm{U}$ & 5 & $\mathrm{U}$ & 5 & $\mathrm{U}$ \\
\hline Bromodichloromethane & 5 & $\mathbf{U}$ & 5 & $\mathrm{U}$ & 5 & $\mathrm{U}$ \\
\hline Bromoform & 5 & $\mathrm{U}$ & 5 & $\mathbf{U}$ & 5 & $U$ \\
\hline Bromomethane & 10 & $\mathrm{U}$ & 10 & $\mathrm{U}$ & 10 & $\mathrm{U}$ \\
\hline Carbon disulfide & 5 & $\mathrm{U}$ & 5 & $\mathrm{U}$ & 5 & $U$ \\
\hline Carbon tetrachloride & 5 & $\mathrm{U}$ & 5 & $\mathrm{U}$ & 5 & $U$ \\
\hline Chlorobenzene & 5 & $\mathrm{U}$ & 5 & $\mathrm{U}$ & 5 & $\mathrm{U}$ \\
\hline Chloroethane & 10 & $\mathrm{U}$ & 10 & $\mathrm{U}$ & 10 & $U$ \\
\hline Chloroform & 5 & $\mathrm{U}$ & 5 & $\mathrm{U}$ & 5 & $\mathrm{U}$ \\
\hline Chloromethane & 10 & $\mathrm{U}$ & 10 & $\mathrm{U}$ & 10 & $\mathrm{U}$ \\
\hline Dibromochloromethane & 5 & $\mathrm{U}$ & 5 & $\mathrm{U}$ & 5 & $\mathrm{U}$ \\
\hline Ethylbenzene & 5 & $\mathrm{U}$ & 5 & $\mathrm{U}$ & 5 & $\mathrm{U}$ \\
\hline Methylene chloride & 10 & $\mathrm{U}$ & 5 & $\mathrm{U}$ & 3 & $\mathrm{~J}$ \\
\hline Styrene & 5 & $\mathrm{U}$ & 5 & $\mathrm{U}$ & 5 & $\mathrm{U}$ \\
\hline Tetrachloroethene & 5 & $\mathrm{U}$ & 5 & $\mathrm{U}$ & 5 & $\mathrm{U}$ \\
\hline Toluene & 5 & $\mathrm{U}$ & 5 & $\mathrm{U}$ & 2 & $\mathrm{U}$ \\
\hline Trichloroethene & 5 & $\mathrm{U}$ & 5 & $\mathrm{U}$ & 5 & $U$ \\
\hline Vinyl acetate & 10 & $\mathrm{U}$ & 10 & $\mathrm{U}$ & 10 & $\mathrm{U}$ \\
\hline Vinyl chloride & 10 & $\mathrm{U}$ & 10 & $\mathrm{U}$ & 10 & $\mathrm{U}$ \\
\hline Xylenes (total) & 5 & $\mathrm{U}$ & 5 & $\mathrm{U}$ & 5 & $\mathrm{U}$ \\
\hline
\end{tabular}

Refer to footnotes at end of table. 
DOE/RL-93-51, Rev. 0

Table A-2 Chemical Analysis Results for Borehole 116-H-2 (page 3 of 6 )

\begin{tabular}{|c|c|c|c|c|c|c|}
\hline \multirow[b]{3}{*}{ Analyte } & \multicolumn{6}{|c|}{ SAMPLE NUMBERS } \\
\hline & \multicolumn{2}{|l|}{ B05WW5 } & \multicolumn{2}{|l|}{ B05WW6 } & \multicolumn{2}{|l|}{$\mathrm{B} 05 \mathrm{WW} 7^{\mathrm{a}}$} \\
\hline & $\begin{array}{l}\text { top: } 9.9 \mathrm{ft} \\
\text { bottom: } 12.1 \mathrm{ft} \\
\end{array}$ & $\mathrm{Q}$ & $\begin{array}{l}\text { top: } 14.9 \mathrm{ft} \\
\text { bottom: } 17.2 \mathrm{ft} \\
\end{array}$ & $Q$ & $\begin{array}{l}\text { top: } 14.9 \mathrm{ft} \\
\text { bottom: } 17.2 \mathrm{ft} \\
\end{array}$ & $Q$ \\
\hline cis-1,3-Dichloropropene & 5 & $U$ & 5 & $\mathrm{U}$ & 5 & $\mathbf{U}$ \\
\hline trans-1,3-Dichloropropene & 5 & $\mathrm{U}$ & 5 & $\mathrm{U}$ & 5 & $\bar{U}$ \\
\hline \multicolumn{7}{|c|}{ Semivolatile Organic Analysis ${ }^{c}$} \\
\hline 1,2,4-Trichlorobenzene & 340 & $\mathrm{U}$ & 340 & $\mathrm{U}$ & 340 & $\mathbf{U}$ \\
\hline 1,2-Dichlorobenzene & 340 & $\mathrm{U}$ & 340 & $\mathrm{U}$ & 340 & $\mathbf{U}$ \\
\hline 1,3-Dichlorobenzene & 340 & $\mathrm{U}$ & 340 & $\mathrm{U}$ & 340 & $\mathrm{U}$ \\
\hline 1,4-Dichlorobenzene & 340 & $U$ & 340 & $\mathrm{U}$ & 340 & $\mathrm{U}$ \\
\hline 2,4,5-Trichlorophenol & 1600 & $\mathrm{U}$ & 1700 & $\mathrm{U}$ & 1700 & $\mathrm{U}$ \\
\hline 2,4,6-Trichlorophenol & 340 & $\mathrm{U}$ & 340 & $\mathrm{U}$ & 340 & $\mathrm{U}$ \\
\hline 2,4-Dichlorophenol & 340 & $\mathrm{U}$ & 340 & $\mathrm{U}$ & 340 & $\mathrm{U}$ \\
\hline 2,4-Dimethylphenol & 340 & $\mathrm{U}$ & 340 & $\mathrm{U}$ & 340 & $\mathrm{U}$ \\
\hline 2,4-Dinitrophenol & 1600 & $\mathrm{U}$ & 1700 & $\mathrm{U}$ & 1700 & $\mathbf{U}$ \\
\hline 2,4-Dinitrotoluene & 340 & $\mathrm{U}$ & 340 & $\mathrm{U}$ & 340 & $\mathrm{U}$ \\
\hline 2,6-Dinitrotoluene & 340 & $\mathrm{U}$ & 340 & $\mathrm{U}$ & 340 & $\mathrm{U}$ \\
\hline 2-Chloronaphthalene & 340 & $\mathrm{U}$ & 340 & $\mathrm{U}$ & 340 & $\mathrm{U}$ \\
\hline 2-Chlorophenol & 340 & $\mathrm{U}$ & 340 & $\mathrm{U}$ & 340 & $\mathrm{U}$ \\
\hline 2-Methylnaphthalene & 340 & $\mathrm{U}$ & 340 & $\mathrm{U}$ & 340 & $\mathrm{U}$ \\
\hline 2-Methylphenol & 340 & $\mathrm{U}$ & 340 & $\mathrm{U}$ & 340 & $\mathrm{U}$ \\
\hline 2-Nitroaniline & 1600 & $\mathrm{U}$ & 1700 & $\mathrm{U}$ & 1700 & $\mathrm{U}$ \\
\hline 2-Nitrophenol & 340 & $\mathrm{U}$ & 340 & $\mathrm{U}$ & 340 & $\mathrm{U}$ \\
\hline 3-Nitroaniline & 1600 & $\mathrm{U}$ & 1700 & $\mathrm{U}$ & 1700 & $\mathrm{U}$ \\
\hline 3,3-Dichlorbenzidine & 680 & $\mathrm{U}$ & 690 & $\mathrm{U}$ & 690 & $\mathrm{U}$ \\
\hline 4,6-Dinitro-2-methyl phenol & 1600 & $\mathbf{U}$ & 1700 & $\mathrm{U}$ & 1700 & $\mathrm{U}$ \\
\hline 4-Bromophenylphenyl ether & 340 & $\mathrm{U}$ & 340 & $\mathrm{U}$ & 340 & $\mathrm{U}$ \\
\hline 4-Chloro-3-methylphenol & 340 & $\mathrm{U}$ & 340 & $\mathrm{U}$ & 340 & $\mathrm{U}$ \\
\hline 4-Chlorophenylphenyl ether & 340 & $\mathrm{U}$ & 340 & $\mathrm{U}$ & 340 & $\mathrm{U}$ \\
\hline 4-Chloroaniline & 340 & $\mathrm{U}$ & 340 & $\mathrm{U}$ & 340 & $\mathrm{U}$ \\
\hline 4-Methylphenol & 340 & $\mathrm{U}$ & 340 & $\mathrm{U}$ & 340 & $\mathrm{U}$ \\
\hline 4-Nitroaniline & 1600 & $\mathrm{U}$ & 1700 & $\mathrm{U}$ & 1700 & $\mathrm{U}$ \\
\hline
\end{tabular}

Refer to footnotes at ond of table. 
DOE/RL-93-51, Rev. 0

Table A-2 Chemical Analysis Results for Borehole 116-H-2 (page 4 of 0 )

\begin{tabular}{|c|c|c|c|c|c|c|}
\hline \multirow[b]{3}{*}{ Analyte } & \multicolumn{6}{|c|}{ SAMPLE NUMBERS } \\
\hline & \multicolumn{2}{|l|}{ B05WW5 } & \multicolumn{2}{|l|}{ B05WW6 } & \multicolumn{2}{|l|}{$B 05 W W 7^{\circ}$} \\
\hline & $\begin{array}{l}\text { top: } 9.9 \mathrm{ft} \\
\text { bottom: } 12.1 \mathrm{ft}\end{array}$ & Q & $\begin{array}{l}\text { top: } 14.9 \mathrm{ft} \\
\text { bottom: } 17.2 \mathrm{ft}\end{array}$ & $Q$ & $\begin{array}{l}\text { top: } 14.9 \mathrm{ft} \\
\text { bottom: } 17.2 \mathrm{ft}\end{array}$ & Q \\
\hline 4-Nitrophenol & 1600 & $\mathrm{U}$ & 1700 & $\mathrm{U}$ & 1700 & $\mathbf{U}$ \\
\hline Acenaphthene & 340 & $\mathrm{U}$ & 340 & $\mathrm{U}$ & 340 & $\mathrm{U}$ \\
\hline Acenaphthylene & 340 & $\mathrm{U}$ & 340 & $\mathrm{U}$ & 340 & $\mathrm{U}$ \\
\hline Anthracene & 340 & $\mathbf{U}$ & 340 & $\mathrm{U}$ & 340 & $\mathrm{U}$ \\
\hline Benzo(a)anthracene & 340 & $\mathrm{U}$ & 340 & $\mathbf{U}$ & 340 & $\mathbf{U}$ \\
\hline Benzo(a)pyrene & 340 & $\mathrm{U}$ & 340 & $\mathrm{U}$ & 340 & $\mathbf{U}$ \\
\hline Benzo(b)fluoranthene & 340 & $\mathrm{U}$ & 340 & $\mathrm{U}$ & 340 & $\mathbf{U}$ \\
\hline Benzo(ghi)perylene & 340 & $\mathrm{U}$ & 340 & $\mathrm{U}$ & 340 & $\mathrm{U}$ \\
\hline Benzo(k)fluoranthene & 340 & $\mathbf{U}$ & 340 & $\mathrm{U}$ & 340 & $\mathrm{U}$ \\
\hline Benzoic acid & 1600 & $\mathrm{U}$ & 1700 & $\mathrm{U}$ & 1700 & $\mathrm{U}$ \\
\hline Benzyl alcohol & 340 & $\mathrm{U}$ & 340 & $\mathbf{U}$ & 340 & $\mathbf{U}$ \\
\hline Bis(2-chloroethoxy)methane & 340 & U & 340 & $\mathrm{U}$ & 340 & $\mathbf{U}$ \\
\hline Bis(2-chloroethyl)ether & 340 & $\mathrm{U}$ & 340 & $\mathrm{U}$ & 340 & $\mathbf{U}$ \\
\hline Bis(2-chloroisopropyl)ether & 340 & $\mathbf{U}$ & 340 & $\mathrm{U}$ & 340 & $\mathbf{U}$ \\
\hline Bis(2-ethylhexyl)phthalate & 340 & $\mathrm{U}$ & 340 & $\mathrm{U}$ & 340 & $\mathbf{U}$ \\
\hline Butylbenzylphthalate & 340 & $\mathbf{U}$ & 340 & $\mathrm{U}$ & 340 & $\mathbf{U}$ \\
\hline Chrysene & 340 & $\mathrm{U}$ & 340 & $\mathrm{U}$ & 340 & $\mathbf{U}$ \\
\hline Di-n-butylphthalate & 48 & $\mathrm{~J}$ & 340 & $\mathrm{U}$ & 340 & $\mathrm{U}$ \\
\hline Di-n-octylphthalate & 340 & $\mathbf{U}$ & 340 & $\mathrm{U}$ & 340 & U \\
\hline Dibenz[a,h]anthracene & 340 & $\mathrm{U}$ & 340 & $U$ & 340 & $\mathrm{U}$ \\
\hline Dibenzofuran & 340 & $\mathrm{U}$ & 340 & $\mathrm{U}$ & 340 & $\mathbf{U}$ \\
\hline Diethyl phthalate & 340 & $\mathrm{U}$ & 340 & $\mathrm{U}$ & 340 & $\mathbf{U}$ \\
\hline Dimethyl phthalate & 340 & $\mathrm{U}$ & 340 & $\mathrm{U}$ & 340 & $\mathbf{U}$ \\
\hline Fluoranthene & 340 & $\mathrm{U}$ & 340 & $\mathrm{U}$ & 340 & $\mathrm{U}$ \\
\hline Fluorene & 340 & $\mathrm{U}$ & 340 & $\mathrm{U}$ & 340 & $\mathrm{U}$ \\
\hline Hexachlorobenzene & 340 & $\mathrm{U}$ & 340 & $\mathrm{U}$ & 340 & U \\
\hline Hexachlorobutadiene & 340 & $\mathrm{U}$ & 340 & $\mathrm{U}$ & 340 & U \\
\hline Hexachlorocyclopentadiene & 340 & $\mathrm{U}$ & 340 & $\mathrm{U}$ & 340 & $\mathbf{U}$ \\
\hline Hexachloroethane & 340 & $\mathrm{U}$ & 340 & $\mathrm{U}$ & 340 & $\mathrm{U}$ \\
\hline
\end{tabular}

Refer to footnotes at end of table. 
DOE/RL-93-51, Rev. 0

Table A-2 Chemical Analysis Results for Borehole 116-H-2 (page 5 of 6 )

\begin{tabular}{|c|c|c|c|c|c|c|}
\hline \multirow[b]{3}{*}{ Analyte } & \multicolumn{6}{|c|}{ SAMPLE NUMBERS } \\
\hline & \multicolumn{2}{|l|}{ B05WW5 } & \multicolumn{2}{|l|}{ B05WW6 } & \multicolumn{2}{|l|}{ B05WW7" } \\
\hline & $\begin{array}{l}\text { top: } 9.9 \mathrm{ft} \\
\text { bottom: } 12.1 \mathrm{ft}\end{array}$ & $Q$ & $\begin{array}{l}\text { top: } 14.9 \mathrm{ft} \\
\text { bottom: } 17.2 \mathrm{ft}\end{array}$ & $\mathrm{Q}$ & $\begin{array}{l}\text { top: } 14.9 \mathrm{ft} \\
\text { bottom: } 17.2 \mathrm{ft}\end{array}$ & $Q$ \\
\hline Ideno(1,2,3-cd)pyrene & 340 & $\mathrm{U}$ & 340 & $\mathrm{U}$ & 340 & $\mathrm{U}$ \\
\hline Isophorone & 340 & $\mathrm{U}$ & 340 & $\mathrm{U}$ & 340 & $\mathbf{U}$ \\
\hline N-Nitroso-di-n-dipropylamine & 340 & $\mathrm{U}$ & 340 & $\mathrm{U}$ & 340 & $\mathbf{u}$ \\
\hline N-Nitrosodiphenylamine & 340 & $\mathrm{U}$ & 340 & $\mathrm{U}$ & 340 & $\mathbf{u}$ \\
\hline Naphthalene & 340 & $\mathrm{U}$ & 340 & $\mathrm{U}$ & 340 & $\mathbf{u}$ \\
\hline Nitrobenzene & 340 & $\mathrm{U}$ & 340 & U & 340 & $\mathbf{u}$ \\
\hline Pentachlorophenol & 1600 & $\mathrm{U}$ & 1700 & $\mathrm{U}$ & 1700 & $\mathrm{U}$ \\
\hline Phenanthrene & 340 & $\mathrm{U}$ & 340 & $\mathrm{U}$ & 340 & $\mathrm{U}$ \\
\hline Phenol & 340 & $\mathrm{U}$ & 340 & $\mathrm{U}$ & 340 & $\mathrm{U}$ \\
\hline Pyrene & 340 & $\mathrm{U}$ & 340 & $\mathrm{U}$ & 340 & $\mathbf{U}$ \\
\hline \multicolumn{7}{|l|}{ Pesticide Analysis $^{\circ}$} \\
\hline $4,4^{\prime}-\mathrm{DDD}$ & 16 & $\mathrm{U}$ & 16 & $\mathrm{U}$ & 16 & $\mathrm{U}$ \\
\hline $4,4^{\prime}-\mathrm{DDE}$ & 16 & $\mathrm{U}$ & 16 & $\mathrm{U}$ & 16 & $\mathrm{U}$ \\
\hline $4,4^{\prime}-\mathrm{DDT}$ & 16 & $U$ & 16 & $\mathrm{U}$ & 16 & $\mathbf{U}$ \\
\hline Aldrin & 8 & $\mathrm{U}$ & 8 & $\mathrm{U}$ & 8 & $\mathbf{U}$ \\
\hline Alpha-BHC & 8 & $\mathbf{U}$ & 8 & $\mathrm{U}$ & 8 & $\mathbf{U}$ \\
\hline Aroclor-1016 & 82 & $\mathrm{U}$ & 82 & $\mathrm{U}$ & 82 & $\mathrm{U}$ \\
\hline Aroclor-1221 & 82 & $\mathrm{U}$ & 82 & $\mathrm{U}$ & 82 & $\mathbf{U}$ \\
\hline Aroclor-1232 & 82 & $\mathrm{U}$ & 82 & $\mathrm{U}$ & 82 & $\mathrm{U}$ \\
\hline Aroclor-1242 & 82 & $\mathrm{U}$ & 82 & $\mathrm{U}$ & 82 & $\mathrm{U}$ \\
\hline Aroclor-1248 & 82 & $\mathrm{U}$ & 82 & $U$ & 82 & $\mathrm{U}$ \\
\hline Aroclor-1254 & 160 & $\mathrm{U}$ & 160 & $\mathrm{U}$ & 160 & $\mathbf{U}$ \\
\hline Aroclor- 1260 & 160 & $\mathrm{U}$ & 160 & $\mathrm{U}$ & 160 & $\mathrm{U}$ \\
\hline Beta-BHC & 8 & $\mathrm{U}$ & 8 & $\mathrm{U}$ & 8 & $\mathrm{U}$ \\
\hline Delta-BHC & 8 & $\mathrm{U}$ & 8 & $\mathrm{U}$ & 8 & $\mathrm{U}$ \\
\hline Dieldrin & 16 & $\mathrm{U}$ & 16 & $\mathrm{U}$ & 16 & $\mathrm{U}$ \\
\hline Endosulfan I & 8 & $\mathrm{U}$ & 8 & $\mathbf{U}$ & 8 & $\mathrm{U}$ \\
\hline Endosulfan II & 16 & $\mathrm{U}$ & 16 & $\mathbf{U}$ & 16 & $\mathrm{U}$ \\
\hline Endosulfan sulfate & 16 & $\mathrm{U}$ & 16 & $\mathrm{U}$ & 16 & $\mathrm{U}$ \\
\hline
\end{tabular}

Refer to footnotes at end of table. 
DOE/RL-93-51, Rev. 0

Table A-2 Chemical Analysis Results for Borehole 116-H-2 (page 6 of 6 )

\begin{tabular}{|c|c|c|c|c|c|c|}
\hline \multirow[b]{3}{*}{ Analyte } & \multicolumn{6}{|c|}{ SAMPLE NUMBERS } \\
\hline & \multicolumn{2}{|l|}{ B05WW5 } & \multicolumn{2}{|l|}{ B05WW6 } & \multicolumn{2}{|l|}{$\mathrm{B} 05 \mathrm{WW} 7^{\mathrm{a}}$} \\
\hline & $\begin{array}{l}\text { top: } 9.9 \mathrm{ft} \\
\text { bottom: } 12.1 \mathrm{ft}\end{array}$ & $Q$ & $\begin{array}{l}\text { top: } 14.9 \mathrm{ft} \\
\text { bottom: } 17.2 \mathrm{ft}\end{array}$ & $Q$ & $\begin{array}{l}\text { top: } 14.9 \mathrm{ft} \\
\text { bottom: } 17.2 \mathrm{ft}\end{array}$ & $Q$ \\
\hline Endrin & 16 & $\mathrm{U}$ & 16 & $U$ & 16 & $\mathrm{U}$ \\
\hline Endrin ketone & 16 & $\mathrm{U}$ & 16 & $\mathrm{U}$ & 16 & $\mathrm{u}$ \\
\hline Gamma-BHC (Lindane) & 8 & $\mathrm{U}$ & 8 & $\mathrm{U}$ & 8 & $\mathbf{U}$ \\
\hline Heptaclor & 8 & $\mathrm{U}$ & 8 & $\mathrm{U}$ & 8 & $\mathrm{U}$ \\
\hline Heptaclor epoxide & 8 & $\mathrm{U}$ & 8 & $\mathrm{U}$ & 8 & $\mathbf{U}$ \\
\hline Methoxyclor & 82 & $\mathrm{U}$ & 82 & $\mathrm{U}$ & 82 & $\mathbf{U}$ \\
\hline Toxaphene & 160 & $\mathrm{U}$ & 160 & $\mathrm{U}$ & 160 & $\mathrm{U}$ \\
\hline alpha-Chlordane & 82 & $\mathrm{U}$ & 82 & $\mathrm{U}$ & 82 & $\mathbf{U}$ \\
\hline gamma-Chlordane & 82 & $\mathrm{U}$ & 82 & $\mathbf{U}$ & 82 & $\mathbf{U}$ \\
\hline
\end{tabular}

Duplicate of Sample B05WW6

Units in $\mathrm{mg} / \mathrm{kg}$.

Units in $\mu \mathrm{g} / \mathrm{kg}$.

$\mathrm{Q}=$ Laboratory qualifier.

$\mathrm{U}=$ Below dection limit; detection limit reported.

$\mathrm{J}=$ Estimated value - quality control discrepancies occurred.

$\mathrm{B}=$ Detected in laboratory blank. 
DOE/RL-93-51, Rev. 0

Table A-3 Chemical Analysis Results for Borehole 116-H-3 (page 1 of 6 )

\begin{tabular}{|c|c|c|c|c|}
\hline \multirow[b]{3}{*}{ Analyte } & \multicolumn{4}{|c|}{ SAMPLE NUMBERS } \\
\hline & \multicolumn{2}{|l|}{ B05WP1 } & \multicolumn{2}{|l|}{ B05WP5 } \\
\hline & $\begin{array}{l}\text { top: } 14.5 \mathrm{ft} \\
\text { bottom: } 16.3 \mathrm{ft}\end{array}$ & $Q$ & $\begin{array}{l}\text { top: } 19.6 \mathrm{ft} \\
\text { bottom: } 21.7 \mathrm{ft}\end{array}$ & Q \\
\hline \multicolumn{5}{|l|}{ Inorganic Analysis ${ }^{2}$} \\
\hline Aluminum & 5200.00 & & 4280.00 & \\
\hline Antimony & 5.90 & $\mathrm{U}$ & 1.60 & $\mathrm{U}$ \\
\hline Arsenic & 1.30 & $\mathrm{U}$ & 1.10 & B \\
\hline Barium & 42.50 & & 36.70 & $\bar{B}$ \\
\hline Beryllium & 0.22 & $\mathrm{U}$ & 0.52 & B \\
\hline Cadmium & 0.78 & $\mathrm{U}$ & 0.20 & $\mathrm{U}$ \\
\hline Calcium & 4990.00 & $\mathrm{~J}$ & 4700.00 & \\
\hline Chromium & 10.50 & $\mathrm{~J}$ & 10.20 & \\
\hline Cobalt & 9.20 & $\mathrm{~J}$ & 7.00 & B \\
\hline Copper & 12.90 & & 22.50 & \\
\hline Cyanide & 5.10 & $\mathrm{U}$ & 4.80 & $\mathrm{U}$ \\
\hline Iron & 15900.00 & & 13500.00 & \\
\hline Lead & 2.10 & $\mathrm{~J}$ & 8.60 & \\
\hline Magnesium & 3690.00 & & 3320.00 & \\
\hline Manganese & 231.00 & & 214.00 & \\
\hline Mercury & 0.09 & $\mathrm{U}$ & 0.09 & $\mathrm{U}$ \\
\hline Nickel & 9.60 & & 8.90 & \\
\hline Potassium & 739.00 & & 562.00 & $\mathrm{~B}$ \\
\hline Selenium & 3.80 & $\mathrm{U}$ & 0.75 & $\mathrm{U}$ \\
\hline Silver & 0.96 & $\mathrm{U}$ & 0.39 & $\mathrm{U}$ \\
\hline Sodium & 403.00 & & 277.00 & $\mathrm{~B}$ \\
\hline Thallium & 0.38 & $\mathrm{U}$ & 0.57 & $\mathrm{U}$ \\
\hline Vanadium & 47.10 & & 32.10 & \\
\hline Zinc & 39.10 & $\mathrm{~J}$ & 26.20 & \\
\hline \multicolumn{5}{|l|}{ Organic Analysis $^{b}$} \\
\hline 1,1,1-Trichloroethane & 5 & $\mathrm{U}$ & 5 & $\mathrm{U}$ \\
\hline
\end{tabular}


DOE/RL-93-51, Rev. 0

Table A-3 Chemical Analysis Results for Borehole 116-H-3 (page 2 of 6 )

\begin{tabular}{|c|c|c|c|c|}
\hline \multirow[b]{3}{*}{ Analyte } & \multicolumn{4}{|c|}{ SAMPLE NUMBERS } \\
\hline & \multicolumn{2}{|l|}{ B05WP1 } & \multicolumn{2}{|l|}{ B05WP5 } \\
\hline & $\begin{array}{l}\text { top: } 14.5 \mathrm{ft} \\
\text { bottom: } 16.3 \mathrm{ft}\end{array}$ & $Q$ & $\begin{array}{l}\text { top: } 19.6 \mathrm{ft} \\
\text { bottom: } 21.7 \mathrm{ft}\end{array}$ & Q \\
\hline 1,1,2,2-Tetrachloroethane & 5 & $U$ & 5 & $\mathrm{U}$ \\
\hline 1,1,2-Trichloroethane & $\overline{5}$ & $U$ & 5 & $\bar{U}$ \\
\hline 1,1-Dichloroethane & 5 & $\mathrm{U}$ & 5 & $\overline{\mathrm{U}}$ \\
\hline 1,1-Dichloroethene & 5 & $\mathrm{U}$ & 5 & $\overline{\mathrm{U}}$ \\
\hline 1,2-Dichloroethane & 5 & $\mathrm{U}$ & 5 & $\mathrm{U}$ \\
\hline 1,2-Dichloroethene & 5 & $\mathrm{U}$ & 5 & $\mathrm{U}$ \\
\hline 1,2-Dichloropropane & 5 & $\mathrm{U}$ & 5 & $\bar{U}$ \\
\hline 2-Butanone & 10 & $\mathrm{U}$ & 10 & $\bar{U}$ \\
\hline 2-Hexanone & 10 & $\mathrm{U}$ & 10 & $\bar{U}$ \\
\hline 4-Methyl-2-pentanone & 10 & $\mathrm{U}$ & 10 & $\mathrm{U}$ \\
\hline Acetone & 33 & $\mathrm{U}$ & 7 & $\overline{\mathrm{BJ}}$ \\
\hline Benzene & 5 & $\mathrm{U}$ & 5 & $\mathrm{U}$ \\
\hline Bromodichloromethane & 5 & $\mathrm{U}$ & 5 & $\bar{U}$ \\
\hline Bromoform & 5 & $\mathrm{U}$ & 5 & $\mathrm{U}$ \\
\hline Bromomethane & 10 & $\mathrm{U}$ & 10 & $\mathrm{U}$ \\
\hline Carbon disulfide & 5 & $\mathrm{U}$ & 5 & $\bar{U}$ \\
\hline Carbon tetrachloride & 5 & $\mathrm{U}$ & 5 & $\bar{U}$ \\
\hline Chlorobenzene & 5 & $\mathrm{U}$ & 5 & $\bar{U}$ \\
\hline Chloroethane & 10 & $\mathrm{U}$ & 10 & $\mathrm{U}$ \\
\hline Chloroform & 5 & $\mathrm{U}$ & 5 & $\mathrm{U}$ \\
\hline Chloromethane & 10 & $\mathrm{U}$ & 10 & $\mathrm{U}$ \\
\hline Dibromochloromethane & 5 & $\mathrm{U}$ & 5 & $\bar{U}$ \\
\hline Ethylbenzene & 5 & $\mathrm{U}$ & 5 & $\mathrm{U}$ \\
\hline Methylene chloride & 10 & $\mathrm{U}$ & 3 & $\mathrm{BJ}$ \\
\hline Styrene & 5 & $\mathrm{U}$ & 5 & $\overline{\mathrm{U}}$ \\
\hline Tetrachloroethene & 5 & $\mathrm{U}$ & 5 & $\overline{\mathrm{U}}$ \\
\hline Toluene & 2 & $\mathrm{U}$ & 7 & \\
\hline
\end{tabular}


Table A-3 Chemical Analysis Results for Borehole 116-H-3 (page 3 of 6 )

\begin{tabular}{|c|c|c|c|c|}
\hline \multirow[b]{3}{*}{ Analyte } & \multicolumn{4}{|c|}{ SAMPLE NUMBERS } \\
\hline & \multicolumn{2}{|l|}{ B05WP1 } & \multicolumn{2}{|l|}{ B05WP5 } \\
\hline & $\begin{array}{l}\text { top: } 14.5 \mathrm{ft} \\
\text { bottom: } 16.3 \mathrm{ft}\end{array}$ & $Q$ & $\begin{array}{l}\text { top: } 19.6 \mathrm{ft} \\
\text { bottom: } 21.7 \mathrm{ft}\end{array}$ & Q \\
\hline Trichloroethene & 5 & $\mathrm{U}$ & 5 & $\overline{\mathrm{U}}$ \\
\hline Vinyl acetate & 10 & $\mathrm{U}$ & 10 & $\mathrm{U}$ \\
\hline Vinyl chloride & 10 & $\mathrm{U}$ & 10 & $\mathrm{U}$ \\
\hline Xylenes (total) & 5 & $\mathrm{U}$ & 5 & $\mathrm{U}$ \\
\hline cis-1,3-Dichloropropene & 5 & $\mathrm{U}$ & 5 & $\mathrm{U}$ \\
\hline trans-1,3-Dichloropropene & 5 & $\mathrm{U}$ & 5 & $\mathrm{U}$ \\
\hline \multicolumn{5}{|c|}{ Semivolatile Organic Analysis ${ }^{b}$} \\
\hline 1,2,4-Trichlorobenzene & 320 & $\mathrm{U}$ & 340 & $\mathrm{U}$ \\
\hline 1,2-Dichlorobenzene & 320 & $\mathrm{U}$ & 340 & $\mathrm{U}$ \\
\hline 1,3-Dichlorobenzene & 320 & $\mathrm{U}$ & 340 & $\mathrm{U}$ \\
\hline 1,4-Dichlorobenzene & 320 & $\mathrm{U}$ & 340 & $\mathrm{U}$ \\
\hline 2,4,5-Trichlorophenol & 1600 & $\mathrm{U}$ & 1600 & $\mathrm{U}$ \\
\hline 2,4,6-Trichlorophenol & 320 & $\mathrm{U}$ & 340 & $\mathrm{U}$ \\
\hline 2,4-Dichlorophenol & 320 & $\mathrm{U}$ & 340 & $\mathrm{U}$ \\
\hline 2,4-Dimethylphenol & 320 & $\mathrm{U}$ & 340 & $\mathrm{U}$ \\
\hline 2,4-Dinitrophenol & 1600 & $\mathrm{U}$ & 1600 & $\mathrm{U}$ \\
\hline 2,4-Dinitrotoluene & 320 & $\mathrm{U}$ & 340 & $\bar{U}$ \\
\hline 2,6-Dinitrotoluene & 320 & $\mathrm{U}$ & 340 & $\mathrm{U}$ \\
\hline 2-Chloronaphthalene & 320 & $\mathrm{U}$ & 340 & $\bar{U}$ \\
\hline 2-Chlorophenol & 320 & $\mathrm{U}$ & 340 & $\bar{U}$ \\
\hline 2-Methylnaphthalene & 320 & $\mathrm{U}$ & 340 & $\mathrm{U}$ \\
\hline 2-Methylphenol & 320 & $\mathrm{U}$ & 340 & $\mathrm{U}$ \\
\hline 2-Nitroaniline & 1600 & $\mathrm{U}$ & 1600 & $\mathrm{U}$ \\
\hline 2-Nitrophenol & 320 & $\mathrm{U}$ & 340 & $\mathrm{U}$ \\
\hline 3-Nitroaniline & 1600 & $\mathrm{U}$ & 1600 & $\mathrm{U}$ \\
\hline 3,3-Dichlorbenzidine & 650 & $\mathrm{U}$ & 670 & $\underline{U}$ \\
\hline 4,6-Dinitro-2-methyl phenol & 1600 & $\mathrm{U}$ & 1600 & $\mathrm{U}$ \\
\hline
\end{tabular}


DOE/RL-93-51, Rev. 0

Table A-3 Chemical Analysis Results for Borehole 116-H-3 (page 4 of 6 )

\begin{tabular}{|c|c|c|c|c|}
\hline \multirow[b]{3}{*}{ Analyte } & \multicolumn{4}{|c|}{ SAMPLE NUMBERS } \\
\hline & \multicolumn{2}{|l|}{ B05WP1 } & \multicolumn{2}{|l|}{ B05WP5 } \\
\hline & $\begin{array}{l}\text { top: } 14.5 \mathrm{ft} \\
\text { bottom: } 16.3 \mathrm{ft}\end{array}$ & $\mathrm{Q}$ & $\begin{array}{l}\text { top: } 19.6 \mathrm{ft} \\
\text { bottom: } 21.7 \mathrm{ft}\end{array}$ & Q \\
\hline 4-Bromophenylphenyl ether & 320 & $\mathrm{U}$ & 340 & $\mathrm{U}$ \\
\hline 4-Chloro-3-methylphenol & 320 & $\mathrm{U}$ & 340 & $\mathrm{U}$ \\
\hline 4-Chlorophenylphenyl ether & 320 & $\mathrm{U}$ & 340 & $\bar{U}$ \\
\hline 4-Chloroaniline & 320 & $\mathrm{U}$ & 340 & $\mathrm{U}$ \\
\hline 4-Methylphenol & 320 & $\mathrm{U}$ & 340 & $\mathrm{U}$ \\
\hline 4-Nitroaniline & 1600 & $\mathrm{U}$ & 1600 & $\bar{U}$ \\
\hline 4-Nitrophenol & 1600 & $\mathrm{U}$ & 1600 & $\mathrm{U}$ \\
\hline Acenaphene & 320 & $U$ & 340 & $\bar{U}$ \\
\hline Acenaphthylene & 320 & $U$ & 340 & $\mathrm{U}$ \\
\hline Anthracene & 320 & $\mathrm{U}$ & 340 & $\mathrm{U}$ \\
\hline Benzo(a)anthracene & 320 & $\mathrm{U}$ & 340 & $\mathrm{U}$ \\
\hline Benzo(a)pyrene & 320 & $\mathrm{U}$ & 340 & $\bar{U}$ \\
\hline Benzo(b)fluoranthene & 320 & $\mathrm{U}$ & 340 & $\mathrm{U}$ \\
\hline Benzo(ghi)perylene & 320 & $\mathrm{U}$ & 340 & $\mathrm{U}$ \\
\hline Benzo(k)fluoranthene & 320 & $\mathrm{U}$ & 340 & $\mathrm{U}$ \\
\hline Benzoic acid & 1600 & $\mathrm{U}$ & 1600 & $\mathrm{U}$ \\
\hline Benzyl alcohol & 320 & $\mathrm{U}$ & 340 & $\bar{U}$ \\
\hline Bis(2-chloroethoxy)methane & 320 & $\mathrm{U}$ & 340 & $\mathrm{U}$ \\
\hline Bis(2-chloroethyl)ether & 320 & $\mathrm{U}$ & 340 & $\mathrm{U}$ \\
\hline Bis(2-chloroisopropyl)ether & 320 & $\mathrm{U}$ & 340 & $\mathrm{U}$ \\
\hline Bis(2-ethylhexyl)phthalate & 320 & $\mathrm{U}$ & 340 & $\mathrm{U}$ \\
\hline Butylbenzylphthalate & 320 & $\mathrm{U}$ & 340 & $\mathrm{U}$ \\
\hline Chrysene & 320 & $\mathrm{U}$ & 340 & $\mathrm{U}$ \\
\hline Di-n-butylphthalate & 320 & $\mathrm{U}$ & 340 & $\mathrm{U}$ \\
\hline Di-n-octylphthalate & 320 & $\mathrm{U}$ & 340 & $\mathrm{U}$ \\
\hline Dibenz[a,h]anthracene & 320 & $U$ & 340 & $\mathrm{U}$ \\
\hline Dibenzofuran & 320 & $\mathrm{U}$ & 340 & $\mathrm{U}$ \\
\hline
\end{tabular}


DOE/RL-93-51, Rev. 0

Table A-3 Chemical Analysis Results for Borehole 116-H-3 (page 5 of 6 )

\begin{tabular}{|c|c|c|c|c|}
\hline \multirow[b]{3}{*}{ Analyte } & \multicolumn{4}{|c|}{ SAMPLE NUMBERS } \\
\hline & \multicolumn{2}{|l|}{ B05WP1 } & \multicolumn{2}{|l|}{ B05WP5 } \\
\hline & $\begin{array}{l}\text { top: } 14.5 \mathrm{ft} \\
\text { bottom: } 16.3 \mathrm{ft}\end{array}$ & $\mathrm{Q}$ & $\begin{array}{l}\text { top: } 19.6 \mathrm{ft} \\
\text { bottom: } 21.7 \mathrm{ft}\end{array}$ & Q \\
\hline Diethyl phthalate & 320 & $\mathrm{U}$ & 230 & $\mathrm{~J}$ \\
\hline Dimethyl phthalate & 320 & $\mathrm{U}$ & 340 & $\mathrm{U}$ \\
\hline Fluoranthene & 320 & $\mathrm{U}$ & 340 & $\mathrm{U}$ \\
\hline Fluorene & 320 & $\mathrm{U}$ & 340 & $\mathrm{U}$ \\
\hline Hexachlorobenzene & 320 & $\mathrm{U}$ & 340 & $\mathrm{U}$ \\
\hline Hexachlorobutadiene & 320 & $\mathrm{U}$ & 340 & $\mathrm{U}$ \\
\hline Hexachlorocyclopentadiene & 320 & $\mathrm{U}$ & 340 & $\mathrm{U}$ \\
\hline Hexachloroethane & 320 & $\mathrm{U}$ & 340 & $\mathrm{U}$ \\
\hline Ideno(1,2,3-cd)pyrene & 320 & $\mathrm{U}$ & 340 & $\mathrm{U}$ \\
\hline Isophorone & 320 & $\mathrm{U}$ & 340 & $\mathrm{U}$ \\
\hline N-Nitroso-di-n-dipropylamine & 320 & $\mathrm{U}$ & 340 & $\mathrm{U}$ \\
\hline N-Nitrosodiphenylamine & 320 & $\mathrm{U}$ & 340 & $\mathrm{U}$ \\
\hline Naphthalene & 320 & $\mathrm{U}$ & 340 & $\mathrm{U}$ \\
\hline Nitrobenzene & 320 & $\mathrm{U}$ & 340 & $\mathrm{U}$ \\
\hline Pentachlorophenol & 1600 & $\mathrm{U}$ & 1600 & $\mathrm{U}$ \\
\hline Phenanthrene & 320 & $\mathrm{U}$ & 340 & $\mathrm{U}$ \\
\hline Phenol & 320 & $\mathrm{U}$ & 340 & $\mathrm{U}$ \\
\hline Pyrene & 320 & $\mathrm{U}$ & 340 & $\mathrm{U}$ \\
\hline \multicolumn{5}{|l|}{ Pesticides $^{b}$} \\
\hline $4,4^{\prime}-\mathrm{DDD}$ & 16 & $\mathrm{U}$ & 16 & $\mathrm{U}$ \\
\hline $4,4^{\prime}-\mathrm{DDE}$ & 16 & $\mathrm{U}$ & 16 & $\mathrm{U}$ \\
\hline $4,4^{\prime}-\mathrm{DDT}$ & 16 & $\mathrm{U}$ & 16 & $\mathrm{U}$ \\
\hline Aldrin & 7 & $\mathrm{U}$ & 8 & $\mathrm{U}$ \\
\hline Alpha-BHC & 7 & $\mathrm{U}$ & 8 & $\mathrm{U}$ \\
\hline Aroclor-1016 & 79 & $\mathrm{U}$ & 80 & $\mathrm{U}$ \\
\hline Aroclor -1221 & 79 & $\mathrm{U}$ & 80 & $\mathrm{U}$ \\
\hline Aroclor- 1232 & 79 & $\mathrm{U}$ & 80 & $\mathrm{U}$ \\
\hline
\end{tabular}

Refer to footnotes at end of table. 
DOE/RL-93-51, Rev. 0

Table A-3 Chemical Analysis Results for Borehole 116-H-3 (page 6 of 6 )

\begin{tabular}{|c|c|c|c|c|}
\hline \multirow[b]{3}{*}{ Analyte } & \multicolumn{4}{|c|}{ SAMPLE NUMBERS } \\
\hline & \multicolumn{2}{|l|}{ B05WP1 } & \multicolumn{2}{|l|}{ B05WP5 } \\
\hline & $\begin{array}{l}\text { top: } 14.5 \mathrm{ft} \\
\text { bottom: } 16.3 \mathrm{ft}\end{array}$ & $Q$ & \begin{tabular}{|l|l} 
top: $19.6 \mathrm{ft}$ \\
bottom: $21.7 \mathrm{ft}$ \\
\end{tabular} & Q \\
\hline Aroclor-1242 & 79 & $\mathrm{U}$ & 80 & $\mathrm{U}$ \\
\hline Aroclor-1248 & 79 & $\mathrm{U}$ & 80 & $\mathbf{U}$ \\
\hline Aroclor-1254 & 160 & $\mathrm{U}$ & 160 & $\bar{U}$ \\
\hline Aroclor -1260 & 160 & $\mathrm{U}$ & 160 & $\mathrm{U}$ \\
\hline Beta-BHC & 7 & $\mathrm{U}$ & 8 & $\mathrm{U}$ \\
\hline Delta-BHC & 7 & $\mathrm{U}$ & 8 & $\mathrm{U}$ \\
\hline Dieldrin & 16 & $\mathrm{U}$ & 16 & $\bar{U}$ \\
\hline Endosulfan I & 7 & $\mathrm{U}$ & 8 & $\mathrm{U}$ \\
\hline Endosulfan II & 16 & $\mathrm{U}$ & 16 & $\mathrm{U}$ \\
\hline Endosulfan sulfate & 16 & $\mathrm{U}$ & 16 & $\mathrm{U}$ \\
\hline Endrin & 16 & $\mathrm{U}$ & 16 & $\mathrm{U}$ \\
\hline Endrin ketone & 16 & $\mathrm{U}$ & 16 & $\bar{U}$ \\
\hline Gamma-BHC (Lindane) & 7 & $\mathrm{U}$ & 8 & U \\
\hline Heptaclor & 7 & $\mathrm{U}$ & 8 & $\mathrm{U}$ \\
\hline Heptaclor epoxide & 7 & $\mathrm{U}$ & 8 & $\mathrm{U}$ \\
\hline Methoxyclor & 79 & $\mathrm{U}$ & 80 & $\mathrm{U}$ \\
\hline Toxaphene & 160 & $\mathrm{U}$ & 160 & $\mathrm{U}$ \\
\hline alpha-Chlordane & 79 & $\mathrm{U}$ & 80 & $\mathrm{U}$ \\
\hline gamma-Chlordane & 79 & $\mathrm{U}$ & 80 & $\mathrm{U}$ \\
\hline
\end{tabular}

${ }^{a}$ Units in $\mathrm{mg} / \mathrm{kg}$.

bUnits in $\mu \mathrm{g} / \mathrm{kg}$.

$\mathrm{Q}=$ Laboratory qualifier.

$\mathrm{U}=$ Below dection limit; detection limit reported.

$\mathrm{J}=$ Estimated value-quality control discrepancies occurred.

$\mathrm{B}=$ Detected in laboratory blank. 


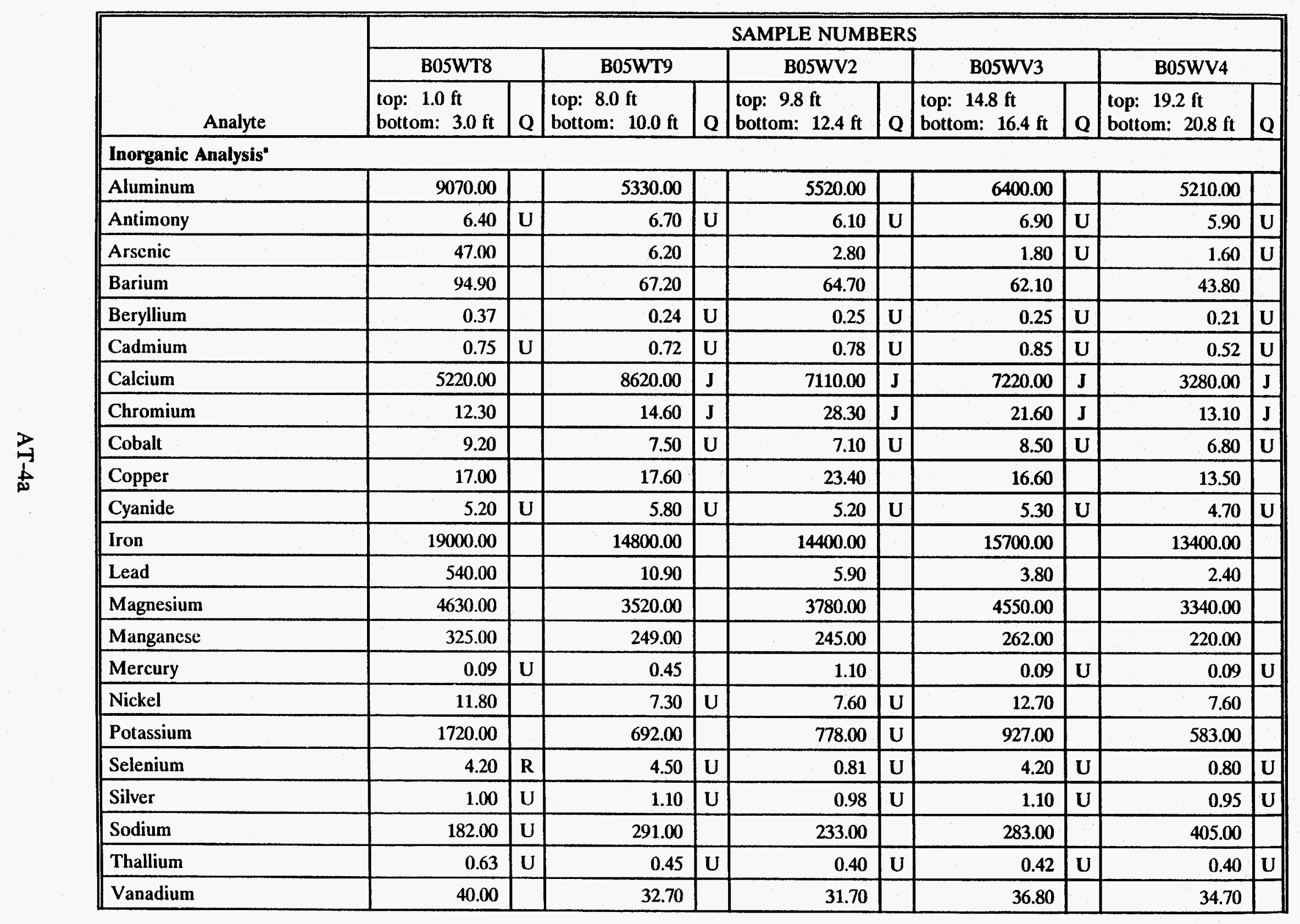




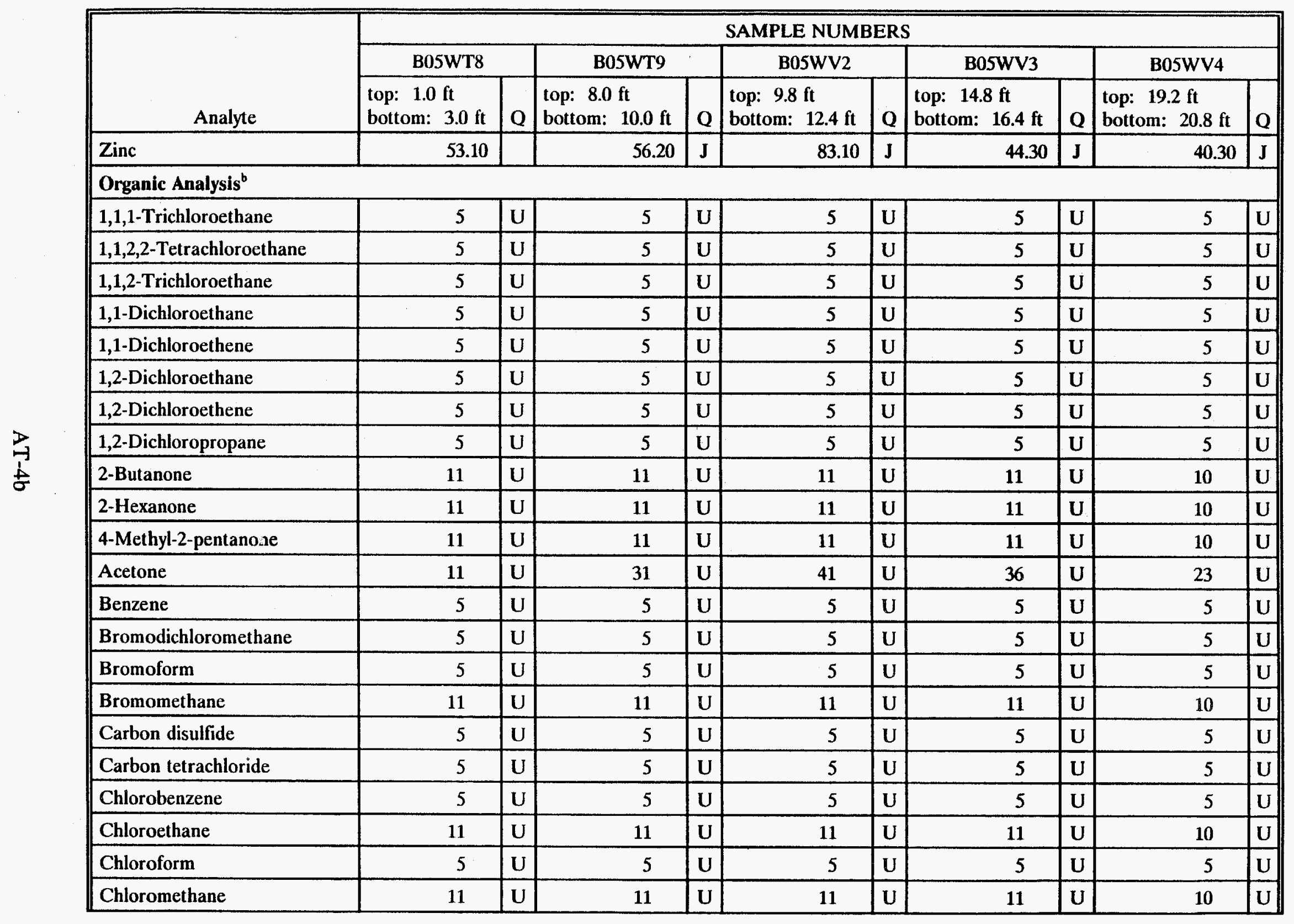




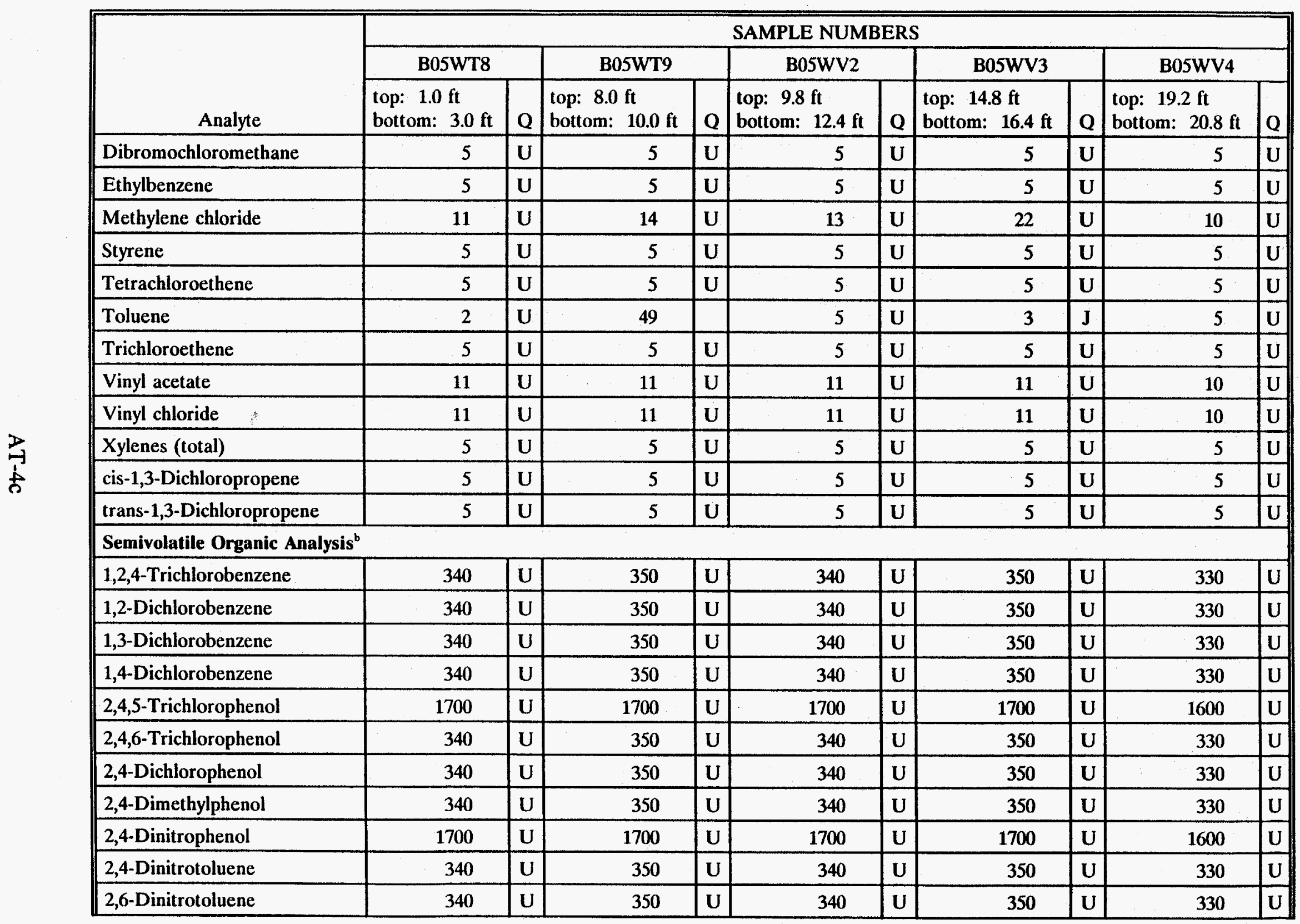




\begin{tabular}{|c|c|c|c|c|c|c|c|c|c|c|}
\hline \multirow[b]{3}{*}{ Analyte } & \multicolumn{10}{|c|}{ SAMPLE NUMBERS } \\
\hline & \multicolumn{2}{|l|}{ B05WT8 } & \multicolumn{2}{|l|}{ B05WT9 } & \multicolumn{2}{|l|}{ B05WV2 } & \multicolumn{2}{|l|}{ B05WV3 } & \multicolumn{2}{|l|}{ B05WV4 } \\
\hline & $\begin{array}{l}\text { top: } 1.0 \mathrm{ft} \\
\text { bottom: } 3.0 \mathrm{ft}\end{array}$ & $\mathbf{Q}$ & $\begin{array}{l}\text { top: } 8.0 \mathrm{ft} \\
\text { bottom: } 10.0 \mathrm{ft}\end{array}$ & $\mathbf{Q}$ & $\begin{array}{l}\text { top: } 9.8 \mathrm{ft} \\
\text { bottom: } 12.4 \mathrm{ft} \\
\end{array}$ & $\mathbf{Q}$ & $\begin{array}{l}\text { top: } 14.8 \mathrm{ft} \\
\text { bottom: } 16.4 \mathrm{ft}\end{array}$ & $\mathbf{Q}$ & $\begin{array}{l}\text { top: } 19.2 \mathrm{ft} \\
\text { bottom: } 20.8 \mathrm{ft}\end{array}$ & $\mathbf{Q}$ \\
\hline 2-Chloronaphthalene & 340 & $\mathbf{U}$ & 350 & $\mathbf{U}$ & 340 & $\mathbf{U}$ & 350 & $\mathbf{U}$ & 330 & $\mathbf{u}$ \\
\hline 2-Chlorophenol & 340 & $\mathbf{U}$ & 350 & $\mathbf{U}$ & 340 & $\mathbf{U}$ & 350 & $\mathbf{U}$ & 330 & $\mathbf{U}$ \\
\hline Methylnaphthalene & 340 & $\mathrm{U}$ & 350 & $\mathbf{U}$ & 340 & $\mathbf{U}$ & 350 & $\mathbf{U}$ & 330 & $\mathbf{U}$ \\
\hline 2-Methylphenol & 340 & $\mathbf{U}$ & 350 & $\mathbf{U}$ & 340 & $\mathbf{U}$ & 350 & $\mathbf{U}$ & 330 & $\mathbf{u}$ \\
\hline 2-Nitroaniline & 1700 & $\mathrm{U}$ & 1700 & $\mathbf{U}$ & 1700 & $\mathbf{U}$ & 1700 & $\mathbf{U}$ & 1600 & $\mathbf{U}$ \\
\hline 2-Nitrophenol & 340 & $\mathrm{U}$ & 350 & $\mathbf{U}$ & 340 & $\mathbf{U}$ & 350 & $\mathbf{U}$ & 330 & $\mathbf{U}$ \\
\hline 3-Nitroaniline & 1700 & $\mathrm{U}$ & 1700 & $\mathbf{U}$ & 1700 & $\mathbf{U}$ & 1700 & $\mathbf{U}$ & 1600 & $\mathbf{U}$ \\
\hline 3,3-Dichlorbenzidine & 690 & $\mathrm{U}$ & 690 & $\mathbf{U}$ & 690 & $\mathbf{U}$ & 700 & $\mathbf{U}$ & 660 & $\mathbf{U}$ \\
\hline 4,6-Dinitro-2-methyl phenol & 1700 & $\mathrm{U}$ & 1700 & $\mathbf{U}$ & 1700 & $\mathbf{U}$ & 1700 & $\mathbf{U}$ & 1600 & $\mathbf{U}$ \\
\hline 4-Bromophenylphenyl ether & 340 & $\mathrm{U}$ & 350 & $\mathbf{U}$ & 340 & $\mathbf{U}$ & 350 & $\mathbf{U}$ & 330 & $\mathbf{U}$ \\
\hline 4-Chloro-3-methylphenol & 340 & $\mathrm{U}$ & 350 & $\mathbf{U}$ & 340 & $\mathbf{u}$ & 350 & $\mathbf{U}$ & 330 & $\mathbf{U}$ \\
\hline 4-Chlorophenylphenyl ether & 340 & $\mathbf{U}$ & 350 & $\mathbf{U}$ & 340 & $\mathbf{U}$ & 350 & $\mathbf{U}$ & 330 & $\mathbf{u}$ \\
\hline 4-Chloroaniline & 340 & $\mathrm{U}$ & 350 & $\mathbf{U}$ & 340 & $\mathbf{U}$ & 350 & $\mathbf{U}$ & 330 & $\mathbf{U}$ \\
\hline 4-Methylphenol & 340 & $\mathrm{U}$ & 350 & $\mathbf{U}$ & 340 & $\mathrm{U}$ & 350 & $\mathbf{U}$ & 330 & $\mathbf{U}$ \\
\hline 4-Nitroaniline & 1700 & $\mathrm{U}$ & 1700 & $\mathbf{U}$ & 1700 & $\mathbf{U}$ & 1700 & $\mathbf{U}$ & 330 & $\mathbf{U}$ \\
\hline 4-Nitrophenol & 1700 & $\mathrm{U}$ & 1700 & $\mathbf{U}$ & 1700 & $\mathbf{U}$ & 1700 & $\mathbf{U}$ & 1600 & $\mathbf{U}$ \\
\hline Acenaphthene & 340 & $\mathrm{U}$ & 350 & $\mathbf{U}$ & 340 & $\mathbf{U}$ & 350 & $\mathbf{U}$ & 330 & $\mathbf{U}$ \\
\hline Acenaphthylene & 340 & $\mathrm{U}$ & 350 & $\mathbf{U}$ & 340 & $\mathrm{U}$ & 350 & $\mathbf{U}$ & 330 & $\mathbf{U}$ \\
\hline Anthracene & 340 & $\mathbf{U}$ & 350 & $\mathbf{U}$ & 340 & $\mathbf{U}$ & 350 & $\mathbf{U}$ & 330 & $\mathbf{U}$ \\
\hline Benzo(a)anthracene & 340 & $\mathbf{U}$ & 350 & $\mathbf{U}$ & 340 & $\mathbf{U}$ & 350 & $\mathbf{U}$ & 330 & $\mathbf{U}$ \\
\hline Benzo(a)pyrene & 340 & $\mathrm{U}$ & 350 & $\mathbf{U}$ & 340 & $\mathbf{U}$ & 350 & $\mathbf{U}$ & 330 & $\mathbf{U}$ \\
\hline Benzo(b)fluoranthene & 340 & $\mathrm{U}$ & 350 & $\mathbf{U}$ & 340 & $\mathbf{U}$ & 350 & $\mathbf{U}$ & 330 & $\mathbf{U}$ \\
\hline Benzo(ghi)perylene & 340 & $\mathrm{U}$ & 350 & $\mathbf{U}$ & 340 & $\mathbf{U}$ & 350 & $\mathbf{U}$ & 330 & $\mathbf{U}$ \\
\hline Benzo(k)fluoranthene & 340 & $\mathbf{u}$ & 350 & $\mathbf{U}$ & 340 & $\mathbf{U}$ & 350 & $\mathbf{U}$ & 330 & $\mathbf{U}$ \\
\hline
\end{tabular}


SAMPLE NUMBERS

Analyte

\begin{tabular}{l|l} 
B05WT9 & B05WV2
\end{tabular}

B05WV3

B05WV4

\begin{tabular}{l|l|l|l|l|l|l} 
top: $1.0 \mathrm{ft}$ & top: $8.0 \mathrm{ft}$ & top: $9.8 \mathrm{ft}$ & top: $14.8 \mathrm{ft}$ & top: $19.2 \mathrm{ft}$
\end{tabular}

\begin{tabular}{|c|c|c|c|c|c|c|c|c|c|c|}
\hline Analyte & bottom: $3.0 \mathrm{ft}$ & $\mathbf{Q}$ & bottom: $10.0 \mathrm{ft}$ & $\mathbf{Q}$ & bottom: $12.4 \mathrm{ft}$ & $\mathbf{Q}$ & bottom: $16.4 \mathrm{ft}$ & $\mathbf{Q}$ & bottom: $20.8 \mathrm{ft}$ & $\mathbf{Q}$ \\
\hline Benzoic acid & 1700 & $\mathbf{U}$ & 1700 & $\mathbf{U}$ & 1700 & $\mathbf{U}$ & 1700 & $\mathbf{U}$ & 330 & $\mathbf{U}$ \\
\hline Benzyl alcohol & 340 & $\mathbf{U}$ & 350 & $\mathbf{U}$ & 340 & $\mathbf{U}$ & 350 & $\mathbf{u}$ & 330 & $\mathbf{U}$ \\
\hline Bis(2-chloroethoxy)methane & 340 & $\mathbf{U}$ & 350 & $\mathbf{U}$ & 340 & $\mathbf{U}$ & 350 & $\mathbf{U}$ & 330 & $\mathbf{U}$ \\
\hline Bis(2-chloroethyl)ether & 340 & $\mathbf{U}$ & 350 & $\mathbf{U}$ & 340 & $\mathbf{U}$ & 350 & $\mathbf{U}$ & 330 & $\mathbf{U}$ \\
\hline Bis(2-chloroisopropyl)ether & 340 & $\mathbf{U}$ & 350 & $\mathbf{U}$ & 340 & $\mathbf{U}$ & 350 & $\mathbf{U}$ & 330 & $\mathbf{U}$ \\
\hline Bis(2-ethylhexyl)phthalate & 340 & $\mathbf{U}$ & 350 & $\mathbf{U}$ & 340 & $\mathbf{U}$ & 350 & $\mathbf{U}$ & 330 & $\mathbf{U}$ \\
\hline Butylbenzylphthalate & 340 & $\mathbf{U}$ & 350 & $\mathbf{U}$ & 340 & $\mathbf{u}$ & 350 & $\mathbf{U}$ & 330 & $\mathbf{U}$ \\
\hline Chrysene & 340 & $\mathbf{U}$ & 350 & $\mathbf{U}$ & 340 & $\mathbf{U}$ & 350 & $\mathbf{U}$ & 330 & $\mathbf{U}$ \\
\hline Di-n-butylphthalate & 340 & $\mathbf{U}$ & 350 & $\mathbf{U}$ & 340 & $\mathbf{U}$ & 350 & $\mathbf{U}$ & 330 & $\mathbf{U}$ \\
\hline Di-n-octylphthalate & 340 & $\mathbf{U}$ & 350 & $\mathbf{U}$ & 340 & $\mathbf{U}$ & 350 & $\mathbf{U}$ & 330 & $\mathbf{U}$ \\
\hline Dibenz[a,h]anthracene & 340 & $\mathbf{U}$ & 350 & $\mathbf{U}$ & 340 & $\mathbf{U}$ & 350 & $\mathbf{U}$ & 330 & $\mathbf{U}$ \\
\hline Dibenzofuran & 340 & $\mathbf{U}$ & 350 & $\mathbf{U}$ & 340 & $\mathbf{U}$ & 350 & $\mathbf{U}$ & 330 & $\mathbf{U}$ \\
\hline Diethyl phthalate & 340 & $\mathbf{U}$ & 350 & $\mathbf{U}$ & 340 & $\mathbf{U}$ & 350 & $\mathbf{U}$ & 330 & $\mathbf{U}$ \\
\hline Dimethyl phthalate & 340 & $\mathbf{U}$ & 350 & $\mathbf{U}$ & 340 & $\mathbf{U}$ & 350 & $\mathbf{U}$ & 330 & $\mathbf{U}$ \\
\hline Fluoranthene & 340 & $\mathbf{U}$ & 350 & $\mathbf{U}$ & 340 & $\mathbf{U}$ & 350 & $\mathbf{U}$ & 330 & $\mathbf{U}$ \\
\hline Fluorene & 340 & $\mathbf{U}$ & 350 & $\mathrm{U}$ & 340 & $\mathbf{U}$ & 350 & $\mathbf{U}$ & 330 & $\mathbf{U}$ \\
\hline Hexachlorobenzene & 340 & $\mathbf{U}$ & 350 & $\mathbf{U}$ & 340 & $\mathbf{U}$ & 350 & $\mathbf{U}$ & 330 & $\mathbf{U}$ \\
\hline Hexachlorobutadiene & 340 & $\mathbf{U}$ & 350 & $\mathbf{U}$ & 340 & $\mathbf{U}$ & 350 & $\mathbf{U}$ & 330 & $\mathrm{U}$ \\
\hline Hexachlorocyclopentadiene & 340 & $\mathbf{U}$ & 350 & $\mathbf{U}$ & 340 & $\mathbf{U}$ & 350 & $\mathbf{U}$ & 330 & $\mathbf{U}$ \\
\hline Hexachloroethane & 340 & $\mathbf{U}$ & 350 & $\mathbf{U}$ & 340 & $\mathbf{U}$ & 350 & $\mathbf{U}$ & 330 & $\mathbf{U}$ \\
\hline Ideno(1,2,3-cd)pyrene & 340 & $\mathbf{U}$ & 350 & $\mathbf{U}$ & 340 & $\mathbf{U}$ & 350 & $\mathbf{U}$ & 330 & $\mathbf{U}$ \\
\hline Isophorone & 340 & $\mathbf{U}$ & 350 & $\mathbf{U}$ & 340 & $\mathbf{U}$ & 350 & $\mathbf{U}$ & 330 & $\mathbf{U}$ \\
\hline N-Nitroso-di-n-dipropylamine & 340 & $\mathbf{U}$ & 350 & $\mathbf{U}$ & 340 & $\mathbf{U}$ & 350 & $\mathbf{U}$ & 330 & $\mathbf{U}$ \\
\hline N-Nitrosodiphenylamine & 340 & $\mathbf{U}$ & 350 & $\mathbf{U}$ & 340 & $\mathbf{U}$ & 350 & $\mathbf{U}$ & 1600 & $\mathbf{U}$ \\
\hline
\end{tabular}


Table A-4 Chemical Analysis Results for Borehole 116-H-7 (page 6 of 7)

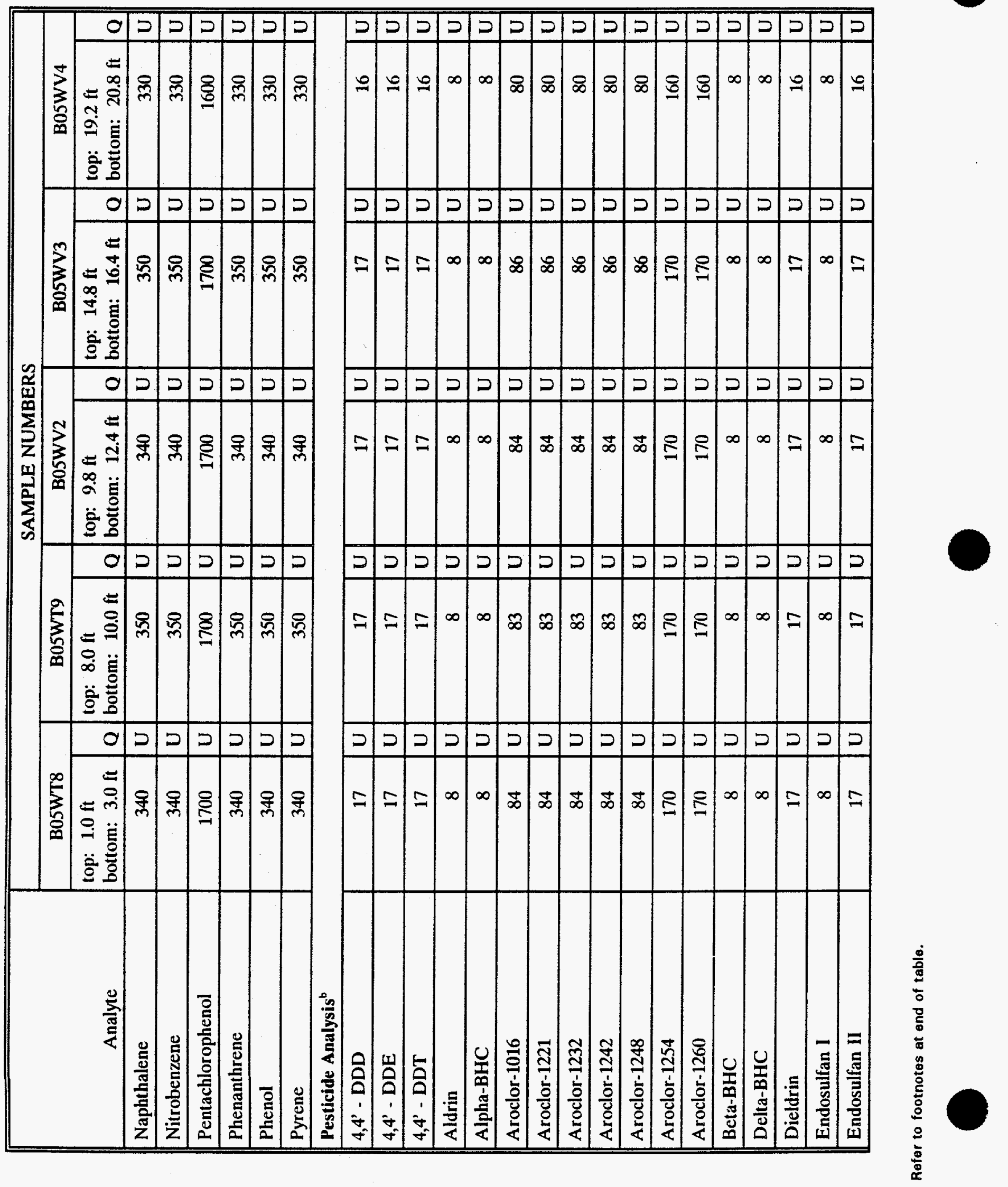




\begin{tabular}{|c|c|c|c|c|c|c|c|c|c|c|}
\hline \multirow[b]{3}{*}{ Analyte } & \multicolumn{10}{|c|}{ SAMPLE NUMBERS } \\
\hline & \multicolumn{2}{|l|}{ B05WT8 } & \multicolumn{2}{|l|}{ B05WT9 } & \multicolumn{2}{|l|}{ B05WV2 } & \multicolumn{2}{|l|}{ B05WV3 } & \multicolumn{2}{|l|}{ B05WV4 } \\
\hline & $\begin{array}{l}\text { top: } 1.0 \mathrm{ft} \\
\text { bottom: } 3.0 \mathrm{ft}\end{array}$ & $\mathbf{Q}$ & $\begin{array}{l}\text { top: } 8.0 \mathrm{ft} \\
\text { bottom: } 10.0 \mathrm{ft}\end{array}$ & $\mathbf{Q}$ & $\begin{array}{l}\text { top: } 9.8 \mathrm{ft} \\
\text { bottom: } 12.4 \mathrm{ft}\end{array}$ & $\mathbf{Q}$ & $\begin{array}{l}\text { top: } 14.8 \mathrm{ft} \\
\text { bottom: } 16.4 \mathrm{ft}\end{array}$ & $\mathbf{Q}$ & $\begin{array}{l}\text { top: } 19.2 \mathrm{ft} \\
\text { bottom: } 20.8 \mathrm{ft}\end{array}$ & $\mathbf{Q}$ \\
\hline Endosulfan sulfate & 17 & $\mathrm{U}$ & 17 & $\mathbf{U}$ & 17 & $\mathbf{U}$ & 17 & $\mathbf{U}$ & 16 & $\mathbf{U}$ \\
\hline Endrin & 17 & U & 17 & $\mathbf{U}$ & 17 & $\mathbf{U}$ & 17 & $\mathbf{U}$ & 16 & $\mathbf{U}$ \\
\hline Endrin ketone & 17 & $\mathbf{U}$ & 17 & $\mathbf{U}$ & 17 & $\mathbf{U}$ & 17 & $\mathbf{U}$ & 16 & $\mathbf{U}$ \\
\hline Heptaclor & 8 & $\mathbf{U}$ & 8 & $\mathbf{U}$ & 8 & $\mathbf{U}$ & 8 & $\mathbf{U}$ & 8 & $\mathbf{U}$ \\
\hline Heptaclor epoxide & 8 & $\mathrm{U}$ & 8 & $\mathbf{U}$ & 8 & $\mathbf{U}$ & 8 & $\mathbf{U}$ & 8 & $\mathbf{U}$ \\
\hline Methoxyclor & 84 & $\mathrm{U}$ & 83 & $\mathbf{U}$ & 84 & $\mathbf{U}$ & 86 & $\mathbf{U}$ & 80 & $\mathbf{U}$ \\
\hline Toxaphene & 170 & $\mathbf{U}$ & 170 & $\mathbf{U}$ & 170 & $U$ & 170 & $\mathbf{U}$ & 160 & $\mathbf{U}$ \\
\hline alpha-Chlordane & 84 & $\mathrm{U}$ & 83 & $\mathbf{U}$ & 84 & $\mathbf{U}$ & 86 & $\mathbf{U}$ & 80 & $\mathbf{U}$ \\
\hline
\end{tabular}

"Units in $\mathrm{mg} / \mathrm{kg}$.

Units in $\mu \mathrm{g} / \mathrm{kg}$.

$\mathbf{Q}=$ Laboratory qualifier.

$\mathbf{U}=$ Below dection limit; detection limit reported.

$\mathbf{J}=$ Estimated value-quality control discrepancies occurred .

$B=$ Detected in laboratory blank.

$\mathbf{R}=$ Data deemed unusable during data validation due to significant quality control deficiency. 
DOE/RL-93-51, Rev. 0

Table A-5 Chemical Analysis Results for Borehole 116-H-9 (page 1 of 5)

\begin{tabular}{|c|c|c|c|c|c|c|}
\hline \multirow[b]{3}{*}{ Analyte } & \multicolumn{6}{|c|}{ SAMPLE NUMBERS } \\
\hline & \multicolumn{2}{|l|}{ B05WN8* } & \multicolumn{2}{|l|}{ B05WN9 } & \multicolumn{2}{|l|}{ B05WP0 } \\
\hline & $\begin{array}{l}\text { top: } 3.1 \mathrm{ft} \\
\text { bottom: } 5.3 \mathrm{ft}\end{array}$ & $\mathbf{Q}$ & $\begin{array}{l}\text { top: } 17.6 \mathrm{ft} \\
\text { bottom: } 20.1 \mathrm{ft}\end{array}$ & $\mathbf{Q}$ & $\begin{array}{l}\text { top: } 21.7 \mathrm{ft} \\
\text { bottom: } 24.2 \mathrm{ft}\end{array}$ & $\mathbf{Q}$ \\
\hline \multicolumn{7}{|l|}{ Inorganic Analysis ${ }^{b}$} \\
\hline Aluminum & 74400.00 & & 9340.00 & & 5010.00 & \\
\hline Antimony & 80.10 & $\mathrm{U}$ & 5.90 & $\mathrm{U}$ & 6.20 & $\mathbf{U}$ \\
\hline Arsenic & 2.10 & $\mathbf{U}$ & 3.20 & $\mathrm{U}$ & 1.60 & $\mathbf{U}$ \\
\hline Barium & 672.00 & & 72.50 & & 73.50 & \\
\hline Beryllium & 4.70 & & 0.25 & & 0.26 & \\
\hline Cadmium & 10.60 & $\mathrm{U}$ & 0.75 & $\mathrm{U}$ & 1.10 & $\mathbf{U}$ \\
\hline Calcium & 79000.00 & & 6320.00 & & 5150.00 & \\
\hline Chromium & 114.00 & & 11.20 & & 8.50 & \\
\hline Cobalt & 86.40 & & 13.40 & & 6.90 & \\
\hline Copper & 195.00 & & 34.90 & & 13.10 & \\
\hline \multirow[t]{2}{*}{ fronide } & 5.10 & $\mathrm{U}$ & 5.10 & $\mathrm{U}$ & 4.90 & $\mathbf{U}$ \\
\hline & 184000.00 & & 24200.00 & & 13400.00 & \\
\hline Lead & 7.90 & & 4.20 & & 2.60 & $\mathrm{U}$ \\
\hline Magnesium & 50000.00 & & 6700.00 & & 3640.00 & \\
\hline Manganese & 3050.00 & & 280.00 & & 214.00 & \\
\hline Mercury & 0.10 & $\mathbf{U}$ & 0.09 & $\mathbf{U}$ & 0.09 & $\mathrm{U}$ \\
\hline Nickel & 132.00 & & 28.00 & & 8.00 & \\
\hline Potassium & 13000.00 & & 600.00 & & 916.00 & \\
\hline Selenium & 4.00 & $\mathrm{U}$ & 0.76 & $\mathrm{U}$ & 0.79 & $\mathrm{U}$ \\
\hline Silver & 12.90 & $\mathrm{U}$ & 0.95 & $\mathrm{U}$ & 0.99 & $\mathrm{U}$ \\
\hline Sodium & 2010.00 & & 721.00 & & 271.00 & \\
\hline Thallium & 0.59 & $\mathrm{U}$ & 0.57 & $\mathrm{U}$ & 0.59 & $\mathrm{U}$ \\
\hline Vanadium & 389.00 & & 46.70 & & 36.80 & \\
\hline Zinc & 430.00 & & 42.20 & & 32.80 & \\
\hline \multicolumn{7}{|l|}{ Organic Analysis $^{e}$} \\
\hline 1,1,1-Trichloroethane & 5 & $\mathrm{U}$ & 5 & $\mathrm{U}$ & 5 & $\mathbf{U}$ \\
\hline 1,1,2,2-Tetrachloroethane & 5 & $\mathrm{U}$ & 5 & $\mathrm{U}$ & 5 & $\mathbf{U}$ \\
\hline 1,1,2-Trichloroethane & 5 & $\mathrm{U}$ & 5 & $\mathbf{U}$ & 5 & $\mathrm{U}$ \\
\hline 1,1-Dichloroethane & 5 & $\mathrm{U}$ & 5 & $\mathbf{U}$ & 5 & $\mathbf{U}$ \\
\hline 1,1-Dichloroethene & 5 & $\mathrm{U}$ & 5 & $\mathrm{U}$ & 5 & $\mathrm{U}$ \\
\hline 1,2-Dichloroethane & 5 & $\mathrm{U}$ & 5 & $\mathrm{U}$ & 5 & $\mathrm{U}$ \\
\hline 1,2-Dichloroethene & 5 & $\mathrm{U}$ & 5 & $\mathrm{U}$ & 5 & $\mathrm{U}$ \\
\hline
\end{tabular}

Refer to footnotes at end of table. 
DOE/RL-93-51, Rev. 0

Table A-5 Chemical Analysis Results for Borehole 116-H-9 (page 2 of 5)

\begin{tabular}{|c|c|c|c|c|c|c|}
\hline \multirow[b]{3}{*}{ Analyte } & \multicolumn{6}{|c|}{ SAMPLE NUMBERS } \\
\hline & \multicolumn{2}{|l|}{ B05WN8 } & \multicolumn{2}{|l|}{ B05WN9 } & \multicolumn{2}{|l|}{ B05WP0 } \\
\hline & $\begin{array}{l}\text { top: } 3.1 \mathrm{ft} \\
\text { bottom: } 5.3 \mathrm{ft}\end{array}$ & $\mathrm{Q}$ & $\begin{array}{l}\text { top: } 17.6 \mathrm{ft} \\
\text { bottom: } 20.1 \mathrm{ft}\end{array}$ & $\mathrm{Q}$ & $\begin{array}{l}\text { top: } 21.7 \mathrm{ft} \\
\text { bottom: } 24.2 \mathrm{ft}\end{array}$ & $\mathrm{Q}$ \\
\hline 1,2-Dichloropropane & 5 & $\mathrm{U}$ & 5 & $\mathbf{U}$ & 5 & $\mathrm{U}$ \\
\hline 2-Butanone & 11 & $\mathbf{U}$ & 10 & $\mathrm{U}$ & 10 & $\mathrm{U}$ \\
\hline 2-Hexanone & 11 & $\mathbf{U}$ & 10 & $\mathbf{U}$ & 10 & $\mathrm{U}$ \\
\hline 4-Methyl-2-pentanone & 11 & $\mathrm{U}$ & 10 & $\mathrm{U}$ & 10 & $\mathrm{U}$ \\
\hline Acetone & 19 & $\mathrm{U}$ & 35 & $\mathrm{U}$ & 20 & $\mathrm{U}$ \\
\hline Benzene & 5 & $\mathbf{U}$ & 5 & $\mathbf{U}$ & 5 & $\mathrm{U}$ \\
\hline Bromodichloromethane & 5 & $\mathrm{U}$ & 5 & $\mathrm{U}$ & 5 & $\mathrm{U}$ \\
\hline Bromoform & 5 & $\mathrm{U}$ & 5 & $\mathrm{U}$ & 5 & $\mathrm{U}$ \\
\hline Bromomethane & 11 & $\mathrm{U}$ & 10 & $\mathrm{U}$ & 10 & $\mathrm{U}$ \\
\hline Carbon disulfide & 5 & $\mathrm{U}$ & 5 & $\mathbf{U}$ & 5 & $\underline{U}$ \\
\hline Carbon tetrachloride & 5 & $\mathrm{U}$ & 5 & $\mathrm{U}$ & 5 & $\mathrm{U}$ \\
\hline Chlorobenzene & 5 & $\mathrm{U}$ & 5 & $\mathrm{U}$ & 5 & $\mathbf{U}$ \\
\hline Chloroethane & 11 & $\mathbf{U}$ & 10 & $\mathbf{U}$ & 10 & $\mathbf{U}$ \\
\hline Chloroform & 5 & $\mathbf{U}$ & 5 & $\mathrm{U}$ & 5 & $\mathrm{U}$ \\
\hline Chloromethane & 11 & $\mathrm{U}$ & 10 & $\mathrm{U}$ & 10 & $\mathrm{U}$ \\
\hline Dibromochloromethane & 5 & $\mathrm{U}$ & 5 & $\mathrm{U}$ & 5 & $\mathrm{U}$ \\
\hline Ethylbenzene & 5 & $\mathrm{U}$ & 5 & $\mathrm{U}$ & 5 & $\mathbf{U}$ \\
\hline Methylene chloride & 14 & $\mathrm{U}$ & 16 & $\mathrm{U}$ & 10 & $\mathrm{U}$ \\
\hline Styrene & 5 & $\mathrm{U}$ & 5 & $\mathbf{U}$ & 5 & U \\
\hline Tetrachloroethene & 5 & $\mathbf{U}$ & 5 & $\mathrm{U}$ & 5 & $\mathrm{U}$ \\
\hline Toluene & 5 & $\mathrm{U}$ & 3 & $\mathrm{U}$ & 5 & $\mathrm{U}$ \\
\hline Trichloroethene & 5 & $\mathrm{U}$ & 5 & $\mathrm{U}$ & 5 & U \\
\hline Vinyl acetate & 11 & $\mathrm{U}$ & 10 & $\mathbf{U}$ & 10 & U \\
\hline Vinyl chloride & 11 & $\mathrm{U}$ & 10 & $\mathrm{U}$ & 10 & $\mathrm{U}$ \\
\hline Xylenes (total) & 5 & $\mathrm{U}$ & 5 & $\mathrm{U}$ & 5 & $\mathrm{U}$ \\
\hline cis-1,3-Dichloropropene & 5 & $\mathrm{U}$ & 5 & $\mathrm{U}$ & 5 & $\mathrm{U}$ \\
\hline trans-1,3-Dichloropropene & 5 & $\mathrm{U}$ & 5 & $\mathbf{U}$ & 5 & $\mathrm{U}$ \\
\hline \multicolumn{7}{|c|}{ Semivolatile Organic Analysis ${ }^{\mathfrak{c}}$} \\
\hline 1,2,4-Trichlorobenzene & 340 & $\mathbf{U}$ & 330 & $\mathrm{U}$ & 320 & $\underline{U}$ \\
\hline 1,2-Dichlorobenzene & 340 & $\mathrm{U}$ & 330 & $\underline{U}$ & 320 & $\underline{U}$ \\
\hline 1,3-Dichlorobenzene & 340 & $\mathrm{U}$ & 330 & $\mathrm{U}$ & 320 & $\underline{U}$ \\
\hline 1,4-Dichlorobenzene & 340 & $\mathrm{U}$ & 330 & $\mathrm{U}$ & 320 & $\mathrm{U}$ \\
\hline 2,4,5-Trichlorophenol & 1700 & $\mathrm{U}$ & 1600 & $\mathrm{U}$ & 1600 & $\mathrm{U}$ \\
\hline
\end{tabular}

Refer to footnotes at end of table. 
DOE/RL-93-51, Rev. 0

Table A-5 Chemical Analysis Results for Borehole 116-H-9 (page 3 of 5)

\begin{tabular}{|c|c|c|c|c|c|c|}
\hline \multirow[b]{3}{*}{ Analyte } & \multicolumn{6}{|c|}{ SAMPLE NUMBERS } \\
\hline & \multicolumn{2}{|l|}{ B05WN8" } & \multicolumn{2}{|l|}{ B05WN9 } & \multicolumn{2}{|l|}{ B05WP0 } \\
\hline & $\begin{array}{l}\text { top: } 3.1 \mathrm{ft} \\
\text { bottom: } 5.3 \mathrm{ft}\end{array}$ & $\mathrm{Q}$ & $\begin{array}{l}\text { top: } 17.6 \mathrm{ft} \\
\text { bottom: } 20.1 \mathrm{ft}\end{array}$ & $\mathrm{Q}$ & $\begin{array}{l}\text { top: } 21.7 \mathrm{ft} \\
\text { bottom: } 24.2 \mathrm{ft}\end{array}$ & $\mathrm{Q}$ \\
\hline 2,4,6-Trichlorophenol & 340 & $\mathrm{U}$ & 330 & $\mathrm{U}$ & 320 & $\mathrm{U}$ \\
\hline 2,4-Dichlorophenol & 340 & $\mathrm{U}$ & 330 & $\mathrm{U}$ & 320 & $\mathbf{U}$ \\
\hline 24-Dimethylphenol & 340 & $\mathrm{U}$ & 330 & $\mathrm{U}$ & 320 & $\mathbf{U}$ \\
\hline 2,4Dinitrophenol & 1700 & $\mathrm{U}$ & 1600 & $\mathrm{U}$ & 1600 & $\mathrm{U}$ \\
\hline 2,4-Dinitrotoluene & 340 & $\mathrm{U}$ & 330 & $\mathrm{U}$ & 320 & $\mathrm{U}$ \\
\hline 2,6-Dinitrotoluene & 340 & $\mathrm{U}$ & 330 & $\mathbf{U}$ & 320 & U \\
\hline 2-Chloronaphthalene & 340 & $\mathrm{U}$ & 330 & $\mathrm{U}$ & 320 & U \\
\hline 2-Chlorophenol & 340 & $\mathrm{U}$ & 330 & $\mathrm{U}$ & 320 & U \\
\hline 2-Methylnaphthalene & 340 & $\mathbf{U}$ & 330 & $\mathbf{U}$ & 320 & $\mathrm{U}$ \\
\hline 2-Methylphenol & 340 & $\mathbf{U}$ & 330 & $\mathrm{U}$ & 320 & U \\
\hline 2-Nitroaniline & 1700 & $\mathbf{U}$ & 1600 & $\mathrm{U}$ & 1600 & $\mathrm{U}$ \\
\hline 2-Nitrophenol & 340 & $\mathbf{U}$ & 330 & $\mathrm{U}$ & 320 & $\mathrm{U}$ \\
\hline 3-Nitroaniline & 1700 & $\mathbf{U}$ & 1600 & $\mathrm{U}$ & 1600 & $\mathrm{U}$ \\
\hline 3,3-Dichlorbenzidine & 690 & $\mathrm{U}$ & 690 & $\mathrm{U}$ & 650 & $\mathrm{U}$ \\
\hline 4,6-Dinitro-2-methyl phenol & 1700 & $\mathrm{U}$ & 1600 & $\mathrm{U}$ & 1600 & $\mathbf{U}$ \\
\hline 4-Bromophenylphenyl ether & 340 & $\mathrm{U}$ & 330 & $\mathbf{U}$ & 320 & $\mathrm{U}$ \\
\hline 4-Chloro-3-methylphenol & 340 & $\mathbf{U}$ & 330 & $\mathrm{U}$ & 320 & $\mathrm{U}$ \\
\hline 4-Chlorophenylphenyl ether & 340 & $\mathrm{U}$ & 330 & $\mathrm{U}$ & 320 & $\mathbf{U}$ \\
\hline 4-Chloroaniline & 340 & $\mathrm{U}$ & 330 & $\mathrm{U}$ & 320 & $\mathrm{U}$ \\
\hline 4-Methylphenol & 340 & $\mathbf{U}$ & 330 & $\mathrm{U}$ & 320 & $\mathrm{U}$ \\
\hline 4-Nitroaniline & 1700 & $\mathrm{U}$ & 330 & $\mathrm{U}$ & 320 & $\mathrm{U}$ \\
\hline 4-Nitrophenol & 1700 & $\mathbf{U}$ & 1600 & $\mathrm{U}$ & 1600 & $\mathrm{U}$ \\
\hline Acenaphthene & 340 & $\mathrm{U}$ & 330 & $\mathrm{U}$ & 320 & U \\
\hline Acenaphthylene & 340 & $\mathrm{U}$ & 330 & $\mathrm{U}$ & 320 & U \\
\hline Anthracene & 340 & $\mathrm{U}$ & 330 & $\mathrm{U}$ & 320 & $\underline{U}$ \\
\hline Benzo(a)anthracene & 340 & $\mathrm{U}$ & 330 & $\mathrm{U}$ & 320 & $\mathrm{U}$ \\
\hline Benzo(a)pyrene & 340 & $\mathbf{U}$ & 330 & $\mathrm{U}$ & 320 & $\mathrm{U}$ \\
\hline Benzo(b)fluoranthene & 340 & $\mathrm{U}$ & 330 & $\mathrm{U}$ & 320 & $\underline{U}$ \\
\hline Benzo(ghi)perylene & 340 & $\mathrm{U}$ & 330 & $\mathrm{U}$ & 320 & $\mathrm{U}$ \\
\hline Benzo(k)fluoranthene & 340 & $\mathrm{U}$ & 330 & $\mathrm{U}$ & 320 & $\mathrm{U}$ \\
\hline Benzoic acid & 1700 & $\mathrm{U}$ & 330 & $\mathrm{U}$ & 320 & $\mathrm{U}$ \\
\hline Benzyl alcohol & 340 & $\mathrm{U}$ & 330 & $\mathrm{U}$ & 320 & $\underline{U}$ \\
\hline Bis(2-chloroethoxy)methane & 340 & $\mathrm{U}$ & 330 & $\mathrm{U}$ & 320 & $\mathrm{U}$ \\
\hline
\end{tabular}

Refer to footnotes at end of table. 
DOE/RL-93-51, Rev. 0

Table A-5 Chemical Analysis Results for Borehole 116-H-9 (page 4 of 5)

\begin{tabular}{|c|c|c|c|c|c|c|}
\hline \multirow[b]{3}{*}{ Analyte } & \multicolumn{6}{|c|}{ SAMPLE NUMBERS } \\
\hline & \multicolumn{2}{|l|}{ B05WN8 } & \multicolumn{2}{|l|}{ B05WN9 } & \multicolumn{2}{|l|}{ B05WP0 } \\
\hline & $\begin{array}{l}\text { top: } 3.1 \mathrm{ft} \\
\text { bottom: } 5.3 \mathrm{ft}\end{array}$ & $\mathrm{Q}$ & $\begin{array}{l}\text { top: } 17.6 \mathrm{ft} \\
\text { bottom: } 20.1 \mathrm{ft}\end{array}$ & $\mathrm{Q}$ & $\begin{array}{l}\text { top: } 21.7 \mathrm{ft} \\
\text { bottom: } 24.2 \mathrm{ft}\end{array}$ & $\mathrm{Q}$ \\
\hline Bis(2-chloroethyl)ether & 340 & $\mathrm{U}$ & 330 & $\mathrm{U}$ & 320 & $\mathrm{U}$ \\
\hline Bis(2-chloroisopropyl)ether & 340 & $\mathrm{U}$ & 330 & $\mathrm{U}$ & 320 & $\mathbf{U}$ \\
\hline Bis(2-ethylhexy)phthalate & 340 & $\mathbf{U}$ & 330 & $\mathrm{U}$ & 320 & $\mathbf{U}$ \\
\hline Butylbenzylphthalate & 340 & $\mathrm{U}$ & 330 & $\mathrm{U}$ & 320 & $\mathbf{U}$ \\
\hline Chrysene & 340 & $\mathrm{U}$ & 330 & $\mathrm{U}$ & 320 & $\mathbf{U}$ \\
\hline Di-n-butylphthalate & 340 & $\mathrm{U}$ & 330 & $\mathrm{U}$ & 320 & U \\
\hline Di-n-octylphthalate & 340 & $\mathrm{U}$ & 330 & $\mathrm{U}$ & 320 & $\mathbf{U}$ \\
\hline Dibenz[a,h]anthracene & 340 & $\mathrm{U}$ & 330 & $\mathrm{U}$ & 320 & $\mathrm{U}$ \\
\hline Dibenzofuran & 340 & $\mathbf{U}$ & 330 & $\mathrm{U}$ & 320 & $\mathbf{U}$ \\
\hline Diethyl phthalate & 340 & $\mathbf{U}$ & 330 & $\mathrm{U}$ & 320 & $\mathrm{U}$ \\
\hline Dimethyl phthalate & 340 & $\mathbf{U}$ & 330 & $\mathrm{U}$ & 320 & $\mathbf{U}$ \\
\hline Fluoranthene & 340 & U & 330 & $\mathrm{U}$ & 320 & $\mathbf{U}$ \\
\hline Fluorene & 340 & $\mathrm{U}$ & 330 & $\mathbf{U}$ & 320 & $\mathbf{U}$ \\
\hline Hexachlorobenzene & 340 & $\mathrm{U}$ & 330 & $\mathbf{U}$ & 320 & $\mathbf{U}$ \\
\hline Hexachlorobutadiene & 340 & $\mathrm{U}$ & 330 & $\mathbf{U}$ & 320 & $\mathbf{U}$ \\
\hline Hexachlorocyclopentadiene & 340 & $\mathrm{U}$ & 330 & $\mathrm{U}$ & 320 & $\mathrm{U}$ \\
\hline Hexachloroethane & 340 & $\mathrm{U}$ & 330 & $\mathrm{U}$ & 320 & $\mathrm{U}$ \\
\hline Ideno(1,2,3-cd)pyrene & 340 & $\mathrm{U}$ & 330 & $\mathrm{U}$ & 320 & $\mathbf{U}$ \\
\hline Isophorone & 340 & $\mathbf{U}$ & 330 & $\mathrm{U}$ & 320 & $\mathrm{U}$ \\
\hline N-Nitroso-di-n-dipropylamine & 340 & $\mathrm{U}$ & 330 & $\mathrm{U}$ & 320 & $\mathrm{U}$ \\
\hline $\mathrm{N}$-Nitrosodiphenylamine & 340 & $\mathrm{U}$ & 1600 & $\mathrm{U}$ & 1600 & $\mathrm{U}$ \\
\hline Naphthalene & 340 & $\mathrm{U}$ & 330 & $\mathrm{U}$ & 320 & $\mathrm{U}$ \\
\hline Nitrobenzene & 340 & $\mathrm{U}$ & 330 & $\mathrm{U}$ & 320 & $\mathbf{U}$ \\
\hline Pentachlorophenol & 1700 & $\underline{\mathbf{U}}$ & 1600 & $\mathrm{U}$ & 1600 & $\mathbf{U}$ \\
\hline Phenanthrene & 340 & $\mathrm{U}$ & 330 & $\mathrm{U}$ & 320 & $\mathrm{U}$ \\
\hline Phenol & 340 & $\mathrm{U}$ & 330 & $\mathrm{U}$ & 320 & $\mathrm{U}$ \\
\hline Pyrene & 340 & $\mathrm{U}$ & 330 & $\mathrm{U}$ & 320 & $\mathrm{U}$ \\
\hline \multicolumn{7}{|l|}{ Pesticide Analysis ${ }^{c}$} \\
\hline 4,4'- DDD & 16 & $\mathbf{U}$ & 16 & $\mathrm{U}$ & 16 & $\mathbf{U}$ \\
\hline 4,4' - DDE & 16 & $\mathbf{U}$ & 16 & $\mathrm{U}$ & 16 & $\mathbf{U}$ \\
\hline $4,4^{\prime}-\mathrm{DDT}$ & 16 & $\mathrm{U}$ & 16 & $\mathrm{U}$ & 16 & $\mathrm{U}$ \\
\hline Aldrin & 8 & $\mathrm{U}$ & 8 & $\mathrm{U}$ & 7 & $\mathrm{U}$ \\
\hline Alpha-BHC & 8 & $\mathrm{U}$ & 8 & $\mathrm{U}$ & 7 & $\mathrm{U}$ \\
\hline
\end{tabular}

Refer to footnotes at end of table. 
Table A-5 Chemical Analysis Results for Borehole 116-H-9 (page 5 of 5)

\begin{tabular}{|c|c|c|c|c|c|c|}
\hline \multirow[b]{3}{*}{ Analyte } & \multicolumn{6}{|c|}{ SAMPLE NUMBERS } \\
\hline & \multicolumn{2}{|l|}{ B05WN8: } & \multicolumn{2}{|l|}{ B05WN9 } & \multicolumn{2}{|l|}{ B05WP0 } \\
\hline & $\begin{array}{l}\text { top: } 3.1 \mathrm{ft} \\
\text { bottom: } 5.3 \mathrm{ft}\end{array}$ & $\mathrm{Q}$ & $\begin{array}{l}\text { top: } 17.6 \mathrm{ft} \\
\text { bottom: } 20.1 \mathrm{ft}\end{array}$ & $\mathrm{Q}$ & $\begin{array}{l}\text { top: } 21.7 \mathrm{ft} \\
\text { bottom: } 24.2 \mathrm{ft}\end{array}$ & $\mathrm{Q}$ \\
\hline Aroclor-1016 & 81 & $\mathrm{U}$ & 80 & $\mathrm{U}$ & 78 & $\mathrm{U}$ \\
\hline Arocior-1221 & 81 & $\mathrm{U}$ & 80 & $\mathrm{U}$ & 78 & $\mathrm{U}$ \\
\hline Aroclor-1232 & 81 & $\mathrm{U}$ & 80 & $\mathrm{U}$ & 78 & $\mathrm{U}$ \\
\hline Aroclor-1242 & 81 & $\mathrm{U}$ & 80 & $\mathrm{U}$ & 78 & $\mathrm{U}$ \\
\hline Aroclor-1248 & 81 & $\mathrm{U}$ & 80 & $\mathrm{U}$ & 78 & $\mathrm{U}$ \\
\hline Aroclor-1254 & 160 & $\mathrm{U}$ & 160 & $\mathbf{U}$ & 160 & $\mathbf{U}$ \\
\hline Aroclor- 1260 & 160 & $\mathrm{U}$ & 160 & $\mathbf{U}$ & 160 & $\mathbf{U}$ \\
\hline Beta-BHC & 8 & $\mathrm{U}$ & 8 & $\mathrm{U}$ & 7 & $\mathrm{U}$ \\
\hline Delta-BHC & 8 & $\mathrm{U}$ & 8 & $\mathrm{U}$ & 7 & $\mathrm{U}$ \\
\hline Dieldrin & 16 & $\mathrm{U}$ & 16 & $\mathrm{U}$ & 16 & $\mathbf{U}$ \\
\hline Endosulfan I & 8 & $\mathrm{U}$ & 8 & $\mathbf{U}$ & 7 & $\mathrm{U}$ \\
\hline Endosulfan II & 16 & $\mathrm{U}$ & 16 & $\mathrm{U}$ & 16 & $\mathrm{U}$ \\
\hline Endosulfan sulfate & 16 & $\mathrm{U}$ & 16 & $\mathrm{U}$ & 16 & $\mathbf{U}$ \\
\hline Endrin & 16 & $\mathrm{U}$ & 16 & $\mathrm{U}$ & 16 & $\mathbf{U}$ \\
\hline Endrin ketone & 16 & $\mathrm{U}$ & 16 & $\mathrm{U}$ & 16 & $\mathbf{U}$ \\
\hline Gamma-BHC (Lindane) & 8 & $\mathrm{U}$ & 8 & $\mathrm{U}$ & 7 & $\mathbf{U}$ \\
\hline Heptaclor & 8 & $\mathbf{U}$ & 8 & $\mathrm{U}$ & 7 & $\mathbf{U}$ \\
\hline Heptaclor epoxide & 8 & $\mathrm{U}$ & 8 & $\mathrm{U}$ & 7 & $\mathrm{U}$ \\
\hline Methoxyclor & 81 & $\mathrm{U}$ & 80 & $\mathrm{U}$ & 78 & $\mathrm{U}$ \\
\hline Toxaphene & 160 & $\mathrm{U}$ & 160 & $\mathrm{U}$ & 160 & $\mathrm{U}$ \\
\hline alpha-Chlordane & 81 & $\mathrm{U}$ & 80 & $\mathrm{U}$ & 78 & $\mathrm{U}$ \\
\hline gamma-Chlordane & 81 & $U$ & 80 & $\mathrm{U}$ & 78 & $\mathrm{U}$ \\
\hline
\end{tabular}

"Inorganic analysis results are suspect. The indicated levels of inorganic constituents is unrealistic for Sample B05WN8. The metal constituents for this soil sample add up to over $50 \%$ of the sample. This percentage does not include the major mineral elements of silicon, oxygen, carbon, and hydrogen. The levels appear to be approximately 10 times what would be expected for almost all of the inorganic constituents. Upon further investigation of the original laboratory records, it was discovered that an error was made in reporting the results and these results are incorrect. The inorganic analytical results for this sample are not used in the LFI evaluation of this site.

'Units in $\mathrm{mg} / \mathrm{kg}$.

Units in $\mu \mathrm{g} / \mathrm{kg}$.

$\mathrm{Q}=$ Laboratory qualifier.

$\mathrm{U}=$ Below dection limit; detection limit reported.

$\mathrm{J}=$ Estimated value-quality control discrepancies occurred.

$B=$ Detected in laboratory blank. 


\begin{tabular}{|c|c|c|c|c|c|c|c|c|c|c|c|c|}
\hline \multirow[b]{3}{*}{ Radionuclide } & \multicolumn{12}{|c|}{ Sample Numbers } \\
\hline & \multicolumn{2}{|l|}{ B05WV5 } & \multicolumn{2}{|l|}{ B05WV6 } & \multicolumn{2}{|l|}{ B05WV8 } & \multicolumn{2}{|l|}{ B05WV9 } & \multicolumn{2}{|l|}{ B05WW0 } & \multicolumn{2}{|l|}{ B05WW4 } \\
\hline & $\begin{array}{l}\text { top: } 10.0 \mathrm{ft} \\
\text { bottom: } 12.0 \mathrm{ft}\end{array}$ & $\mathbf{Q}$ & $\begin{array}{l}\text { top: } 13.6 \mathrm{ft} \\
\text { bottom: } 15.6 \mathrm{ft}\end{array}$ & $\mathbf{Q}$ & $\begin{array}{l}\text { top: } 15.0 \mathrm{ft} \\
\text { bottom: } 17.0 \mathrm{ft}\end{array}$ & $\mathbf{Q}$ & \begin{tabular}{|l|} 
top: $16.5 \mathrm{ft}$ \\
bottom: $17.8 \mathrm{ft}$
\end{tabular} & $\mathbf{Q}$ & $\begin{array}{l}\text { top: } 19.3 \mathrm{ft} \\
\text { bottom: } 20.8 \mathrm{ft} \\
\end{array}$ & $\mathbf{Q}$ & $\begin{array}{l}\text { top: } 24.0 \mathrm{ft} \\
\text { bottom: } 25.1 \mathrm{ft}\end{array}$ & $\mathbf{Q}$ \\
\hline U-233/234 & NA & & 0 & $\mathbf{U}$ & 0.53 & & 0.62 & & NA & & NA & \\
\hline U-235 & 0.031 & $\mathbf{U}$ & 0 & $\mathbf{U}$ & 0.025 & $\mathbf{U}$ & 0.13 & $\mathbf{U}$ & 0.05 & $\mathbf{U}$ & 0.043 & $\mathbf{U}$ \\
\hline $\mathrm{U}-238$ & 0.61 & & 0 & $\mathbf{U}$ & 0.31 & & 0.23 & $\mathbf{J}$ & 0.39 & & 0.58 & \\
\hline $\mathrm{Pu}-239 / 240$ & 0.74 & & 0.58 & & 0.64 & & 0.33 & & 0.063 & & 0.034 & $\mathbf{J}$ \\
\hline Am-241 & 0.2 & & 0.16 & & 0.16 & & 0.068 & & 0 & $\mathbf{U}$ & 0.006 & $\mathbf{U}$ \\
\hline $\mathrm{Sr}-90$ & 1.5 & $\mathbf{J}$ & 1.5 & $\mathbf{J}$ & 6.2 & & 5.5 & & 1.3 & $\mathbf{J}$ & -0.081 & U \\
\hline Tc-99 & 0.25 & $\mathbf{U}$ & 0.25 & $\mathbf{J}$ & 0.18 & $\mathbf{J}$ & 0.67 & & 0.21 & $\mathbf{U}$ & -0.076 & U \\
\hline Co-60 & 2.5 & & 1.8 & & 2.2 & & 2 & & 0 & $\mathrm{U}$ & 0 & $\mathbf{U}$ \\
\hline Cs-137 & 32 & & 24 & & 23 & & 11 & & 0.25 & & 0 & U \\
\hline Ra-226 & NA & & 0 & $\mathbf{U}$ & 0.78 & & 0.85 & & 0.55 & & 0.4 & \\
\hline Th-228 & NA & & 0.95 & & 0.52 & & 0.44 & & 0.75 & & 0.53 & \\
\hline Th-232 & NA & & 0 & $\mathbf{U}$ & 0 & $\mathbf{U}$ & 0 & $\mathbf{U}$ & 0.89 & & 0.64 & \\
\hline Eu-152 & 54 & & 36 & & 34 & & 42 & & 0.72 & & NA & \\
\hline Eu-154 & 5.4 & & 3.6 & & 3.6 & & 3.6 & & 0.34 & & NA & \\
\hline
\end{tabular}

Units in pCi/g.

$\mathbf{Q}=$ Laboratory qualifier.

$\mathrm{U}=$ Below detection limit; detection limit reported.

$\mathbf{J}=$ Estimated value; quality control discrapencies occurred.

$\mathrm{NA}=$ Not detected. 
DOE/RL-93-51, Rev. 0

Table A-7 Radionuclide Analysis Results for Borehole 116-H-2

\begin{tabular}{|c|c|c|c|c|c|c|}
\hline \multirow[b]{3}{*}{ Radionuclide $^{\mathrm{a}}$} & \multicolumn{6}{|c|}{ Sample Numbers } \\
\hline & \multicolumn{2}{|l|}{ B05WW5 } & \multicolumn{2}{|l|}{ B05WW6 } & \multicolumn{2}{|l|}{ B05WW7 } \\
\hline & $\begin{array}{l}\text { top: } 9.9 \mathrm{ft} \\
\text { bottom: } 12.1 \mathrm{ft}\end{array}$ & $Q$ & $\begin{array}{l}\text { top: } 14.9 \mathrm{ft} \\
\text { bottom: } 17.2 \mathrm{ft}\end{array}$ & Q & $\begin{array}{l}\text { top: } 14.9 \mathrm{ft} \\
\text { bottom: } 17.2 \mathrm{ft}\end{array}$ & $Q$ \\
\hline U-233/234 & NA & & NA & & NA & \\
\hline U-235 & 0 & $\mathrm{U}$ & 0 & $\mathrm{U}$ & 0 & $\bar{U}$ \\
\hline U-238 & 0.33 & & 0.54 & & 0.5 & \\
\hline Pu-239/240 & 0 & $\mathrm{U}$ & 0 & $\mathrm{U}$ & 0.006 & $\mathbf{U}$ \\
\hline Am-241 & 0.004 & $\mathrm{U}$ & 0.002 & $\mathrm{U}$ & -0.033 & $\mathbf{U}$ \\
\hline Sr-90 & -0.02 & $\mathrm{U}$ & -0.76 & $\mathrm{U}$ & -0.24 & $\mathbf{U}$ \\
\hline Tc-99 & 0.14 & $U$ & 0.084 & $\mathrm{U}$ & 0.42 & $\mathrm{U}$ \\
\hline Co-60 & 0 & $\mathrm{U}$ & 0 & $\mathrm{U}$ & 0 & $\mathrm{U}$ \\
\hline Cs- 137 & 0 & $\mathrm{U}$ & 0 & $\mathrm{U}$ & 0 & $\mathrm{U}$ \\
\hline $\mathrm{Ra}-226$ & 0.37 & & 0.47 & & 0.5 & \\
\hline Th-228 & 0.49 & & 0.5 & & 0.63 & \\
\hline Th-232 & 0.35 & & 0 & $\mathbf{U}$ & 0 & $\mathrm{U}$ \\
\hline Eu-152 & NA & & NA & & NA & \\
\hline Eu-154 & $\mathrm{NA}$ & & NA & & NA & \\
\hline
\end{tabular}

${ }^{2}$ Units in $\mathrm{pCi} / \mathrm{g}$.

$\mathrm{Q}=$ Laboratory qualifier.

$\mathrm{U}=$ Below detection limit; detection limit reported.

$\mathrm{J}=$ Estimated value; quality control discrepancies occurred.

$\mathrm{NA}=$ Not detected. 
DOE/RL-93-51, Rev. 0

Table A-8 Radionuclide Analysis Results for Borehole 116-H-3

\begin{tabular}{|c|c|c|c|c|}
\hline \multirow[b]{3}{*}{ Radionuclide $^{\mathrm{a}}$} & \multicolumn{4}{|c|}{ Sample Numbers } \\
\hline & \multicolumn{2}{|l|}{ B05WP1 } & \multicolumn{2}{|l|}{ B05WP5 } \\
\hline & $\begin{array}{l}\text { top: } 14.5 \mathrm{ft} \\
\text { bottom: } 16.3 \mathrm{ft}\end{array}$ & Q & $\begin{array}{l}\text { top: } 19.6 \mathrm{ft} \\
\text { bottom: } 21.7 \mathrm{ft}\end{array}$ & Q \\
\hline U-233/234 & NA & & 0.35 & \\
\hline $\mathrm{U}-235$ & 0.016 & $\mathrm{U}$ & 0 & $\mathrm{U}$ \\
\hline U-238 & 0.58 & & 0.44 & \\
\hline $\mathrm{Pu}-239 / 240$ & 0.006 & $\mathrm{U}$ & 0 & $\mathrm{U}$ \\
\hline Am-241 & 0.009 & $\mathrm{U}$ & 0.011 & $\mathrm{U}$ \\
\hline Sr-90 & 0.048 & $\mathrm{U}$ & 0.24 & $\mathrm{U}$ \\
\hline Tc-99 & 0.52 & $\bar{U}$ & 0.2 & $\mathrm{U}$ \\
\hline $\mathrm{Co}-60$ & 0.38 & & 0.13 & \\
\hline Cs- 137 & 0 & $\mathrm{U}$ & 0 & $\mathrm{U}$ \\
\hline Ra-226 & 0 & $\mathrm{U}$ & 0.45 & \\
\hline Th-228 & 0.58 & & 0.57 & \\
\hline Th-232 & 0.44 & & 0.39 & \\
\hline Eu-152 & 0.54 & & NA & \\
\hline Eu-154 & NA & & NA & \\
\hline
\end{tabular}

${ }^{\mathrm{a}}$ Units in $\mathrm{pCi} / \mathrm{g}$.

$\mathrm{Q}=$ Laboratory qualifier.

$\mathrm{U}=$ Below detection limit; detection limit reported.

$\mathrm{J}=$ Estimated value; quality control discrepancies occurred.

$\mathrm{NA}=$ Not detected. 


\begin{tabular}{|c|c|c|c|c|c|c|c|c|c|c|}
\hline \multirow[b]{3}{*}{ Radionuclide" } & \multicolumn{10}{|c|}{ Sample Numbers } \\
\hline & \multicolumn{2}{|l|}{ B05WT8 } & \multicolumn{2}{|l|}{ B05WT9 } & \multicolumn{2}{|l|}{ B05WV2 } & \multicolumn{2}{|l|}{ B05WV3 } & \multicolumn{2}{|l|}{ B05WV4 } \\
\hline & $\begin{array}{l}\text { top: } 1.0 \mathrm{ft} \\
\text { bottom: } 3.0 \mathrm{ft}\end{array}$ & $Q$ & $\begin{array}{l}\text { top: } 8.0 \mathrm{ft} \\
\text { bottom: } 10.0 \mathrm{ft}\end{array}$ & $Q$ & $\begin{array}{l}\text { top: } 9.8 \mathrm{ft} \\
\text { bottom: } 12.4 \mathrm{ft}\end{array}$ & $\mathbf{Q}$ & $\begin{array}{l}\text { top: } 14.8 \mathrm{ft} \\
\text { bottom: } 16.4 \mathrm{ft}\end{array}$ & $\mathbf{Q}$ & $\begin{array}{l}\text { top: } 19.2 \mathrm{ft} \\
\text { bottom: } 20.8 \mathrm{ft}\end{array}$ & $Q$ \\
\hline U-233/234 & NA & & NA & & NA & & NA & & NA & \\
\hline U-235 & 0.023 & $\mathrm{U}$ & 0.013 & $\mathrm{U}$ & 0.38 & & 0.018 & $\mathbf{U}$ & 0.014 & $\mathbf{U}$ \\
\hline $\mathrm{U}-238$ & 0.69 & & 0.47 & & 0.68 & & 0.5 & & 0.53 & \\
\hline $\mathrm{Pu}-239 / 240$ & 0.026 & $\mathrm{~J}$ & $\overline{1.1}$ & & 1.3 & & 0.073 & & 0.003 & $\mathbf{U}$ \\
\hline Am-241 & 0.011 & $\mathrm{U}$ & 0.54 & & 0.72 & & 0.031 & $\mathrm{U}$ & 0.011 & $\mathrm{U}$ \\
\hline Sr-90 & -0.15 & $U$ & 3.2 & & 0.93 & $\mathbf{J}$ & -0.7 & $\mathbf{U}$ & 1.2 & $\mathrm{~J}$ \\
\hline Tc-99 & 0.15 & $\mathrm{U}$ & 0.33 & $\mathrm{U}$ & 0.095 & $\mathbf{U}$ & 0.26 & $\mathbf{U}$ & 0.22 & $\mathrm{U}$ \\
\hline Co-60 & 0 & $\mathrm{U}$ & 14 & & 36 & & 0.68 & & 0 & $\mathbf{U}$ \\
\hline Cs-137 & 0 & $\mathrm{U}$ & 11 & & 35 & & 1.7 & & 0 & $\mathbf{U}$ \\
\hline $\mathrm{Ra}-226$ & 0.29 & & 0 & $\mathrm{U}$ & 0 & $\mathbf{U}$ & 0.65 & & 0.44 & \\
\hline Th-228 & 0.41 & & 0 & $\mathrm{U}$ & 0 & $\mathbf{U}$ & 0.81 & & 0.46 & \\
\hline Th-232 & 0.41 & & 0 & $\mathrm{U}$ & 0 & $\mathrm{U}$ & 0 & $\mathbf{U}$ & 0.44 & \\
\hline Eu-152 & NA & & 120 & & 260 & & 4 & & NA & \\
\hline Eu-154 & NA & & 19 & & 37 & & 0.5 & & NA & \\
\hline
\end{tabular}

${ }^{2}$ Units in $\mathrm{pCi} / \mathrm{g}$.

$\mathrm{Q}=$ Laboratory qualifier.

$\mathrm{U}=$ Below detection limit; detection limit reported.

$\mathrm{J}=$ Estimated value; quality control discrepancies occurred.

NA $=$ Not detected. 
DOE/RL-93-51, Rev. 0

Table A-10 Radionuclide Analysis Results for Borehole 116-H-9

\begin{tabular}{|c|c|c|c|c|c|c|}
\hline \multirow[b]{3}{*}{ Radionuclides $\mathbf{a}$} & \multicolumn{6}{|c|}{ Sample Numbers } \\
\hline & \multicolumn{2}{|l|}{ B05WN8 } & \multicolumn{2}{|l|}{ B05WN9 } & \multicolumn{2}{|l|}{ B05WP0 } \\
\hline & $\begin{array}{l}\text { top: } 3.1 \mathrm{ft} \\
\text { bottom: } 5.3 \mathrm{ft}\end{array}$ & $Q$ & $\begin{array}{l}\text { top: } 17.6 \mathrm{ft} \\
\text { bottom: } 20.1 \mathrm{ft}\end{array}$ & Q & $\begin{array}{l}\text { top: } 21.7 \mathrm{ft} \\
\text { bottom: } 24.2 \mathrm{ft}\end{array}$ & Q \\
\hline $\mathrm{U}-233 / 234$ & NA & & NA & & NA & \\
\hline U-235 & 0.029 & $\mathrm{U}$ & 0 & $\mathrm{U}$ & 0.015 & $\mathrm{U}$ \\
\hline U-238 & 0.47 & & 0.19 & $\bar{U}$ & 0.45 & \\
\hline $\mathrm{Pu}-239 / 240$ & 0.004 & $\mathrm{U}$ & 0.024 & $\mathrm{U}$ & 0.004 & $\mathrm{U}$ \\
\hline $\mathrm{Am}-241$ & 0.023 & $\mathrm{U}$ & 0.01 & $\mathrm{U}$ & 0 & $U$ \\
\hline Sr-90 & 0.085 & $\mathrm{U}$ & -0.18 & $\mathrm{U}$ & -0.16 & $\mathrm{U}$ \\
\hline Tc-99 & -0.13 & $\mathrm{U}$ & 0.23 & $\bar{U}$ & 0.17 & $\bar{U}$ \\
\hline Co-60 & 0 & $\mathrm{U}$ & 0 & $\bar{U}$ & 0 & $\mathrm{U}$ \\
\hline Cs-137 & 0 & $\mathrm{U}$ & 0.29 & & 0 & $\mathrm{U}$ \\
\hline $\mathrm{Ra}-226$ & 0.64 & & 0.71 & & 0.5 & \\
\hline Th-228 & 1.2 & & 1.1 & & 0.73 & \\
\hline Th-232 & 0.75 & & 1.1 & & 0.39 & \\
\hline Eu-152 & NA & & 0.36 & & $\mathrm{NA}$ & \\
\hline Eu-154 & NA & & NA & & NA & \\
\hline
\end{tabular}

${ }^{2}$ Units in $\mathrm{pCi} / \mathrm{g}$.

$\mathrm{Q}=$ Laboratory qualifier.

$\mathrm{U}=$ Below detection limit; detection limit reported.

$\mathrm{J}=$ Estimated value; quality control discrepancies occurred.

$\mathrm{NA}=$ Not detected. 
DOE/RL-93-51, Rev. 0

Appendix B

RESULTS OF LABORATORY ANALYSES FOR LOW-PRIORITY SITES 
Table B-1 Chemical Analysis Results for Septic Tank 1607-H-2 (page 1 of 3)

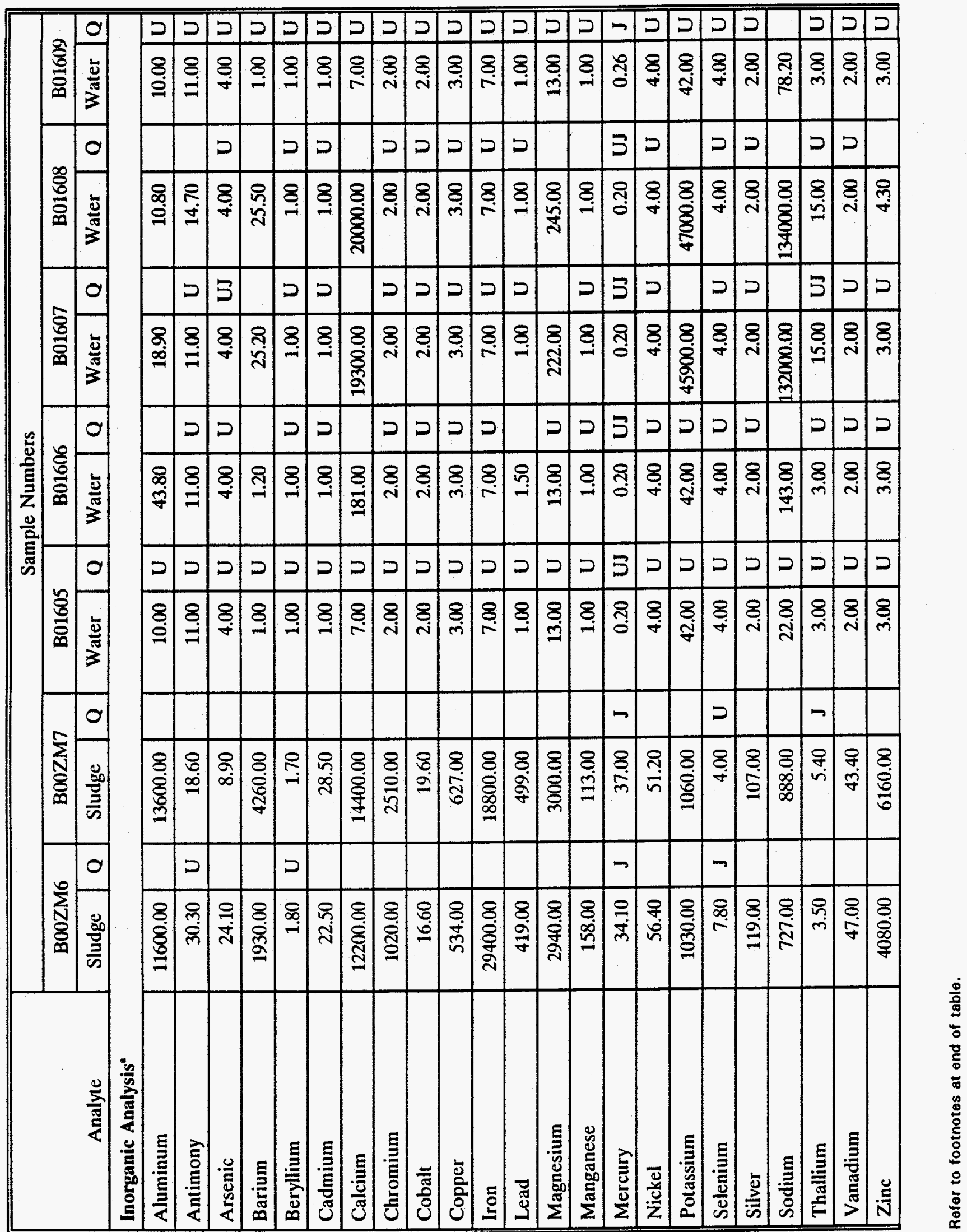




\begin{tabular}{|c|c|c|c|c|c|c|c|c|c|c|c|c|c|c|}
\hline \multirow[b]{3}{*}{ Analyte } & \multicolumn{14}{|c|}{ Sample Numbers } \\
\hline & \multicolumn{2}{|c|}{ B00ZM6 } & \multicolumn{2}{|c|}{ B00ZM7 } & \multicolumn{2}{|c|}{ B01605 } & \multicolumn{2}{|c|}{ B01606 } & \multicolumn{2}{|c|}{ B01607 } & \multicolumn{2}{|c|}{ B01608 } & \multicolumn{2}{|c|}{ B01609 } \\
\hline & Sludge & $\mathbf{Q}$ & Sludge & $\mathbf{Q}$ & Water & $\mathbf{Q}$ & Water & $\mathbf{Q}$ & Water & $\mathbf{Q}$ & Water & $Q$ & Water & $\mathbf{Q}$ \\
\hline \multicolumn{15}{|l|}{ Wet Chemistry Analysis* } \\
\hline Fluoride & & & & & 0.24 & & 0.24 & & 1.96 & & 0.25 & & 0.24 & \\
\hline Chloride & & & & & 0.03 & $\mathbf{U}$ & 0.03 & $\mathbf{U}$ & 0.03 & $\mathbf{U}$ & 0.03 & $\mathbf{U}$ & 0.03 & $\mathbf{U}$ \\
\hline Nitrite & 1.20 & & 1.00 & $\mathbf{U}$ & 0.03 & $\mathbf{U}$ & 0.03 & $\mathrm{U}$ & 0.56 & & 0.56 & & 0.03 & $\mathbf{U}$ \\
\hline Nitrate & 15.20 & & 5.00 & & 5.00 & $\mathbf{U}$ & 5.00 & $\mathbf{U}$ & 130.00 & & 130.00 & & 5.00 & $\mathbf{U}$ \\
\hline Sulfate & 4425.00 & & 7115.00 & & & & & & & & & & & \\
\hline \multicolumn{15}{|l|}{ Organic Analysis $^{\mathrm{b}}$} \\
\hline Chloromethane & 91 & UJ & 45 & UJ & 10 & $\mathbf{U J}$ & 10 & UJ & 10 & UJ & 10 & UJ & 10 & $\mathbf{U}$ \\
\hline Bromomethane & 91 & UJ & 45 & UJ & 10 & $\mathbf{U J}$ & 10 & $\mathbf{U J}$ & 10 & UJ & 10 & UJ & 10 & $\mathbf{U}$ \\
\hline Vinyl Chloride & 91 & $\mathbf{U J}$ & 45 & UJ & 10 & $\mathbf{U J}$ & 10 & $\mathbf{U J}$ & 10 & UJ & 10 & UJ & 10 & $\mathbf{U}$ \\
\hline Chloroethane & 91 & UJ & 45 & UJ & 10 & UJ & 10 & $\mathbf{U J}$ & 10 & UJ & 10 & UJ & 10 & $\mathrm{U}$ \\
\hline Methylene Chloride & 91 & UJ & 45 & UJ & 10 & $\mathbf{U J}$ & 10 & $\mathbf{U J}$ & 10 & UJ & 10 & UJ & 300 & $\mathbf{J}$ \\
\hline Acetone & 770 & UJ & 450 & UJ & 10 & UJ & 10 & UJ & 10 & UJ & 10 & UJ & 10 & $\mathrm{U}$ \\
\hline Carbon Disulfide & 45 & UJ & 23 & UJ & 5 & UJ & 5 & UJ & 5 & UJ & 5 & UJ & 5 & $\mathrm{U}$ \\
\hline 1,1-Dichloroethene & 45 & UJ & 23 & UJ & 5 & UJ & 5 & UJ & 5 & UJ & 5 & UJ & 5 & $\mathrm{U}$ \\
\hline 1,1-Dichloroethane & 45 & UJ & 23 & UJ & 5 & UJ & 5 & UJ & 5 & UJ & 5 & UJ & 5 & $\mathbf{U}$ \\
\hline 1,2-Dichloroethene (total) & 45 & UJ & 23 & UJ & 5 & UJ & 5 & UJ & 5 & UJ & 5 & UJ & 5 & $\mathrm{U}$ \\
\hline Chloroform & 45 & UJ & 23 & UJ & 5 & UJ & 5 & UJ & 5 & UJ & 5 & UJ & 5 & $\mathbf{U}$ \\
\hline 1,2-Dichloroethane & 45 & UJ & 23 & UJ & 5 & UJ & 5 & UJ & 5 & UJ & 5 & UJ & 5 & $\mathbf{U}$ \\
\hline 2-Butanone & 91 & UJ & 45 & UJ & 10 & UJ & 10 & UJ & 10 & UJ & 10 & UJ & 10 & $\mathbf{U}$ \\
\hline 1,1,1-Trichloroethane & 45 & UJ & 23 & UJ & 5 & UJ & 5 & UJ & 5 & UJ & 5 & UJ & 5 & $\mathbf{U}$ \\
\hline Carbon Tetrachloride & 45 & UJ & 23 & $\mathbf{U}$ & 5 & UJ & 5 & UJ & 5 & UJ & 5 & UJ & 5 & $\mathbf{U}$ \\
\hline Bromodichloromethane & 91 & UJ & 45 & UJ & 10 & UJ & 10 & UJ & 10 & UJ & 10 & UJ & 10 & $\mathbf{U}$ \\
\hline 1,2-Dichloropropane & 45 & UJ & 23 & UJ & 5 & UJ & 5 & UJ & 5 & UJ & 5 & UJ & 5 & $\mathbf{u}$ \\
\hline
\end{tabular}




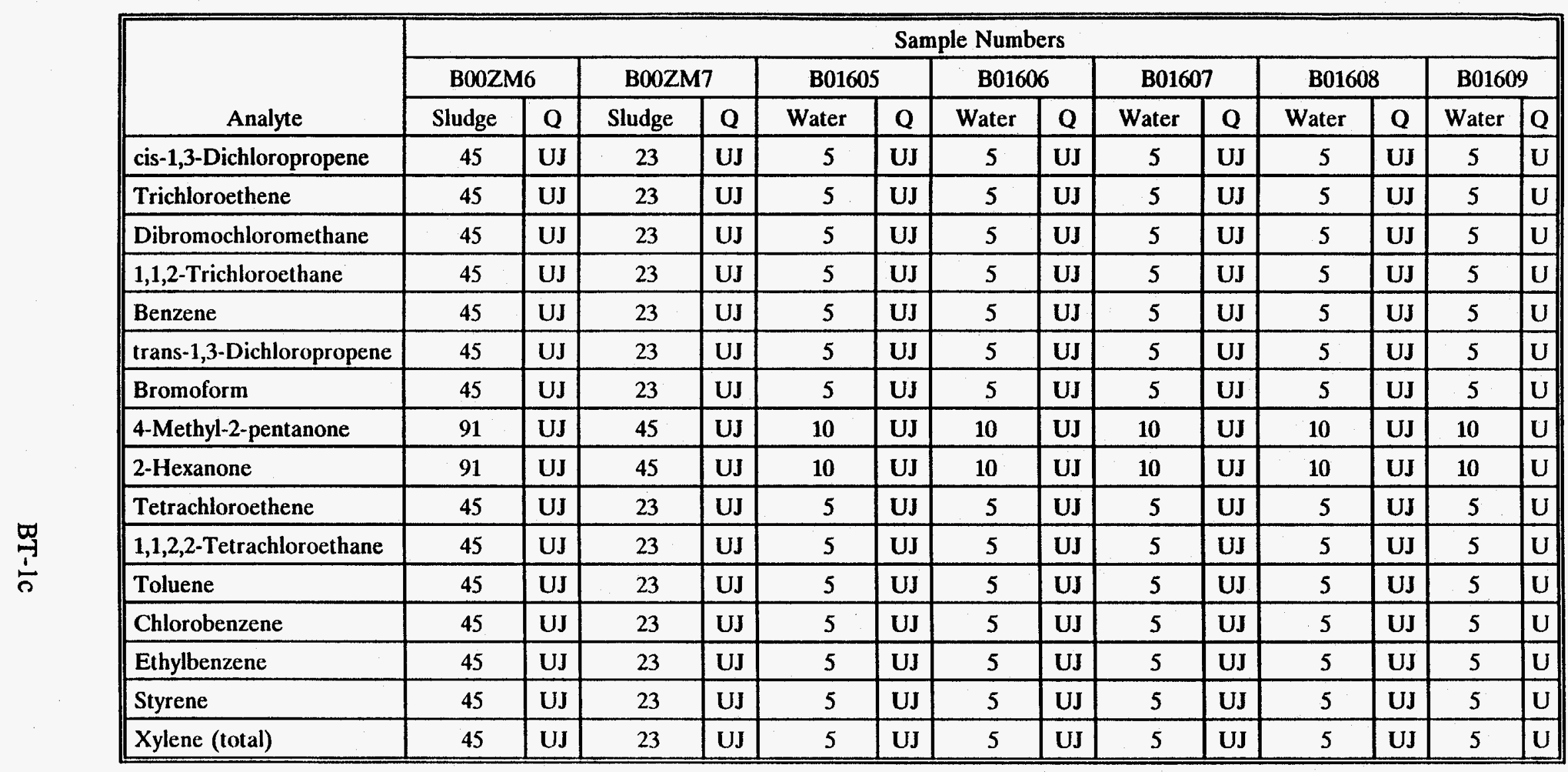

"Units in $\mathrm{mg} / \mathrm{kg}$ for sludge; $\mu \mathrm{g} / \mathrm{L}$ for water.

'Units in $\mu \mathrm{g} / \mathrm{kg}$ for sludge; $\mu \mathrm{g} / \mathrm{L}$ for water.

$\mathbf{Q}=$ Laboratory qualifier.

$\mathrm{U}=$ Below detection limit; detection limit reported.

$\mathbf{J}=$ Estimated value-quality control discrepancies occurred.

$B=$ Detected in laboratory blank.

$\mathbf{R}=$ Data deemed unusable due to significant quality control deficiency. 


\begin{tabular}{|c|c|c|c|c|c|c|c|c|c|c|c|c|c|c|}
\hline \multirow[b]{3}{*}{ Radionuclide } & \multicolumn{14}{|c|}{ Sample Numbers } \\
\hline & \multicolumn{2}{|l|}{$\mathrm{B} 00 \mathrm{ZM} 6$} & \multicolumn{2}{|l|}{ B00ZM7 } & \multicolumn{2}{|l|}{ B01605 } & \multicolumn{2}{|l|}{ B01606 } & \multicolumn{2}{|l|}{ B01607 } & \multicolumn{2}{|l|}{ B01608 } & \multicolumn{2}{|l|}{ B01609 } \\
\hline & Sludge & $\mathbf{Q}$ & Sludge & $Q$ & Water & $\mathbf{Q}$ & Water & $\mathbf{Q}$ & Water & $\mathbf{Q}$ & Water & $\mathbf{Q}$ & Water & $\mathbf{Q}$ \\
\hline Gross Beta & 18 & $\mathbf{R}$ & 21 & $\mathbf{R}$ & $\mathbf{0}$ & $\mathbf{R}$ & 0 & $\mathbf{R}$ & 21 & $\mathbf{R}$ & 22 & $\mathbf{R}$ & 1 & $\mathbf{R}$ \\
\hline Tritium & 200 & $\mathbf{R}$ & 200 & $\mathbf{R}$ & 180 & $\mathbf{R}$ & 180 & $\mathbf{R}$ & 224 & $\mathbf{R}$ & 310 & $\mathbf{R}$ & 169 & $\mathbf{R}$ \\
\hline Uranium-238 & 2.6 & $\mathbf{R}$ & 4.4 & $\mathbf{R}$ & 0.1 & $\mathbf{R}$ & 0.1 & $\mathbf{R}$ & 1.7 & $\mathbf{R}$ & 1.5 & $\mathbf{R}$ & 0.2 & $\mathbf{R}$ \\
\hline Plutonium-238 & 0.07 & $\mathbf{R}$ & 0.05 & $\mathbf{R}$ & 0.2 & $\mathbf{R}$ & 0.1 & $\mathbf{R}$ & 0.1 & $\mathbf{R}$ & 0.1 & $\mathbf{R}$ & 0.1 & $\mathbf{R}$ \\
\hline Plutonium-239/240 & 0.09 & $\mathbf{R}$ & 0.11 & $\mathbf{R}$ & 0.1 & $\mathbf{R}$ & 0.1 & $\mathbf{R}$ & 0.1 & $\mathbf{R}$ & 0.1 & $\mathbf{R}$ & 0.1 & $\mathbf{R}$ \\
\hline Plutonium-241 & 9 & $\mathbf{R}$ & 6 & $\mathbf{R}$ & 7 & $\mathbf{R}$ & 8 & $\mathbf{R}$ & 23 & $\mathbf{R}$ & 9 & $\mathbf{R}$ & 13 & $\mathbf{R}$ \\
\hline Americium-241 & 0.038 & $\mathbf{R}$ & 0.09 & $\mathbf{R}$ & 0.1 & $\mathbf{R}$ & 0.2 & $\mathbf{R}$ & 0.1 & $\mathbf{R}$ & 0.1 & $\mathbf{R}$ & 0.2 & $\mathbf{R}$ \\
\hline Potassium-40 & 7.027 & $\mathbf{J}$ & 8.053 & $\mathbf{J}$ & 133 & $\mathbf{J}$ & 253 & $\mathbf{J}$ & 174 & $\mathbf{J}$ & 69 & $\mathbf{J}$ & 215 & $\mathbf{J}$ \\
\hline Cobalt-60 & 0.48 & $\mathbf{J}$ & 1.379 & $\mathbf{J}$ & & & & & & & & & & \\
\hline Cesium-137 & 0.871 & $\mathbf{J}$ & 0.745 & $\mathrm{~J}$ & 10 & $\mathbf{J}$ & 14 & $\mathbf{J}$ & 11 & $\mathbf{J}$ & 6.3 & $\mathbf{J}$ & 12 & $\mathbf{J}$ \\
\hline Radium-226 & 0.6807 & $\mathrm{~J}$ & 1.362 & $\mathbf{J}$ & 24 & $\mathbf{J}$ & 35 & $\mathbf{J}$ & 28 & $\mathbf{J}$ & 21 & $\mathbf{J}$ & 20 & $\mathbf{J}$ \\
\hline Thorium-228 & 0.861 & $\mathbf{J}$ & 0.9115 & $\mathbf{J}$ & 19 & $\mathbf{J}$ & 23 & $\mathbf{J}$ & 22 & $\mathbf{J}$ & 13 & $\mathbf{J}$ & 18 & $\mathbf{J}$ \\
\hline Thorium-232 & 1.429 & $\mathbf{J}$ & 2.041 & $J$ & 45 & $\mathbf{J}$ & 57 & $\mathbf{J}$ & 53 & $\mathbf{J}$ & 34 & $\mathbf{J}$ & 55 & $\mathrm{~J}$ \\
\hline Europium-152 & 0.9524 & $\mathbf{J}$ & 1.122 & $\mathbf{J}$ & & & & & & & & & & \\
\hline
\end{tabular}

"Units in $\mathrm{pCi} / \mathrm{g}$ for sludge, $\mathrm{pCi} / \mathrm{L}$ for water.

$\mathbf{Q}=$ Laboratory qualifier.

$\mathrm{U}=$ Below detection limit; detection limit reported.

$R=$ Data deemed unusable due to significant quality control deficiency. 
DOE/RL-93-51, Rev. 0

Table B-3 Chemical Analysis Results for Septic Tank 1607-H-4 (page 1 of 5)

\begin{tabular}{|c|c|c|c|c|c|c|c|c|}
\hline \multirow[b]{3}{*}{ Analyte } & \multicolumn{8}{|c|}{ Sample Numbers } \\
\hline & \multicolumn{2}{|l|}{ B07206 } & \multicolumn{2}{|l|}{ B07208 } & \multicolumn{2}{|l|}{ B07207 } & \multicolumn{2}{|l|}{ B07211 } \\
\hline & Surface Soil & Q & Surface Soil & $\mathrm{Q}$ & Surface Soil & $Q$ & Surface Soil & $\mathrm{Q}$ \\
\hline \multicolumn{9}{|l|}{ Inorganic Analysis ${ }^{2}$} \\
\hline Aluminum & 5240.00 & & 4950.00 & & 3940.00 & & 8240.00 & \\
\hline Antimony & 3.20 & $\mathrm{U}$ & 3.20 & $\mathbf{U}$ & 12.10 & $\mathrm{U}$ & 3.30 & U \\
\hline Arsenic & 0.94 & B & 1.50 & B & 2.00 & $\mathrm{U}$ & 7.80 & \\
\hline Barium & 27.30 & B & 27.60 & B & 40.40 & & 226.00 & \\
\hline Beryllium & 0.14 & $\mathbf{U}$ & 0.14 & $\mathbf{U}$ & 1.00 & $\mathbf{U}$ & 0.18 & B \\
\hline Cadmium & 0.29 & $\mathbf{U}$ & 0.29 & $\mathbf{U}$ & 1.00 & $\mathbf{U}$ & 0.31 & $\mathbf{U}$ \\
\hline Calcium & 2490.00 & & 2460.00 & & 2160.00 & & 8310.00 & \\
\hline Chromium & 8.90 & & 9.40 & & 8.20 & & 19.80 & \\
\hline Cobalt & 6.90 & B & 6.50 & B & 10.10 & $\mathrm{U}$ & 8.40 & B \\
\hline Copper & 15.60 & & 15.30 & & 11.30 & & 40.20 & \\
\hline Cyanide & 0.50 & $\mathrm{U}$ & 0.49 & $\mathrm{U}$ & 1.00 & $\mathbf{U}$ & 0.52 & U \\
\hline Iron & 13800.00 & & 13200.00 & & 10500.00 & & 19800.00 & \\
\hline Lead & 3.40 & & 3.50 & & 2.70 & & 50.00 & \\
\hline Magnesium & 3730.00 & & 3580.00 & & 2960.00 & & 4440.00 & \\
\hline Manganese & 203.00 & & 187.00 & & 157.00 & & 315.00 & \\
\hline Mercury & 0.05 & $\mathrm{U}$ & 0.04 & $\mathbf{U}$ & 0.10 & $\mathbf{U}$ & 0.50 & \\
\hline Nickel & 8.40 & & 8.30 & & 8.10 & $\mathrm{U}$ & 12.80 & \\
\hline Potassium & 605.00 & B & 546.00 & B & 1010.00 & $\mathrm{U}$ & 1050.00 & \\
\hline Selenium & 0.70 & $\mathrm{U}$ & 0.76 & $\mathbf{U}$ & 1.00 & $\mathrm{U}$ & 0.80 & $\mathrm{U}$ \\
\hline Silver & 0.94 & $\mathrm{U}$ & 0.93 & $\mathrm{U}$ & 2.00 & $\mathrm{U}$ & 0.98 & $\mathrm{U}$ \\
\hline Sodium & 139.00 & B & 118.00 & B & 1010.00 & $\mathbf{U}$ & 258.00 & B \\
\hline Thallium & 0.30 & $\mathrm{U}$ & 0.32 & $\mathrm{U}$ & 2.00 & $\mathrm{U}$ & 0.34 & $\mathrm{U}$ \\
\hline Vanadium & 39.10 & & 36.00 & & 21.00 & & 37.80 & \\
\hline Zinc & 33.60 & & 33.30 & & 25.20 & & 194.00 & \\
\hline \multicolumn{9}{|l|}{ Organic Analysis $^{b}$} \\
\hline 1,1,1-Trichloroethane & 10 & $\mathrm{U}$ & 10 & $\mathrm{U}$ & 10 & $\mathrm{U}$ & 10 & $\mathbf{U}$ \\
\hline 1,1,2,2-Tetrachloroethane & 10 & $\mathrm{U}$ & 10 & $\mathrm{U}$ & 10 & $\mathrm{U}$ & 10 & $\mathbf{U}$ \\
\hline 1,1,2-Trichloroethane & 10 & $\mathrm{U}$ & 10 & $\mathrm{U}$ & 10 & $\mathbf{U}$ & 10 & $\mathbf{U}$ \\
\hline 1,1-Dichloroethane & 10 & $\mathrm{U}$ & 10 & $\mathrm{U}$ & 10 & $\mathrm{U}$ & 10 & $\mathrm{U}$ \\
\hline 1,2-Dichloroethane & 10 & $\mathrm{U}$ & 10 & $\mathbf{U}$ & 10 & $\mathrm{U}$ & 10 & $\mathbf{U}$ \\
\hline 1,2-Dichloropropane & 10 & $\mathrm{U}$ & 10 & $\mathbf{U}$ & 10 & $\mathrm{U}$ & 10 & $\mathrm{U}$ \\
\hline 2-Hexanone & 10 & $\mathrm{U}$ & 10 & $\mathbf{U}$ & 10 & $\mathrm{U}$ & 10 & $\mathbf{U}$ \\
\hline 4-Methyl-2-pentanone & 10 & $\mathrm{U}$ & 10 & $\mathrm{U}$ & 10 & $\mathrm{U}$ & 10 & $\mathrm{U}$ \\
\hline
\end{tabular}

Refer to footnotes at end of table. 
DOE/RL-93-51, Rev. 0

Table B-3 Chemical Analysis Results for Septic Tank 1607-H-4 (page 2 of 5)

\begin{tabular}{|c|c|c|c|c|c|c|c|c|}
\hline \multirow[b]{3}{*}{ Analyte } & \multicolumn{8}{|c|}{ Sample Numbers } \\
\hline & \multicolumn{2}{|l|}{ B07206 } & \multicolumn{2}{|l|}{ B07208 } & \multicolumn{2}{|l|}{ B07207 } & \multicolumn{2}{|l|}{ B07211 } \\
\hline & Surface Soil & $\mathbf{Q}$ & Surface Soil & $Q$ & Surface Soil & $\mathbf{Q}$ & Surface Soil & $\mathbf{Q}$ \\
\hline Acetone & 24 & $\mathbf{B}$ & 17 & & 6 & $\mathbf{B}$ & 23 & B \\
\hline Benzene & 10 & $\mathbf{U}$ & 10 & $\mathrm{U}$ & 10 & $\mathrm{U}$ & 10 & $\mathrm{U}$ \\
\hline Bromodichloromethane & 10 & $\mathbf{U}$ & 10 & $\mathrm{U}$ & 10 & $\mathrm{U}$ & 10 & $\mathrm{U}$ \\
\hline Bromoform & 10 & $\mathbf{U}$ & 10 & $\mathbf{U}$ & 10 & $\mathrm{U}$ & 10 & $\mathrm{U}$ \\
\hline Bromomethane & 10 & $\mathbf{U}$ & 10 & $\mathbf{U}$ & 10 & $\mathrm{U}$ & 10 & $\mathbf{U}$ \\
\hline Carbon disulfide & 10 & $\mathbf{U}$ & 10 & $\mathbf{U}$ & 10 & $\mathbf{U}$ & 2 & $\mathrm{~J}$ \\
\hline Carbon tetrachloride & 10 & $\mathrm{U}$ & 10 & $\mathbf{U}$ & 10 & $\mathrm{U}$ & 10 & $\mathbf{U}$ \\
\hline Chlorobenzene & 10 & $\mathbf{U}$ & 10 & $\mathbf{U}$ & 10 & $\mathrm{U}$ & 10 & U \\
\hline Chloroethane & 10 & $\mathrm{U}$ & 10 & $\mathrm{U}$ & 10 & $\mathrm{U}$ & 10 & $\mathrm{U}$ \\
\hline Chloroform & 10 & $\mathbf{U}$ & 10 & $\mathbf{U}$ & 10 & $\mathrm{U}$ & 10 & $\mathbf{U}$ \\
\hline Chloromethane & 10 & $U$ & 10 & $\mathrm{U}$ & 10 & $\mathrm{U}$ & 10 & $\mathrm{U}$ \\
\hline Dibromochloromethane & 10 & $\mathbf{U}$ & 10 & $\mathrm{U}$ & 10 & $\mathrm{U}$ & 10 & $\mathrm{U}$ \\
\hline Ethylbenzene & 10 & $\mathbf{U}$ & 10 & $\mathrm{U}$ & 10 & $\mathbf{U}$ & 10 & $\mathrm{U}$ \\
\hline Methylene chloride & 10 & $\mathbf{U}$ & 10 & $\mathrm{U}$ & 10 & $\mathbf{U}$ & 6 & $\mathrm{~J}$ \\
\hline Styrene & 10 & $\mathrm{U}$ & 10 & $\mathrm{U}$ & 10 & $\mathrm{U}$ & 10 & $\mathbf{U}$ \\
\hline Tetrachloroethene & 10 & $\mathrm{U}$ & 10 & $\mathrm{U}$ & 10 & $\mathrm{U}$ & 10 & $\mathrm{U}$ \\
\hline Toluene & 10 & $\mathrm{U}$ & 10 & U & 10 & $\mathbf{U}$ & 4 & $\mathrm{~J}$ \\
\hline Trichloroethene & 10 & $\mathrm{U}$ & 10 & $\mathrm{U}$ & 10 & $\mathbf{U}$ & 10 & $\mathrm{U}$ \\
\hline Vinyl chloride & 10 & $\mathrm{U}$ & 10 & $U$ & 10 & $\mathrm{U}$ & 10 & $\mathrm{U}$ \\
\hline Xylenes (total) & 10 & $\mathrm{U}$ & 10 & $\mathrm{U}$ & 10 & $\mathrm{U}$ & 10 & $\mathrm{U}$ \\
\hline cis-1,3-Dichloropropene & 10 & $\mathrm{U}$ & 10 & $U$ & 10 & $\mathrm{U}$ & 10 & $\mathrm{U}$ \\
\hline trans-1,3-Dichloropropene & 10 & $\mathrm{U}$ & 10 & U & 10 & $\mathrm{U}$ & 10 & $\mathrm{U}$ \\
\hline \multicolumn{9}{|l|}{ Semivolatile Organic Analysis ${ }^{b}$} \\
\hline 2,4-Dinitrotoluene & 330 & $\mathrm{U}$ & 330 & $\mathrm{U}$ & 340 & $\mathrm{U}$ & 680 & $\mathrm{U}$ \\
\hline 2,6-Dinitrotoluene & 330 & $\mathrm{U}$ & 330 & $\mathrm{U}$ & 340 & $\mathrm{U}$ & 680 & $\mathrm{U}$ \\
\hline 3,3-Dichlorobenzidine & 330 & $\mathrm{U}$ & 330 & $\mathrm{U}$ & 340 & $\mathrm{U}$ & 680 & $\mathrm{U}$ \\
\hline 4,6-Dinitro-2-methylphenol & 790 & $\mathrm{U}$ & 800 & $\mathrm{U}$ & 840 & $\mathrm{U}$ & 1600 & $\mathrm{U}$ \\
\hline 4-Bromophenylphenyl ether & 330 & $\mathbf{U}$ & 330 & $\mathrm{U}$ & 340 & $\mathrm{U}$ & 680 & $\mathrm{U}$ \\
\hline 4-Chloropherylphenyl ether & 330 & $\mathrm{U}$ & 330 & $\mathbf{U}$ & 340 & $\mathbf{U}$ & 680 & $\mathrm{U}$ \\
\hline 4-Nitroaniline & 790 & $\mathrm{U}$ & 800 & $\mathrm{U}$ & 840 & $\mathrm{U}$ & 1600 & $\mathrm{U}$ \\
\hline 4-Nitrophenol & 790 & $\mathrm{U}$ & 800 & $\mathrm{U}$ & 840 & $\mathbf{U}$ & 1600 & $\mathrm{U}$ \\
\hline Carbazole & 330 & $\mathrm{U}$ & 330 & $\mathrm{U}$ & 340 & $\mathrm{U}$ & 150 & $\mathrm{~J}$ \\
\hline Anthracene & 330 & $\mathrm{U}$ & 330 & $\mathrm{U}$ & 340 & $\mathbf{U}$ & 320 & $\mathrm{~J}$ \\
\hline Benzo(a)anthracene & 330 & $\mathrm{U}$ & 330 & $U$ & 340 & $\mathrm{U}$ & 1800 & \\
\hline
\end{tabular}

Refer to footnotes at end of table. 
DOE/RL-93-51, Rev. 0

Table B-3 Chemical Analysis Results for Septic Tank 1607-H-4 (page 3 of 5)

\begin{tabular}{|c|c|c|c|c|c|c|c|c|}
\hline \multirow[b]{3}{*}{ Analyte } & \multicolumn{8}{|c|}{ Sample Numbers } \\
\hline & \multicolumn{2}{|l|}{ B07206 } & \multicolumn{2}{|l|}{ B07208 } & \multicolumn{2}{|l|}{ B07207 } & \multicolumn{2}{|l|}{ B07211 } \\
\hline & Surface Soil & $\mathbf{Q}$ & Surface Soil & $\mathrm{Q}$ & Surface Soil & $Q$ & Surface Soil & $\mathbf{Q}$ \\
\hline Benzo(a)pyrene & 330 & $\mathbf{U}$ & 330 & $\mathrm{U}$ & 340 & $\mathrm{U}$ & 940 & \\
\hline Benzo(b)fluoranthene & 330 & $\mathbf{U}$ & 330 & $\mathbf{U}$ & 340 & $\mathrm{U}$ & 2400 & \\
\hline Benzo(ghi)perylene & 330 & $\mathbf{U}$ & 330 & $\mathbf{U}$ & 340 & $\mathbf{U}$ & 460 & $\mathbf{J}$ \\
\hline Benzo(k)fluoranthene & 330 & $\mathrm{U}$ & 330 & $\mathbf{U}$ & 340 & $\mathbf{U}$ & 680 & $\mathbf{U}$ \\
\hline Bis(2-ethylhexyl)phthalate & 330 & $\mathbf{U}$ & 330 & $\mathbf{U}$ & 45 & B & 680 & $\mathbf{U}$ \\
\hline Butylbenzylphthalate & 330 & $\mathbf{U}$ & 330 & $\mathbf{U}$ & 340 & $\mathbf{U}$ & 680 & $\mathbf{U}$ \\
\hline Chrysene & 330 & $\mathbf{U}$ & 330 & $\mathbf{U}$ & 340 & $\mathbf{U}$ & 920 & \\
\hline Di-n-butylphthalate & 330 & $\mathbf{U}$ & 330 & $\mathbf{U}$ & 180 & B & 680 & $\mathbf{U}$ \\
\hline Di-n-octylphthalate & 330 & $\mathbf{U}$ & 330 & $\mathrm{U}$ & 340 & $\mathbf{U}$ & 680 & $\mathbf{U}$ \\
\hline Dibenz $[\mathrm{a}, \mathrm{h}]$ anthracene & 330 & $\mathbf{U}$ & 330 & $\mathbf{U}$ & 340 & $\mathrm{U}$ & 680 & $\mathbf{U}$ \\
\hline Dibenzofuran & 330 & $\mathbf{U}$ & 330 & $\mathbf{U}$ & 340 & $\mathbf{U}$ & 680 & $\mathbf{U}$ \\
\hline Diethyl phthalate & 330 & $\mathbf{U}$ & 330 & $\mathrm{U}$ & 340 & $\mathrm{U}$ & 680 & $\mathrm{U}$ \\
\hline Fluoranthene & 330 & $\mathbf{U}$ & 330 & $\mathbf{U}$ & 340 & $\mathrm{U}$ & 2900 & \\
\hline Fluorene & 330 & $\mathbf{U}$ & 330 & $\mathrm{U}$ & 340 & $\mathrm{U}$ & 110 & $\mathbf{J}$ \\
\hline Hexachlorobenzene & 330 & $\mathbf{U}$ & 330 & $\mathbf{U}$ & 340 & $\mathrm{U}$ & 680 & $\mathbf{U}$ \\
\hline Indeno(1,2,3-cd)pyrene & 330 & $\mathbf{U}$ & 330 & $\mathrm{U}$ & 340 & $\mathbf{U}$ & 480 & I \\
\hline N-Nitrosodiphenylamine & 330 & $\mathbf{U}$ & 330 & $\mathrm{U}$ & 340 & $\mathrm{U}$ & 680 & $\mathbf{U}$ \\
\hline Pentachlorophenol & 790 & $\mathrm{U}$ & 800 & $\mathbf{U}$ & 33 & $\mathbf{J}$ & 1600 & $\mathbf{U}$ \\
\hline Phenanthrene & 330 & $\mathrm{U}$ & 330 & $\mathrm{U}$ & 340 & $\mathrm{U}$ & 1600 & \\
\hline Pyrene & 330 & $\mathbf{U}$ & 330 & $\mathbf{U}$ & 340 & $\mathrm{U}$ & 2700 & \\
\hline 1,2,4-Trichlorobenzene & 330 & $\mathbf{U}$ & 330 & $\mathbf{U}$ & 340 & $\mathrm{U}$ & 680 & $\mathrm{U}$ \\
\hline 1,2-Dichlorobenzene & 330 & $\mathrm{U}$ & 330 & $\mathbf{U}$ & 340 & $\mathrm{U}$ & 680 & $\mathrm{U}$ \\
\hline 1,3-Dichlorobenzene & 330 & $\mathbf{U}$ & 330 & $\mathbf{U}$ & 340 & $\mathrm{U}$ & 680 & $\mathrm{U}$ \\
\hline 1,4-Dichlorobenzene & 330 & $\mathbf{U}$ & 330 & $\mathbf{U}$ & 340 & $\mathrm{U}$ & 680 & $\mathrm{U}$ \\
\hline 2,4,5-Trichlorophenol & 790 & $\mathrm{U}$ & 800 & $\mathrm{U}$ & 840 & $\mathrm{U}$ & 1600 & $\mathbf{U}$ \\
\hline 2,4,6-Trichlorophenol & 330 & $\mathrm{U}$ & 330 & $\mathrm{U}$ & 340 & $\mathbf{U}$ & 680 & $\mathbf{U}$ \\
\hline 24-Dichlorophenol & 330 & $\mathbf{U}$ & 330 & $\mathbf{U}$ & 340 & $\mathrm{U}$ & 680 & $\mathbf{U}$ \\
\hline 2,4-Dimethylphenol & 330 & $\mathrm{U}$ & 330 & $\mathbf{U}$ & 340 & $\mathrm{U}$ & 680 & $\mathbf{U}$ \\
\hline 2,4-Dinitrophenol & 790 & $\mathrm{U}$ & 800 & $\mathbf{U}$ & 840 & $\mathbf{U}$ & 1600 & $\mathbf{U}$ \\
\hline 2-Chloronaphthalene & 330 & $\mathrm{U}$ & 330 & $\mathrm{U}$ & 340 & $\mathrm{U}$ & 680 & $\mathbf{U}$ \\
\hline 2-Chlorophenol & 330 & $\mathrm{U}$ & 330 & $\mathrm{U}$ & 340 & $\mathrm{U}$ & 680 & $\mathrm{U}$ \\
\hline 2-Methylnaphthalene & 330 & $\mathbf{U}$ & 330 & $\mathrm{U}$ & 340 & $\mathrm{U}$ & 680 & $\mathrm{U}$ \\
\hline 2-Methylphenol & 330 & $\mathbf{U}$ & 330 & $\mathbf{U}$ & 340 & $\mathbf{U}$ & 680 & $\mathbf{U}$ \\
\hline 2-Nitroaniline & 790 & $\mathrm{U}$ & 800 & $\mathrm{U}$ & 840 & $\mathbf{U}$ & 1600 & $\mathbf{U}$ \\
\hline
\end{tabular}

Refer to footnotes at end of table. 
Table B-3 Chemical Analysis Results for Septic Tank 1607-H-4 (page 4 of 5)

\begin{tabular}{|c|c|c|c|c|c|c|c|c|}
\hline \multirow[b]{3}{*}{ Analyte } & \multicolumn{8}{|c|}{ Sample Numbers } \\
\hline & \multicolumn{2}{|l|}{ B07206 } & \multicolumn{2}{|l|}{ B07208 } & \multicolumn{2}{|l|}{ B07207 } & \multicolumn{2}{|l|}{ B07211 } \\
\hline & Surface Soil & $Q$ & Surface Soil & $\mathbf{Q}$ & Surface Soil & $Q$ & Surface Soil & $Q$ \\
\hline 2-Nitrophenol & 330 & $\mathrm{U}$ & 330 & $\mathbf{U}$ & 340 & $\mathrm{U}$ & 680 & $\mathrm{U}$ \\
\hline 3-Nitroaniline & 790 & $U$ & 800 & $\mathbf{U}$ & 840 & $U$ & 1600 & $\mathrm{U}$ \\
\hline 4-Chloro-3-methylphenol & 330 & $\mathrm{U}$ & 330 & $\mathbf{U}$ & 340 & $\mathrm{U}$ & 680 & $\mathrm{U}$ \\
\hline 4-Chloroaniline & 330 & $\mathrm{U}$ & 330 & $\mathbf{U}$ & 340 & $\mathbf{U}$ & 680 & $\mathrm{U}$ \\
\hline 4-Methylphenol & 330 & $\mathrm{U}$ & 330 & $\mathbf{U}$ & 340 & $\mathbf{U}$ & 680 & $\mathrm{U}$ \\
\hline Acenaphthene & 330 & $\mathbf{U}$ & 330 & $\mathbf{U}$ & 340 & $\mathrm{U}$ & 130 & $\mathbf{J}$ \\
\hline Acenaphthylene & 330 & $\mathbf{U}$ & 330 & $\mathbf{U}$ & 340 & $\mathrm{U}$ & 680 & $\mathbf{U}$ \\
\hline Bis(2-Chloroethoxy)methane & 330 & $\mathrm{U}$ & 330 & $\mathbf{U}$ & 340 & $\mathbf{U}$ & 680 & $\mathbf{U}$ \\
\hline Bis(2-Chloroethyl)ether & 330 & $\mathrm{U}$ & 330 & $\mathbf{U}$ & 340 & $\mathbf{U}$ & 680 & $\mathbf{U}$ \\
\hline Dimethyl phthalate & 330 & $\mathrm{U}$ & 330 & $\mathrm{U}$ & 340 & $\mathrm{U}$ & 680 & $\mathrm{U}$ \\
\hline Hexachlorobutadiene & 330 & $\mathrm{U}$ & 330 & $\mathbf{U}$ & 340 & $\mathbf{U}$ & 680 & $\mathbf{U}$ \\
\hline Hexachlorocyclopentadiene & 330 & $\mathrm{U}$ & 330 & $\mathbf{U}$ & 340 & $\mathbf{U}$ & 680 & $\mathbf{U}$ \\
\hline Hexachloroethane & 330 & $\mathbf{U}$ & 330 & $\mathbf{U}$ & 340 & $\mathbf{U}$ & 680 & $\mathrm{U}$ \\
\hline Isophorone & 330 & $\mathrm{U}$ & 330 & $\mathbf{U}$ & 340 & $\mathrm{U}$ & 680 & $\mathbf{U}$ \\
\hline N-Nitroso-di-n-dipropylamine & 330 & $\mathrm{U}$ & 330 & $\mathbf{U}$ & 340 & $\mathrm{U}$ & 680 & $\mathbf{U}$ \\
\hline Naphthalene & 330 & $\mathrm{U}$ & 330 & $\mathbf{U}$ & 340 & $\mathrm{U}$ & 680 & $\mathbf{U}$ \\
\hline Nitrobenzene & 330 & $\mathrm{U}$ & 330 & $\mathbf{U}$ & 340 & $\mathbf{U}$ & 680 & $\mathbf{U}$ \\
\hline Phenol & 330 & $\mathrm{U}$ & 330 & $\mathrm{U}$ & 220 & $\mathrm{~J}$ & 680 & $\mathbf{U}$ \\
\hline \multicolumn{9}{|l|}{ Pesticide Analysis ${ }^{b}$} \\
\hline $4,4^{\prime}-\mathrm{DDD}$ & 3.3 & $\mathrm{U}$ & 3.2 & $\mathbf{U}$ & 3.4 & $\mathrm{U}$ & 110.0 & \\
\hline $4,4^{\prime}-\mathrm{DDE}$ & 3.3 & $\mathrm{U}$ & 3.2 & $\mathrm{U}$ & 3.4 & $\mathrm{U}$ & 12.0 & \\
\hline $4,4^{\prime}-\mathrm{DDT}$ & 3.3 & $\mathbf{U}$ & 3.2 & $\mathbf{U}$ & 3.4 & $\mathrm{U}$ & 3.3 & $\mathrm{U}$ \\
\hline Aldrin & 1.7 & $\mathbf{U}$ & 1.7 & $U$ & 1.7 & $U$ & 1.7 & $U$ \\
\hline Alpha-BHC & 1.7 & $\mathrm{U}$ & 1.7 & $\mathrm{U}$ & 1.7 & $\mathrm{U}$ & 1.7 & $\mathrm{U}$ \\
\hline Aroclor-1016 & 33.0 & $\mathrm{U}$ & 32.0 & $\mathrm{U}$ & 34.0 & $\mathrm{U}$ & 33.0 & $\mathrm{U}$ \\
\hline Aroclor- 1221 & 66.0 & $\mathrm{U}$ & 66.0 & $\mathrm{U}$ & 67.0 & $\mathrm{U}$ & 68.0 & $\mathrm{U}$ \\
\hline Aroclor-1232 & 33.0 & $\mathrm{U}$ & 32.0 & $\mathrm{U}$ & 34.0 & $\mathrm{U}$ & 33.0 & $\mathrm{U}$ \\
\hline Aroclor-1242 & 33.0 & $\mathrm{U}$ & 32.0 & $\mathbf{U}$ & 34.0 & $\mathbf{U}$ & 33.0 & $\mathbf{U}$ \\
\hline Aroclor-1248 & 33.0 & $\mathrm{U}$ & 32.0 & $\mathrm{U}$ & 34.0 & $\mathrm{U}$ & 33.0 & $\mathrm{U}$ \\
\hline Aroclor- 1254 & 33.0 & $\mathrm{U}$ & 32.0 & $\mathrm{U}$ & 34.0 & $\mathrm{U}$ & 33.0 & $\mathrm{U}$ \\
\hline Aroclor -1260 & 33.0 & $\mathrm{U}$ & 32.0 & $\mathrm{U}$ & 34.0 & $\mathbf{U}$ & 33.0 & $\mathbf{U}$ \\
\hline Beta-BHC & 1.7 & $\mathrm{U}$ & 1.7 & $\mathrm{U}$ & 1.7 & $\mathrm{U}$ & 1.7 & $\mathrm{U}$ \\
\hline Delta-BHC & 1.7 & $\mathrm{U}$ & 1.7 & $\mathrm{U}$ & 1.7 & $\mathrm{U}$ & 1.7 & $\mathrm{U}$ \\
\hline Dieldrin & 3.3 & $U$ & 3.2 & $U$ & 3.4 & $\mathbf{U}$ & 3.3 & $\mathrm{U}$ \\
\hline
\end{tabular}

Refer to footnotes at end of table. 
DOE/RL-93-51, Rev. 0

Table B-3 Chemical Analysis Results for Septic Tank 1607-H-4 (page 5 of 5)

\begin{tabular}{||l|r|r|r|r|r|r|r|r||}
\hline \multirow{2}{*}{\multicolumn{1}{c|}{ Analyte }} & \multicolumn{9}{c|}{ Sample Numbers } \\
\cline { 2 - 11 } & \multicolumn{2}{|c|}{ B07206 } & \multicolumn{2}{c|}{ B07208 } & \multicolumn{2}{c|}{ B07207 } & \multicolumn{2}{c|}{ B07211 } \\
\cline { 2 - 11 } & Surface Soil & $\mathrm{O}$ & Surface Soil & $\mathrm{O}$ & Surface Soil & $\mathrm{O}$ & Surface Soil & $\mathrm{Q}$ \\
\hline Endosulfan I & 1.7 & $\mathrm{U}$ & 1.7 & $\mathrm{U}$ & 1.7 & $\mathrm{U}$ & 1.7 & $\mathrm{U}$ \\
\hline Endosulfan II & 3.3 & $\mathrm{U}$ & 3.2 & $\mathrm{U}$ & 3.4 & $\mathrm{U}$ & 3.3 & $\mathrm{U}$ \\
\hline Endosulfan sulfate & 3.3 & $\mathrm{U}$ & 3.2 & $\mathrm{U}$ & 3.4 & $\mathrm{U}$ & 3.3 & $\mathrm{U}$ \\
\hline Endrin & 3.3 & $\mathrm{U}$ & 3.2 & $\mathrm{U}$ & 3.4 & $\mathrm{U}$ & 3.3 & $\mathrm{U}$ \\
\hline Endrin Aldehyde & 3.3 & $\mathrm{U}$ & 3.2 & $\mathrm{U}$ & 3.4 & $\mathrm{U}$ & 3.3 & $\mathrm{U}$ \\
\hline Endrin ketone & 3.3 & $\mathrm{U}$ & 3.2 & $\mathrm{U}$ & 3.4 & $\mathrm{U}$ & 3.3 & $\mathrm{U}$ \\
\hline Gamma-BHC (Lindane) & 1.7 & $\mathrm{U}$ & 1.7 & $\mathrm{U}$ & 1.7 & $\mathrm{U}$ & 1.7 & $\mathrm{U}$ \\
\hline Heptachlor & 1.7 & $\mathrm{U}$ & 1.7 & $\mathrm{U}$ & 1.7 & $\mathrm{U}$ & 1.7 & $\mathrm{U}$ \\
\hline Heptachlor epoxide & 1.7 & $\mathrm{U}$ & 1.7 & $\mathrm{U}$ & 1.7 & $\mathrm{U}$ & 1.7 & $\mathrm{U}$ \\
\hline Methoxychlor & 17.0 & $\mathrm{U}$ & 17.0 & $\mathrm{U}$ & 17.0 & $\mathrm{U}$ & 17.0 & $\mathrm{U}$ \\
\hline Toxaphene & 170.0 & $\mathrm{U}$ & 170.0 & $\mathrm{U}$ & 170.0 & $\mathrm{U}$ & 170.0 & $\mathrm{U}$ \\
\hline alpha-Chlordane & 1.7 & $\mathrm{U}$ & 1.7 & $\mathrm{U}$ & 1.7 & $\mathrm{U}$ & 1.7 & $\mathrm{U}$ \\
\hline gamma-Chlordane & 1.7 & $\mathrm{U}$ & 1.7 & $\mathrm{U}$ & 1.7 & $\mathrm{U}$ & 18.0 & \\
\hline \hline
\end{tabular}

2Units in $\mathrm{mg} / \mathrm{kg}$.

${ }^{b}$ Units in $\mu \mathrm{g} / \mathrm{kg}$.

$\mathrm{Q}=$ Laboratory qualifier.

$\mathrm{U}=$ Below detection limit; detection limit reported.

$\mathbf{J}=$ Estimated value-quality control discrepancies occurred.

$B=$ Detected in laboratory blank. 
DOE/RL-93-51, Rev. 0

Table B-4 Radionuclide Analysis Results for Septic Tank 1607-H-4

\begin{tabular}{|c|c|c|c|c|c|c|}
\hline \multirow[b]{3}{*}{ Radionuclide $^{\mathrm{a}}$} & \multicolumn{6}{|c|}{ Sample Numbers } \\
\hline & \multicolumn{2}{|l|}{ B07206 } & \multicolumn{2}{|l|}{ B07208 } & \multicolumn{2}{|l|}{ B07211 } \\
\hline & Surface Soil & Q & Surface Soil & Q & Surface Soil & Q \\
\hline Gross Alpha & 8.8 & $\mathrm{~J}$ & 7.6 & $\mathrm{~J}$ & 4.7 & $\mathrm{U}$ \\
\hline Gross Beta & 17 & & 15 & & 17 & \\
\hline Uranium-233/234 & 0.57 & & 0.41 & & 0.62 & \\
\hline Uranium-235 & 0.058 & $\mathrm{U}$ & 0.026 & $\mathrm{U}$ & 0 & $\mathrm{U}$ \\
\hline Uranium-238 & 0.48 & & 0.44 & & 0.31 & \\
\hline Plutonium-238 & 0 & $\mathrm{U}$ & -0.001 & $\mathrm{U}$ & 0.011 & $\mathrm{U}$ \\
\hline Plutonium-239/240 & 0.005 & $\mathrm{U}$ & 0.003 & $\mathrm{U}$ & 0.006 & $\mathrm{U}$ \\
\hline Americium-241 & -0.005 & $\mathrm{U}$ & -0.003 & $\mathrm{U}$ & -0.004 & $\mathrm{U}$ \\
\hline Strontium-90 & -0.042 & $\mathrm{U}$ & 0.23 & $\mathrm{U}$ & 0 & $\mathrm{U}$ \\
\hline Potassium-40 & 12 & & 14 & & 8.3 & \\
\hline Cobalt- 60 & 0 & $\mathrm{U}$ & 0 & $\mathrm{U}$ & 0 & $\mathrm{U}$ \\
\hline Cesium-137 & 0 & $\mathrm{U}$ & 0 & $\mathrm{U}$ & 0.67 & \\
\hline Radium-226 & 0.45 & & 0.44 & & 0.37 & \\
\hline Thorium-228 & 0.54 & & 0.56 & & 0.40 & \\
\hline Thorium-232 & 0.51 & & 0.62 & & 0.44 & \\
\hline Europium-152 & 0 & $\mathrm{U}$ & 0 & $\mathrm{U}$ & 1.2 & \\
\hline Europium-154 & 0 & $\mathrm{U}$ & 0 & $\mathrm{U}$ & 0 & $\mathrm{U}$ \\
\hline
\end{tabular}

${ }^{\mathrm{a}} \mathrm{Units}$ in $\mathrm{pCi} / \mathrm{g}$.

$\mathrm{Q}=$ Laboratory qualifier.

$\mathrm{U}=$ Below detection limit; detection limit reported.

$\mathrm{J}=$ Estimated value-quality control discrepancies occurred. 


\begin{tabular}{|c|c|c|c|c|c|c|c|c|c|c|c|c|c|c|c|c|}
\hline \multirow[b]{3}{*}{ Analyte" } & \multicolumn{16}{|c|}{ Sample Numbers } \\
\hline & \multicolumn{2}{|l|}{ B01855 } & \multicolumn{2}{|l|}{ B018S6 } & \multicolumn{2}{|l|}{ B018S7 } & \multicolumn{2}{|l|}{ B018S8 } & \multicolumn{2}{|l|}{ B018S9 } & \multicolumn{2}{|l|}{ B018T0 } & \multicolumn{2}{|l|}{ B018T1 } & \multicolumn{2}{|l|}{ B018T2 } \\
\hline & Soil & $\mathbf{Q}$ & Soil & $Q$ & Soil & $\mathbf{Q}$ & Soil & $\mathbf{Q}$ & Soil & $\mathbf{Q}$ & Soil & $\mathbf{Q}$ & Soil & $\mathbf{Q}$ & Soil & $Q$ \\
\hline Aroclor-1221 & 7 & $\mathrm{U}$ & 7 & $\mathbf{U}$ & 7 & $\mathbf{U}$ & 39 & $\mathbf{U}$ & 7 & $\mathbf{U}$ & 7 & $\mathbf{U}$ & 7 & $\mathbf{U}$ & 7 & $\mathbf{U}$ \\
\hline Aroclor-1232 & 7 & $\mathrm{U}$ & 7 & $\mathbf{U}$ & 7 & $\mathbf{U}$ & 20 & $\mathbf{U}$ & 7 & $\mathbf{U}$ & 7 & $\mathbf{U}$ & 7 & $\mathbf{U}$ & 7 & $\mathbf{U}$ \\
\hline Aroclor-1254 & 7 & $\mathbf{U}$ & 7 & $\mathbf{U}$ & 7 & $\mathbf{J}$ & 350 & & 7 & $\mathbf{U}$ & 32 & $\mathbf{J}$ & 7 & $\mathbf{U}$ & 7 & $\mathbf{U}$ \\
\hline Aroclor -1260 & 1200 & $\mathbf{J}$ & 770 & $\mathbf{J}$ & 630 & $\mathbf{J}$ & 20 & $\mathbf{U}$ & 7 & U & -- & $\mathbf{E}$ & 7 & $\mathbf{u}$ & 7 & $\mathbf{U}$ \\
\hline
\end{tabular}

All values in $\mu \mathrm{g} / \mathrm{Kg}$

$\mathbf{Q}=$ Laboratory qualifier.

$\mathrm{U}=$ Below detection limit; detection limit reported.

$\mathbf{J}=$ Estimated value-quality control discrepancies occurred.

$\mathrm{E}=$ Error in analyzing sample. 
DOE/RL-93-51, Rev. 0

\section{DISTRIBUTION}

Number of Copies

$\underline{\text { Onsite }}$

31

U.S. Department of Energy, Richland Operations

J. K. Erickson (30)

A5-19

Public Reading Room

A1-65

1

Pacific Northwest Laboratory

Hanford Technical Library

P8-55

30

Westinghouse Hanford Company

L. D. Arnold

B2-35

R. L. Biggerstaff (11)

H6-02

P. J. Mackey

B3-06

EPIC (7)

H6-08

ERC (G. Fitzgibbon)

H6-07

ERE (F. Stone) (2)

H6-01

ERE Project File

H6-08

ER Program Office

H6-27

IRA (3)

H4-17

Resource Center

N3-05 